


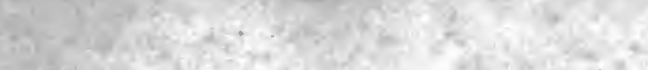

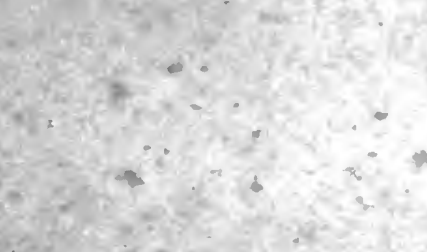

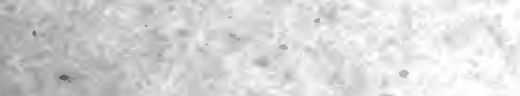

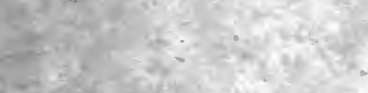

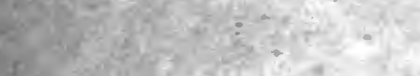

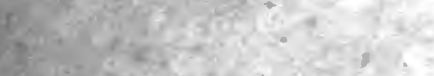

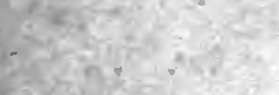

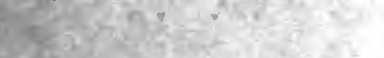

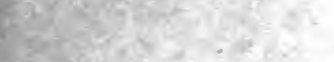

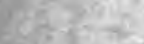

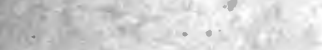





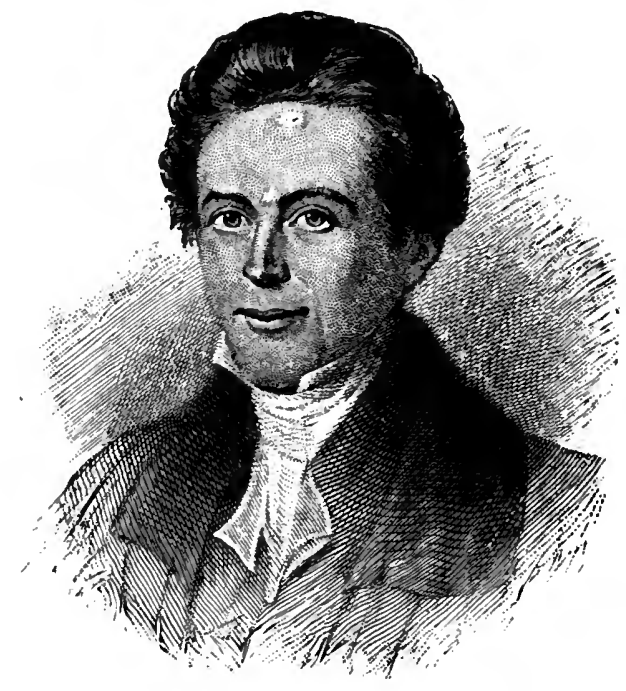




\section{THE LIFE}

OB

\section{ALEXANDER DUFF, D.D., LL.D.}

BY

GEORGE SMITH, C.I.E., LI.D.,

AUTHOR OF "THE LIFE OF JOHN WILSON, D.D., F.R.s.,"

FELLOW OF THE ROYAL GEOGRAPHIOAL AND STATISTICAL

SOCIETIES, ETO.

WITH AN INTRODUCTION BY WM. M. TAYLOR, D.D.

IN TWO VOLUMES.

With Portraits by Jeens.

VOL. I.

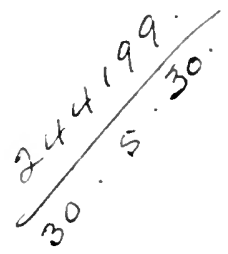

TORONTO :

W I L L I A M B R I G G S,

78 \& 80 KiNo StRKKT EAST.

MONTREAL : C. W. COATES. | HALIFAX: S. F. HUESTIS. 
Entered according to the Act of the Parliament of Canada in the year one thonsand eight hundred and eighty-two, by the Rev. Winuram BrIGgs, in the Office of the Minister of Agriculture, Ottawa. 


\section{INTRODUCTORY NOTE.}

A FRIEND speaking to me of the great pleasure and profit which he had derived from reading the Life of the Rev. A. Dufr, D.D., recently published, and stating at the same time that every minister ought to read the story of this wonderful Missionary, I said to him, "Why not let the Book Room publish an edition and present a copy to each of the ministers ?" This remark, made in the course of conversation, and with some degree of playfulness, bore fruit, and the enquiry was made next day as to the cost of carrying it out. The idea impressed itself in a manner scarcely contemplated when suggested, and that question has been answered in the edition which is now prepared for the express purpose of placing a copy of the Life of this truly devoted servant of Christ in the hands of every minister throughout the entire Connexion.

The study of such a life of Christian consecration and moral heroism, as that of Dr. DUFF, cannot fail to quicken in the minds of all the readers of this volume a warmer sympathy with the grandest of all causes-the cause of Christian Missions, which has been from the very beginning the crown and glory of Methodism-and to beget a more ardent desire to bring the world to Jesus. With the accomplishment of this result the purpose of the donor of this book will be fully attained.

\section{WILLIAM BRIGGS,}

Methodist Book and Publishing House. 


\title{
THE PEOPLES OF INDIA
}

\author{
IB INSCRIBED
}

\section{THIS LIFE OF THE CHRISTIAN MISSIONARY}

WHOSE IATEST PUBLISHED WORDS WERE THESE:

" WHEREVRR I WANDER, WHEREVER I STAY, MY HEART IS IN INDIA, IN DEEP SYMPATHY WITH ITS MULTITUDINOUS INHABITANTS, AND IN EARNEST LONGINGS FOR THEIR HIGHEST WELFARE IN TIME AND RN ETERNTTY." 
THis volume tells the story of the earlier half of Dr. Duff's life of nearly seventy-two years. Of the Scottish Mission to India, which will see its jubilee reached at the close of this year, the history is brought down to 1843. The acknowledgment of the assistance of friends, which the author has not been able to make in the text, he hopes adequately to express in the Preface to the whole work, when the second volume shall appear.

The Rev. Principal Harper, D.D. and the Rev. George Lewis have been removed by death as the sheets have passed through the press.

Serampore Houge, Merchibton,

Edingurge, 28th April, 1879. 


\section{CONTENTS.}

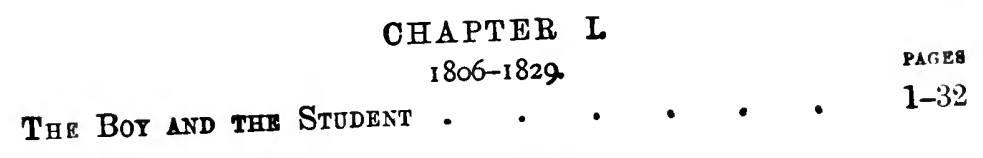

CHAPTER II.

1829.

The First Missionart of the Church of Scothand - 33-64 CHAPTER III. I830.

. . . . $\quad 65-85$

CHAPTER IV.

1830.

Calcutta as it was

$$
\underset{\text { 1830-1831. }}{\text { CHAPTER }} \nabla
$$

The Mine Prepared

CHAPTER VI.

$$
\text { 1831-1833. }
$$

The First Explosion and the Four Converts • . 137-177

CHAPTER VII.

$$
\text { 1833-1835. }
$$

The Renaissance in India - The Evglish Language $178-205$ aNd The Church

CHAPTER VIII.

$$
\text { 1833-1835. }
$$

The Renaissance in India-Science and Letters • 206-232 
CHAPTER IX.

$$
\text { I832-I } 835 \text {. }
$$

Work for Europeans, Eurasians and Native Christians 233-270

CHAPTER $\mathbf{X}$.

1835 .

The Infahid aNd the Orator

CHAPTER XI.

$$
\text { I } 835^{-1} 836 \text {. }
$$

Dr. Duff Organizing

CHAPTER XII.

$$
\text { 1837-I } 839 \text {. }
$$

Fishers of Men

CHA PTER XIII.

$$
\text { I839-I840. }
$$

Egypt-SinaI-Bombat-Madras .

$388-424$

CHAPTER XIV.

$$
\text { I84r. }
$$

Fighting the Governor-General .

- 425-441

CHAPTER $X \nabla$.

$$
\text { I 84I-I } 843 \text {. }
$$

Tine College and its Spiritual Frut 


\section{INTRODUCTION.}

Alexander Duff, as the perusal of this admirable memoir will make apparent, was one of the most emi. nent of modern missionaries. His name will go down to posterity with those of William Burns and David Livingstone, as together constituting "the three migh. ties" of the noble band of Scottish worthies whose labors in the fields of heathenism have given lustre to the annals of our century. Others might be ranked among the thirty; but they were "the first three," each of whom was distinguished by making a new departure in the great enterprise to which they had all devoted themselves.

Livingstone saw that if anything was to be really done for Africa, the slave-trade-that open sore of the world-must be got rid of, and in order to secure that, as well as other things of importance, he entered upon these exploring expeditions which have made his name imperishable. Burns, upon perceiving the prejudice of the Chinese against foreigners of every sort, and finding his European dress a hindrance in the prosecution of his work, deliberately adopted the costume of the people among whom he labored, became as a Chinaman to the Chinese, and left a name at the mention of which the hearts of multitudes, both in Scotland and in China, are 
quickened as by some potent spell, for they knew him as their spiritual father. Duff, seeing that the false science of the so-called sacred books of India was in. separably connected with their religious teaching, came to the conclusion that the thorough education of the Hindoos would be subversive of the native superstitions. He, therefore, not without the risk of being misunderstood by the committee at home, deliberately adopted what may be called the educational plan. How that was carried out by him, and the influence which he exerted on education in India through Lord William Bentinck, Sir Charles Trevellyan, and the young commissioner who was afterwards to become better known as Lord Macaulay, is set forth with sufficient distinctness in these pages. He was an uncompromising advocate of that which he believed to be right, and his eloquence, alike in Calcutta and in Scotland, often carried all before it. On his first return to his native land he was virtually put, by the objections of many, upon his own defence, and the speech which he delivered on that occasion, in the General Assembly, has always been referred to as one of the graudest specimens of sacred eloquence. The ten years' conflict was then at its height, but Moderates and Erangelicals alike laid down their arms to listen, even as the hostile hosts at Talavera forgot their enmity as together they drank from the brook that flowed between their lines.

Thus the work of Duff was as important among the churches of his native land as it was in India. His zeal and oratory kindled an amazing enthusiasm for the 
missionary cause, and his simple, fervent piety always preached a silent sermon of great power. His visit to the manse of Ellon wrought such a change on the Rev. James Robertson-the leader of the Moderate party in the church-that Robertson's biographer does not hesitate to speak of it as a conversion; and wherever he went he was recognized as being in very deed "a man of God."

His labors in America are yet remembered with gratitude and admiration by multitudes among us, who will be glad to have former impressions recalled by the account which is here given of his visit to our land. And students of Scottish ecclesiastical history will find in this biography, which spans the fifty years between Chalmers's professorship of Moral Philosophy at St. Andrews, and the breaking up of the union negotiations between the disestablished Presbyterian churches, rich material for their purpose.

We need not do more than refer to the labors of Duff in later years as the Convener of the Foreign Mission Committee of the Free Church, and the first Professor of Evangelistic Theology in its college. To the last he was a man of power, tall and stalwart in form, easily distinguishable, in later years, by his flowing beard of silvery whiteness, he was always an object of interest to the visitor to the Free Assembly, and though the volcanic fire of his old eloquence had largely burnt itself out, it occasionally fiamed forth even then in such a way as to give one some idea of its former brightness. It is always difficult to convey an adequate impression 
of eloquence to those who have not heard it, and it may be that the accounts here given of that of Duff may seem to be exaggerated. But let the reader remember that the essence of oratory is too volatile and subtle to linger on the printed page. A far better test than the reported speech is found in the permanent effects which it produced, and judged by that the eloquence of Duff must have been second only to that of Chalmers; for if the Free Church of Scotland was the result of the one, the Indian Missions, both of the Established and Free Churches, were as really the fruit of the other.

But enough. It seems to me to savor of presumption that I should even thus allude to one whose "praise is in all the churches," and my only apology for writing these sentences must be that I am glad of having my name associated in any lowliest manner with that of one of the greatest missionaries of his age.

December, 1879.

W. M. T. 


\section{LIFE}

oร

\section{ALEXANDER DUFF, D.D., LL.D.}

\section{CHAPTER I.}

1806-1829.

\section{THE BOY AND THE STUDENT.}

Alexander Duff's spiritual Ancestry.-The Prince of the English Evangelicals and the Prince of Missionaries.-James Duff and Jean Rattray.-Auchnahyle and the Cottage at Balnakeilly.Ben-i-vrackie, Pitlochrie, and Killiecrankie Pass. - T'he Duff Chnrch and the Duff Tombstone.-Portrait of a Cottage Patriarch.-Dugald Buchanan and David Hume.-Gaelic poems of "The Skull," and "The Day of Jndgment."-Alexander Duff's First Dream. - The Call in his Second Vision.-Early Schoulmasters.-Lost in the Snowstorm of 1819.-A year with Moncur at Perth Grammar School.-Influence of "The Paradise Lost."St. Andrews University as it was.-Pictures of the Student by surviving Contemporaries.-Five years of Thomas Chalmers.The St. Andrews University Missionary Society. - Letter to Dr. Chalmers.-Alexander Duff, M.A.-Licensed to preach the Gospel.

ПHE spiritual ancestry of Alexander Duff it is not 1 difficult to trace to Charles Simeon. Heredity, even on its physical side, is a mystery which modern science has as yet failed to explain. Much more difficult is it to discover all that is comprehended in the influences through which the character receives its motive power and peculiar colouring. It was the remark of 
Duff himself, when, in the fulness of his fame, he solemnly congratulated a joung friend on a firstborn son, that in nothing is the sovereignty of God so clearly seen as in the birth of a child; the fact, the sex, the circumstances, the bent. To be at all, is much; to be this rather than that is, to the individual, more : but to be the subject and the channel of a divine force such as has made the men who have reformed the world, in the days from the apostles to the greatest modern missionaries, is so very much more, that we may well look in every case for the signs which lie about their infancy. In this case these signs are near the surface. It was through the prince of the Evangelicals of the Church of England that, unconsciously to both, grace flowed, at one remove, to the distant Highland boy of the Presbyterian kirk, who became the prince of Evangelical missionaries. And the grace was the same in both for it was marked by the catholicity of true Evangelicalism, which is not always found in the sectarian divisions and strifes of the Reformed Churches.

It was just after that conversation of his which proved to be the foundation of the Church Missionary Society that, in 1796, the accomplished English clergyman who filled the pulpit of Trinity Church, Cambridge, was induced to make his first tour through Scotland. At Dunikeld, Simeon tells us, his horses were at the door to take him on to the Pass of Killiecrankie, with the intention of at once turning back to that gate of the Highlands in order to hurry on to Glasgow. But "I felt myself poorly, I ordered them back and proceeded to Killiecrankie the next day. At Moulin, a village four miles from K., I called to sec a Mr. Stervart." In that visit was the seed of Alexander Duff's higher life. Having seen the pass, Simeon returned to assist Mr. Stewart, who was the parish minister, at 
the Lord's supper. Their intercourse resulted in an immediate change in the preaching of a man of high repute for amiability and learning, but, like the young Chalmers afterwards, "very defective in his view of the gospel and in his experience of its power." From that moment Stewart "changed the strain of his preaching, determining to know nothing among his people but Jesus Christ and Him crucified."

Years afterwards, as Simeon looked back on that visit to Scotland, and saw how in Moulin, at Dingwall, and then in the Canongate of Edinburgh, Dr. Stewart was made a living power to the souls of men and women, he blessed God for the indisposition which had kept him back at Dunkeld, and so had sent him to Moulin. This, and the results of his preaching for Dr. Colquhoun in Leith, led the Evangelical whom the University then despised and his own brethren condemned for preaching in non-Anglican churches, to write, " amongst the many blessings which God vouchsafed to me in those journeys, there were two in particular for which I have reason to adore His name." After this, Simeon sent out to India the men, like David Brown and Henry Martyn, who, as chaplains and missionaries, formed the salt of the infant empire. He soon saw, also, one of the noblest of evangelizing agencies established, the Church Missionary Society; and he had helped the London Missionary Society, fruitful parent of similar organizations in Great Britain, America and Germany. But the far-reaching consequences of that day's work in Moulin he had not dared to dream of.

Among Stewart's parishioners, of whom he had told Simeon there are "few real Christians whom I can number in my parish," were two young people, who were not long in experiencing the new electric thrill which showed itself in more than one revival such as a 
few of the most aged villagers recall with fond memory at the present day. James Buff and Jean Rattray were under seventeen when Simeon preached what he at the time bewailed as his barren and dull sermon. Gaelic was the prevailing language of the district; few knew English. But what the English of Simeon began, the Gaelic of Stewart continued, and James Duff was equally master of both languages. In due time he married Jean Rattray and took her to the farm of Auchnahyle. There Alexander Duff was born to them, on the 25th April, 1806. Removing thence soon after somewhat nearer Moulin, the boy's childhood and early youth was spent in and around a picturesque cottage on the estate of Balnakeilly. No trace remains of the old house of Auchnahyle, a new one having been built on its site. All the missionary's early reminiscences were identified with the cottage at Balnakeilly, still standing and but little changed, among the woods that slope up from the old north road before it enters Moulin from Dunkeld.

And here, as he himself once wrote, " amid scenery of unsurpassed beauty and grandeur, I acquired early tastes and impulses which have animated and influenced me through life." To its natural beauty of hill, wood and water, on which the artist's eye loves to rest, there is now added the memory of him whose whole genius was coloured by the surroundings, and who, when the shadow of death was darkening over him, delighted to recall the dear father-house. It is the centre of Scotland. Rising gently some two miles to the north-east, Ben-i-vrackie reaches a height of 2,800 feet. Thence the young eye can descry Arthur's Seat which guards Edinburgh, and, in the far north of Aberdeenshire, the mightier Bens of Nevis and Macdhui. The house is beautifully placed in an open glade, with a brattling mountain stream 
on either side, and a wealth of weeping birch, ash, larch, and young oak trees, which, in the slanting autumn sun, seem to surround the cottage with a setting of gold. Twice in after years, with a loving and eloquent fondness, was he led to describe the. place and the father who trained him there. When in Calcutta, in 1860, he observed in the Witness newspaper an advertisement soliciting subscriptions for a new Free Church for the parish, which the altered times made it desirable to erect in the neighbouring railway town of Pitlochrie, he thus wrote in a public appeal :-

"The parish of Moulin, fairly within the Grampians, embraces the central portion of the great and noble valley of Athole, watered by the Tummel and the Garry, with several glens and straths stretching considerably to the north. The great north road from Dunkeld to Inverness passes through the southerly section of the parish, along the banks of the forenamed rivers. About a mile to the north of this road, and wholly concealed from it by intervening knolls and ridges, lies the village of Moulin, in a hollow or basin, once partly the bed of a lake, but now drained and turned into fertile corn-fields, with the ruins of an old castle in the middle of them. Formerly the half, probably the greater half of the population lay to the north, north-west, and north-east of the village. But things are very much altered now. From the enlargement of farms entire harnlets have been removed, and the cottars in most villages in these directions greatly reduced in number; while one glen has been wholly, and more than one to a considerable extent depopulated, to make way for sheep-walks."

The Pitlochrie portion of his native parish he described as "slightly elevated on rolling ridges above the Tummel, which, after its junction with the Garry 
a little above, flows on to join the Tay a fer miles farther down; with the country all around richly wooded, while free from all marshy ground and cultivated like a garden; encompassed on all sides, and at no great distance, with swelling hills and craggy precipices, and the sharp pointed peaks of the lofty Ben-i-vrackie towering up almost immediately behind it; placed, also, within a mile or two of the celebrated Pass of Killiecrankie, which is bounded on the east by Fascally, with its enchanting scenery including the Falls of Tummel, and on the west by the battle-field on which Lord Dundee, 'the Bloody Clavers,' the relentless scourge of Scotland's true patriot worthies, the heroes of the Covenant, and the last hope of the Stewart dynasty, fell mortally wounded in the hour of victory; and which itself furnishes to the true lover of nature's works a variety of views altogether unsurpassed in their combination of the beautiful, the picturesque, the romantic, and the sublime."

The Duff Church now stands in Pitlochrie as the solitary memorial there of the man who has given a new and higher interest to that portion of the Grampian range than any of its sons. No; not the only memorial. There is another, a tombstone in the Moulin kirk-yard, " erected as a grateful tribute to the memory of his pious parents . . . by their affectionate son, Alexander Duff." When, early in 1848, he heard in Calcutta of his father's death, be sent to Dr. Tweedie a prose elegy on that cottage patriarch, which, undesignedly, enables us to trace the spiritual influence as it had flowed through Simeon, Stewart, and the good old Highlander to the sun, who had been then for nearly twenty years the foremost missionary in India.

"If ever son had reason to thank God for the prayers, the instructions, the counsels, and the con- 
sistent examples of a devoutly pious father, I am that son. Though sent from home for my education at the early age of eight, and though very little at home ever after, the sacred and awakening lessons of infancy were never wholly forgotten; and, in the absence of moulding influences of regenerating grace, the fear of offending a man who inspired me in earliest boyhood with sentiments of profoundest reverence and love towards himself, as a man of God, was for many a year the overmastering principle which restrained my erring footsteps and saved me from many of the overt follies and sins of youth. Originally aroused to a sense of sin and the necessity of salvation, when a young man, under the remarkable ministry of the lato Dr. Stewart of Moulin, and afterwards of Dingwall, and the Canongate, my father was led to flee for refuge to the hope set before him in the gospel. And the spark of light and life then enkindled in his soul, far from becoming dim amid the still surviving corruptions of the 'old man' within, and the thick fogs of a carnal earthly atmosphere without, continued ever since to sline more and more with increasing intensity and vividness. In the days of his health and strength, and subsequently as often as bealth and strength permitted, he was wont to labour much for the spiritual improvement of his neighbourhood, by the keeping or superintending of Sabbath schools, and the holding of weekly meetings, at his own house or elsewhere, for prayer and scriptural exposition. In prayer he was indeed mighty - appearing at times as if in a rapture, caught up to the third heavens and in full view of the beatific vision. In the practical exposition and home-thrusting enforcement of Scripture truth he was endowed with an uncommon gift. In appealing to the conscience, and in expatiating on the bleeding, dying love of the Saviour he displayed a power before which many have 
been melted and subdued-finding immediate relief only in sobs and tears-and being equally fluent in the Gaelic and English languages, he could readily adapt himself to the requirements of such mixed audiences as the Highlands usually furnish.

"In addressing the young he was wont to manifest a winning and affectionate tenderness, which soon riveted the attention and captivated the feelings. His very heart seemed to yearn through his eyes as he implored them to beware of the enticement of sinners, and pointed to the outstretched arms of the Redeemer. Seizing on some Bible narrative or incident or miracle or parable, or proverb or emblem, he would 'picture out' one or other of these so as to leave a clear and definite image on the youthful mind. And when he fairly entered on the full spirit of some stirring theme, such as Abraham's offering of his son Isaac, or Jesus weeping over infatuated Jerusalem; or when, piercing through the outer folds, he laid bare the latent significance of some rich and beautiful emblem, such as the 'Rose of Sharon,' the 'Lily of the Valley,' or the great 'Sun of Righteousness,' his diction would swell into somewhat of dramatic energy, and his illustrations into somewhat of the vividness and sensible reality; while his voice, respondent to the thrilling within, would rise into something like the undulations of a lofty but irregular chant, and so vibrate athwart the mental imagery of the heart, and leave an indelible impression there.

"Next to the Bible my father's chief delight was in studying the works of our old divines, of which, in time-worn editions, he had succeeded in accurnulating a goodly number. These, he was wont to say, contained more of the 'sap and marrow of the gospel' and had about them more of the 'fragrance and flavour of Paradise,' than aught more recently produced. 
Halyburton's 'Memoirs' was a prime favourite; but of all merely human productions, no one seemed to stir and animate his whole soul like the "Cloud of Witnesses.' And he took a special pains to saturate the minds of his children with its contents. His habit was orally to tell us of the manner in which the Papacy corrupted God's word and persecuted God's people. He would show us pictures of the enginery and processes of cruel torture. He then would give some short biographical notice of one or other of the suffering worthies; and last of all conclude with reading some of the more striking passages in their 'Last Words and Dying Testimonies.' To this early training do I mainly owe my 'heart-hatred' of popery, with any spiritual insight which I possess into its subtle and malignant genius, its unchanged and unchangeable anti-christian virulence.

"During his latter days, his answer to every personal inquiry was, ' I am waiting till my blessed Master call me to Himself.' His unsparing exposure and denunciation of the follies, levities and vanities of a giddy and sinful world subjected him, in an uncommon degree, to the sneers, the ridicule, the contempt and the calumny of the ungodly. But like his Divine Master, when reviled he strove not to suffer himself to revile again. His wonted utterance under such trials was, 'Poor creatures, they are to be pitied, for they know not what spirit they are of ;' or, 'Ah! wcll, it is only another reason why I should remember them more earnestly in prayer. The day of judgment will set all right.' In the sharpness and clearness with which he drew the line between the merely expedient and the absolutely right and true ; in his stern adhesion to principle at all hazards; in his ineffable loathing for tem porizing and compromise, in any shape or form where the interests of 'Zion's King and Zion's cause' 
were concerned; in his energy of spirit, promptness of decision, and unbending sturdihood of character; in the $\Delta$ braham-like cast of his faith, which manifested itself in its directness, simplicity, and strength-in all these and other respects he always appeared to me to realize fully as much of my own beau-ideal of the ancient martyr or hero of the Covenant as any other man I ever knew. Indeed, had he lived in the early ages of persecution, or in Covenanting times, my persuasion is that he would have been among the foremost in fearlessly facing the tyrant and the torture, the scaffold and the stake. Oh that a double portion of his spirit were mine, and that the mantle of his graces would fall upon me!"

This history will show how richly the prayer was answered; this letter itself does so. But the pictures of the "Cloud of Witnesses" were not all that fired the imagination of the Highland boy. Like Carey with his maps of the heathen world, the father spoke to his children from such representations of Jugganath and the gods of India as were rarely met with at that time. On another occasion the son thus traced the specially missionary influences which surrounded him as a child: "Into a general knowledge of the objects and progress of modern missions I was initiated from my earliest youth by my revered father, whose catholic spirit rejoiced in tracing the triumph of the gospel in different lands, and in connection with the different branches of the Christian Church. Pictures of Jugganath and other heathen idols he was wont to exhibit, accompanying the exhibition with copious explanations, well fitted to create a feeling of horror towards idolatry and of compassion towards the poor blinded idolaters, and intermixing the whole with statements of the love of Jesus."

Another of Alexander Duff's early and constant 
schoolmasters out of school was the Gaclic poet, Dugald Buchanan, catechist in the neighbouring Rannoch a century before, who has been well described as a sort of Highland repetition of Jolın Bunyan * in his spiritual experiences. The fire, the glow, of the missionary's genius was Celtic by nature and by training. The fuel that kept the fire from smouldering away in a passive pensiveness was the prophetic denunciation, varied only by the subtle irony, of poems like "Latha Bhreitheanais"-The Day of Judgment, and "An Claigeann"-The Sloull. The boy's great and fearful delight was to hear the Gaelic lamentations and pæans of Buchanan, which have attained a popularity second only to the misty visions of Ossian, read or rehearsed by his father and others who had committed them to memory. Buchanan is the man who, when challenged by David Hume to quote language equal in sublimity to Shakespeare's well-known lines beginning "The cloud-capt towers, the gorgeous palaces," gravely recited the Revelation which opens, "I saw a Great White Throne," when the sceptic, admitting its superiority, eagerly inquired as to its author!

The bard of Rannoch moralizes in lines some of which, as translated by Professor Blackie, we quote, from their applicability to him whom they so influenced :-

"I sat all alone,

By a cold grey stone, And behold a skull lay on the ground! I took in my hand, and pitiful scanned Its ruin all round and round.

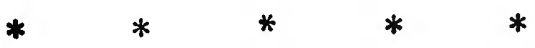

* Professor J. S. Blackie on The Language and Literature of the Scottish Highlands. 1876. 
"Or wert thou a teacher

Of truth and a preacher,

With message of mercy to tell;

With an arm swift and strong

To pull back the throng

That headlong were plunging to hell?

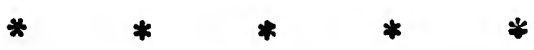

"Or wert thon a wight

That strove for the right,

With God for thy guide in thy doing ?

Though now thou lie there

All bleachèd and bare,

In the blast a desolate ruin,

"From the tomb thou shalt rise

And mount to the skies,

When the trump of the judgment shall bray;

Thy body of sin

Thou shalt slip like a skin,

And cast all corruption away.

"When in glory divine

The Redeemer shall shine,

The hosts of His people to gather,

When the trumpet hath blared,

Like an eagle repaired

Thou shalt rise to the home of thy Father."

The more weird and alarming strains of The Day of Judgment so filled the boy's fancy that, when he first left home for the Lowlands, he one night dreamed he saw the signs of the approaching doom. In vision he beheld numbers without number summoned where the Judge was seated on the Great White Throne. He saw the human race advance in succession to the tribunal, he heard sentence pronounced upon men-some condemned to everlasting punishment, others ordained to everlasting life. He 
was seized with an indescribable terror, uncertain what his own fate would be. The doubt became so terrible as to convulse his very frame. When his turn for sentence drew near, the dreamer awoke shivering very violently. The experience left an indelible impression on his mind. It threw him into earnest prayer for pardon, and was followed by what he long after described as something like the assurance of acceptance through the atoning blood of his Lord and Saviour Jesus Christ.

The next harvest vacation was marked by another experience of a similar kind, in which those who keep the ear of the soul open for every whisper of the divine, will read a prophetic call in the light of the boy's future. He had not long before narrowly escaped drowning in the more easterly of the two streams around the cottage, having been drawn into it as he was lifting out water from the swollen torrent, and swirled under the rustic bridge. The more peaceful westerly burn was the scene of his second vision. He dreamed, as he lay on its banks among the blae-berries musing alone, that there shone in the distance a brightness surpassing that of the sun. By-and-bye from the great light there seemed to approach him a magnificent chariot of gold studded with gems, drawn by fiery horses. The glory overawed him. At last the heavenly chariot reached his side, and from its open window the Almighty God looked out and addressed to him, in the mildest tones, the words, "Come up hither; I have work for thee to do." In the effort to rise he awoke with astonishment, and told the dream in all its details to his parents. Not long before his death, he repeated it in this form to his grandson, so deep and lasting had been the impression. Such a call, be it the prevision of fancy or the revelation of a gracious 
destiny, was a fitting commencement of Alexander Duff's career, and a very real preparation of him for the work he had to do.

The parish "dominie" of Moulin was an exceptionally useless teacher, even in those days and under an "indifferent" Presbytery. Amiable, ingenious, and even learned, he divided his time between the repair of watches and violins during school hours when the elder children heard the lessons of the younger, and fishing in the Tummel when his wife heard all read the Bible in the kitchen. A father of James Duff's intelligence and earnestness was sorely perplexed when, in 1814, a friend invited him to send Alexander to a school between Dunkeld and Perth, which the neighbouring farmers, engaged in reclaiming some wastes of the Duke of Athole, had established for their children. After three years of rapid progress, the boy of eleven was placed in the Kirkmichael school, twelve miles from Moulin, though not till his father had visited the teacher with whom Alexander was to board, and had satisfied himself that there was good ground for his great reputation all over the country-side. In time the sluggish Presbytery of Dunkeld awoke to the new educational light, and a deputation of their number found Alexander Duff, as the head of the school, put forward to read the Odes of Horace.

Mr. A. Macdougall was master of Kirkmichael school. In his family and under his teaching Alexander Duff laid the foundation of a well-disciplined culture, for which, so long as his teacher lived, he did not cease to express to him the warmest affection. Among his fellows were Dr. Duncan Forbes, who afterwards became Professor of Oriental Languages in King's College, London; Dr. Tweedie, associated with the future missionary as convener of the Foreign Missions Committee of the Free Church of Scotland; 
the Rev. Donald Fergusson, still Free Church minister of Leven; and the Rev. Mr. Campbell, the present parish minister of Moulin. Such was the teacher's ability, and such his well-deserved popularity, that the thinly peopled parish at one time sent eleven students to St. Andrews. "I have not forgotten the days I passed under your roof," wrote Duff when he had become famous, to his old master, "nor the manifold advantages derived from your tuition, and, I trust, never will. And when the time comes that in the good providence of God I shall visit Kirkmichael, I know that to me at least it will be matter of heartfelt gratification." "What would I have been this day," he wrote again, "had not an overruling Providence directed me to Kirkmichael school?" Of every book and pamphlet which he wrote he sent a copy to his first benefactor.

Before he left Kirkmichael to pass through the then famous grammar school of Perth to St. Andrews University, he was to carry with him from his home another experience never to be forgotten.

The winter at the end of 1819 was severe, and the snow lay deep in the Grampians. The Saturday had come round for young Duff's weekly visit to his parents. Taking the shorter track for ten miles across the low hill by Glen Briarchan and Strathire, from Kirkmichael to Moulin, he and a companion waded for hours through the snowy heather. The sun set as they got out of the glen, no stars came out, all landmarks were obliterated, and they knew only that they had to pass between deep morasses and a considerable tarn. To return was as impossible as it was dangerous to advance, for already they felt the ice of the moss-covered pools and then of the lake cracking under their feet in the thick darkness. Still going forward, they came to what they took to be 
a precipice hidden by the snow-drift down which they slid. Then they heard the purling of the burn which, they well knew, would bring them down the valley of Athole if they had only light to follow it. The night went on, and the words with which they tried to cheer themselves and each other grew fainter, when exhaustion compelled them to sit down. Then they cried to God for deliverance. With their heads resting on a snow-wreath they were vainly trying to keep their eyes open, when a bright light flashed upon them and then disappeared. Roused as if by an electric shock, they ran forward and stumbled against a garden wall. The light, which proved to be the flare of a torch used by salmon poachers in the Tummel, was too distant to guide them to safety, but it had been the means of leading them to a cottage three miles from their home. The occupants, roused from bed in the early morning, warmed and fed the wanderers. To Alexander Duff's parents the deliverance looked almost miraculous. Often in after years, when he was in peril or difficulty, did the memory of that sudden flash call forth new thankfulness and cheerful hope. Trust in the overruling providence of a gracious God so filled his heart that the deliverance never failed to stimulate him to a fresh effort in a righteous cause when all seemed lost.

The boy spent his fourteenth year at Perth Grammar School, of which Mr. Moncur, the ablest of the students of John Hunter of St. Andrews, and a born teacher, had just been made Rector. The first act of the new master was, in presence of the whole school, to summon the janitor to sink in the Tay the many specimens of leathern "tawse" of various degrees of torturing power, which had made his predecessor feared by generations of boys. With consummate acting, he asked why the generous youtbs entrusted 
to him should be treated as savages. He at least had confidence in them to this extent, that each would do his duty; and, being the perfect teacher he was, his confidence was justified. The scene was never forgotten, and it went far to develop in Duff the power which fascinated and awed his Bengalee students for many a year, and made his school and college the first in all Asia. Under Moncur his Latin and Greek scholarship had their foundation broadened as well as deepened. In the favourite optional exercise, now too much neglected, of committing to memory the master-pieces of both, he generally came off first, and thus was trained a faculty to which much of his oratorical success afterwards was due. He left Perth at fifteen, the dux of the school. Yet we question if he carried away from it anything better than Johnson's "Rambler," which the Rector lent to him for the vacation before the University term, and especially Milton's "Paradise Lost." Often in after years did he refer to the latter as having, unconsciously at the time, exercised a great influence over his mental habitudes. He carried the book constantly in his pocket, and read portions of it every day. Thus the "Paradise Lost" moulded his feelings and shaped his thoughts into forms peculiarly his own. The Gaelic Buchanan and the English Milton, the Celtic fire and the Puritan imagination, feeding on Scripture story and classic culture, coloured by such dreams and experiences, and directed by such a father and a teacher-these were used to send forth to the world from the bosom of the Grampians a tall eagle-eyed and impulsive boy of fifteen. Presented with twenty pounds by his father, from that day he was at his own charges.

It was a fortunate circumstance that he went to St. Andrews. Of the four Scottish universities at that time the most venerable was still the most 
attractive, from the renown of some of its professors. Iittle, of course, could be said for the schools of divinity anywhere till Thomas Chalmers went to Edinburgh, although Principal Haldane was not without routine ability and goodness, as head of St. Mary's, the theological college which Cardinal Beaton had founded. But the other two, known as the United Colleges of St. Salvator and St. Leonard, enjoyed the Bervices of the ripest Latinist at that time in the United Kingdom, Dr. John Hunter, and of Dr. Jackson whose lectures on natural philosophy were reckoned the most scientific of the day. The reputation and the influence of even these, however, were confined to their generation compared with that intellectual and spiritual ferment caused by the new professor of moral philosophy, which is still working in the lives of men and the institutions of his country. When Dr. Chalmers almost suddenly disappeared from the pulpit and platform, the wynds and the hovels of Glasgow, and began the winter session of 1823-24 at St. Andrews with one lecture, Alexander Duff, having carried off the highest honours in Greek, Latin, logic, and natural philosophy, was one of the crowd who sat at the great professor's feet. His Latin had procured for him the most valuable of those rewards which Scotland, with its peculiar mixture of Latin and French theological and law terms, calls "bursaries," without sufficiently distinguishing between the prizes of genuine scholarship gained by hard competition, like Duff's, and the doles restricted to poor students, often because they bear the same name or have been born in the same district as the thoughtless or vain donor. Especially had he carried off the essay prize offered for the best translation into Latin of Plato's "Apology of Socrates," and the Senatus spontaneously dubbed him Master of Arts. 
The impetuous spirit of Duff received impressions of the theological deadness of St. Andrews, and of the new life brought to it by Chalmers, which found this expression, when recalled in the distant scenes of India: "Poor St. Andrews lay far away, isolated and apart, in a region so cold that the thaw and the breeze, so relaxing and vivifying elsewhere, scarcely touched its hardened soil. The great stream of national progress flowed past, leaving it undisturbed in its sluggishness. The breezes of healthful change blew over it, as over the unruffled surface of a land-locked bay. From all external influences, even of an ordinary kind, it seemed entirely shut out. No steamer ever entered its deserted harbour, with its influx of strangers carrying along with them new tastes, new habits and new thoughts. No mail-coach or even common stagecoach ever disturbed the silence of its grass-grown streets. Its magistracy was virtually self-elected, enjoying in perpetuity a quiet monopoly of power. The Rector, the very guardian and controller of its University, must be himself one of the existing principals or professors of divinity; and not, as in the case of other Scottish universities, a man beyond the collegiate pale-a man of name, of independency and power, whose occasional visitation might tend to shake the dry bones of dull, deadening, monotonous routine. Dissent, so rife and flourishing elsewhere, could barely show itself in the nerveless impotence of creeping infancy. And even the rising spirit of the missionary enterprise could only faintly struggle, and that too in the bosoms of but a few, not for life but for a sickly weary existence, just as the palm or other rich product of tropical climes might for a time be seen painfully struggling for existence on a bleak Grampian heath.

"Such was the condition of St. Andrews,-a con- 
dition in which the gaunt spirit of the eighteenth century, mantled all over with the deadly night-shade, was felt still shooting his baleful breath far into the nineteenth, - a condition in which the policy and the power of 'moderate' ascendancy were comparatively unmodified and unchanged, when, in the spring of 1823 , it was suddenly announced that Dr. Chalmers was unanimously elected by the Senatus Academicus to the vacant chair of Moral Philosophy. And when it is remembered that at that time not one member of the Senatus belonged to the evangelical party in the Church, that all were moderate and some of them intensely so, and that Principal Nicoll was even the acknowledged leader of the moderate party in the General Assembly; it may well be imagined how the unexpected announcement was received with mingled feelings of surprise and delight-surprise at the choice of such a man by such an elective body, delight that the choice should have fallen on one so transcendently worthy. Indeed, 'delight' is far too feeble and inadequate a term to express the full gust of pleasurable emotion which instantaneously followed the announcement, and speedily diffused itself through the whole community. It was rather a burst of high-wrought enthusiasm. Of some it might truly be said that they believed not for very joy.

"Doubtless the sources of this joy were of an exceedingly varied and mingled description. Visions of temporal aggrandizement already floated before the minds of the townspeople, then sadly steeped in secularity and religious indifference. Without commerce, without manufacture or any leading branch of industrial occupation, their very existence might be said to depend on the University. And in the presence of such a 'celebrity' as Dr. Chalmers, they were sharp enough to behold such a nucleus of attraction for 
students and strangers generally, that his residence amongst them might fairly be regarded as cquivalent to an increase of thousands of pounds to their scanty annual income. Again, many of the inhabitants, alike of town and country, had numberless traditionary local anecdotes and recollections of him as a boy, a student, a lecturer on mathematics and chemistry, and lastly, as the eccentric minister of the neighbouring parish of Kilmany. And to receive him back again amongst them, in the full blaze of an unparalleled popularity, they felt to be like the shedding of some undefinable radiance on themselves. The fer, the very few, scattered and almost hidden ones of piety and prayer, hailed the event with feelings somewhat akin to those of him who beheld the cloud laden with its watery treasure rise and swell from the west, after a long and dreary season of parching drought. As for the students, however careless or unconcerned as to purely spiritual interests, they were, without any known exception and with all the honest fervour of youth, enraptured at the thought of having for a professor a man of genius, and the greatest pulpit orator of his age. The dull dead sea of former apathy and inertness was suddenly stirred up from the depths by the rush and impulse of now and unwonted excitement. For many days they could think of nothing else, and speak of nothing. The third volume of 'Peter's Letters to his Kinsfolk,' with its portrait and graphic delineation of Dr. Chalmers, obtained from the college library, was well-nigh torn and shattered from the avidity for its perusal. Already did every one picture to himself the form of the man with his pale countenance and drooping eyelids; his mathematical breadth of forehead with its 'arch of imagination,' surmounted by a grand apex of high and solemn veneration and love. Already, with anticipated breath- 
lessness, did each one seem, in fancy, as if he felt his nerves creeping and vibrating, and his blood freezing and boiling, when the eloquence of the mighty enchanter, bursting through all conventional trammels, shone forth in all the splendour of its overpowering glories.

"At length the time of his installation came round. In November, 1823, he delivered his inaugural lecture in the lower hall of the public library, still called the 'Parliament Hall,' as there, in 1645, the Covenanting Parliament assembled which tried and condemned Sir Robert Spottiswood and other royalists for their share in the battle of Philiphaugh." Dr. Hanna has told the rest in the memoirs of his great father-inlaw.

Such were the professors. And what the students? There had followed Duff to St. Andrews an old schoolfellow from Perth, John Urquhart, with whom he shared the same lodgings, and, morning and evening, engaged in the same worship. Urquhart was a Congregationalist, as were also John Adam and W. Lindsay Alexander, who is still spared to the Church, and has written this bright sketch of Duff in their student days: "When I first became acquainted with him he was in all the vigour and freshness of early youth, stalwart in frame, buoyant of spirit, full of energy and enthusiasm, impulsive but not rash, a diligent and earnest student, and already crowned with academic distinctions earned by success in different departments of learned and scientific study. His reputation stood high as a classical scholar, and he had gained several prizes for essays in literature and philosophy. Subsequently to the time of which I am speaking, he gained equal distinction as a Hebrew scholar, and his essays in theology commanded the strongest approbation from his professors. Already also as a speaker, 
he had in debating societies, and subsequently by his discourses in the Theological Hall, displayed that intellectual power and that rare gift of eloquence which enabled him in after-years so mightily to sway the emotions, guide the opinions, and influence the decisions of others, in deliberative councils no less than in popular assemblies."

One of his juniors, the son of Professor Ferrie, and now the Rev. William Ferrie, in the State of New York, gives us this other and very human glimpse of the impetuous student:- " $\mathrm{He}$ was passing the windows of my father's house in St. Andrews with others going to some great students' meeting, and I remember Nairne, who was then my tutor, called out as they passed, "There is Duff.' I looked, and he had on a cloak, and was going with a good thick stick in his hand, as though he expected that there might be a row." The Rev. J. W. Taylor, of Flisk, whose first year at college was Duff's last, writes: "Though outrageously thoughtless I was much impressed by Duff. There was a weight and a downright earnestness about him which everybody felt. $\mathrm{He}$ was the boast of the college, and was greatly regarded by the townsfolk of St. Andrews. His appearance as he passed with hurried step is indelibly photographed on my mind, and is thus put in my 'Historical Antiquities' of the city. 'That tall figure, crossing the street and looking thoughtfully to the ground, stooped somewhat in the shoulders and his band awkwardly grasping the lappet of his coat, is Alexander Duff, the pride of the college, whose mind has received the impress of Chalmers's big thoughts and the form of his phraseology. Under Chalmers, he was, in St. Andrews, the institutor of Sabbath schools and the originator of the Students' Missionary Society." "Another surviving fellow-student, Dr. A. M'Laren, the minister of Kem- 
back, near Cupar, describes him thus:-_" As a friend he was always singularly obliging, warm-hearted and constant; as a companion he was uniformly agreeable and cheerful, and not unfrequently impressive in his appeals to the better susceptibilities of our nature; though generally in high spirits and mirthful, he never allowed his mirth to degenerate into boisterous vulgarity." What the lad was at St. Andrews, the man proved to be all through his life. He was high-minded, generous and chivalrous with the bearing of the old school, and that not less after his hours of controversy than in his happiest times.

The first session was not over when the great Christian economist, the expounder of Malthus and Ricardo, who had transformed the worst wynds of Glasgow, began the humblest mission work in the more ancient city, and threw himself into the then despised cause of foreign missions. Duff's young spiritual life, which had been slumbering into formalism, he tells us, was quickened with that burning enthusiasm which glowed the brighter to his dying day. His friends, Urquhart and Adam, took steps to offer themselves to the London Missionary Society for China and Calcutta; and Robert Nesbit went to his friend John Wilson, of Lauder, begging him to break the news to his mother that he was to be sent by the Scottish Missionary Society to Bombay. It is not surprising that these, and such companions as the late Henry Craik, of Bristol, Mr. Müller's colleague; William Tait, son of the godly Edinburgh minister who was deposed in the Row heresy case; and Mr. Scott Moncrieff, late of Penicuik, met with Duff in the session of 1824-5, and founded the Students' Missionary Society. Duff was its librarian, Nesbit its secretary, and R. Trail its president, as having originated an earlier society of divinity students only. Their object was to study 
foreign missions, so as to satisfy themselves of the necessities of the world outside of Christendom. Not a room for their meetings would the authorities of either college, or the magistrates who had charge of the city school, allow them, until, some time after, the principal and professors were enlightened so far as to subscribe an occasional guinea. And that in spite of all the influence of Chalmers, who fed the spirit of the students and interested the townsfolk in the cause by lecturing on some portion of the field of heatbenism once a month in the town-hall. This society, noteworthy in the history of Scottish Missions as the fruitful parent of the most apostolic missionaries of the country, met first in an adventure school in a dingy lane of St. Andrews.

The Memoir of Urquhart, who passed away all too early from the work for which he was preparing, reveals at once the depth of Duff's friendship, in the letters and in the preface to the third edition of 1869, and the very practical forms of mission study and prayer followed by the members. When Urquhart, in his concluding address, solemnly announced for the first time his personal dedication to missionary work, and charged every one of his fellows to take this matter into most serious consideration, his friend Duff received a deep and solemn impression. But books, essays, and even the lectures of Chalmers, were not all. In those days the giants of the early societies occasionally came home with news of victory in the high places of the field, with plans of further campaigns, with appeals for recruits. When Urquhart startled his companions by that announcement into following his example, he had just returned from a visit to the great missionary, Dr. Morrison, then in London, from whom he had been taking lessons in Chinese.

Dr. Chalmers kept open house for all such in St. 
Andrews, to which his sympathy with them as well as his fame attracted them. Thus the students saw Dr. Marshman, who was full of the enterprise of 1818, when he and Carey had opened, in Serampore, the first English and Sanscrit college for native missionaries and educated Hindoos. Dr. Morrison in due time came north, to plead for Hong-Kong and Canton, to which his labours were then confined; to tell of his triumphs in Bible translating and dictionary making, and to give some account of the ten thousand Chinese books which he had brought home. And from Calcutta there might be seen, at the lively breakfast table of the renowned professor of moral philosophy, the spare form of that Sanscrit and Bengalee pundit, Dr. Yates, alternating between attacks on Church establishments and expositions of Brahmanical subtleties, or listening to the professor's emphatically expressed opinion that religious societies should be managed by laymen, while ministers confine themselves to the more spiritual duties of their office.* John Urquhart was right when he wrote that the colleges of St. Andrews, under all these influences, had become like those of Oxford in the days of Hervey and Wesley. Reckoning up the fruits of the influence of Chalmers for five years on the three hundred students who passed through his classes, his accomplished biographer exclaims :- " More than one missionary for each college session-two out of every hundred studentswhat other University record can present a parallel!" The six were Nesbit, Adam, Duff and Urquhart, and Mackay and Ewart who followed them. Dr. Hanna remarks of Duff, that the life and labours of this prince of missionaries proved how truly and how intensely he

- Dr. Hanna's Memoirs of Thomas Chalmers, D.D., LL.D., vol. iii., p. 154, note. 
was impelled to tread in the footsteps and to imitate the noble pattern of his great teacher.

It was on the 19 th October, 1828, that Dr. Chalmers made this entry in his journal :-" Enjoyed my last Sunday at the beautiful garden of St. Leonard's: a sad sinking of heart." Duff returned to his last session at St. Andrews to find the light of the University leaving for the wider and more purely professional sphere of Professor of Divinity in Edinburgh. But the disappointed student found some recompense in being asked by Chalmers to write freely to him. The first fruit of a correspondence and a personal friendship which ceased, twenty years after, only with the death of the greatest Scotsman since Knox, was the following. Dr. Chalmers seems to have carefully preserved the original, having that sympathy with students which more thar doubles the preacher's and the professor's power :-

"ST. ANdews, 20th Jan., 1829.

"Rev. and Dear Sir,-When leaving St. Andrews, you were so good as to request me to write to you during the session, and I promised to do so. I assure you that neither the request nor the promise was for one moment forgotten. I reckoned the request an honour, and you know it is not human nature to neglect what is viewed in this light. . .

"The sum total of students attending the Old College is 191 ; St. Mary's, nearly 40. The session has as yet passed by very quietly. There are no gentleman outlaws or privileged desperadoes to gain an infamous notoriety by disturbing the general peace, and setting laws and discipline at open defiance. Billiards and nocturnal riots and other irregularities are therefore unheard of; and if there be an indulgence in any excesses, it is still shrouded under the veil of secresy. 
The vigorous measures taken by the professors on a former session operate as a very salutary if not an effectual check; and the rigid upholding of these measures will no doubt render the check permanent.

"Dr. Cook's arrival in St. Andrews caused little inquiry, and created little or no excitement. His introductory lecture was delivered in the Latin classroom to an audience almost solely composed of students, and not very numerous. Its brilliance may be estimated from the fact that most of the students appeared very restless and fidgety; Mr. Lothian sat yawning in one of the back seats. Dr. Cook has proclaimed himself the champion of the ancient system. He seemed to exult in having the high honour of restoring the poor houseless fugitive to its former domains, and investing it with its former dignity. His was a most perfect science: it was independent of revelation; it could exalt man to a state of dignity allied to the Fountain of being, and could achieve wonders in refining the moral constitution of the lord of nature. Moral philosophy could not be understood without a previous view of the mental faculties. This was proved and illustrated by a lengthened analogy, of which this is the substance: It is as impossible to investigate the principles of morals without a previous knowledge of the faculties of the mind-which is the instrument employed-as it is for the astronomer to have a knowledge of bis science without a previous acquaintance with the facts of astronomy. The depth of this reasoning no one could fathom, and it was unanimously enrolled among the list of paralogisms. He then gave a sketch of his course, of which I have endeavoured to send you a faithful outline. From it you will at once perceive how rigidly he intends to follow the traces of the olden time, and how St. Andrews is likely to retain its character of the 'Old Maiden' strictly inviolate. 
He concluded by a long panegyric on his father, who was one of the most distinguished of moral philosophers; and another upon Dr. Crawford, adding, 'Neither can I be supposed to be altogether unaffected by the brilliant talents and the splendid eloquence of my immediate predecessor.' Almost in the next breatb he proceeded, 'Entering the chair which I now occupy, after three such distinguished men, it may be thought that I labour under many disadvantages,' etc., and concluded by stating that he had thought long and much upon the subject, and therefore felt himself by no means unprepared to deliver a course of lectures upon moral philosophy. Upon this a certain gentleman facetiously remarked: "No wonder, for he has been preaching upon morals all his lifetime.' My own feelings, and the feelings of all those whose memories fondly dwelt upon better days and enabled them to draw a sorrowful contrast, would heartily incline me to inscribe above the docr of entrance, in legible characters, 'Ichabod, the glory is gone.' The number of students attending this class has actually dwindled to 28-not half the number for the last five years. This some of the professors account for by saying that last session some of the second-year students attended moral philosophy instead of logic, and this season they attend logic instead of moral philosophy. But the truth is, there are only four or five students of whom this can be said, leaving still the deficiency unaccounted for on any such principle. He was prepared to lecture on political economy, and every exertion was made to muster a class; but the thing would not succeed. Two students were at last induced to enrol; but such an attendance was too meagre to escape the imputation of being a farce, and accordingly the scheme was abandoned as hopeless.

"The other classes are conducted in the usual way, 
except that Mr. Duncan and Dr. Jackson have established a regular system of weekly competitions, which promise to do much good in stimulating and rewarding the really deserving.

"About ten days ago old Dr. Hunter was found in his study asleep and almost stiff with cold, his fire having gone out. For some days he was confined to bed, very unwell, but is now rapidly recovering.

"The building of a new college is still the subject of conversation. Reports have flourished without number, and repeatedly died; but the happy consummation of their dying into a reality seems yet to be somewhat distant. True, the professors talk confidently of $£ 23,000$ being granted through the intercession of Lord Melville, of the money being already in the Exchequer in Edinburgh, of the king's architect being expected every day; the foundation stone is to be laid in March, and your class-rooms are to be finished during the ensuing summer, etc., etc. These things may be true, but past disappointments suggest the propriety of not being very sanguine till actual operations are commenced.

" The Students' Missionary Society is succeeding as well as ever, its numbers in no degree diminished. Even those who were at first disposed to view it with a jealous eye and shrink from any contact with it, as being an institution quite unacademical, begin to regard. it more auspiciously and countenance it with their support. Our meetings are well attended, our books much read; so that I trust the spirit which was sud. denly kindled five years ago may long survive in this quarter at least, and demonstrate that it was not an ephemeral effervescence, founded on no principle and supported by no truth. I would rejoice to be enabled to assert the same of the Town Missionary Society. All were prepared for a great change, so that 
its decrease was not unexpected. Its monthly meetings are truly the wreck of what they were. The animating spirit is gone, and gone with it have most of the attendants. I fear they will find the greatest difficulty in keeping up these interesting meetings, and that the Society will relapse into its original state of inefficiency. Mr. Bain reads the greatest part of the evening, and $\mathrm{Mr}$. Lothian takes also a share. But there is the absence of those connecting remarks, and those appeals and addresses which, to most of the auditors, constituted the charm of the evening's business in past years. Mr. Bain is well-meaning and very anxious for its prosperity, but he wants life, energy and activity. If the new burgher-minister now to be elected, Mr. Aiken, be a popular man, he may lend effective aid and in some measure cause a revival.

"Sabbath schools have now overtaken almost the whole population. I have personally visited all the lower classes in the town, and did not find twenty children who were not attending some school or other. A very great, if not the greatest proportion appears to be taught by Dissenters-a circumstance which of course grieves Dr. Haldane very much. $\mathrm{He}$ is so much annoyed by it, that he spends no inconsiderable portion of his time in visiting the parents for the express purpose of requesting them to beware of the arts and beguiling insinuations of the Dissenters, and to remove their children from their schools ere they be tinctured with their pestiferous principles. At all events every Christian must rejoice that 'by all means' the doctrine of the Cross is now regularly and systematically taught to nearly all the children of St. Andrews.

"Dr. Haldane has contrived to muster a class of mechanics, or rather apprentice-lads, to whom I ex- 
plain an appointed passage of Scripture every Sunday morning between ten and eleven o'clock. I have the conducting of a girls' school between four and six; and later in the evening I spend an hour and a half or two hours with Messrs. Smyth, Fortune, Watson and another fellow-boarder, Robb, from Stirling. I prescribe a chapter to be read and studied for the following Sabbath, examine upon it, make remarks and explanations. Messrs. Watson and Fortune, in whose welfare you expressed yourself as interested, are conducting themselves with great propriety, and I feel very much delighted with the intelligent answers which they give to most of the questions put to them on the Sabbath evening. Mr. Craik expresses himself satisfied with the manner in which they prepare their regular class-lessons.

"I have been proposed for trials before the Presbytery of St. Andrews, and my first examination takes place on the 11th of February. I almost begin to fear when I think of the awful responsibility of the Christian ministry, and this fear sometimes makes me shrink from the office, as if it were to be tarnished by my presence. Again I reflect, that if my motives are well founded the Lord will sustain me; and if not, it were far better that I desisted in time."

In the spring of 1829, and in this spirit, Alexander Duff, M.A., was licensed by the Presbytery of St. Andrews " to preach the gospel of Christ and to exercise his gifts as a probationer of the holy ministry." The man was ready; the work had been long waiting for him. 


\section{CHAPTER II.}

1829.

\section{THE FIRST MISSIONARY OF THE OHURCH OF SCOTLAND.}

Early Missionary Confession of the Kirk.-The Apathy of Two Cen. turies.-Preparations by the Scottish Layman, Charles Grant. The Foundation of the Missionary Societies after the French Revolution.-The First Presbyterian Chaplain and English Bishop of Calcutta.-Dr. Inylis, Founder of the Mission.-Lord Binning's Help.-General Assembly's Letter to the People of Scotland.-Alexander Duff's Answer.-Announcement to his Father and Mother.-Accepted by the Foreign Mission Committee on his own Conditions.-His First Missionary Sermons.Bagster's Bible Presented to Him.-Patbetic Counsels and Farewells.-David Ewart.-Patrick Lawsou's Advice.-Marriage and Ordination.-Mr. and Mrs. Duff leave Leith for London.-Dr. Inglis to Dr. Bryce.-Letter to Dr. Chalmers.

TuE work had been waiting for two hundred and' seventy years. Alone of all the Reformed Churches the Kirk of Scotland had placed in the very front of its Confession the fact that it was a missionary church. The foresight of John Knox, the statesmanship of the Scotsmen who gave civil as well as religious freedom to the kingdom, have been extolled by secular historians so opposite as Mr. Froude and Mr. Hill Burton. But that foresight saw farther than even they acknowledge, when the Scottish Parliament of 1560 passed an Act embodying the first Confession, which has this for its motto, "And this glaid tydingis of the kyngdome sall be precheit through the haill warld for a witnes unto all natiouns, and then sall the end cum." That confession was the four days' work of John Winram, John 
Spotswood, John Willock, John Douglas, John Row and John Knox.

First self-preservation, then the attempt to throw their own ecclesiastical organization uniformly over England also by political means, and finally the reaction and the indifference which mere policy brings about, succceded in reducing the Kirk of the eighteenth century to lifelessness. What had, for all Christendom, been a series of crusades against the Turks; and for the Spanish and Portuguese discoverers in the Indies, West and East, a series of raids by the Latin Church on the native inhabitants, became in the Reformed Churches at home a defence of the orthodox faith against popery. But the General Assembly of 1647 liad expressed a wish for "a more firm consociation for propagating it to those who are without, especially the Jews. For the unanimity of all the .Churches, as in evil 'tis of all things most hurtful, so, on the contrary side, in good it is most pleasant, most profitable, and most effectual." Again do we catch a glimpse of the missionary spirit when, in sending forth ministers with the unfortunate Darien expedition, the Assembly of 1699 enjoined them particularly to labour among the natives; while its successor added, "The Lord, we hope, will yet honour you and this Church from which you are sent to carry His name among the heathen." In 1743 the Kirk indirectly supported Brainerd, and in 1774 tried to raise up native teachers in Africa. Yet so far did it decline from the ideal of Knox, that when the French Revolution and the progress of commercial discovery had roused England, America and Germany, as little Denmark had long before been stimulated, the General Assembly selected as its Moderator the minister who in 1796 carried this opinion by a majority - " To spread abroad the knowledge of the gospel among barbarous 
and heathen nations seems to be highly preposterous, in so far as it anticipates, nay, it even reverses the order of nature."

What the Kirk of Scotland refused to do till 1829, one of the greatest of its sons was for half a century carefully preparing. Charles Grant, an Invernessshire boy, was a civil servant of the East Iudia Company during the famine which swept off a third of the population of a large portion of Bengal in 1770 . From that time, as an evangelical Christian first and a Presbyterian, Baptist and Episcopalian afterwards, as his position led him, Charles Grant in India, in the Court of Directors, in the House of Commons, in society and in the press, never ceased till he induced Parliament to send out chaplains and schoolmasters, and the Churches to supply missionaries. Before Carey had landed at Calcutta and become his friend, Charles Grant had implored Simeon to send out eight missionaries, offering to receive all and himself to bear permanently the cost of two. That was before Simeon's pregnant visit to Moulin. To Charles Grant and the friends whom he stirred up, like Wilberforce and the elder Macaulay, wo owe first the Charter Act of 1793 which conceived, that of 1813 which brought to the birth, and that of $18: 33$ which completed, what we may fairly describe as the christianization of the East India Company, opening its settlements in India and China to toleration in the widest sense alike of truth and of trade.

The nearly successful attempt of Wilberforce to get "the pious clauses" of Charles Grant into the charter of 1793, though foiled by the time-serving Dundas, then dictator of Scotland, led Christian men throughout England and Scotland to do what the Churches in their corporate character were still unwilling to organize. The Baptists had shown the way under Carey, in 
1792. Presbyterians, Independents and some Anglican Evangelicals united to found the London Missionary Society in 1795 . The year after saw the more local Scottish and Glasgow Missionary Societies. And to the partly colonial, partly foreign agency of the Propagation Society, the Evangelicals of the Church of England added the Church Missionary Society, which, in 1804, sent forth to West Africa its first representatives, who were German. By its establishment of one bishop, three archdeacons, several Episcopalian and three Presbyterian chaplains in India, the charter of 1813 compelled the directors of the East India Company " to show our desire to encourage, by every prudent means in our power, the extension of the principle of the Christian religion in India." That language is sufficiently cautious, and the concession marks no advance on the orders of William III., in the charter of 1698. But it was accompanied by the very practical resolution of Parliament, without which much of Duff's career would have been very different, that "a sum of not less than one lakh of rupees ( $£ 10,000$, at par) in each year shall be set apart and applied to the revival and improvement of literature, and the encouragement of the learned natives of India, and for the introduction and promotion of a knowledge of the sciences among the inhabitants of the British territories of India." The chaplain was thus legalized, the schoolmaster was thus made possible. But it was not till 1833 that the missionary, the merchant, the capitalist, the Christian settler in any form was recognised or tolerated save as an "interloper"- that was the official term-admitted under passports, watched by the police, sometimes deported and ruined, always socially despised.

The first Scottish chaplain duly balloted for by the Court of Directors, and sent out to Calcutta, was the 
Rev. James Bryce, of Strachan, in the Presbytery of Kincardine-O'Neil. He sailed in the same East Indiaman with the first bishop selected by the President of the Board of Control, Dr. Middleton, who liked neither his Presbyterian brother nor the missionaries sent out by the Church Missionary Society under protection of the same charter. So little of a missionary spirit had the first representative of the Church of Scotland in India, that " he has no besitation in confessing that he went to the scene of his labours strongly impressed with a belief, should he step beyond the pale of his own countrymen he would find every attempt to shake the Hindoo in the faith of his fathers to be futile and unavailing." So he and Bishop Middleton fell to squabbling about sects and churches, about the height of a steeple and the name of a church building, till the Governor-Generals, Cabinet Ministers and the directors were dragged into the fray, and that in a city of which the wise Claudius Buchanan had written ten years before, that a name or a sect was never mentioned from the pulpit now filled by the Bishop, "and thus the Word preached becomes profitable to all."

Of a very different type was the Rev. Jolın Inglis, D.D. The minister of Old Greyfriars, Edinburgh, was the one man of the Moderate party in the Church worthy, as an ecclesiastic at least, to rank with his great evangelical contemporaries, Chalmers, Andrew Thomson and Sir Harry Moncreiff. His worthiness lay in the fact that, as Lord Cockburn puts it, he was the only leader of that party whose opinions advanced with the progress of the times. Ecclesiastically, in matters of Kirk diplomacy, he was a moderate, so that the same authority has described his powerful qualities as thrown away on the ignoble task of attempting to repress the popular spirit of the Kirk, although these would have raised him high in any department of 
public life. Spiritually, as a preacher, he was an evangelical, although before his death, in 1834, he had preached his church nearly empty. As an ecclesiastical lawyer, his clear thinking, lucid exposition and innate eloquence, were such as to make his hearers forget his tall, ungainly figure and raucous voice. His fruitless intolerance in the Leslie case was due to his party in 1805, and he grew out of that in the subsequent thirty years of his career, to nobler work and a finer spirit. That and smaller follies were amply atoned for by his foundation of the India Mission and his selection of the first three missionaries.

So early, comparatively for Scotland, as 1818, Dr. Inglis preached a sermon in which we find the seed of the foreign mission system of the Church of Scotland, and of the call of Alexander Duff. The one glimmering missionary taper of the Kirk since the beginning of the eighteenth century had been the "Society in Scotland, Incorporated by Royal Charter, for Propagating Christian Knowledge." Although benefiting chiefly the Gaelic-speaking Highlanders, it did spend a few small sums on au occasional missionary at Astrakhan in the East, and among the Indians of the West, while it gave grants to the Serampore and other labourers. To preach the annual missionary sermon of the society was an honour reserved for the ablest ministers, who generally talked platitudes on education or kept themselves to formal theology. But when on Friday, the 5th June, 1818, Dr. Inglis announced his text, the spirit of unconscious prediction moved him. "Is it a light thing," were the words which he read from Isaiah, "that Thou shouldest be My servant to raise up the tribes of Jacob and to restore the preserved of Israel? I will also give Thee for a light to the Gentiles, that Thou mayest be My salvation unto the end of the earth." With triumphant faith in the 
ultimate universal preva!'nce of Christianity, he saw in the prophet's message " the most exalted idea both of Divine love and human felicity." In terms only less enthusiastic than those which ever afterwards marked the first missionary whom his Church was to send forth, and far removed from the "moderatism" of the ecclesiastical party who claimed him, Dr. Inglis showed how the nature and the divine agencies of Christianity secured its future universal dominion, in spite of its very limited success at that time. Among these agencies he placed education foremost, not because he made the mistake attributed to him of requiring civilization to precede Christianity, but because out of converted savage races he might thus raise indigenous preachers, and by means of natives endowed with intellectual vigour, and with a capacity of estimating what is just and true, he might secure more abiding and ultimately rapid progress. Pointing to the conquest of the Roman Empire by the Church, he asked why our connection with our commercial dependencies should be less favourable; upon what principle we who raised factories for trade concluded that " establishments for the instruction and civilization of our benighted brethren might not be rendered signally effectual." The three cliaplains sent to India he accepted as only an instalment of the Church's and the nation's duty. The translation of the Scriptures without comment he urged as of equal importance with schools. And this was written just before the Serampore missionaries had opened the first Christian college, while the sceptical English and educated Hindoos of Calcutta were striving to establish their Anglo-Indian college on non-moral principles, from which even the theist, Rammolun Roy, dissented as fatal to the true well-being of a people.

It was Rammohun Roy, too, who was the instrument 
of the conversion of the first chaplain, Dr. Bryce, from the opinion of the Abbé Dubois that no Hindoo could be made a true Christian, to the conviction that the past want of success was largely owing to the inaptitude of the means employed. Some nine years after the confession which we have already quoted, we find Dr. Bryce writing: "Encouraged by the approbation of Rammohun," I " presented to the General Assembly of 1824 the petition and memorial which first directed the attention of the Church of Scotland to British India as a field for missionary exertions, on the plan that is now so successfully following out, and to which this eminently gifted scholar, himself a Brahman of high caste, had specially annexed his sanction. . . Rammohun Roy was himself a hearer in the Scotch Church of Calcutta." To the minute of St. Andrew's kirk-session on the subject Rammohun Roy appended this singular testimony on the 8th December, 1823: "As I have the honour of being a member of the congregation meeting in St. Andrew's Church (although not fully concurring in every article of the Westminster Confession of Faith), I feel happy to have an opportunity of expressing my opinion that, if the prayer of the memorial is complied with, there is a fair and reasonable prospect of this measure proving conducive to the diffusion of religious and moral knowledge in India." But, in reality, Dr. Bryce's scheme was one for almost everything that Duff's was not. His plan of a "Scottish College" was dictated by sectarian hostility to the Bishop's College of his rival, Dr. Middleton.** His proposal condemned schools for "the lower and illiterate classes of the Hindoos" as strongly as the Abbé himself had done, and urged

- See Memorial and Petition, at page 284 of his Sketch of Native Education in India. 
"addressing the better informed natives at this capital in their own language, and from under the roof of an established Christian temple, and under the sanction and countenance of an established ecclesiastical authority." The secular ecclesiastic desired, in fact, to create such a college for himself " by the maintenance of two or mor's probationers or clergymen of our Church, under the ecclesiastical superintendence of the kirk-session of St. Andrew's Church, to be educated under their eye in the native languages of the country, and employed under their authority, when duly qualified, to preach, from the pulpit of St. Andrew's Church, to such native congregation as might attend their ministry."

Dr. Inglis and the General Assembly of 1825 were less informed as to the actual state of society in Bengal and Calcutta than their chaplain on the spot, but, being free from his ecclesiastical vanities and enmities, they drew up a much wiser plan, though one still far' from adequate to the needs and opportunities of India at the time. They pronounced it desirable to establish, in the first instance, one central seminary of education, with branch schools in the surrounding country, for behoof of the children of the native population, under one who ought to be an ordained minister of the national Church, and not less than two assistant teachers from this country. That General Assembly re-appointed the committee of Dr. Inglis upon the propagation of the gospel abroad as a permanent body, with power to raise funds and select masters. It ordered an extraordinary collection in all churches and chapels for the purpose, thus adding to the "great schemes" of the Kirk, or the Highlands, the Home and the Colonial, the fourth and greatest of Foreign Missions. And on April 26th Dr. Inglis, as convener of the new committee, issued a letter " to the People of Scotland," 
apologising for "our forefathers," since perchance their utmost exertions were not more than sufficient for establishing themselves and their posterity in the liberty wherewith Christ hath made us free; pointing to the recent missionary efforts of other religious communities, and summoning the nation in the name of the General Assembly to do its duty. Appealing to the facts stated in the fifth report of the Calcutta School Book Society, founded in 1817, and in the "History of Calcutta Institutions," by Mr. Charles Lushington, one of the secretaries to Government, the national letter mentioned schools for the education in English of natives of both sexes, and colleges to train a more select number to be the teachers and preachers, as the best means for sowing a great spiritual harvest which may " be reaped by the establishment of the Redeemer's kingdom over the extensive regions of Asia. Yet let it not be inferred from our having said so much about schools and other seminaries of education, that we for a moment lose sight of the more direct means of accomplishing our object, by the preaching of the gospel to the heathen world. - . It is in subserviency to the success of preaching that we would, in this case, devote our labour to the education of the young." The whole letter, and especially the evangelic note of the predicted triumph with which it closes, show the same spirit which eight years before had preached, but with necessarily less information, of the ultimate and universal prevalence of the Redeemer's kingdom. But though the aims and the proposals of Dr. Inglis were very different from those of Dr. Bryce, we shall see how far both fell short of the genius of the first missionary, who refused to be fettered by any conditions.

With the exception of the Campbells of Argyll, and, for a time, those of Breadalbane and the Stuarts of 
Moray, the peers of Scotland have been so schlorn in their proper places as the natural leaders of the people, that it is pleasant to be able to record the part taken in the foundation of its India Mission by the Haddington branch of the ducal house of Hamilton. The ninth earl, when still Lord Binning and one of the commissioners of the old Board of Control, used all his official influence to encourage Dr. Inglis in his efforts for the Christian education of the natives of Bengal. The harmony of the Church and the Board in measures for the good of India, was not disturbed, as was too often the case in other reforms, by the Court of Directors, for Charles Grant was then supreme in influence with the "chairs." Lord Binning had at this time made the acquaintance in Rome of the young Bunsen, "for whom he has a great liking and value," says the Baroness of her husband, and he was afterwards Lord Lieutenant of Ireland.

Alexander Duff's answer to this letter to the people of Scotland was to give himself--not, indeed, to the new committee for a time, but to the Master, to bo used as His minister wherever among the Gentiles $\mathrm{He}$ might send him. But all his sympathies were with the natives of India. "It was," he long afterwards told his converts when bidding them a life-long farewell, "when a student at college, in perusing the article on India* in Sir David Brewster's "Edinburgh Encyclopædia," that my soul was first drawn out as by

The article is a wonderfully elaborate and intelligent perform. ance for that time. In a handred double-column quarto pages the writer, Mr. Stevenson, librarian of the Treasury, writes the bistory, describes the rise and progress of the European establishments, states the geographical and statistical facts, pictures the Hindoo religion, social institntions and languages, and cluses with details of the population of Bengal and Calcutta. The whole article is worthy of the work in which Thomas Carlyle began his literarr career 
a spell-like fascination towards India. And when, at a later period, I was led to respond to the call to proceed to India as the first missionary ever sent forth by the Established National Church of Scotland, my resolution was, if the Lord so willed it, never, never to return again."

Session after session, as he had returned from the winter's study at St. Andrews to the quiet of his Grampian home, the student had delighted his parents with details of his doings. John Urquhart had always been first in his talk. Especially had his father been struck with admiration at that student's determination to be a missionary to the Hindoos. In 1827 the usual budget of intelligence was produced, but as the parents hung on their son's revelations, now with tears, now with smiles, and ever with thankfulness and pride, the loved name of his Jonathan was not once mentioned. "But what of your friend Urquhart?" at last exclaimed the father. "Urquhart is no more," said Duff with the almost stern abruptness of self-restraint, and then slowly, wistfully added, "What if your son should take up his cloak? You approved the motive that directed the choice of Urquhart; you commended his high purpose- The cloak is taken up." Mother and father were awed into silence at this, the first breaking to them, or to mau, of the vow that had already been made to God.*

So the missionary mantle fell in circumstances very unlike Elijah's and Elisha's. He knew that they had

Our anthority for this most significant anecdote is the Rev. and now venerable Andrew Wallace, long minister of Oldhamstocks, who bas extracted the facts from a diary written while Duff's parents were still alive. In præ-railway days, on a journey from Ha wick to Edinburgh, his companion on the top of the coach pruved to be a Highlander from Moulin, who, having lived in the house next to Duff's, and loving him much, told Mr. Wallace the story. 
set their heart upon his being a minister in the High. lands, and that he had a prospect of not being long without a parish. He had therefore considered, before God, what his course of duty should be towards them, and had come to the conclusion that he ought to have no dealings in such a matter with flesh and blood. Moved chiefly by what he afterwards termed the grand utterance of Christ, "If any man love father or mother more than $\mathrm{Me}$ he is not worthy of Me," Duff thus anticipated all remonstrance. At first they were overwhelmed, in spite of all the father's early teaching on the various mission fields, and especially that of India; for they were parents wisely proud of their student son's reputation, and fondly indulging in the prospect of his settlement near themselves. But calm reflection brought them to acquiesce in the deliberate choice and solemn announcement of the young evangelist as the will of God, and they lived to rejoice in the surrender of themselves and their boy.

The case of India came rery close to him when, during the subsequent session of 1827-28, Principal Haldane laid before him a letter from Dr. Inglis, who had, thus far, been unsuccessful in inducing any minister or preacher of the Church of Scotland to offer himself for Calcutta, although students like Nesbit and Wilson were preparing to be sent out to Bombay by the Scottish, and others by the London Missionary Society. Dr. Haldane prononnced the third year's student of theology precisely the man that the Church's committee wanted. But Duff declined, from his youth and inexperience, to commit himself to any definite station until his studies were completed. A year after, in the spring of 1829 , the proposal was again made to him; this time by Dr. Ferrie, Professor of Civil History, and minister of Kilconquhar. He thus turned for counsel to Dr. Chalmers :- 
“St. Andrews, 12th March, 1829.

"Rev. and Dear Sir,-In redemption of a pledge formerly given, and encouraged by your kind reply, I should now endeavour to communicate whatever local intelligence can be collected since the writing of my last letter. But I trust that, though such communication be deferred for the present, I will be exonerated from the charge of neglect, by a desire to make known without delay the following particulars. Unexpected as they are in their nature, and deciding, as they appear to do, my future destiny in life, I trust you will excuse their exclusive egotism.

"About three weeks ago I was sent for by Dr. Ferrie, who stated that he had received a letter from a cousin of his, asking his advice as to the propriety of going out to superintend the Assembly's scheme for propagating the gospel in India, and that he dissuaded him from going, for, although he was satisfied as to his piety and zeal, yet he knew he wanted several other qualifications that were indispensably necessary. Immediately, he said, I occurred to him as a person vell fitted for such a sacred and important station, and accordingly he made the proposal to me of going to India to take charge of the new establishment. A proposal so weighty was neither to be precipitately rejected, nor inconsiderately acceded to. I therefore assured him I would solemnly deliberate on the measure, would wait for more definite information regarding its precise nature, and in the meantime would make it the subject of prayer. On the subject of missions in general, I have read much and thought much, and in regard both to the sacredness of the cause and the propriety of personal engagement, my mind has long been entirely satisfied; nay more, on often revolving the matter, a kind of ominous foreboding mingled so constantly with my thoughts, that 
it became an almost settled impression that the day was not far distant when I would feel it to be my duty to adopt the decisive step of devoting my life to the sacred cause. In these circumstances and with these feelings nought remained in the present instance but to inquire, seriously and prayerfully to inquire, - whether do I consciously feel myself possessed of the qualifications necessary to constitute the true mis. sionary character?' and 'whether can I accept of the offered appointment, unactuated by any but the proper motives, a desire to promote God's glory and the welfare of immortal souls?' Now, were this a matter which required merely human consultation or advice, you, my dear sir, are the tried friend on whose readiness in giving advice, as well as its soundness when given, I could most confidently rely. But I hope that I acted in accordance with your views, when I concluded that the present inquiry rested almost solely between myself and my Maker. With this view of the case and in this spirit the inquiry was certainly conducted. And the result was, that, weak as is my faith and secularized as, I must confess, are all my desires, I yet felt I could find it in my heart to devote myself to the service of the Lord, undivided by any worldly tie and uninfluenced by any mercenary motive.

"The inquiry as to the motives being brought to this conclusion, at which may the Lord grant that I have not arrived through any self-deception, the other inquiry, respecting the requisite qualifications, was by no means concluded so much to my own satisfaction. But on further reflection on the subject, the exceeding precious promises of God appeared to rebuke my distrustful vacillating spirit; and I seemed to have the faith-I trust it was not the presumption-to conclude that, if I engaged in the work with full sincerity of soul, by faith accompanied with prayer, God's grace 
might be sufficient for me, and His strength might be made perfect in my weakness. In this frame of mind, therefore, I resolved, if offered the appointment, to accept of it. This offer was not long in being virtually made. On Wednesday, last week, Dr. Ferrie received a letter from Dr. Muir (Dr. Inglis, the convener of the committee, being unwell), which among other things contained the following clauses: 'Dr. Inglis intimated his earnest desire to know from you as soon as possible what may be the determination of Mr. Duff. The Doctor is satisfied by all you have said that he is the very person fitted for the important purpose, and he is therefore extremely anxious to receive Mr. Duff's decision on the side of the offer; as he is not able to occupy himself with the routine of ordinary duty, his mind is exercised with almost a keen feeling of anxiety on the Indian scheme. If you can write to me soon, and especially if you can send me any encouraging intelligence from Mr. D., your letter on the subject will be very acceptable to him.' From this you perceive that the offer was fairly laid at my door, and that a definite answer was required as soon as possible. And having already made up my own mind on the subject, I lost no time in visiting my friends, in order to justify to them a conduct to which I knew they would feel a strong aversion. I have now returned, after haring succeeded in securing their concurrence, and have thus endeavoured to present you with a brief statement of all that has transpired.

"I am now prepared to reply to the committee in the words of the prophet, 'Here am I, send me.' The work is most arduous, but is of God and must prosper ; many sacrifices painful to 'flesh and blood' must be made, but not any correspondent to the glory of winning souls to Christ. With the thought of this glory I feel myself almost transported with joy; everything else appears to 
fall out of view as vain and insignificant. The kings and great men of the earth have reared the sculptured monument and the lofty pyramid with the vain hope of transmitting their names with reverence to succeeding generations; and yet the sculptured monument and the lofty pyramid do crumble into decay, and must finally be burnt up in the general wreck of dissolving nature; but he who has been the means of subduing one soul to the Cross of Christ, hath reared a far more enduring monument-a monument that will outlast all time, and survive the widespread ruins of ten thousand worlds; a trophy which is destined to bloom and flourish. in immortal youth in the land of immortality, and which will perpetuate the remembrance of him who raised it throughout the boundless duration of eternal ages.

"But I am wandering, and have almosi forgotten that I am writing a letter and not a discourse. I trust, however, that you, who know human nature so well, will grant me every indulgence when you take into account the present freshness and excitation of my feelings. My heart is full ; would to God that it continued so, as out of the abundance of the heart the mouth speaketh! As the active members of committee seem to have formed a favourable opinion of me, anything which you may feel yourself entitled to say calculated to confirm that opinion, or any opportunity which you may have it in your power to take of making known my sentiments on the present important subject, will be viewed as a token of kindness, surpassed only by the many already experienced at your hands, most undeserved on my part. But I am almost disgusted with this continued tissue of selfishness, and must endeavour to atone for it in my next communication. Please present my kindest regards to Mrs. Chalmers and family, and Miss Edie, and I remain, rev. and dear sir, yours with deep feelings of gratitude, Alexander DUfF." 
But he was not the man to yield himself blindly to conditions which might fetter his action in a new field, and neutralize all that was original or strong in his nature. He required to be assured, first, that he should be wholly unshackled in the modes of meeting and operating on the natives; and secondly, in particular that he should be entirely independent of the chaplains and kirk-session of Calcutta. His foresigbt in these most wise provisions proved equal to his self-devotion, and enabled that derotion to accomplish all that his genius was peculiarly fitted to attempt. Alexander Duff in trammels would have meant shipwreck of the mission. To these terms Dr. Inglis consented, and with such utter trist that the difficulty afterwards was to receive instructions of any kind from the Church. Referred in vain to Dr. David Dickson as likely, from his experience of the Scottish Society, to enter into useful details, the first missionary of the Church of Scotland went out to Calcutta with only one injunction laid upon him, which it became his duty to violate the moment he saw the country and the people for himself. That order was, not to settle in the metropolis itself but in a rural district of Bengal.

The committee had a rule, that they must formally hear a man preach before ordaining him as a missionary. Accordingly, at a week-day evening service then conducted in one of the churches into which a barbarous ecclesiasticism has divided the once beautiful Presbyterian cathedral of St. Giles, the Rev. Alexander Duff', M.A., licentiate of the Kirk, preached his first sermon, before Dr. Inglis and Dr. Andrew Thomson, representatives of the two great parties in the Church, and the only members of committee present. The text was that word of St. Paul, in which he and all his true successors have planted the missionary standard, from Corinth west to Columba on 
Iona, and east to Duff in Calcutta: "I determined not to know anything among you save Jesus Christ and Him crucified." Mr. Duff breakfasted with Dr. Chalmers on the morning after the great orator had made that emancipation speech which carried not only Edinburgh but the whole country by storm. Of this speech the Duke of Wellington, then Prime Minister, caused 105,000 copies to be printed and circulated throughout the country. At that time also the reprint of Baxter's " Reformed Pastor" had appeared, forming one of the series of Collins's Select Christian Authors, with the introductory essay by Bishop Wilson of Calcutta, then Daniel Wilson, vicar of Islington. Dr. Chalmers had just finished the perusal of it, and said in his own blunt way, "In this essay Daniel Wilson has risen far above himself." On the same occasion there was 'a meeting of students held in one of the classrooms of the University, which Duff had the curiosity to attend. There for the first time he saw and heard Principal Cunningham, then a student of theology, speak. He was so struck with the close, compact, argumentative power of the address, that he remarked, "that man, if spared, will be sure to shine forth as a great ecclesiastical debater." 'Then, too, he received his first impressions of Edward Irving, being more than once one of the crowd who got up on a winter's morning at four o'clock to besiege the gates of St. Cuthbert's, for a place to hear Thomas Carlyle's inspired friend, whom he pronounced worthy of his marvellous reputation.

The report read by Dr. Inglis to the Assembly of 1829 , buried in old records and magazines from which we have exhumed it, declared that what the committee had wanted in its first missionary was " nothing less than a combination of the distinguished talents requisite for that office (head of a college), with such dis- 
interested zeal for the propagation of the gospel as could induce a highly gifted individual to forego the prospect of a settlement at home corresponding to his merits, for the purpose of deroting himself to labour in a distant land, without any prospect of earthly reward beyond what should be indispensably necessary to his outward respectability in the society with which he was to mingle." This subsistence allowance was fixed at $£ 300$ a year and a free house, "as the least that could be reasonably proffered," in the year 1829 .

The committee then described "Mr. Alexander Duff, preacher of the gospel," whom they had found "after long-continued inquiry and much patient waiting," as "a person possessed of such talents and acquirements, literary, scientific and theological, as would do honour to any station in the Church; who also combines with these the prudence and discretion which are so peculiarly requisite in the discharge of the duties which will devolve upon him; and is, at the same time, animated with such zeal in the cause to which he devotes himself, as to make him think lightly of all the advantages which he foregoes in leaving his native land." The self-dedication of the young preacher was made a reason for a renewed appeal to the congregations of the Kirk to do their duty. Not half of themonly 400-had subscribed, and that but $£ 5,000$ in three years. "The natives of India," they were told, "are our fellow subjects, members of the same great commonwealth to which we belong, dependent upon the fostering care of the same government under which we live. Shall not this consideration find its way to the heart of a Briton? . . Our exertions for this benevolent purpose may even have the effect to sanctify, in the sight of Heaven, the government . . and to prolong, for the benefit of many generations, the interesting relation in which we stand to so large a 
portion of the human race. What would the fathers of our Church have said if, looking forward to a period of such internal peace and prosperity as it now enjoys, they could have supposed that the men who now fill their places in the world, would not even aim at participating in the high honour of being instrumental in the hand of God for promoting the enlargement of the Redeemer's kingdom on earth ?" Who shall say that the convener who wrote, and the Assembly who heartily adopted such language as that, had not a truly imperial spirit in the highest sense, Christian as well as political? The response had waited only for the man. Mr. Duff's ordination resulted in the offer, by not a few parishes, of that annual collection which, in the three temporarily severed but heartily co-operating branches of the Kirk of Scotland, has risen to a gross revenue for foreign missions of nearly $£ 100,000$ a year.

The General Assembly of May, 1829, cordially and unanimously appointed Mr. Duff their first missionary, and his ordination in St. George's followed on the 12th of August, Dr. Chalmers officiating on the historic occasion. Dr. Harper, the venerable Principal of the United Presbyterian College, still recalls the marvellous speech delivered by the new missionary, then a young man of twenty-three, on his formal designation to the East. With such force and fire, such energy and action, did the rapt enthusiast picture the work to which he was giving his life, that Dr. Harper feared he would too soon waste himself away in the heat of the tropics.

From not a few pulpits and platforms before his departure for India he delivered missionary discourses and appeals, which roused a new spirit in the country, and have left behind them, in the long half-century since they were uttered, the echo of such a burst of self-dedication as this in the fine old kirk of Leuchars, 
where, preaching from Romans i. 14, "I am debtor both to the Greeks and to the Barbarians," he exclaimed"There was a time when I had no care or concern for the heathen: that was a time when I had no care or concern for my own soul. When by the grace of God I was led to care for my own soul, then it was I began to care for the heathen abroad. In my closet, on my bended knees, I then said to God, 'O Lord, Thou knowest that silver and gold to give to this cause I have none; what I have I give unto Thee,-I offer Thee myself, wilt Thou accept the gift?" "The hearer who recalls this, adds, "I think I see him, with tears trickling down his cheeks as he uttered these words. Afterwards I walked from Dundee to St. Andrews, and went to his Sabbath school, when he gave a very affecting address to his class of young people, urging them to remember him in their prayers as he would them in his, and the same God who heard them would hear him in India."

To Mrs. Briggs and other friends who presented him with that Bagster's Bible which had afterwards so eventful a history, he wrote:- "I surely can never forget St. Andrews. Endeared by many interesting associations, and linked to my soul by the fondest recollections of kindness and friendship and Christian fellowship, it would argue a destitution of all principle and of all feeling did I ever wholly forget it. And if, amid the cares and the employments of an arduous but glorious undertaking in a foreign land, the fieshness of feeling be apt to become languid, and the vividness of memory to fade, the daily obtrusion on the eye of sense of a memorial like the present cannot fail to quicken the languishing feelings, and revive the fading impressions on the memory. What is more: the daily perusal of that blessed book, which, in its present adventitious connection, must scrve as the reviver of 
what had a tendency to decay, and the remembrancer of friends that are far distant, will invest these impressions with a sacredness, and those feelings with a hallowedness, to the possession of which they could not otherwise have any claim."

The decision of the General Assembly, and the arrangements which followed it, led him thus to address his father, who had watched with a grateful pride the consecration of the son to a higher than an ecclesiastical bishopric of souls :- "Pray with redoubled earnestness that I may be strengthened with all might in the inner man, and with all grace and all divine knowledge, that I may be enabled to approve myself a good and a valiant soldier of the Cross, and not merely a common soldier but a champion. $\mathrm{Oh}$ ! that I breathed a nobler spirit, and were filled with a more fervent and devoted zeal, and were more humbled on account of my vileness and unworthiness, and were clinging more closely to my Saviour." The natural affection of his mother he thus reasoned with: "Beware of making an idol of me. While you feel all the tenderness of parental love which the faith of the gospel, far from extirpating, strengthens, sanctifies, and refines, be earnest in prayer to God that Satan may not tempt you to raise me to an undue place in your affections, lest God, in His holy displeasure, see fit to remove me not only to India, but to the land of skulls and sepulchres. Think then, ponder, pray over these things, and may God Himself guide and direct you into the ways of peace and heavenly resignation. Your account of the people about Moulin has driven me to pray, and humbled $m e$ in the dust. . Lord, what am I that I should be so highly honoured as to be made the instrument of conveying such truths as were calculated to arouse, to awaken, to edify? Merit, is it said? No, no, had I any more than the hollowed channel 
of the river along which are made to flow those streams that enrich and fertilize the neighbouring lands?" Again when leaving Scotland he thus poured out all the sacred confidences and trust of his heart:-

“ Edinburge, 25th August, 1829.

“Mr Dear Father,-I received your gratifying letter in time to prevent uneasiness. It was truly a gratifying letter, vividly displaying the workings and resolutions of a Christian mind, as well as the feelings of a tender parent. Who sent us all our blessings? God. And shall we return His kindness with base ingratitude? shall we become more obdurate the more He showers upon us of His loving-kindness? Yes, we may, but woe unto us if we shall; we may, but heaven will frown upon us if we do, and hell will exult with joy. Come, then, let us acknowledge the goodness of God. Let us pour out our souls in praise and thanksgiving at a throne of grace. Is He not a kind God, and shall we be unmindful? Is He not a gracious forgiving God, and shall we be rebellious? Is He not a God of love, and shall we therefore hate Him and His children? Ah! What do I say? Forget, rebel against, and hate the great Creator, Preserver, Redeemer, and Judge! Oh, my soul, shrink from the impious thought; and praise God that thou art not at this moment an outcast in the place of perdition.

"This, my dear father, I believe to be the language of your heart, when you have finally resolved to deliver me up a free-will offering to the Lord. In so delivering me do reckon it to be a duty and a privilege. Instead of my being willing in this service, and preserved from the evil that is in the world, might $I$ not, at this moment, be a rake, and given up to all manner of vice, and doomed to expiate my crime against an outraged 
community on the scaffold? And would not your heart be broken and your grey hairs brought down with sorrow to the grave, if this were my unhappy destiny? Yes, my dear father, sure I am that, in this case, anguish inexpressible would be your anguish, such as alone a parent can feel. Who then has so highly favoured you and me as to save us the anguish and shame of such a death? God alone, in the riches of His restraining grace and boundless compassion. And if, on the other hand, God, with a love that is unfathomable as the abyss of His own infinity, has blessed me undeservedly, blessed me with the comforts of this life, infused into my soul a portion of His grace, taught me to look forward to a glorious heaven as my home; nay more, made my venerable parent the Church of Scotland call me, one of the unworthiest of her sons, to fight the battles of the Lord in the land of the enemy, and exhibit feats of divine heroism, and live the life and die the death of a special ambassador of the Lord to the heathen, oh! should not I rejoice, should not you rejoice and fall down on your knees, and bless and praise and magnify the holy name of God, for having so richly favoured, so highly honoured a feeble, undeserving son of yours? Or will you be a loser by so giving me up to the Lord, and so praising Him for His goodness in having called me to so mighty a work? No, God will bless you with the blessing of Abraham, will enrich you with His faith and reward, and will reward you a thousandfold for your willing resignation and cheerful readiness in obeying God's command. The Lord bless you, and my dear mother, and all the people of God at Moulin. Adieu! Your dear and affectionate son,

\section{"Alexander Doff."}

The student who seems to have taken the place of 
Urquhart in his affections was one of his own age, but several years junior to him in college. To David Ewart, also a Perthshire man but born at Alyth, he thus describes his preparation in Edinburgh for the work which he had undertaken. The glowing language and utter self-surrender doubtless influenced his friend to follow him after some years to Calcutta :-

“Edinburah, 8th July, 1829.

“My Dear Mr. Ewart,-In redemption of a pledge given at our last parting I now write to you. At present my time is chiefly occupied in inspecting the best conducted schools in this city, in writing discourses for my ordination-trials, etc., and in studying the religion and character of the Hindoos, so far as a knowledge of these can be acquired from books and the information of gentlemen who have been in India; my object being, under the divine blessing, to employ every means that may conduce to render myself more fully qualified for satisfactorily fulfilling the arduous duties which I have undertaken to discharge. To imbue these dead exercises with the living energy of heaven, and convert them into usefulness in the service of heaven, I endeavour feebly and imperfectly, yet, I trust, earnestly and incessantly, to pour out my soul in prayer and supplication to the Father of spirits, that $\mathrm{He}$ may cause His richest blessings to descend upon my feeble efforts. I have endeavoured to examine into the state of my soul, to prove the sincerity of my motives in my self-dedication to the cause of Christ. I have endeavoured not only to subdue, but absolutely to crueify and annihilate, that fair and plausible and insinuating but withal hell-enkindled and soul-destroying thing, self: I have endeavoured to count the cost and view it in its most fearful magnitude: I have 
endeavoured to ascend the mountain of the Lord, to enter His holy temple and presence, to lay hold of the balances of the sanctuary. In the one side I have placed the clinging ties and lingering claims of the land of my fathers, the fond caresses of friends and acquaintances dear as life, the refined enjoyments of civilized society, the delights arising from favourite studies, and the exbilarating benefits of a kindly climate : in the other, the unredeemed cheerlessness of a foreign land, the scorn and contempt and ridicule of the strangers for whose welfare I labour, the grating inconveniences of a rude untutored community, the engagements in studies and pursuits inherently unwelcome to the mind, and the enervating, destructive influences of an unwholesome atmosphere; dangers, difficulties, disappointments, yea, the great probability of a sudden, premature death :-these have I, in dependence upon divine grace, endeavoured to weigh in the balances. The former side, notwithstanding its apparent weight, has been found wanting; the latter God has been graciously pleased to cause uniformly to preponderate. And in the glow of a feeling which is not natural to flesh and blood, and which, from its permanence, cannot be the offspring of a heated imagination, I have been enabled to exclaim : 'May the former considerations not only be weakened, but be utterly swept out of existence. 0 Lord, I feel their littleness, their total insignificancy, and, for the sake of promoting Thy glory among the heathen, I cordially, cheerfully embrace the latter: yea, if such were Thy will, I am ready to go to the parched desert or the howling wilderness, to live on its bitter herbs and at the mercy of its savage inhabitants. Lord, strengthen the weak. ness of my faith that I may be powerful in accom. plishing Thy will.' . . Your affectionate friend, 
Next to his own people, none took so keen an interest in the whole career of the young missionary as a patriarchal couple at Blairgowrie, who, being childless, had long devoted themselves exclusively to work for Christ. Patrick Lawson and his wife became young again when they had students around them; and few were so welcome as Alexander Duff, who had been in the habit of visiting them annually, on the rising of the college, attracted chiefly by their rich and racy biblical talk. In his last interview, after his appointment by the General Assembly, he was asked abruptly whether he intended to marry. He replied that he had been too close a student to think of such matters, and had not, up to that time, met one whom he could conscientiously regard as a suitable helpmeet in so arduous an enterprise. "Well," said the old gentleman, steadfastly regarding him, "I do not approve of young men fresh from college taking wives to themselves when newly married to their church, before they can possibly know the requirements of their work. But your case is wholly different. You go to a distant region of heathenism, where you will find little sympathy among your countrymen, and will need the companionship of one like-minded to whom you may unbosom yourself. My advice to you is, be quietly on the look-out; and if, in God's providence, you make the acquaintance of one of the daughters of Zion, traversing, like yourself, the wilderness of this world, her face set thitherward, get into friendly converse with her. If you find that in mind, in heart, in temper and disposition you congenialize, and if God puts it into her heart to be willing to forsake father and mother and cast in her lot with you, regard it as a token from the God of providence that you should use the proper means to secure her Christian society." Thus he went on, in the allegorical style of Bunyan, 
and with a deep feeling which speedily won Mr. Duff's assent.

Just before Dr. Chalmers ordained the missionary, Dr. Inglis married him to Anne Scott Drysdale, of Edinburgh. It was, and was more than once pronounced by him, when left the survivor but not solitary, a happy consummation. Never had even missionary a more devoted wife. Sinking herself in her husband from the very first, she gave him a new strength, and left the whole fulness of his nature and his time free for the one work of his life. She worthily takes her place among those noble women, in many lands of the East, who have supplied the domestic order, the family joy, the wedded strength needed to nerve the pioneers of missions for the unceasing conflict that ends in victory.

It was on the 19th September, 1829, that the missionary and his wife left Leith for London, where they became the guests of Alderman and Mrs. Pirie, and where Mr., afterwards Sir John Pirie, secured a passage and fitted up a cabin for them in the Lady Holland East Indiaman. Dr. Inglis had formally applied to the Court of Directors for that permission for Mr. Duff and his wife to sail to India as "interlopers," not in the covenanted civil, military and naval service of the East India Company, which passport Parliament was soon to declare unnecessary by the liberal charter of 1833. He was, Dr. Inglis reported to the Assembly of 1830, "supplied with letters of introduction and recommendation to the GovernorGeneral, to our countryman the Earl of Dalhousie, to other men of influence at the seat of Government at Calcutta, and to some of our private friends." The Earl, who was Commander-in-Chief of the Indian armies, was the father of the great Marquis, and the Governor-General was Lord William Bentinck. This 
was the letter to the Calcutta chaplain. Dr. Bryce and his wife in due time welcomed Mr. and Mrs. Duff with the proverbial kindliness of Anglo-Indians.

"Edingorge, 16th September, 1829.

"Mr Dear Sir,-This letter will be delivered to you by Mr. Alexander Duff, who is, at length, sent out as Head Master of the General Assembly's proposed Institution in India. I need not say much for explaining to you the causes of delay in the accomplishment of an object which I have had much at heart. Want of money will readily occur to you; and it was in fact the only impediment. But we now hope that we may venture to send out one assistant to Mr. Duff, who may reach him pretty nearly as soon as he shall have made all the requisite preparations for the work assigned to him.

"I have great confidence in Mr. Duff for an able and faithful and prudent discharge of all the duty which he has undertaken. At the College of St. Andrews, where he was bred, he stood very high in respect of attainments-literary and scientific as well as theological; he carried off many of the first prizes in every department. At the same time his whole heart seems to be committed in the work which he has nndertaken; and we have had the strongest attestations of the prudence and discretion of his general conduct.

"As to his side in the Church I have made no inquiry. It was obvious from the beginning that this was not a point to be insisted on. But he has been recommended to me by men of both sides of the Church in language equally strong. I have no doubt of his experiencing from you all the kindness which my heart can desire; and I am confident that my friend Mrs. Bryce will have an equal disposition to show kindness to Mrs. Duff. With her I am littlo acquainted; but it would give me much pleasure to learn that she proves an agreeable accompaniment of our mission to India.

"Many thanks to you for what you did in procuring contributions to our fund. I received notice from Dr. Meiklejohn and Mr. Peterkin that they amount to about $£ 1,000$, lying in a bank at Calcutta, and bearing interest at the order of the General Assembly. I received a similar intimation that 3,350 rupees were lying for us at Bombay. An order will be sent 
through the house of Coutts \& Co., in London, for the payment of both the Calcutta and the Bombay money to their correspondent in Calcutta, who will be empowered to dispose of it, for behoof of the Assembly's Committee, in the payment of salaries, etc., as circumstances shall require.

"I must refer you to Mr. Duff for an explanation of all our plan, which has been arranged in the course of consultation with your excellent friend, Dr. Macwhirter. In truth, the want of money seems to be the only thing that stands in the way of a fair prospect of great success. This want I shall do everything in my power to supply; and I am very hopeful that yon will now find it in your power to assist me farther with your friends in India. In this case we should be able very soon to complete what has been proposed by having, besides the head-master, two assistant-teachers from Europe, and as many native teachers as they can conveniently superintend. I shall now be very anxious to hear from you about what is doing after Mr. Duff's arrival. The precise site of our Institution will be an important object to fix. All that we have determined here is that it should be in the neighbourhood of Calcutta."

The missionary's last letter from London was addressed to Dr. Chalmers :

\section{"6th October, 1829.}

"Dear Doctor,-I cannot make a sufficient acknowledgment to you for your kindness in forwarding to me a copy of your charge. No boon could be to me so invaluable, no address equally pregnant with sound advice and eloquent admonition. Major Carnac, to whom you so kindly introduced me, I found truly agreeable and ready to promote my views. By Mr. Orme I was last week introduced to a full meeting of the directors of the London Missionary Society, who received me with the most marked attention; and in private I have reaped much benefit from the conversations of Mr. Townly, Dr. Henderson, and Mr. Hands. 
I have attended Mr. Forbes for the acquisition of oriental languages. My kindest respects to Mrs. Chalmers and family, and Miss Edie. This evening we set off for Portsmouth." 


\section{CHAPTER III.}

1830.

\section{THE TWO SHIPWRECKS.}

"In Perils of Waters."-The Lady Holland and her Passengers -Lientenant H. M. Durand.-Madeira.-The Unfortunate Ball. - Captain Marryat.-George Canning's Eldest Son.-Pirates.Cape Verd Islands.-Off Dassen Island.-The First Shipwreck. -Anticipations of the Day of Judgment.-Resignation and Prayer.-Saved at Last.-The Bible and Psalter cast up by the Sea.-Fervent Thanksgiving of All.-Lesson from the Lost Library.-Cape Town.-Letter to Dr. Chalmers.-Mr. and Mrs. Duff sail in the Moira for Calcntta.-Opposing Gales.-At the Sandheads.-Cyclone off Saugar Island.-The Second Shipwreck. -A Night and Day of Storm.-The Missionary and his Wite thrown on the Shore of India.-A Day and Night in a Temple. -Welcomed at Calcutta.-Adam and Lacroix.-Lord and Lady William Bentinck.-Superstition of the Natives forecasts Duff's Future.

The vision of judgment seen by the child who had been feeding his fancy on the Gaelic rhapsodies of Dugald Buchanan; the divine call to the boy as he lay dreaming among the blae-berries on the streamlet's bank; the deliverance of the youth by the flare of a torch when he and his companion were falling into the sleep of death, lost amid the snowdrifts of the Grampians-these foreshadowings were not to cease until the missionary's preparation for his work was completed. He had followed the monition of all three, not blindly, but as explained by John Urquhart's death-consecrated appeal, by Dr. Haldane's apparently premature invitation, by Dr. Ferrie's appropriate demand that he should offer himself for 
Calcutta, by Dr. Inglis's approval, by the General Assembly's appointment; and, finally, by ordination at the hands of the Presbytery, amid the crowd that filled St. George's, Edinburgh, and after the inspiriting eloquence of Dr. Chalmers. Alexander Duff and his wife were still to undergo the experience of the greatest of all missionaries who wrote, "Thrice I suffered shipwreck, a night and a day have $I$ been in the deep, in journeyings often, in perils of waters."

The East India Company's ship Lady Holland, having filled up in the Thames with a cargo valued at $£ 48,000$, entered the Channel, shipped her passengers at Portsmouth, became windbound for a week at Spithead, and finally set sail from Ryde on the 14th October, 1829. Plunging heavily into the storm outside the Isle of Wight, the ship made for Falmouth. When the gale had abated she passed close to a derelict vessel carrying wood and swept desolate by the waves. Not a trace of the crew could be found. The sight affected the Lady Holland's passengers and crew, filling not a few with ominous apprehensions as to the issues of a voyage thus begun. But the dreaded Bay of Biscay proved to be unusually friendly, although contrary winds did not allow the ship to reach the roads of Funchal till the 7 th of November. By that time the twenty-two passengers had taken stock of each other. The great man on board was no higher than a judge in the Madras civil service; but it was a fortunate circumstance that Mr. Lascelles and his party of seven proved to be "decidedly pious," as described by Mr. Duff in a letter to Principal Haldane. An eighth, and next to Duff himself the most remarkable man on board, was Henry Marion Durand, the young lieutenant of Engineers who was to come second only to Sir Henry Lawrence on the brilliant roll of the Company's soldier-statesmen. He 
made up a gathering of at least ten who attended daily worship.*

The captain, as usual, had intended to remain a week at Madeira, to take in a cargo of wine that it might make the voyage to India to be mollowed for the English market. Anticipating this Alderman Pirie had provided for the hospitable reception of Mr. and Mrs. Duff by his agent, Mr. Stoddart, who was one of the principal merchants and afterwards British Consul. As there were at the time three British frigates in the roads, they found their fellow-guest to be the famous novelist, Captain Marryat, who was in command of one. The week had nearly passed; the agent of the ship gave the usual ball to the captain and passengers on the night before her announced departure, and all were present at the dance save the Duffs and Lieutenant Durand. After midnight westerly gales set in with violence and drove the ships in the Bay out to sea. Three of them missed stays, were driven ashore and dashed to pieces, and not a life was saved. The captains of the frigates and other vessels, being on shore at the ball, were in a very sorry plight. Day after day there was a succession of gales, so that nothing was heard of any one of the vessels for upwards of three weeks. We may imagine the position of those passengers who had gone ashore in their ball-dress with no change of garments. Despairing of the vessel some of them began to negotiate with a Portuguese ship about to proceed to Lisbon, that they might thence go to London and take out a new passage.

Being thus unexpectedly detained upwards of three

* The life of Sir Henry Durand, the noblest member of the ducal house of Northumberland, is bcing written by his second son, who is of the Bengal civil service. 
weeks beyond the allotted time, the passengcrs in the different parties visited the most interesting sights of the island, amongst others the Curral, in the centre, which is in reality the gigantic crater of a volcano rising to the height of six thousand feet. Approached by a difficult zigzag path along many precipices which look down upon a tremendous chasm, the Curral was not seen till they actually reached it. At the first sight of its vast dimensions, in breadth as well as height and depth, all were struck dumb by a sensation of the sublime. The appearance of the place suggested to Mr. Duff the well-known lines of Cowper,-

\section{"Higher than the heights above, Deeper than the depths beneath, Free and faithful, strong as death,"}

which he could not help repeating aloud. During his stay he also inspected some conventual and monastic institutions, making inquiries into the practical working of both. At that time Don Miguel had usurped the throne of Portugal, and had seized the Portuguese fleet, which he sent to Madeira to capture the island, to expel the Constitutionalists, and to proclaim his own sovereignty over it. Such was the ignorance of the inhabitants, that the priests succeeded in making them believe that Miguel was the incarnation of the archangel Michael; and their professed belief or non-belief in this impudent dogma was constituted into a test to distinguish between the Miguelites and the Constitutionalists.

A little before this time the eldest surviving son of the great George Canning had been there in command of an English frigate. Animated by the liberal principles of his father, he made it to be understood that, though he could not officially interfere, if any of the persecuted Constitutionalists chose to seek refuge 
on board his ship he would receive them. In time it was known to the Portuguese authorities that he had upwards of three hundred of these on board, and the Governor of the island and the Admiral of the Portuguese sent him a message to the effect that if he did not deliver up the refugees, whom they reckoned traitors, they would blow his frigate in pieces. This they could have done, but young Canning, with the spirit of the British seaman, always replied, "No, never; I will deliver up not one of them, and you may blow my ship in pieces if you like, but that will only precipitate your own doom, as it would send forth the English Navy to put an end to you utterly." In point of fact they did not meddle with him. A good way up the hill a retired merchant of the name of Gordon resided in a house beautifully situated. He was a very humane man. He had got himself appointed conservator of animals, so that he was constantly on the look-out for cases of cruelty to be punished. It was a real instance of benevolence of natural instinct. He was also very hospitable. One day Captain Canning went up the hill to the house, in front of which was a tank of fresh water. Being greatly heated he threw off his clothes, plunged into the tank, was seized with cramp, and never came out alive. Thus perished one whose younger brother became the first Viceroy of India.* Among the Constitutionalists there was throughout the island universal lamentation.

Mr. Duff held Sabbath services in the hall of one the boarding-houses, which were attended by most

- Shall we never see a memoir of Charles John Earl Canning, K.G., and his more noble wife: Their name seems likely to perish most nuideservedly, absorbed in that of the De-Burghs or Burkes, of whom is their nephew, the Marquis of Clanricarde. 
of the English people in Funchal; and there was no hearer more attentive than Captain Marryat, who used to boast that one of his ancestors was a martyr to the Christian faith. After three weeks one and another of the missing ships began to return, and on the 3rd December the Lady Holland set sail in company with one of the British frigates wbich had been ordered to the equatorial regions to look after pirates. This necessitated a détour to the port of the principal of the Cape Verd islands, where the captain of the frigate had to consult the British Consul, and learn from him all that was known about the proceedings of the pirates. There the ship was again detained a week. At that time the islands, instead of realizing what their name implies, were suffering from longcontinued drought, so that everything on the surface was literally burned up.

One morning, within a few hundred yards of the vessel there passed, scudding before the wind, one of the famous pirate ships with at least fifty men on deck, and the British frigate in full pursuit. The Lady Holland, thus saved from what otherwise would have been destruction to passengers and vessel, rapidly proceeded on her voyage, leaving the frigate to deal with the pirate. After having been driven by the south-east trade-wind very near to the coast of Buenos Ayres, she at last, early in February, approached the coast of South Africa, for the captain intended to call at the Cape of Good Hope. For a whole week the weather had been cloudy and boisterous, so that no accurate observation could be obtained as to the position of the ship; still, the captain knew that he was within no great distance of the coast. Three times, by contrary winds, he was driven considerably to the south of Table Bay, and returned with the view of going into it. 
From the Cape coast there shoots out into the sea, for forty or fifty miles, a sandbank on which soundings may be had, but along which a tremendous current sweeps round from the Cape. By soundings, on Saturday evening, 13th February, the captain knew that he had entered on this bank. His intention, therefore, was to avoid risks by turning his vessel back to sea about eight o'clock. But having then sounded, his conclusion was that he might safely go on for other two hours, and his fixed determination was by ten o'clock to turn back or heave to and stay till morning. But as four bells announced ten o'clock, and he rose to give the order to turn the vessel back, she bumped with alarming violence upon rocks. The concussion was tremendous, and from the first moment her case seemed hopeless. It was not upon a precipice, but on reefs of rock over which the waves and billows dashed furiously, so that at once her back was broken and the fore part sank down between the reefs. As in all East Indiamen in those days lights were put out at ten, almost all the passengers had retired to their berths. The violent collision, as it seemed, at once roused them up, and they rushed to the cuddy, wrapped up in blankets, sheets, or whatever they could lay hold of. Occupying one of the backmost poop cabins, Mr. Duff was half undressed when the shock took place. . He ran out into the cuddy, crossed the cabin, met the captain on the deck, and heard him exclaim in agony, "Oh, she's gone, she's gone!"

Seeing that the condition of the vessel was hopeless, the command was promptly given to cut down the masts in order to relieve the pressure of the wind on the sails, and then, in case there might be a way of escape, to caulk the seams of the long-boat, which was in the centre of the vessel, and in which were forty sheep when it left Eng- 
land. Meanwhile almost all the passengers assembled in the cuddy, but, from the violence of the motion, they could neither sit nor stand without clinging to some object. At first consternation was depicted in every countenance at the suddenness of so terrible a catastrophe, for all had joyfully made their arrangements to go on shore at Cape Town next forenoon. In one of the cabins adjoining the cuddy there was a captain who was heard crying out in bitter agony, "What shall become of me, I have been such a hypocrite!" The explanation of this was, that he had been married to a godly lady, and while she lived he tried to pay at least outward homage to the observances of religion, but, after her death, he relapsed into the follies of the world. Mr. Duff was wont to hold a religious service every Lord's-day, which all the passengers attended except this officer, who, to show his contempt used to pace the poop deck over their heads. One of the ladies, who was a Christian, happened to notice that another of the passengers, a colonel who occupied one of the poop cabins, was not among the number present, and her remark was, "Let us not allow him to go down without at least his knowing it." Two or three entered his cabin and found him profoundly asleep. Waking him up, they dragged him into the cuddy. Astonished he began to cry out, "Are you all crazed?" and then he suddenly broke out into a bacchanalian song. This surprised every one, because it was not known that he could sing at all. He was naturally a most affable and courteous man, who was a general farourite with the passengers. But it turned out that he had a habit, unknown to most of them, of nightly taking a very copious draught of brandy, and then retiring to his berth. Having slept it off, the next morning he would appear cheerful as usual. The disaster having taken 
place about ten o'clock, there had not been time for him to recover from the effects of the draught.

A few of the passengers were God-fearing people, and they were calmly resigned to what seemed to be their inevitable fate. As was often the case in these long voyages, several of them were not even on speaking terms. To introduce a mollifying element, $\mathrm{Mr}$. Duff was accustomed daily to have a number of them in his cabin, to whom he read portions of the history of India and other works. Now all, oppressed with the conviction that they might immediately appear before the judgment seat of God, became suddenly reconciled, shaking each other by the hand and imploring forgiveness. Others thought of the friends whom they had left at home, and gave varied utterance to their feelings. The whole scene, Mr. Duff used to say afterwards, tended to suggest the marvellous revelations which shall take place at the Day of Judgment. In about half an hour, when the first convulsive agonies of feeling began to abate, he suggested that, as all might suddenly be called together to give their final account, they should join as best they could in prayer to God for their deliverance, if it were His holy will, and if otherwise that they might be prepared to meet Him. All responded, clustering around him and holding by what objects they could, while the missionary poured out his soul in fervent supplications.

While such was the scene below, the captain and the sailors were eagerly doing their part on the deck. All around the wreck there was one mass of white foam, except immediately behind. The captain had, at the very outset, ordered one of the gig boats hanging over the side of the vessel to be launched. $\mathrm{He}$ put three seamen into her, with the order to follow this darker part, and, if possible, get round the mass of white foam to ascertain whether there was 
any landing place available. For, at the time, it was not known whether the vessel had struck on a sunken reef, on an island, or on the mainland. It was a desperate endeavour. The sea was running mountains high, and it seemed impossible that a small boat could live in it. Three hours had passed and the boat was given up as lost, when it appeared and the seamen announced that, round the mass of white foam, they had found a small sandy bay, on which, if it could be reached, a landing would be practicable. This intensified the desire to launch the long-boat, but, surrounded as the wreck was by masts, spars and broken bulwarks, it seemed more than doubtful whether this could be doue. Every wave was now rolling over the main deck.

At last, watching their opportunity, the sailors got the boat afloat by the help of one of the waves. When they saw it fairly off at a short distance from the wreck, they raised the shout, "There goes our last hope," meaning, there it is safe among the floating fragments of the wreck. But scarcely had the cry been uttered when the rope snapped, and the boat was seen like a dark speck moving away into the mass of white foam. By this time the moon gave a dim flickering light. Though the last hope of deliverance thus seemed gone, not a word was uttered by any one of the passengers, who had become so exhausted that their only desire was for a speedy end. To their surprise, however, the dark speck in the foam, which had disappeared, began to approach, and a human voice was heard from it calling for a rope. It turned out that a wretched sailor, who had seemed to be the worst man on board, confessed that ho had resolved, if any one were to be saved he would. Amid the uproar and darkness he had concealed himself lengthways in the bottom of the boat. When 
it approached the dark line of rock he saw it might be dashed in pieces, and so he seized an oar and held it up against the rock, thus turning the boat round into a small cove. There the next wave threatened to dash him to pieces, so with the energy of despair he grasped a second oar, and succeeded in rowing back to the wreck.

The long-boat could not contain above a third part of those on board; the question therefore was, who should go first. $\mathrm{Had}$ it been at the outset there might have been a rush for the boat, but by this time all tumultuous feelings were assuaged. The prevalent feeling was, that all the lady passengers should if possible get on board. Then a very striking scene occurred: some of these were married, some unmarried. The unmarried ones went to the married men, saying, "You go with your wives,-you are two, we are only one,"-because the wives had said that they would not leave without their husbands. Eventually all the ladies and married men got on board. Manned by a few strong sailors, with the gig leading the way, the long-boat at length reached the shallow sandy beach. The wind after midnight had begun considerably to abate, and all were landed.

Soon after the last boat arrived daylight began to appear. Before this there was no means of knowing whether the place was inhabited; but sounds in endless variety were heard, amongst which all agreed that they could distinguish the braying of asses. It was found that the shipwrecked party had reached an island, of which the only tenants were myriads of penguins who had given forth these discordant noises. The penguin is a bird in size intermediate between a duck and a goose, with short flappers which assist it in swimming and in running quickly along the shore. Soon also it was found that, since at that season the 
penguins laid their eggs in holes burrowed in the sandy surface of the island, there were two Dutchmen on the spot sent from Cape Town to collect the spoil. The passengers bargained with these men for the use of their cooking-pot, and then divided themselves into companies-one, to collect eggs; another, to gather withered grass and sea-weed for the fire; and a third, to remain by the pot and constantly boil the eggs as their only food.

Soon after this a sailor, walking along the beach, noticed an object cast ashore. Going up to it, he found it was a quarto copy of Bagster's Bible and a Scotch Psalm-book, somewhat shattered but with Mr. Duff's name written distinctly on both. The precious volumes had not been used on the voyage out. Wrapped in chamois leather they had been put with other books in a box, which must have been broken to pieces. The sailor who found the volumes high and dry on the beach had been the most attentive at the service which the missionary had held with the crew every Sabbath. Taking Bible and Psalter to the hovel where the passengers sought shelter, with a glowing face he presented them to their owner. All were deeply affected by what they regarded as a message from God. Led by Mr. Duff they kneeled down, and there he spread out the precious books on the white bleached sand. What a meaning to each had the travellers' Psalm, the 107 th which he read, as to all exiles, captives and stormtossed wanderers since the days when its first singers were gathered from all lands to rebuild Jerusalem! What fervent prayer and thanksgiving followed its words, as the band of shipwrecked but delivered men and women lifted their wearied faces to the heavens :

"Whoso is wise and will observe these things,

Even they shall understand the lovingkindness of the Lord." 
For the missionary himself the apparent miracle had a very special meaning, which influenced his afterlife. His letters, so far as we have given extracts from them, have shown that when in all the flush of his college successes he anew devoted himself to God, for what was then dreaded as a missionary career, he counted learning as nothing in comparison of winning 'Christ for himself and for others. As to some of the greatest of the Fathers on their turning from Paganism, Homer, Virgil and Horace had been dear companions, whose lines lingered on the tongue and rang in the ear when their books were not in the hauds, so was it to Alexander Duff. He loved these less only because he cared for the old and never to be dethroned queen of the sciences more. He had but half parted with their companionship, and he could never lose the culture they gave him-the sympathy with all literature by which he was marked till his last days when he read to his grand-children the "Paradise Lost," which classical associations made more dear to him. So when going forth to found a college, a Christian Institute, like Bishop Berkeley at the Bermudas, he had taken with him a library of more than eight hundred volumes, representing "every department of knowledge." All were swallowed up in the shipwreck save forty. And of these forty the only books not reduced nearly to pulp were the Bible, in the best edition of those days, solemnly presented to him by friends in St. Andrews on his ordination; and the Psalter with which Moses and David, Asaph and the other authors of the five books of the original Hebrew lays, have ever since fed the Church of God and comforted sinning, penitent humanity. With the books had gone all his journals, notes, memoranda and essays, dear to an honest student as his own flesh. The instinct which had led all the passengers, even the 
least devout of the twenty-two, to recognise in the preservation of the Bible and Psalter a message from God, became in his case a conviction that henceforth human learning must be to him a means only, not in itself an end. That the word of God abideth for ever, was afresh written upon his soul. The man to whom purely secular scholars in the next generation bore this testimony as the highest they could give, that he was afraid of no truth but sanctified all truth, did not cease, even then, his allegiance to learning in every form when of his books and journals he wrote to Dr. Inglis: * "They are gone, and, blessed be God, I can say, gone without a murmur. So perish all earthly things : the treasure that is laid up in heaven alone is unassailable. God has been to me a God full of mercy, and not the least of His mercies do I find in cheerful resignation."

The land proved to be Dassen Island, in the Atlantic, fo:ty miles N.N.W. of Cape Town and ten miles from the mainland of Africa. From afar they saw the white mist which forms the 'table-cloth' of Table Mountain. The shipwrecked people planned to cross the strait and find their way on foot to the town, but the Dutchmen's skiff was too small to do the work of ferrying in less than a month. So the Irish surgeon of the ship set out alone, and in four days a brig of war rescued them, sent by the humane Governor, Sir Lowrie Cole, although it was just weighing anchor for other duty at Port Elizabeth. The surgeon had sought an immediate interview with his Excellency, who had just finished his despatches. The gallant soldier, who had been one of Wellington's generals in the Peninsular

- Extract of a Letter respecting the Wreck of the "Lady Holland," East Indiaman, from the Rov. Alexander Duff. Edin. burgh, 1830. 
war, declared, "humanity has the first claim." The weather-beaten party landed in the midst of the British and Dutch inhabitants, who crowded to express their sympathy.

Mr. and Mrs. Duff were received by the Rev. Dr. Adamson, son of that minister at Cupar Fife who had been colleague of Dr. Campbell, father of the Lord Chancellor. For weeks the passengers were detained. The next East Indiaman was so full that three of them paid a hundred guineas each to be allowed to swing their cots in the steerage. Furlough rules make no allowance for even shipwreck, and high salaries draw belated officials. Mr. and Mrs. Duff could get a passage in the last ship of the season, the Moira, and that only on payment of 3,000 rupees! This sum was equal to $£ 26210 \mathrm{~s}$. in gold, such was the rate of exchange then as now. From Cape Town he thus addressed Dr. Chalmers :-

"Cape Town, March 5th, 1830.

"My Dear Doctor,-I know your time is precious and I shall not detain you, as my tale may be briefly told: On Saturday night, February 13th, the Lady Holland was wrecked off Dassen Island, forty miles north from Cape Town, but not a life was lost, not even a personal injury sustained by any one of the passengers or crew. This is the fact : for a detail of the fact and its consequences I refer you to a communication of this date, addressed to Dr. Inglis as the official organ of the Assembly's committee. You will there have an account of the nature of our danger and deliverance, our severe loss and future prospects. And the object of my writing to you separately, isthat a circumstance so calamitous in its aspect may not be permitted to cool zeal or damp exertion, but may be improved, to kindle a new flame throughout 
the Church and cause it to burn inextinguishably. As remarked in the communication referred to, " though part of the first-fruits of the Church of Scotland in the great cause of Christian philanthropy has perished in the total wreck of the Lady Holland, the cause of Christ has not perished. The former, like the leaves of autumn, may be tossed about by every tempest; the latter, more stable than nature, ever reviving with the bloom of youth, will flourish when nature herself is no more.

" The cause of Christ is a heavenly and divine thing, and shrinks from the touch of earth. Often has its high origin been gloriously vindicated. Often has it cast a mockery on the mightiest efforts of human power. Often has it gathered strength amid weakness, become rich amid losses, rejoiced amid dangers, and triumphed amid the fires and tortures of hell-enkindled men. And shall the Church of Scotland dishonour such a cause, by exhibiting any symptoms of coldness or despondency in consequence of the recent catastrophe! God forbid. Let her rather arouse herself into new energy; let her shake off every earthly alliance with the cause of Christ, as a retarding, polluting alliance; let her confide less in her own resources and more in the arm of Him who saith, 'Not by power, nor by might, but by My Spirit.' From her faithful appeals let the flame of devotedness circulate through every parish, and prayers ascend to ' the Lord of the harvest,' from every family; and then may we expect her fountains to overflow, for the watering and fertilizing of many a dry and parched heathen land.

"This is the improvement suggested; and of all men living you, my dear Doctor, are, with God's blessing, the individual most capable of making it. Let the committee be awakened, and, from the awaken. 
ing appeals of the committee, let the Church be aroused. Who, that has heard it, can ever forget your own vivid description and eloquent improvement of the magnificent preparation and total failure of the first great missionary enterprise? From it ours stands at an immeasurable distance; but the principle is the same. I fear that much of calculating worldliness is apt to enter into the schemes and preparations of the Assembly. And now Heaven frowns in mercy, and buries a portion of its fruits in the depths of ocean, to excite, if possible, to the cherishing of a holier spirit, and a more prayerful waiting on the Lord for the outpouring of $\mathrm{His}$ grace.

"Mrs. Duff desires her kindest remembrance to you, and with kindest regards to Mrs. Chalmers and family, I remain, my dear Doctor, yours most sincerely,

"Alexander Duff."

"Sunday sail, never fail," was the chant to which the sailors lifted the anchor for Calcutta. But the day proved to be no better omen than the derelict timber-ship which had crossed the bows of the Lady. Holland in the English Channel. Contrary winds drove the Moira to fifty degrees of south latitude, and then for weeks she was beaten out of her course by westerly gales, culminating off Mauritius in a hurricane which threatened the foundering of the ship. Although the year 1830 was well advanced, and Lord William Bentinck had not been satisfied with the first attempt to send a steamer from Bombay to Suez, all the rewards offered had failed to discover the course and the tacking which have since reduced the Cape voyage from an uncertainty that might spread beyond half the year, to an average of a hundred days. Not till near the end of May did the Moira sight the hardy little pilot brig which, far out in the Bay of Bengal 
but still in the muddy waters of the united Ganges and Brahmapootra rivers, is the advanced post of British India proper.

The hot sun was blazing with intensest power as the belated East Indiaman was carefully navigated into the estuary of the Hooghly, the most westerly of the so-called mouths of the Ganges. Hardly had she been moored in the rapid stream off the long, low muddy flat of Saugar Island, when the south-west monsoon was upon her in all that splendid fury which the Hindoo epics describe with almost Homeric realism. The clouds hid the sun, and gave birth to a storm which soon changed into the dreaded cyclone. It seemed a portentous welcome at the very threshold of India, after the previous wreck at its then outmost gate. In spite of three anchors thrown out the Moira was dragged, tossed and-as we have twice since seen in similar cases-lifted by the wind and the storm-wave on to the muddy shore of the Saugar, the sagara or Coblentz or confluence of Gunga with the ocean. The river was of unusually yast volume, the low delta land was flooded. Poised on the very edge of Saugar bank, with some ten feet of water on the shore and sixty or seventy on the river-side, and wedged in this position by the force of the hurricane, the Moira worked for herself a bed in the clay. There is no time for calculation when the genius of the cyclone rides the rotary storm so that no living thing can stand upright. But instinct takes the place of thought, and the love of life develops daring which, in calmer hours, were madness. The vessel was soon found to be very slowly heeling over into the deep water. But nothing could be done, for the great wind of heaven was still loose, and the midnight darkness that might be felt was broken only by the flash of the forked lightning. The captain managed 
to secure the ship's papers on his person, and waited for the dawn, which revealed the vessel leaning over at a sharp angle, but still kept from disappearing by the wedge-like compression of the silt of the bank. Often afterwards did Alexander Duff describe the scene on which that May morning broke, and the deliverance.

The appearance of the river from the cuddy portion of the hull was very awful. The wind, in mighty whirling eddies, raised up columns of water which came down like so many cataracts. From the extremely perilous position of the ship it was necessary that all should be put on shore, but that meant deep water. One large tree, however, was espied, and to that the pilot and the natives succeeded in making a hawser fast, by swimming to its branches. Along this a boat was moored to the tree, and there, on somewhat higher ground, the passengers were "landed" up to the waist in water, at the time rolling in billows. The wind drove all, passengers and crew, inland to a village where caste forbade the natives to give them shelter. The island stretches for ten miles in length and five in breadth, and at that time had a population of some ten thousand persons, who lived by the manufacture of salt, and on the offerings of the pilgrims at the annual bathing festival of the wirster solstice, which used to attract a quarter of a million of devotees from all parts of India. Denied access to the few huts that were not flooded, the shipwrecked party took possession of the village temple. Whether it was that of the sage Kapilmoonnee, whose curse had destroyed the eponymous Sagar, king of Oudh, with its great banyan tree in front, or the tiger-haunted pagoda which forms the centre of the fair, we know not. But it was thus that the first missionary of the Church of Scotland was, with his wife and fellows, literally thrown on the mud-formed strand of Bengal, where 
the last land of the holy goddess, Gunga, receives her cmbrace, and many a mother was then wont to commit her living child to the pitiless waters.

When the tidings reached the capital, a hundred miles up the Hooghly, numerous small boats of the covered "dinghy" class began to appear. In one of these Mr. and Mrs. Duff arrived at the City of Palaces, drenched with mud, and terribly exhausted after twenty-four hours in the temple following such a day and night of storm. Young Durand, too, found his way to the city, to the palace of the Bishop, where the tall lieutenant for some days excited amusement by appearing in the epicene dress of his kind host. The Duffs were hospitably entertained by Dr. Brown, the junior Scottish chaplain. In due time three steamers dragged the Moira off Saugar shore, sorely shattered, but thus the baggage was saved. It was on the 27th May, 1830, that they reached the scene of the next third of a century's triumphs, having left Edinburgh on the 19th September, 1829, more than eight months before.

The first to visit Mr. Duff the evening on which he landed were his old St. Andrews companion, the Rev. J. Adam, and his afterwards life-long friend and greatly beloved brother, the Rev. A. F. Lacroix, both of the London Missionary Society. Next day came the venerable Archdeacon Corrie, fruit of Simeon's work; also Dr. Bryce, the senior chaplain; General Beatson, and other Christian strangers, who, with the more than freemasonry that has not yet died out of Anglo-India, desired to welcome Duff to Bengal. His own letters of introduction, preserved on his person in the two shipwrecks, he duly presented. With his wife he lost no time in calling at Government House on Lady William Bentinck, who received them not merely with courtesy but with genial Christian 
sympathy. The Governor-General himself did not need the letter from a personal friend at home, to give the young missionary a warm reception. His Excellency sent for him, spoke encouragingly to him, and at a private dinner fully entered into his plans. Was Lord William not the greatest of the Bentincks, the best of all the Governor-Generals?

Alexander Duff was little more than twenty-four years of age when, a tall and handsome man, with flashing eye, quivering voice, and restless gesticulation, he first told the ruler of India what he had given his life to do for its people. Heir of Knox and Chalmers, he had to begin in the heart of Hindooism what they had carried out in the mediævalism of Rome and the moderatism of the Kirk of the eighteenth century. He had also to make it a missionary Kirk. His work was to be twofold-in East and West.

Need we wonder that, when the Calcutta newspapers told the story of the repeated shipwrecks, the very natives remarked - " Surely this man is a favourite of the gods, who must have some notable work for him to do in India?" 


\section{CHAPTER IV.}

\section{0.}

\section{OALCUTTA AS IT WAS.}

Duff disobeys the only Order of his Church.-Calcutta a fourth of London.-Bengal.-Job Charnock selects Kalkatta.-The First European Settlers.-Growth of the City.-Natives begiuning to learn English.-Founders of the great Bengalee Families.-The leading Natives on Duff's Arrival.-The washerman who first tunght English.-Adventure Schools.-Matrimonial Value of Penmanship then and of the M.A. Degree now.-The Oriental Colleges and Orientalists.-Despatches Written by James Mill.Duff's Account of the Origin of the First English College in India.-Tentative Effurts of the Early Missionaries.-The Work of Destruction Begun, who shall Construct?

Having secured full power to carry out his own plans unfettered by conditions in Scotland or on the spot, and having failed to obtain from his Church any instructions for his guidance save one, Mr. Duff's first duty was to refuse to give effect to that one. He had been forbidden to open his mission in Calcutta. Why, it is difficult to understand, in the absence of all reasons assigned for such a prohibition. So the agents of the Scottish Missionary Society before Dr. Wilson had neglected Bombay city, while shut out from the Maratha capital of Poona, and had wasted years in the obscure villages of the Konkan. The example of the Apostles, beginning at Jerusalem, might have sufficed. The first of all Protestant missions and colleges in Bengal had, indeed, been established outside of the capital, but that was because the East India Company's early intolerance had driven Carey 
and Marshman to the protection of the little Danish Government at Serampore. Bishop Middleton had followed, spontaneously, the unfortunate precedent, by building his Gothic pile so far down the right bank of the Hooghly that his college has proved useless for its great object ever since. This only had been determined on by Dr. Inglis and Mr. Duff, that the first missionary was to open a school or college, just because that line of proselytising work had been neglected by the few other missionaries then in Calcutta. When Duff had seen these at work, in the city and all round it to Carey at Serampore, and twenty-five miles up the river to Chinsurah and the old factory of Hooghly, he resolved to begin his career by disobeying the one order he had received. It was the resolve of genius, the beginning of an ever-growing success, without which failure, comparatively, was inevitable. The young Scot had vowed to kill Hindooism, and this he could best do by striking at its brain. Benares, Pooree, Bombay more lately, might have been its heart; but Calcutta was its brain. Let others pursue their own methods in their own places, he would plant his foot down here, among the then half-million eager, fermenting Bengalees, feeling after God if haply they might find Him with Western help, and about to be used by the English Government as instruments for carrying its civilization all over Eastern, Central and North-western India.

Calcutta, the metropolis of the British Empire in the southern half of Asia, now covers an area of thirty-one square miles, and has a fixed population of 900,000 , exclusive of the hundreds of thousands who daily visit the port, the markets, the offices, the warehouses, the domestic homes and the schools for trade, service and education. That is, the greatest city of the English in the East is just one fourth the size, in area and inhabitants, of London itself within the 
jurisdiction of the Metropolitan Board of Works or the district of the School Board. London had the same population at the beginning of this century as Calcutta now has. To what point Calcutta will reach in the next century, under the same wise and peaceful administration which has made it what it is, he may conjecture who best realizes its unparalleled position. It is at once the centre of the most densely packed and fast-breeding rural population in the world, and of a network of rivers, canals and railways compared with which those that have created Holland are microscopic. It is the focus of our whole political system in Asia.

Itself impregnable by nature and the entrepot of the wealth of Bengal, Calcutta has sent forth triumphant expeditions to Burma, to Java, to Canton and to Peking in the far East. It has been prepared to civilize the Maories of Australasia, as it had previously pushed the edge of the sword that separates evil from good into the heart of the Pathans of the Suleiman range and the Western Himalayas. From Calcutta, Mauritius and even the Cape have been started on a new career. Embassies from the palace of its GovernorGeneral, still known simply as Government House, seventy years ago dictated terms of peace and progress, against the barbarous aggression of Russian and French absolutism, to the Shah of Persia, the Ameer of Cabul, and the Maharaja of the Sikbs, when the Sutlej was our only frontier besides the sea. Were we basely to retire from the responsibilities of empire, and confine our administrative system to the one Lieutenant-Governorship of Bengal, its swarming sixty millions would enable Calcutta to send to the mother country a clear annual surplus of from four to six millions sterling. For it is with the twelve millions of revenue yielded every year by Bengal, that 
Calcutta has spread the British Empire all over Southern Asia.

In the Old World there is no example of the growth of a capital so rapid. In 1596 this mighty metropolis figures on the rent-roll of the Emperor Akbar as Kalkatta, one of three villages in the district of Hooghly which together paid an annual tax of $£ 2,341$. The great temple, still in its suburbs, is that of the black destroying goddess of Kaleeghat. Driven from the factory at Hooghly by the Mussulman officer of Avrungzeb, the East India Company's agent, the notorious Mr. Job Charnock, with his council, sailed down the river in search of another site. Oolabaria, on the same right bank and somewhat below the present Botanical Garden, was tried. But, though the ferry town on the high road to the shrine of Jugganath, in Orissa, that place had the two disadvantages of bad anchorage and exposure to the raids of the Marathas. Not so the high ground immediately to the north of Kalkatta. There the river was deep; its expanse, a mile broad at high water, protected the place from the western devastators; and the surrounding inhabitants were a prosperous brotherhood of weavers for the Company's trade. Under " a large shady tree," somewhere between the present Mint and the most orthodox quarter of Sobha Bazaar, Job Charnock set up the Company's flag and his own zanana. For he had taken to himself the beautiful Suttee or Hindoo widow whom he rescued from cremation only to be himself Hindooized, and on whose tomb he used afterwards to sacrifice a cock, according to that contemporary gossip, Captain Alexander Hamilton. It is significant that the second college which Duff built as the Free Church Institution stands in the great thoroughfare leading down to the oldest burning ghaut, Neemtolla, the 
place of the neem-tree, which name probably embalms the tradition of that "large shady tree." Many a suttee must have taken place within ear-shot of the founder of Calcutta, who used to have his sentences of whipping executed on native offenders "when he was at dinner, so near his dining-room that the groans and cries of the poor delinquent served him for music."

The days of the glorious Revolution had come; the new East India Company got a new and most Christian charter; the old church of St. John was raised with a proud steeple only to be cast down by the next cyclone; and the Fort, of Black Hole memory, was built in Kalkatta village under William the Third's name. The Court of Directors, too, under revolution influences, became Christian once more, and directed their agent at Calcutta to use this missionary form of prayer: "That these Indian nations among whom we dwell, seeing our sober and righteous conversation, may be induced to have a just esteem for our most holy profession of the gospel." Charnock's rough and, towards the natives, revengeful administration ceased five or six years after his first settlement at Kalkatta. Sir John Goldsborough was sent by the older and then superior Government of Madras to reform the little colony, which he began to do by sending the Roman Catholic priests off to Bandel, because they encouraged the civilians to form connections with the half-breed Portuguese under their influence. "In Calcutta all religions are tolerated but the Presbyterians, and they are browbeat," wrote Hamilton. By 1706 there were 1200 English in the infant capital; but such were the excesses of many of them, and such the absence of sanitary arrangements adapted to the climate, that 460 burials were registered in that year. Hamilton blames the site of 
the factory, and especially the neighbouring saltwater lakes or swamps. But time and science have proved that Job Charnock selected a position on which nearly a million of human beings, many of them foreigners from the cold north, live and labour with a rate of mortality little higher than that of London. The water, the drainage, the gas, the conservancy arrangements of the modern Calcutta may compare favourably with those of the other capitals of the world.

By 1752 the population had grown, according to Holwell, to 400,000 , when the irate Governor of Bengal, Sooraj-ood-Dowla, made a swoop upon them from his capital of Moorshedabad. Of the English who did not flee to the ships one hundred and twentythree perished within twenty feet square of the guardroom called, by the soldiers usually confined there, the Black Hole. Instead of the Hindoo Ghaut of Kalee, the city was re-named the Muhammadan place of Alee, Aleenuggur. But the sack and the burning proved only new sources of wealth, when Clive and Watson had chased the tyrant back to his capital, and had defeated him at Plassey. In 1758 a long procession of a hundred boats, laden with seven hundred chests, and then a second despatch, brought to Calcutta the largest prize that the British people had ever taken, or $£ 1,110,000$ in silver rupees. From much of that, sent as compensation, the citizens, English, Armenian, Portuguese and Bengalee, built the present city of Calcutta and Fort William. The reign of extravagance began; but also that of health, benevolence, education and, gradually, outward respect for religion. There were two thousand Europeans in the new city, many of whom had spent twenty or thirty years in India without once attending public worship. For them a new St. John's arose in the old cemetery. Friends of Cecil, Simeon, and the 
Clapham men were sent out as chaplains, after Clive had purged the services. He himself invited the missionary Kiernander, when Lally had broken up the Lutheran settlement at Cuddalore, to instruct the natives and bury the Europeans in Calcutta, after the only chaplain there had perished in the Black Hole. The Company's ships carried his annual supplies free, and he raised the building which still flourishes, under the Church Missionary Society, as the old mission church, thanks to Charles Grant's foresight. The jungle, termed forest, around the new Fort William was cleared away, and Calcutta obtained that magnificent plain called by the Persian name Maidān, around which are its great public buildings and its Chowringhee palaces. By the close of last century, when the Marquis Wellesley planted down on its edge the fine reproduction of Keddlestone Hall in Derbyshire, designed by the brothers Adams, which is still called Government House, defying the Court of Directors, Calcutta was worthy of the position given it in the days of Warren Hastings as the seat of the central government. By that time it had become the outlet and the inlet for the trade of all Eastern and Northern India up to the Sutlej, so far as the Company's monopolies allowed trade to follow a natural course.

The necessities of intercourse with the natives, diplomatically with the court at Dacca and Moorshedabad and commercially with the capitalists and manufacturers, had early created a class of intermediaries and assistants between the English and the people of the country. Of the former was the Punjabee Omichund, the wealthy intriguer who tried to cheat both Clive and the Muhammadan ruler, whom he had instigated to the destruction of the English, and was defeated by his own weapons. Of 
the latter were nearly all the great Hindoo families which are still the beads of native society. Lord Clive's moonshee was, to his countrymen, more powerful than the great Governor himself. Raja Nobokissen founded a house like the Barings of England. More famous at the time, though now forgotten, was Clive's dewan, Ramchand. In the year of the victory of Plassey each of these men had a salary of $£ 72$ pounds; yet on his death, in 1767, ten years after, the latter left a fortune of a million aud a quarter sterling. Nobokissen spent ninety thousand pounds on his mother's obsequies. The various ghauts, or bathing places, on both banks of the Hooghly, from Calcutta to Serampore, commemorate at once the wealth and the superstition of the men who, in those days, lived on the ignorant foreigners whom they assisted, and on their own less educated countrymen whom they oppressed. Many a Bengalee proverb has come down from the times of Clive, Verelst and Hastings, such as the triplet which Mr. J. C. Marshman used thus to render-

\footnotetext{
"Who does not know Govindram's club, Or the house of Bonmalee Sirkar, Or the beard of Omichund?"
}

Govindram Mitter was the "black zemindar" who for thirty years was the nominal subordinate of the English collector of the taxes of Calcutta on from $£ 36$ to $£ 60$ a year, and whom only the brave Holwell, hero of the Black Hole time, finally deprived of the power to oppress like a Turkish pasha. The cruel exactions of Raja Daby Sing under Warren Hastings have been handed down to everlasting shame by the eloquence of Sheridan.

The adrance merchants known as "Daduny," through whom the Company made its contracts with 
the native weavers for their calicoes and muslins, which Lancashire soon learued to manufacture from Indian cotton for export, were the first to learn as much English as was necessary for their intercourse with the masters they defrauded. A lower class were the panders and agents whom ship captains were forced to use, and who still, as from the seventeenth century, mislead our sailors to their too frequent destruction. These were termed "dobhasias" or twolanguage natives, a word used in the earlier commercial transactions at the Portuguese Calicut and the English Madras. Ram Komul Sen, the author of the first English and Bengalee dictionary, tells in his preface how the first English captain who sailed to the infant Calcutta sent ashore asking for a dhobasia. The Setts, the Bengalee middlemen who helped Job Charnock to buy the Company's piece goods, in ignorance of the word sent a "dhobee" or washerman on board, with propitiatory gifts of plantains and sugar-candy. To that washerman, who made good use of the monopoly of English which be acquired, the native lexicographer ascribes "the honour of having been the first English scholar, if scholar he could be called, amongst the people of Bengal." The mere vocabulary of nouns, adverbs, and interjections, which, for nearly a century, constituted the English of the Bengalees, as it still forms that of the domestic servants of Madras, became improved when Sir Elijah Impey went out to establish the Supreme Court in 1774. Cases like the trial and hanging of Nuncomar for forgery, and the growing business of the Court which included all the citizens of Calcutta in its jurisdiction, while the judges strove to extend their power far into the interior, made the next generation of middle-class Bengalees a little more familiar with English. Interpreters, clerks, copyists, and agents of 
a respectable class were in demand, alike by the Government and the great mercantile houses. For a time Lord Cornwallis pursued the illiberal and, as it proved, impossible policy of employing only Europeans. Hence the greatest native of the time, whom we shall learn to admire hereafter, Raja Rammohun Roy, did not begin to learn English till he was twenty-two, nor did he master it till he was thirty.

He stood at the head of the leading Hindoo families of Calcutta at the time of Duff's appearance there. After winning the gratitude of the Government as "dewan" or principal native assistant to the Collector of Rungpore, he had settled in the city in 1814. Others worthy of note were Dwarkanath Tagore, of the mercantile firm of Carr, Tagore \& Co., and his cousin, Prosunno Coomar Tagore, great landholder and lawyer. Ram Komul Sen, already alluded to, was "dewan" of the Bank of Bengal. Russomoy Dutt was at that time "banian" or broker to Messrs. Cruttenden, Mackillop \& Co., and afterwards honoured judge of the Small Cause Court. Raja Radhakant Deb was head of the orthodox party. Ram Gopal Ghose was a member of the firm of Messrs. Kelsall, Ghose \& Co. These were the principal English-speaking native gentlemen, the most active in the education of their countrymen, the reformers before that reformation of which the young Scottish missionary became the apostle. We shall see how the Christianity that he brought and applied, in a form adapted to the wants of the time, tested them and sifted their families, and still tries their descendants as a divine touchstone.

How did these men and the other respectable Bengalee families get their English, such as it was, before the educational as well as spiritual revolution begun by Duff? First, a keen self-interest drove them to find it at the hands of Eurasians, Armenians, and 
English adrenturers. Then Government, which had ignored and even opposed the English education of the natires, was forced by Parliament to patronise it. Then a very few of the missionaries at that time in Bengal lent their aid. But all proceeded on the same mechanical, utilitarian, and routine system which marked English schools till the days of Lancaster and Bell.

Sherborne, a Eurasian, kept a school in the Jorasanko quarter, where Dwarkanath Tagore learned the English alphabet. Martin Bowl, in Amratolla, taught the founder of the wealthy Seal family. Aratoon Petroos was another who kept a school of fifty or sixty Bengalee lads. The best of the pupils became teachers in their turn like the blind Nittyanund Sen in Colootolla, and the lame Udytchurn Sen, who was the tutor of the millionnaire Mulliks. Their textbooks were such pitiful productions as those of Dytche and Enfield, Cooke's letters and Greenwood's grammar. To write a good hand was far more important than to understand what was read, for to be a copyist or book-keeper was the destiny of the majority. One of the Mullik family, when in 1869 reviewing that period of dim twilight, stated in his own English, " that the betrothment of a maid to a youth fit to wear the laurel of Hymen, was chiefly influenced by the capability of the latter in point of his English penmanship, a specimen of which was invariably called for by the parent of the girl." Now the possession of the degree of Master of Arts is the test, a fact that gauges the whole intellectual and social progress which Duff had come to set in motion for far higher religious ends. As the vernaculars of the country were neglected by the British Government for the Persian of its Mulammadan predecessor, so English had to give way to a vicious orientalism. In 1780 Warren Hastings 
had founded the Madrissa or Muhammadan college in Ualcutta, to conciliate the Moulvies by teaching the whole range of the religion of Islam, and preparing their sons as officials of the law courts. In 1791 Jonathan Duncan, of philanthropic memory, did the same for the Hindoos, by establishing the Benares Sanscrit College avoredly to cultivate their "laws, literature and religion." From Plassey to the charter of 1813 was the most evil time of the East India Company's intolerance of light in every form, so much did it dread the overturning of a political fabric which had sprung up in spite of it. But then the Court of Directors was compelled by Parliament, expressing weakly the voice of the Christian public, to write the despatch of the 6th September, 1813, which communicated the order that "a sum of not less than one lakh of rupees $(£ 10,000)$ in each year shall be set apart and applied to the revival and improvement of literature, and the encouragement of the learned natives of India, and for the introduction and pro. motion of a knowledge of the sciences among the in. habitants of the British territories of India." Weakly, we say, for Charles Grant had, in 1792, sketched in detail, and had continued all these years to press on the court and in Parliament, a scheme of tolerant English and vernacular education, of such far-sighted ability and benevolence that all subsequent progress to the present hour is only a commentary upon his suggestions.*

In spite of the charter of 1813 , that order was not, in its spirit and intention, carried out till Duff landed

- Observations on the State of Society among the Asiatic Subjects of Great Britain, particularly with respect to Morals, and on the Means of Improving it. Written chiefly in the year 1792. Ordered by the House of Commons to be printed, 15th Jane, 1813. 
in Calcutta. First, Colebrooke-the greatest orientalist who has yet lived-when a member of Lord Minto's Council, and then Dr. H. H. Wilson-who, in England, comes only second to him-directed the Parliamentary instructions to t'se establishment of another Sanscrit college, this time in Calcutta. The directors' despatch of 3rd June, 1814, was all in favour of such orientalism, but, though ignoring English, it deserves the credit of having urged the establishment of a system of vernacular schools, on Bell's principles, from a cess on the land. Had that been attended to as each province was added to the empire or settled in its land revenue and tenures, the whole work of national education for which Duff laboured side by side with his English system, as we shall see, might have been done. Instead of either, the public money was so misapplied as to call forth a despatch on the 18th February, 1824, in which James Mill, in the name of the directors, reviewed the fruitless and wasteful past, using this language :-

"The great end should not have been to teach Hindoo learning, but useful learning. No doubt in teaching useful learning to the Hindoos or Muhammadans, Hindoo media or Muhammadan media, so far as they were found the most effectual, would have been proper to be employed, and Hindoo and Muhammadan prejudices would have needed to be consulted, while everything which was useful in Hindoo or Muhammadan literature it would have been proper to retain; nor would there have been any insuperable difficulty in introducing, under these reservations, a system of instruction from which great advantage might have been derived. In professing, on the other hand, to establish seminaries for the purpose of teaching mere Hindoo or mere Mubammadan literature, you bound yourselves to teach a great deal of what was frivolous, not a little of what was purely mischievous, and a small remainder indeed in which utility was in any way concerned. In the new college which is to be instituted, and which we 
think you have acted judiciously in placing at Calcutta instend of Nuddea and Tirhoot as originally sanctioned, it will be much farther in your power, because not fettered by any preceding practice, to consult the principle of utility in the course of study which you may prescribe."

Three years later, on the 5th September, 1827, the directors took a stronger position, when pointing out that the course of education must not merely " produce a higher degree of intellectual fitness, but that it will contribute to raise the moral character of those who partake of its advantages." The writer, characteristically, could not find "the best security against degrading vices" elsewhere than in "that rational self-esteem " of which his greater son's autobiography gives us such sad glimpses. But that despatch had hardly been discussed and angrily answered by the orientalists around the Governor-General, when Duff gave himself to the life task of supplying the only motive power which would secure "the last and highest object of education" to the natives of India.

Fortunately we have his own account of the establishment of the first English college in India, the Vidyalaya, or Anglo-Indian, or Hindoo College, as given in his evidence before the select committee of the House of Commons previous to the Company's last charter of 1853. The immediate precursor of that movement was the minute of 2 nd October, 1815, in which Lord Hastings, declaring his solicitude for the moral and intellectual condition of the natives, projected a system of public instruction, and thereafter visited Serampore to inspect its schools and encourage its missionaries. The David Hare mentioned was the son of a watchmaker in London, who and whose brothers made a modest fortune in India.

"The system of English education commenced in the follow- 
ing very simple way in Bengal. There were two persons who had to do with it,- one was Mr. David Hare, and the other was a native, Rammohun Roy. In the year 1815 they were in consultation one evening with a few friends as to what should be done with a view to the elevation of the native mind and character. Rammohun Roy's proposition was that they should establish an assembly or convocation, in which what are called the higher or purer dogmas of Vedantism or ancient Hindooism might be taught; in short the Pantheism of the Vedas and their Upanishads, but what Rammohun Roy delighted to call by the more genial title of Monotheism. Mr. David Hare was a watchmaker in Calcntta, an ordinary illiterate man himself; but being a man of great energy and strong practical sense, he said the plan should be to institute an Knglish school or college for the instruction of native youths. Accordingly he soon drew up and issued a circular on the subject, which gradually attracted the attention of the leading Europeans, and, among others, of the Chief Justice Sir Hyle East. Being led to consider the proposed measure, he entcred heartily into it, and got a meeting of European gentlemen assembled in May, 1810. He invited also some of the influential natives to attend. Then it was unanimously agreed that they should commence an institution for the teaching of English to the children of the higher classes, to be designated 'The Hindoo College of Calcutta.' A large joint committee of Europeans and natives was appointed to carry the design into effect. In the beginning of 1817 the college, or rather school, was opened, and it was the very first English seminary in Bengal, or even in India, as far as I know. In the joint committee there was a preponderance of natives, and partly from their inexperience and inaptitude, and partly from their absurd prejudices and jealousies, it was not very well managed nor very successful. Indeed, had it not been for the untiring perseverance of Mr. Hare, it would have soon come to an end. The number of pupils enrolled at its first opening was but small-not exceeding twenty-and even all along, for the subsequent five or six years, the number did not rise above sixty or seventy. Then it was, when they were well-nigh in a state of total wreck, and most of the Europeans had retired from the management in disgust, that $\mathrm{Mr}$. Hare and a few others resolved to apply to the Government for belp as the only 
means of saving the siuking institution from irretrievable ruin. 'I'he Government, when thus appealed to, did come forward and proffer its aid upon certain reasonable terms and conditions; and it was in this way that the British Government was first brought into an active participation in the cause of English education.

"The Government then came forward and said in substance, - If you will allow us to appoint a duly qualified visitor, so as to give us some control over the course of instruction, we will help you with a considerable pecuniary grant.' But, however equitable the proposal that they, as large subscribers to the funds, should have an influctial voice in the management, such was the blindfold bigotry of the larger moiety of the native committee, that the interposition of the Government, even in the mild form proposed, was at first very stoutly resisted. At length the sober sense of the smaller moiety prevailed. The first visitor happened to be Mr. Horace Hayman Wilson, the famous Sanscrit scholar. It was not, perhaps, an appointment altogether congenial to his other pursuits, he being thoroughly wrapped up in Sanscrit and Sanscrit lore of every sort. But still, as his influence with the natives was deservedly great, he was appointed to the office; and, as an honourable man, he rigorously resolved to do his duty. He very soon threw new life into the system, and got it very much improved; the number of pupils soon also greatly increased, so that altogether there was a great deal of zeal manifested, and a considerable degree of success attained. At the same time, so far as the Government were concerned, their views at the outset, with regard to the best mode of communicating European literature and science, were somewhat peculiar and contracted; in other words, their views seemed to be that whatever of European literature and science might be conveyed to the native mind should be conveyed chiefly through native media, that is to say, the learned languages of Indiafor the Muhammadans, Arabic and Persian; and for the Hindoos, Sanscrit. 'I'his was the predominant spirit and intent of the British Government."

The college, which had upwards of a hundred students and an endorment of $£ 15,000$ on Duff's arrival, lost all its capital in the commercial collapse 
which occurred soon after. Then, too, perished the Calcutta School Society, established about the same time and on the same principles intolerant of Christianity. Its committee had, in 1823, opened an English school as a feeder to the college, in which it maintained thirty free students out of one hundred and twenty in attendance in 1829. The object was the then far-sighted one of encouraging the purely vernacular schools, in which the public subscriptions were more beneficially used, to train their pupils well in Bengalee before drafting them into English classes. But the fifth report of that societ5, and the official investigations of Mr. Adam soon after, show that there were not more than five thousand native children at school in the whole city of Calcutta when Duff lande'd. Not more than five hundred of these learned Euglish, and that after the straitest sect of secularists of the Tom Paine stamp. Such was the educational destitution of Calcutta, low and high, seventeen years after the Clapham philanthropists had, through Parliament, forced the Court of Directors to promise to educate the natives.

Outside of Calcutta the few missionaries had made somewhat fitful attempts to use English as the best medium for the conveyance of truth. A Hindoo who was " almost a Christian," Jeynarain Ghosal, in 1814 left 20,000 rupees to found that college in Benares which the Church Missionary Society still conducts so well. In the same year, at Chinsurah, the London Mișsionary Society's agent, Mr. May, opened a high school, which received the first grant-in-aid. Helped by Rammohun Roy and Dwarkanath Tagore, Dr. Marshman established many native schools in 1816 ; but it was in 1818 that the great college of the Serampore missionaries was projected to do on the Christian side what the Calcutta Hindoos were attempting on the purely recular. Unhappily, that was not in Calcutta. There 
suttee, infanticide, and the choking of the dying with Ganges mud were as common as in the time of its apostate founder, Job Charnock. Mr. G. Pearce, who landed there three years before Duff, as a missionary of the Baptist society, was even then required to report himself to the police and to make oath that he would behave himself peaceably. Sunday was blotted out of the calendar. Caste and idolatry revelled under the protection of the Company. Human sacrifices and Thug murder by strangling were common. Only four societies, represented by a dozen foreign missionaries, were at work in Calcutta and all Bengal: - the Baptist, the London, the Church, and the Orissa General Baptist. In 1827 there were only nine Baptist and half a dozen Anglican converts in all Calcutta, and of these but a portion were Hindoos, and one had been a Muhammadan. This was the fruit of ten years' labour.

Thus far the work of destruction had begun, and Hindoo hands had been the first to try to pull down their Dagon of falsehood, while Government officials had been active, more or less unconsciously, in propping it up. The Bengalees, beginning to leave even the glimmering and reflected light of natural religion as embodied in the varied concrete of their own system, were groping in the still darker region where all was doubt, where the old was gone and nothing bad taken its place. Who was to arrest the demoralization? Who could so guide the fermenting process as to work into the mass the leaven which is slowly leavening the whole lump? Who should begin the work of construction side by side with that of a disintegration such as even the nihilists of the Hindoo College had not dared to dream of? 


\section{CHAPTER V.}

$1830-1831$.

\section{THE MINE PREPARED.}

Preliminary Researches.-Duff's first Interview with Carey.-They Agree as to the best System of Aggression on Hindooism.-That System confirmed by Experience. - Preparing the Mine and Setting the Train.-The Bible the Base and Crown of the System. - Why Previous Attempts Failed.-Buchanan's Christian Institution in the East. - Serampore College.-Bishop's College and Dr. Mill's Sanscrit Christiad.-All Providential Advantages centred in Duff.-His Bengalee Ally, the Raja Rammohnn Roy, the Erasmas of Hindooism.-The Brumbo Sobha and Dharma Sobha.-Duff's Treatment of Rammobun different from that by Dr. Marshman.-The Theist finds for the Christian a School and five Papils. - The first Day.-The Lord's Prayer and the Gospels in Bengalee.-Opposition of the other Missionaries.-Duff teaching the English Alphabet. - Contemporaneous teaching of Bengalee and English. - Removes to College Square.-First Public Examination of the School converts all Opporents.Branch Institation at Takee.-A new Educational Era in India.Rev. W. S. Markay joins Dnff.-Letter introdncing Rammohun Roy to Dr. Chalmers.-Story of an English Adventarer.-Duff the first to teach Political Economy in India.-The Home Cummittee remonstrate, confounding it with Politics.

Wiтн the exhaustless energy which marked his whole life, Alexander Duff spent the hottest and wettest period of the Bengal year, the six weeks from the end of May to the middle of July, in preliminary inquiries. From early morning till latest eve he visited every missionary and mission station in and around Calcutta, from the southern villages on the skirts of the malarious Soonderbun forests to the older settlements of the Dutch at Chinsurah and the Danes at 
Serampore. There was not a school which he did not inspect; not one of those thatched bamboo and wickerwork chapels, in which apostolic men like Lacroix preached night and morning in Bengalee to the passersby in the crowded thoroughfares of the capital, in which he did not spend hours noting the people and the preaching alike. For he had at once begun that study of the vernacular without which half his knowledge of and sympathy with the natives must have been lost. $\mathrm{He}$ was especially careful to visit in detail representative rural villages, that he might satisfy himself and the committee. From such minute investigations, and from frequent conferences with the more experienced men already in the field, he arrived at two conclusions. These were, that Calcutta itself nust be the scene of his earliest and principal efforts, from which he could best operate on the interior; and that the method of his operations must be different from that of all his predecessors in India.

With one exception the other missionaries discouraged these two conciusions. He had left to the last the aged Carey, then within three years of the close of the brightest of missionary careers up to that time, in order that he might lay his whole case before the man whose apostolic successor he was to be, even as Carey had carried on the continuity from Schwartz and the baptism of the first Protestant convert in 1707. Landing at the college ghaut one sweltering July day, the still ruddy Highlander strode up to the flight of steps that leads to the finest modern building in Asia. Turning to the left, he sought the study of Carey in the house-" built for angels" said one, so simple is it-where the greatest of missionary scholars was still working for India. There he beheld what seemed to be a little yellow old man in a white jacket, who tottered up to the visitor of whom he had already 
often heard, and with outstretched hands solemnly blessed him. A contemporary soon after wrote thus of the childlike saint-

"Thou'rt in our hearts-with tresses thin and grey,

And eye that knew the Book of Life so well, And brow serene, as thou wert wont to stray

Amidst thy flowers, like Adam ere he fell."

The result of the conference was a double blessing, for Carey could speak with the influence at once of a scholar who had created the best college at that time in the country, and of a veruacularist who had preached to the people for half a century. The young Scotsman left his presence with the approval of the one authority whose opinion was best worth having. The meeting, as Duff himself once described it to us, was the beginning of an era in the history of the Church of India which the poet and the painter might well symbolize.

Though for two years the Kirk's committee hankered after a station in the interior, we may at once dismiss the decision to begin first at Calcutta. But the determination, confirmed by all he had seen and heard, to open an English school, in time to be developed into a college different fron any then in existence, and yet only the nucleus of a great spiritual campaign against Hindooism, proved too fruitful in its consequences to be merely stated.

Duff's object was, in the strength of God and the intensity of a faith that burned even more brightly to his dying hour, nothing less than the destruction of a system of beliefs, life, and ancient civilization of the lighest type, based on a great literature expressed in the most elaborate language the world has seen. Up to that time, missionaries in the less Hindooized south of India had been at work for more than a century, and 
had been driven to evangelize the non-Brahnanical tribes. The system remained untouched-nay, remains so to the present day, according to the most scholarly authority, Mr. Burnell.* In the coast settlements of Eastern and Western India, after some twrnty years' labour a few missionaries had detached a few units from the mass by ill-taught vernacular schools generally under heathen masters, and by addressing fluctuating and promiscuous groups in the streets and villages amid the contempt of the learned and the scorn of the respectable classes. Up to that time the converts had not only been few, but their new faith had not been self-propagating. It had died out with them. Of the hundreds of Kiernander's converts during his long work in Calcutta Simeon's chaplains found hardly a trace, so that the biographer of Thomas, $\dagger$ the surgeon who brought Carey to Bengal, doubts their existence. Of the tens brought over by the evangelical clergy of whom Martyn was the type the earlier missionaries found none. The first fact forced on Duff was, that, as against the Brahmanized Hindoos, the prevailing missionary method had failed both in immediate results and in self-developing power. The logical, if also antispiritual conclusion, was undoubtedly that of the Abbé Dubois, who knew no other method-that it was impossible to convert the Hindoos, and needless to try.

Long after that time we have heard the greatest vernacular preacher Bengal has seen, Duff's dear friend, Lacroix, confess that during fifty years he did not know that he had been the means of making one convert from Hindooism. And so recently as this year an equally typical missionary to Islam, the Rev. T. P. Hughes, warns us that there is very little, if any,

* See Academy for Dec. 28th, 1878, page 604.

† The Life of John Thomas, First Baptist Missionary to Bengal, by C. B. Lewis. London, 1873. 
analogy between street preaching in England and in an Indian city. "There the evangelist stands up not as a recognised religious teacher, and the doctrinal terms be uses will either seem strange to the ears of his listeners, or will convey a meaning totally at variance to the one he wishes to impart. But in private interviews the evangelist stands face to face, eye to eye, and heart to heart with the opponent or the inquirer, and can speak as one fallen sinner should speak to another. There is a chord of sympathy in such meetings which is not to be found in the public market-place, and it needs but the touch of love and the power of God's Spirit to awaken its emotions!"* Still stronger and yet more sensitive and true is that chord when it is in the heart of ingenuous and grateful youth, and day after day in the class-room, and night after night in the enthusiasm of the lecture-room or in the hearenly contagion of the secret conversation, the missionary plays upon it with the art of the Master in the synagogue or by the well, and in the oft-frequented places by the sea-shore or on the hill-side.

We have Duff's own statement of his divine strategy when, ten years afterwards, he told the people of Scotland, "In this way we thought not of indiviuauls merely; we looked to the masses. Spurning the notion of a present day's success, and a present year's wonder, we directed our view not merely to the present but to future generations." Admitting the propriety of the direct policy adopted by his fellowlabourers of every sect in other circumstances, he thus "joyfully hailed" them : "While you engage in directly separating as many precious atoms from the mass as the stubborn resistance to ordinary appliances can admit, we shall, with the blessing of God, devote our 
time and sitrength to the preparing of a mine, and the setting of a train which shall one day explorle and tear up the whole from its lowest depths." So John Wilson reasoned on independent grounds, and acted on detailed plans adapted to Western India. So, as against the Brahmanical and Muhammadan systems, all the Protestant-now the only aggressive-missions in Northern India, have gradually come to do. In this sense, education, saturated with the Bible, became the most evangelical and evangelistic agency ever adopted against the ancient Aryan faiths.

When reviewing this period in the last weeks of his life, Duff declared that he was resolutely determined on this one thing: Whatever scheme of instruction he might adopt must involve the necessity of read ing some portion of the Bible daily by every class that could read it, and of expounding it to such as could not, with a view to enlightening the understanding, spiritually impressing the heart and quickening the conscience, while the teacher prayed, at the same time, that the truth might be brought home, by the grace of the Spirit, for the rcal conversion to God of at least some of them. As he read Scripture and the history of the Church, he did not expect that all or the majority of these Bengalee youths would certainly be thus turned, for in nominal Christendom he felt that few have been, or are, so changed under the most favourable circumstances. That "many are called but few chosen," howerer, only quickened his zeal. But he did expect that, if the Bible were thus faithfully taught or preached, some at least would be turned from their idols to serve the living God.

While religion was thus to be in the forefront, his resolution was, from the first, to teach every variety of useful knowledge, first in elementary forms, and, as the pupils adranced, in the higher branches, which might 
ultimately embrace the most advanced and improved studies in history, civil and sacred, sourd literature, logic, mental and moral philosophy after the Baconian method, mathematics in all departments, with natural history, natural philosophy and other sciences. In short, the design of the first of Scottish missionaries was to lay the foundation of a system of education which might ultimately embrace all the branches ordinarily taught in the higher schools and colleges of Christian Europe, but in inseparable combination with the Christian faith and its doctrines, precepts and evidences, with a view to the practical regulation of life and conduct. Religion was thus intended to be, not merely the foundation upon which the superstructure of all useful knowledge was to be reared, but the animating spirit which was to pervade and hallow all, and thus conduce to the highest welfare of man in time and for eternity, as well as to the glory of God. These sentiments he was wont to inculcate in the case of all whom he consulted on the subject at that time. All truth, directed by the two-edged sword of the very word of God, was that which was to pierce to the vitals of Brahman. ism, save the Hindoo people, and make them instruments of truth to the rest of Asia, even more widely than their Buddhist fathers had sought to be.

Wherein did this differ from previous attempts? When, on the 24th June, 1806, Dr. Claudius Buchanan, fruit of the Cambuslang revival, looked back on the horrors of Jugganath worship from an eminence on the pleasant banks of the Chilka Lake, he projected "The Christian Institution in the East," which, " being fostered by Britain, my Christian country, might gradually undermine this baleful idolatry, and put out the memory of it for ever." This was to be a catholic college for translating the Bible into the oriental trongues 
by planting a professor in every province with a language and literature of its own, to report on both and to teach the natives printing. So far as that was not premature, it was being done by the immortal three of Serampore, who refused to impede their own organization by this untried project. Buchanan thereupon turned himself to the creation of the ecclesiastical establishment of a bishop, three archdeacons, and more numerous chaplains. Just as Buchanan had looked to Jews and Armenians as his best missionaries, the men who made the great stride of establishing the Seram. pore College depended on Eurasians or Christians born in the country. Nobly did their agents work, from Ava to Peshawur; but here, too, there was no self-development in the system. The distance of the college from Calcutta shut it out from taking its place as the counteractive of the false philosophy and impure literature taught by the Hindoo College.

When ecclesiastical rivalry stirred up Bishop Middleton to erect of his college, he made the same mistake. He pictured a second grove of Academe, in whichthat is, in the neighbouring arenues of the Botanic Garden-the professors and students would walk, but he left the sweltering class-rooms and debating societies of the Chitpore quarter of Calcutta to atheism and Voltaire. Hence, the only good fruit of the vast expense lavished to this day on Bishop's College has been the Christa Sangita, the Christian epic in Sanscrit of the learned Dr. Mill, its first principal. What one of the early missionaries, who shared the dream, wrote in 1844 is still true : "Sure I am, that if sainted spirits can weep, Bishop Middleton is now weeping is heaven over the idol of his heart."* Men make sys-

- Slietches of Christianity in North India, by the Rev. M. Wilkinson. London, 1844. 
tems, and some men can work in spite of systems doomed to failure. Duff might have in time transformed even Bishop's College, for its two fiundamental objects were to raise native preachers and teachers, and to teach "the elements of useful knowledge and the English language to Mubammadans and Hindoos." But it was more than a fortunate, it was a directly providential combination of circumstances, which culminated in the Scottish evangelization of the Hindoos by education. These were, the sermon of Dr. Inglis in 1818; the call of Alexander Duff in 1828; his wise independence and his wiser disobedience of the only command laid upon him; his unrivalled educational experience as well as spiritual energy; the revolution in belief and opinion begun by the Hindoo College; the official toleration and personal friendship shown by the Governor-General; and, lastly, that to which we now come, the help of the one Hindoo whom English teaching had led to find the living God.

In a pleasant garden house in the leafy suburbs of Calcutta, the Raja Rammohun Roy, then fifty-six years of age, was spending his declining days in earnest meditation on divine truth, broken only by works of practical benevolence among his countrymen, and soon by preparations for that visit to England, where, in 1834, he yielded to the uncongenial climate. "You must at once visit the Raja," said General Beatson, when Mr. Duff presented his letter of introduction, "and I will drive you out on an early evening." Save by Duff himself afterwards, justice has never been done to this Hindoo reformer, this Erasmus of India. He was early misunderstood by the Serampore missionaries in his own country, and he was thus driven into the arms of the Unitarians when he was lionized in Great Britain. Had the truth-seeking Bengalee and the Scottish apostle met when the 
former was yet young, Eastern and Northern India might have been brought to Christ by a Bengalee Luther, greater than their own Chaitunya, instead of their more earnest youth being kept from Him by the Vedic dreams of the Brumho Sobha, and now by the vague ethical naturalism of its successor, the Brumho, Somaj.

At the close of the administration of Warren Hastings, when the bleached bones of the victims of the great famine were beginning to disappear, in 1774, a Brahman landholder and his most orthodox wife had a son born to them on the anoestral estate in the county of Burdwan, some fifty miles from the English capital of Calcutta. Rammohun Roy's fatherhad retired in disgust from the service of the. tyrant, Sooraj-ood-Dowla; his predecessors had been holy ascetics or sacerdotal lords, till the intolerant Aurungzeb forced one of them to take office at court. Their spirit, withdrawing from worldly wealth and distinction, came out in the young Rammohun, who, though trained in all the asceticism of his mother's breviary, the "Ahnika Tattina," renounced idolatry at the age of sixteen, when he wrote but did not publish an attack on "the idolatrous system of the Hindoos." That is, he gave up his fatber's love, his mother's care and his rights of inheritance, and he braved the loss of caste and the persecution of his friends. To this he had been led by too intimate a knowledge of the Bengalee and Sanscrit literature, in his own home, followed by a course of Arabic and Persian at Patna, and by the study of Muhammadanism. From Patna the young and truth-loving theist went to Benares, where he learned that the Brahmanism of his day was a corruption of what seemed to him the monotheism which underlay the nature-worship of the Vedas. Captivated for a time by philosophio 
Buddhism, he visited Tibet, where its practical Lamaic form disgusted him. Recalled by his father, he tried to influence the old man who died in 1803 , and he so succeeded in convincing his mother of the folly of her life-long austerities that she confessed her disbelief in Hindooism before her death. But he had no Divine Saviour to reveal to her. The widow died in the service of the idol Jugganath at Pooree, having declared before she set out on the hideous pilgrimage: "Rammohun, you are right, but I am a weak woman, and am grown too old to give up rites which are a comfort to me."

In a brief autobiography which he wrote in England, he states that he was about twenty when he began to associate with Europeans. "Finding them generally more intelligent, more steady and moderate in their conduct, I gave up my prejudice against them and became inclined in their favour, feeling persuaded that their rule, though a foreign yoke, would lead more speedily and surely to the amelioration of the native inhabitants."

Seeking a livelihood in the service of the English, as his fathers had done in that of the Delli emperors and their Bengal lieutenant-governors, Rammohun Roy became an example of rectitude to the corrupt native officials who made our name detested, and he won the friendship of his British superiors. At fifty he retired to philosophic ease and spiritual meditation, and became the centre of the Calcutta reformers. But he was far ahead of his timid contemporaries, who while approving the better followed the worse. The English language had introduced him to the English Bible, and the necessity of mastering that led him to the original Hebrew and Greek. It was all eclecticism at first, for he admired in the law of the Old and the gospel of the New Testament only the same doctrine of the Adwaita or unity of God, which he had held 
up to his Hindoo and Muhammadan countrymen as the teaching of the Upanishads and the Mesnavi, till they denounced him as nastik or atheist. Of this time he afterwards wrote:- "This roused such a feeling against me, that I was at last deserted by every person except two or three Scotch friends, to whom and the nation to which they belong I always feel grateful."

In the very year, 1814, in which be took up his residence in Calcutta, he opened the Brumho Sobha, in order to teach and to practise the worship of one supreme undivided and eternal God. At first in his own house, and then in the thoroughfare of Chitpore road, he and his pundits expounded in the vernacular the purer teaching of the Vedas, once a week, but on each day of the week in rotation in seven years. They sang hymns to the sound of drum (toblah) and cymbals, (mondeere), guitar (tomburu) and violoncello (bea$l a h)$, such as this: "All is vain without the blessing of God. Remember Him Who can deprive you of wife, children, friends, relatives and wealth. $\mathrm{He}$ is the Supreme, separate from the triune deity (Brumlia, Vishnoo and Siva); to Him belong no titles or distinctions. It is written: 'Blessed is he whose soul dwelleth on Him." Again: "Thine own soul is thine only refuge; seek to cherish it in its proper abode composed of five elements, and guided by six passions. Why dost thou distrust thine own soul? - . God dwelleth even in thine own heart." Christ was shut out from Rammohun Roy by inability or unwillingness to believe His own revelation of the Father and promise of the Spirit. But he set Him, as a practical teacher, far above all others, when, in 1820, he published anonymously that chrestomathy of the synoptic Gospels which he termed, "The Precepts of Jesus the Guide to Peace and Happiness."

His attitude to Brahmanism was still that of Erasmus 
towards Romanism. He believed he could purify the popular religion of its " perversion" while falling back on its early purity. His attacks on idolatry, his declaration of the equality of all living creatures, without distinction of caste, rank, or wealth, under the moral government of God, and of their duty to worship Him according to the most sacred mysteries of the Veds, roused at once the superstitious fear and the aristocratic selfishness of the orthodox families. They met the Brumho Sobha by instituting the Dharma Sobha, to uphold Brahmanism and all its consequences, such as suttee and the denial of civil and religious liberty, of property and marriage to dissidents from idolatry. Thus Hindoo society became divided into opposing camps, while the Hindoo College youths formed a third entrenchment in support of pure atheism and libertinism. These were the three powers at work, unconnected by any agency save the slow and indirect influence of English literature in the hands of vicious teachers, unopposed by Christianity in any form, denounced at a distance, and not once fairly grappled with by any Christian man, from the Bishop to the Baptist missionaries, who had been telegraphed from the Sandheads as "papists" requiring the special attention of the police. The Serampore missionaries, indeed, had taken a part in the conflict, and their quarterly Friend of India had given voice to Christ's teaching on all subjects, human and divine. But they were not on the spot; and, as we shall see, they made the mistake of fighting Rammohun Roy instead of first using him as an ally against the common foe, and then educating him up to the revealed standard. If Rammohun Roy had found Christ, what a revolution there would have been in Bengal! But God works by His own method, and $\mathrm{He}$ sent Alexander Duff to its people and its government, when He had thus prepared the Hindoo to help him. 
Having listened to the young Scotsman's statement of his objects and plans, Rammohun Roy expressed general approval. All true education, the reformer emphatically declared, ought to be religious, since the object was not merely to give information, but to develop and regulate all the powers of the mind, the emotions of the heart, and the workings of the conscience. Though himself not a Christian by profession he had read and studied the Bible, and declared that, as a book of religious and moral instruction it was unequalled. As a believer in God he also felt that everything should be begun by imploring His blessing. He therefore approved of the opening of the proposed school with prayer to God. Then, of his own accord, he added that, having studied the Vedas, the Koran and the Tripitakas of the Buddhists, he nowhere found any prayer so brief and all-comprehensive as that which Christians called the Lord's Prayer. Till, therefore, Mr. Duff had sufficiently mastered the Bengalee and his pupils the English, he recommended him to study and daily use the Lord's Prayer in the Bengalee or Euglish, according to circumstances. But he entirely approved of using the English language, and not the Bengalee, Persian, Arabic or Sanscrit, for conveying sound European knowledge. This led him also to remark that he entirely disapproved of Government having established a new Sanscrit college in Calcutta, against which, at the time of its establishment, he solemnly protested, on the ground that instead of thereby enlightening the native mind according to the intention of the British Parliament, the authorities were confirming it in error and prejudice, and riveting upon it the chains of darkness. He declared of the Indian Governinent that it had acted just as if the English Gevernment, professing to enlighten the natives of the British Isles, instead of setting up a 
school or college for improved literature, science, and philosophy, had established a great seminary for the teaching of all the scholastic, legendary, and other absurdities of the middle ages.

"As a youth," he said to Mr. Duff, "I acquired some knowledge of the English language. Having read about the rise and progress of Christianity in apostolic times, and its corruptions in the succeeding ages, and then of the Christian Reformation which shook off these corruptions and restored it to its primitive purity, I began to think that something similar might have taken place in India, and similar results might follow here from a reformation of the popular idolatry." Till his study of the Gospels, Rammohun Roy had not distinguished between the one universal entity of Pantheism and the personal and supreme God of Theism. When he engaged the Baptist missionary, Mr. Adam, to teach him Greek and Hebrew, he so shook his tutor's faith in the revealed Trinity of Scripture that the Christian relinquished his office, became Editor of the India Gazette, and was generally known in Calcutta as " the second fallen Adam." Then came the controversy with Serampore. Christ had drawn Rammohun so far as to a personal God in the Christian sense. $\mathrm{Had}$ he, at this stage, fallen into the hands of a theologian of comprehensive views and wide sympathies with inquirers struggling to ascertain truth, especially religious truth, in its highest forms, he might have been led to realize, not merely the perfect humanity but the Divinity of Christ as set forth in the Scriptures, and on their divine authority. Though the nature of the incarnation and of the Trinity was incomprehensible to finite and spiritually blinded reason, the facts might have been believed on sufficient authority. It so bappened that one of the Serampore missionaries took him up rather sharply from the title of his 
pamphlet, "The Precepts of Jesus the Guide to Happiness," which seemed to inply that moral precepts alone are sufficient to attain to supreme felicity. This was exposed as a system of mere legalism. Had Rammohun Roy been an orthodox Christian, and, relinquishing orthodoxy, he had come to profess theism and published such a treatise with such a title, it would indubitably have been a sign of his falling from the truth. But it was overlooked that he had been born and brought up an idolater, so that to renounce polytheism in all its forms, and attain to a clear belief in the existence of one God, Creator of all things, was an evidence of his having made considerab.e strides upwards towards the attainment of truth. This provoked him to publish an elaborate reply, which again called forth a rejoinder, and that another from him, so that the controversy became bitter, and he was kept back from the higher doctrines of the Cliristian faith. Such was his attitude towards Christianity when Mr. Duff first made his acquaintance; but he never lost his extreme veneration for the character of Jesus Clirist, and his admiration of the supreme purity and sublimity of His moral teachings. Subsequently Mr. Duff and he had many earnest and solemu discussions on the subject. The testimony of John Foster shows that this remarkable Hindoo died believing in the divinity of the mission of Jesus Christ, including His miracles, but had not attained to an assurance of the deity of His person.

Greatly cheered by the emphatic concurrence of Rammohun Roy, Mr. Duff said the real difficulty now was, where, or how, to get a hall in the native city in which to commence operations; for the natives, owing to caste prejudices, were absolutely averse to letting any of their houses to a European for European purposes. Then, if a suitable place could be got, how 
could souths of the respectable classes be induced to attend, since he was resolved to teach the Bible in every class, and he was told that this would constitute an insuperable objection. For, at that early period, the ignorant Hindoos regarded the Bible with something like loathing and hatred, as the great antagonist of their Shasters; they were also actuated by the"superstitious belief that to take the Bible into their hands, and read any portion of it, would operate upon them like a magical spell, forcing them to become Christians. Rammohun lioy at once offered the small hall of the Brumho Soblia, in tine Clitpore road, for which he had been paying to the five Brahman owners five pounds a month of rental. The few worshippers were about to use a new building which he had himself erected before leaving for England, with the honour of Raja, on a mission from the titular Emperor of Delhi to represent certain complaints against the East India Company. As to pupils, his personal friends were sufficiently free from prejudice to send their sons at his request. Driving at once to the spot, the generous Hindoo reformer secured the hall for the Christian missionary from Scotland at four pounds a month; the liberal $\mathrm{D}$ warkanath Tagrore, who also afterwards died in England, being one of the five proprietors. Pointing to a punkah suspended from the roof, Rammohun said with a smile, "I leave you that as my legacy."

After a few days five bright-esed youths of the higher class, mostly Brahmanical, called upon Mr. Duff, at Dr. Brown's where he still resided, with a note of introduction from Rammohun Roy stating that these five, with the full consent of their friends, were ready to attend him whenever he might open the scbool. One of these, a Koolin named Kliettur Mohun Chatterjee, turned out a first-rate scholar, entered the Government service, and attained to one of the highest 
offices which a native could then hold. He was long greatly respected and trusted for his intelligence and integrity. Having met in the hall with the five on a day appointed, by the aid of an interpreter Mr. Duff explained to them, in a general way, his intentions and plans. They seemed highly delighted, and went away resolved to explain the matter to their friends. In a day or two several new youths appeared along with them, requesting admission. On every successive morning there was a fresh succession of applicants, till classification and weeding out became necessary. When that had been done, a day was fixed for the public opening of the school, at ten a.m., when Rammohun Roy was present to explain difficulties, and especially to remove the prejudice against reading the Bible. The eventful day was the 13th of July, 1830.

Having been meanwhile busy with Bengalee, having obtained from the Bible Society's depository copies of the four Gospels in Bengalee and English, and having borrowed some English primers from the Eurasian teacher of an adventure school, Mr. Duff was ready. Standing up with Rammohun Roy, while all the lads showed the same respect as their own Raja, the Christian missionary prayed the Lord's Prayer slowly in Bengalee. A sight, an hour, ever to be remembered! Then came the more critical act. Himself putting a copy of the Gospels into their hands, the missionary requested some of the older pupils to read. Thare was murmuring among the Brahmans among them, and this found voice in the Bengalee protest of a leader-" This is the Christian Shaster. We are not Christians ; how then can we read it? It may make us Christians, and our friends will drive us out of caste." Now was the time for Rammohun Roy, who explained to his young countrymen 
that they were mistaken. "Christians, like Dr. Horace Hayman Wilson, have studied the Hindoo Shasters, and you know that he has not become a Hindoo. I myself have read all the Koran again and again, and has that made me a Mussulman? Nay, I have studied the whole Bible, and you know I am not a Christian. Why, then, do you fear to read it? Read and judge for yourself. Not compulsion, but enlightened persuasion which you may resist if you choose, constitutes you yourselves judges of the contents of the book." Most of the remonstrants seemed satisfied.

Daily for the next month did the Hindoo reformer visit the school at ten for the Bible lesson, and frequently thereafter till he left for England, when his eldest son continued to encourage the boys by his presence and their teacher by his kindly counsel. But all the Cliristian missionaries kept aloof when they did not expostulate with the young teacher, whose weapon of English seemed to them as unbiblical as his alliance with the author of "The Precepts of Jesus" was unholy. In vain did Duff reiterate to them his leading object, which was, by proper culture, to awaken, develop, stimulate and direct the various powers and susceptibilities of the human mind, and for this end to employ the English language as the most effective instrument; to imbue the whole knowledge thus imparted with the spirit of true religion; and at the same time to devote daily a portion of time in every class to the systematic study of the Bible itself-not in the way of formal scholastic exercise, but of devotional and instructive study, not merely with a view to intellectual illumination but with a view also, by the advocacy of the grace of God's Spirit, to the conversion of the soul to God. It was vain for him thus to show that if what is ordiuarily called secular useful knowledge should be largely communi- 
cated, that would be in inseparable alliance with divine truth. It was vain for him to state that he not only did not disapprove, but on the contrary wholly approved of their modes of operation, as probably the only means which at an early stage could be practised. In the then backward state of things these, he said, were carried on under great disadvantages and consequently comparative inefficiency; still, as progress advanced, the time might come when they could be worked more effectively, therefore his own intention was to master the vernacular language with a view to usefulness in various forms through that medium. It was vain for him to explain that while the English language would thus be used as the channel of conveying all higher and improved knowledge, he was determined that the vernacular should be thoroughly tanght to the pupils at the same time, as a channel of distribution for the masses. The other missionaries constantly harped on this fact, that many of the low natives in Calcutta sought a smattering of English only to carry on dealings with the sailors, whom they allured to low taverns, there to revel in all manner of wickedness, contriving at the same time to rob them of what money they possessed, and often even stripping them of their clothes, and throwing them into the street to be taken up by the police. English had thus corne to be in bad odour with the early missionaries, as regarded these low caste natives on the one hand, and its apparent effect in leading the children of the better class natives into the wildest infidelity.

With regard to the natives who wished to learn English for such purposes, Mr. Duff's reply was that, even on the low ground of the principles of political economy, he would soon by the multiplication of these overstock the market, and make it necessary for those who wished to obtain better positions to remain longer 
at school, so as to gain a higher degree of knowledge, which might not only enlarge the intellect but regulate the morals and manners. With regard to the children of the higher classes, his trust was that the thorough inculcation of God's word, with prayer, would have the effect of preventing them from becoming utter unbelievers or atheists, and in all respects make them better men and members of society, even if they did not outwardly and formally embrace the Christian faith. On the evening before the day of opening the school, one of the missionaries, who had become his dearest friend, came to his house vehemently to expostulate with him at the eleventh hour. When his friend saw that he could make no impression on the far-seeing Scotsman, he rose, and, shaking him by the hand, looked imploringly in his face, saying that he was sorely grieved that his coming to India might, by the course he intended to pursue, prove a curse rather than a blessing. The simple remonstrant exclaimed, as a parting shot, "You will deluge Calcutta with rogues and villains."

The school thus fairly started, let us look at its founder at work. The student who had passed out of St. Andrews University its first scholar, its most brilliant essayist, its most eloquent debater; the preacher whose fervent utterances had thrilled the collest assemblies by addresses which promised a rival to Chalmers himself, and were afterwards hardly exrelled by Edward Irving's; the man who had been the stay and the counsellor of all on board the two wrecked vessels, is doing-what? Destitute of assistants, save an untrained Eurasian lad, and despised by his brother missionaries, he is spending six hours a day in teaching some three hundred Bengalee youths the English alphabet, and many an hour at night in preparing a series of graduated school-books, named 
"Instructors," which held their place in every Chris. tian English school in Bengal for the third of a century. Men, wise in their own narrow sphere and unable to comprehend, because unwilling to study, circumstances so different as those of the educated Hindoos, ask if the power's of a minister of the gospel are to be degraded by such work? Yet without that sowing of seed the great tree would still have to be planted. Without that humility Duff would have been like the average of his fellows, whose inconderate short-sightedness was soon turned into admiration and then imitation. It was the genius of Duff, sanctified by the purest self-sacrifice, that led him to begin thus, as his Master taught, in the spirit of a little child.

His school-books were constructed on a system. The first contained lessons on interesting common subjects, in which the pupils might be drilled not only in reading but in grammatical and other exercises. The second consisted of religious lessons, taken for the most part from the Bible itself,especially the historical portions, and put into forms adapted to the opening intelligence of the youth. These were carefully read, expounded and enforced on the understanding, heart and conscience, as purely religious exercises, without reference to construing which would only desecrate the subject matter.

As to the English alphabet, which most of the pupils had to begin for the first time, Duff devised a plan for teaching a large number simultaneously. He got a board supported by an upright frame, and along the board a series of parallel grooves. He then got the letters of the English alphabet painted on separate slips of wood. Around this upright frame a large class was arranged in a semi-circle. The first letter with which he uniformly began was the letter " 0 ," 
because of the simplicity of its form and sound, and because the sound and the name are the same, as is the case in Sanscrit and Sanscrit-derived vernaculars. When this letter was thoroughly mastered, which was soon done, the next letter which he usually put into one of the groores was " $\mathrm{X}$." $\mathrm{He}$ would then bring the two letters together, and pronouncing them would say, " $\mathrm{O}, \mathrm{X}, O x$. " He then would tell the pupils that this was the name in English for an animal with which they were all well acquainted, and would give them the corresponding word in Bengalee. This always delighted them, as they said they not only knew two letters of the English alphabet, but had already got hold of an English word. So overjoyed they were at this, that when they went out into the street, and met an ox pulling a native cart (which they were sure soon to do), they went along gleefully shouting at the top of their voice, " $\mathrm{Ox}$, Ox." But the new missionary. was not satisfied with giving the Bengalee or the English word. He began to question the boys as to the properties and the uses of the objects, or different parts of the objects, which the word represented. This exercise always delighted them, for it was fitted to draw out what information they already possessed, and to stimulate the powers of observation. In this way the intellect was fairly awakened, and the boys delighted in thinking that they had acquired something like a new power or faculty. In a word, they had become thinking beings. The same process of minute interrogation was carried on in all the classes. The boys, in their exuberance of delight, would be constantly speaking of it to their friends at home, to the pupils of other schools, and to acquaintances whom they might meet in the street. In this way, as well as for other reasons, the school soon acquired an ex- 
tensive popularity among the native community, and the pressure for admission increased far beyond what the little hall could accommodate. In the face of the old mechanical and monotonous style of teaching then universally prevalent, this method was felt to be a real novelty. In the course of time it led others, so far as they could, to imitation, so that ere long the new system was fairly initiated in most of the Calcutta and in many of the Bengal schools.*

We have Duff's own account of the genesis of his educational system, given to the students who had been made by it all they became the third of a century afterwards, when he was bidding them farewell. His method was the same to which John Wilson was led in Bombay. "A passage in the introduction to the celebrated Lectures on Mental Philosophy by the late Dr. Thomas Brown, the successor of the famous Dugald Stewart, relative to Education being, when properly conducted, the grandest practical application of mental science, first drew my attention, theoretically, while yet a student, to the real philosophical basis of a sound and enlightened education. A personal inspection, at a much later period, of the Edinburgh Sessional School, then, in the absence of Normal schools, the most renowned in the kingdom, showed me what the intellectual and interrogatory system of education might and ought to be in practice. With adaptations and modifications specially suited to the peculiar circumstances of India as it then was, this was essentially the system introduced and wrought out, from the very first day on which our school was opened."

- A similar process was going on in Scotland where Dr. Andrew Thomson condescended to the same hnmble but then necessary tusk of primer-writing, alpbabet-teaching and map.illustration, and trained Mr. Thomas Oliphant to make English education what it bas since become in Edinburgh and in Glasgow. 
Increased accommodation was secured, and the next step was taken. The decree went forth that none would be allowed to begin English who could not read with ease their own vernacular. The purely Bengalee department was then created, in a bamboo shed with tiled roof erected in the back court. Under pundits carefully supervised by the missionaries, that has ever since formed an essential part of the organization. But, for the first time in Bengal, the English-learning classes also were required to attend it for an hour daily. This contemporaneous study had two results of vast national importance,-it tended to the enriching of the vernacular language with words, and the then barren literature with pure and often spiritual ideas. This system developed into that study of Sanscrit which, in due time, the University was enabled to insist on in even its undergraduate examinations, with the happiest effects on both the language and the literature. Thus, too, Mr. Duff carried on his own Bengalee studies, the rivalry between teacher and taught, and the marvellous aptitude of the taught, adding to his one over-mastering motive a keen intellectual stimulus. That could not be drudgery which was thus conducted, and was in reality the laying of the foundations of the Church of India broad and deep in the very mind and conscience of each new generation.

Thus the first twelve months passed. The school became famous in the native city; the missionary had come to be loved with that mixture of affection and awe which his lofty enthusiasm and scorn of ineffciency ever excited in the Oriental; and the opposition of his own still ignorant brethren was not abated. For this was no gourd to grow in a night and perish in a night; and till, vulgar success comes commonplace people do not perceive the gifts of others, as Pascal remarks. Duff now resolved that he must live as well 
as work in the very midst of the natives, and be in hourly contact with them in the street as well as in his own house. No European had ever before resided there, nor was any Hindoo prepared to let a house to one who would pollute it by the consumption of beef, and cast an evil spell on the neighbourhood. Many a week passed in fruitless endeavours to find an abode, when a two-storied tenement, uninhabited for twelve years because of the belief that it was haunted, was with much entreaty obtained in College Square. The locality, fronting the Hindoo and Sanscrit Colleges, was so central, that it was long afterwards secured by Mr. Barton for the Cathedral Mission College, and the Medical College and University have been built on the third side of the square. Up to this time he had lived to the south, on the same line of road, in Wellesley Square, fronting the Muhammadan College and close to the site of the future Free Church building. He thus fairly planted himself in the citadel of the enemy, and he was driven from it to another quarter only by the unhealthiness of the house. He subsequently built his first college, still known as the General Assembly's Institution of the Established Church of Scotland, and his own dwelling-place-succeeded, after 1813, by another close by-in Cornwallis Square, to the north.

Despairing of inducing the European community to follow him, in order to test the results of his first year's labour he announced the examination of his pupils in the Freemasons' Hall. To remove the prejudice that his work was low and fanatical, he secured Archdeacon Corrie as president on the occasion. It was an experiment, but Mr. Duff felt confident that the pupils would so acquit themselves as to recommend the school and its system. In this be was not disappointed. The reading of the boys; their acquaintance 
with the elements of English grammar, geography and arithmetic; the manner in which they explaincd words and sentences, and illustrated their meaning by apposite examples; the promptitude and accuracy with which they answered the questions put to them-all took the auditors by surprise and filled them with admiration, seeing that the school had been only a twelvemonth in operation. But what astonished them most of all in those early days was the ease and freedom with which the Hindoos read such portions of the Bible as were named to them, as well as the readiness and accuracy with which they answered all questions, not merely on the historical parts but on the doctrines and principles of the Christian faith and morals, to which their attention had been directed in the daily lessons.

Altogether the effect produced by that examination was very striking. By those present it was pronounced absolutely marvellous. The three daily English newspapers of Calcutta had their reporters present, who gave such accounts of the examination and the new and felicitous modes of instruction pursued in the school, that European Calcutta talked of nothing else. The opinions of the English residents, official and independent, reacted on the leaders of the native community, till in the second year hundreds were refused admittance to the school from want of accommodation, and the number of European visitors interfered so seriously with the regular discipline of the classes that Saturday was set apart for such inspection. The elder pupils now consented to act as monitors, native assistants pressed their services upon the missionary, and the elementary teaching fell to these as the English classes passed on to collegiate studies in sacred and secular truth.

There was another immediate result. Dr. Inglis 
and the Edinburgh committee had their desire as to a school in the interior. While visitors from all parts of India, including far Bombay as we shall see, carried away with them the principles of the system to establish schools elsewhere, Mr. Duff was implored to open a similar school at the purely Bengalee town of Takee, forty miles off. There was the ancestral seat of Kaleenath Roy Chowdery, one of the principal followers of Rammohun Roy. $\mathrm{He}$ and his brothers offered all the buildings and appliances for an English, Bengalee and Persian school, to be supervised by $\mathrm{Mr}$. Duff, and taught by men of his own selection and on his own Christian system, whom in the Bengalee and Persian departments the brothers would pay. The triumph was complete. There a vigorous mission school arose, long conducted by the Rev. W. C. Fyfe, now head of the Calcutta Mission, and aided by Dr. Temple, whose widow (now Mrs. W. S. Mackay) and family have ever since been most closely identified with spiritual and mission work. The examination of the school and the example of the Chowdery family led not a few of their wealthy co-religionists in Calcutta to open new schools or improve the old mechanical establishments.

At this time Mr. Duff supplied the Hindoo reformer with the following letter of introduction to $\mathrm{Dr}$. Chalmers. Had they met during the brief remainder of Raja Rammohun Roy's life, which was spent almost exslusively in the society of English Unitarians, the sympathetic Christian divine, who had himself passed through the last spiritual conflict left for the truthseeking Hindoo, might have led him to the only wise God, the Saviour. As it was, the Raja died in 1833, declaring that he was neither Christian, Muhammadan, nor Hindoo. To the last he preserved his caste, that be might secure his civil rights of property and in. 
heritance and retain his nationality. His best biographer pronounces him "a religious Benthamite."

" Calcutta, College Sqdare, 18th Nov., 1830.

"My Dear Sir,-This may probably be delivered to you by the celebrated Rammohun Roy. His general character and acquirements are too well known to require any description on my part. And when I say that he has rendered to me the most valuable and efficient assistance in prosecuting some of the objects of the General Assembly's Mission, I feel confident I have said enough to secure from you towards him every possible attention in your power. Any further particulars illustrative of the accompanying document, which is a copy of what I originally inserted in a religious periodical published in Calcutta, you, as a member of the Assembly's committee, may learn from Dr. Inglis. I would write to you more frequently and more fully, were it not that I ever cherish the impression that whatever is addressed to Dr. Inglis, as chairman of the Assembly committee, is equally addressed to every individual member of it. Remember me kindly to Mrs. Chalmers and family. Yours most sincerely and gratefully,

"Alexander Duff."

Dr. Inglis and the Church of Scotland, sorely tried by the disasters which befell the first missionary, and even before they could learn his safe arrival at Calcutta, determined to pursue their original plan of sending out two colleagues to assist him whom they had appointed "the head master of a seminary of education with branch schools." One was most happily found in a tall, slightly bent and pale youth from Thurso, who, having studied at Aberdeen University, completed his course at St. Andrews a year after Duff, but in time to know well the man whom be ever 
afterwards worked along with in loving harmony. The Rev. W. S. Mackay, who joined the infant mission in the autumn of 1831, was so accomplished and elegant a scholar that it is difficult to say whether he became more remarkable as a learned theologian, as a master of English literature and style, or as an astronomer. A lofty and intense spirituality marked all his work, and only a robust physique was wanting to him. But even his assistance was not enough, as the school developed into a college, and branch schools like Takee demanded organization and supervision, while other duties than that of daily teaching denied the missionary a' moment's leisure. Competent lay teaching of secular subjects was required, and for this the acute but imitative Bengalee intellect had not yet been sufficiently trained.

Mr. Duff thus found his first English assistant. Among the passengers of the Moira was a Mr. Clift, the son of an English squire, who was going out to one of the great mercantile houses of Calcutta. Being of a combative disposition he was placed by the captain next to the missionary, who soon discovered that he was highly educated and well read, especially in the then little studied science of political economy. On the failure of the firm in which the youth became an assistant, he sought the advice of Mr. Duff, who at once offered him the position of assistant master on sixty pounds a year-the highest salary he was empowered to give, but invited him to his house as a guest. Mr. Clift did his work in the higher classes well. In the house his conduct was upright, and at least respectful in reference to religion, on which, however, he maintained a studied silence. He was sent to the Takee branch school as its first master. Thence he returned, stricken with jungle fever, to the tender ministrations of Mrs. Duff. In the delirium of the 
disease he was heard repeating Cowper's hymn, "There is a fountain filled with blood." As he recovered he confessed that he had been trained by pious parents, and that he had led a careless life. He became a changed man on his return to Takee, from which Government took him subsequently to make him principal of an English college. The incident powerfully confirmed the young missionary in his conviction of what was then little recognised in educational systems, the importance of saturating the young mind with divine truth.

But the episode has a twofold interest apart from that. This youth was only one of many of that class of adventurers who, like Meadows Taylor in Western India, and hundreds of well-educated lads who enlisted in the East India Company's Artillery especially, sought in service in the East, mercantile, military and uncovenanted, the career denied to their roving and romantic spirits elsewhere. Sir Henry Lawrence, after he published his marvellous sketch of the lives of such military adventurers in the Punjab,* more than once promised us to write a book on the prominent English, Scotch and Irish adventurers in India, for none knew them so well seeing that none assisted them so generously. But Mr. Clift had even a closer interest for Alexander Duff, introduced as the missionary had been into the practical and theoretical teaching of political science by Dr. Chalmers, who had in Glasgow just before given a new illustration of the meaning and the working of economics in the highest sense. In his determination to use all truth for the good of the people of India, and through it to

- Adventures of an Cffioer in the Service of Runjeet Singh, by Major H. M. L. Lawrence, Bengal Artillery: 1845. 'Tho book is now as rarc os it is valuable. 
educate them to recognise and love the highest truth, Duff projected a manual of political economy more elementary than the writings of Adam Smith and J. R. McCulloch. Even at the outset he began to suspect, what every year and many a woful blunder like the mortality of the Orissa famine have since proved, that without the data supplied by the old civilizations, the so-called 'pre-historic' customs and the social systems of the East, political economy must be partial in its generalizations and one-sided in its principles. Still, even as it was in 1831, the science might be a powerful armoury against the caste, the social exclusiveness, the commercial apathy, the industrial antipathy, which marked the Hindoos.

Recalling his talk at the cuddy table of the Moira, Duff proposed to Mr. Clift the drafting of such a manual. The manuscript he expanded with new illustrations and vivid contrasts, all leading up to Christian teaching. The book became most popular, as taught in the spirit in which it was written. Thus Mr. Duff's school was the first in which political economy was expounded in a country where, indeed, the Permanent Settlement of Cornwallis and the famous 'Fifth Report' had groped in the dark after a just and selfdeveloping system of land revenue and treatment of land tenures; but where Holt Mackenzie and Mertins Bird, Thomason and John Lawrence were yet benevolently to dogmatize in favour of thirty years' leases, which each changing Government uses to screw more and more out of the peasantry, and thus chiefly makes them unable to withstand famine when it comes. But the story is not complete. So little had political economy been mastered in the land of Adam Smith and in the kirk of Thomas Chalmers, that the committee condemned the enthusiastic missionary, when he joyfully reported his success, for teaching a subject 
which the monopolist Government of the East India Company might confound with politics!

Alexander Duff was not only in the citadel of Hindooism; he had already dug his mine and laid the powder. The fire from heaven was about to fall, as he invoked it in the prayer of Lord Bacon : - " To God the Father, God the Word, God the Spirit, we pour most humble and hearty supplications; that $\mathrm{He}$, remembering the calamities of mankind, and the pilgrimage of this our life, in which we wear out days few and evil, would please to open unto us new refreshments out of the fountains of His goodness for the alleviation of our miseries. This also we humbly and earnestly beg, that human things may not prejudice such as are divine; neither that, from the unlocking of the gates of sense, and the kindling of a greater natural light, anything of incredulity or intellectual night may arise in our minds towards divine mysteries. But rather that,-by our mind thoroughly cleansed and purged from fancy and vanities, and yet subject and perfectly given up to the divine oracles, - there may be given up unto faith the things which are faith's.-Amen."

- Quoted in India and India Missions as the "appropriate cap. clusion" of the book. 


\section{CHAPTER VI.}

\section{$1831-1833$.}

\section{THE FIRST EXPLOSION AND THE FOUR CONVERTS.}

Eagerness of the Bengalee Yonth to learn English.-Self-evidencing Power of Christ's Teaching.-The Pharisees of Brahmanism. -The Disintegrating Effect of true Science.-The Cry raised of "Hindooism in Danger."-Projected Conrse of Lectures.Derozio and the Atheists of the Hindoo College.-Tom Paine the favourite Author.-The first and only Lecture.-The City in an Uproar.-The Governor-General privately Encuurages the Missionary.-Duff studying Bengalee.-First propounds national system of Female Edncation.-The Debating Societies.-Robert Burns on the banks of the Ganges. -The Native Press, English and Vernacular.-Krishna Mounn Banerjea - Second Course of Lectures.-Mohesh Chunder Ghose, the First Convert, brings his Brother to Christ.-Confessions of Krishna Mohnn and his Baptism.-The Third or Martyr Convert. - The Fourth Convert at last Surrendered by his Father to Duff. - Origin of the Calcutia Missionary Conference.-Duff's great scheme of a United Christian College foiled by sectarian controversy in England.-A Bombay Civilian's Picture of the Revolntion in Bengalee society. -Duff's privalo estimate of his Snccess and faith in his Policy. -The English Language and British Administration required to do their part.

"Throdghout the whole progress of these preparatory arrangements," Mr. Duff afterwards wrote, "the excitement among the natives continued unabated. They pursued us along the streets. They threw open the very doors of our palankeen, and poured in their supplications with a pitiful earnestness of countenance that might have softened a heart of stone. In the most plaintive and pathetic strains they deplored, their ignorance. They craved for 'English reading' - English knowledge.' They constantly appealed to 
the compassion of an 'Ingraji' or Englishman, addressing us in the style of Oriental hyperbole, as 'the great and fathomless ocean of all imaginable excellences,' for having come so far to teach poor ignorant Bengalees. And then, in broken English, some would say, 'Me good boy, oh take me ;' others. ' Me poor boy, oh take me ;'-some, 'Me want read your good books, oh take me;' others, 'Me know your commandments, Thou shalt have no other gods before Me, - oh take me ;'-and many, by way of final appeal, ' Oh take me, and I pray for you.' And even after the final choice was made, such was the continued press of new candidates that it was found absolutely necessary to issue small written tickets for those who had succeeded; and to station two men at the outer door to admit only those who were of the selected number."

Payment for class-books, and the formal signature by parents and guardians of an agreement to secure punctual and regular attendance, struck at the root of two evils which marked all the other schools and colleges in Calcutta. The more severe test of steady attention to the Bible studies was no less cheerfully submitted to, parents also being invited to listen to the hour's preaching to the young every day, and to satisfy themselves that Christianity did not act as a spell, although it might in time persuade as a divine force co-operating with the truth-seeking soul; and was in any case a perfect system of moral principles and practice. The Lord's Prayer was succeeded by the master parable of the Prodigal Son, and then came the apostolic teaching to the Corinthians on what our fathers called charity.

"Throughout, all were attentive; and the minds of a few became intensely riveted, which the glistening eye and changeful countenance, reflecting as in a 
mirror the inward thought and varying emotion, most clearly indicated. At last, when to the picture of charity the concluding stroke was given by the pencil of inspiration in the emphatic words 'endureth all things,' one of the young men, the very Brahman who but a few days before had risen up to oppose the reading of the Bible, now started from his seat exclaiming aloud, ' $\mathrm{Oh}$, sir, that is too good for us. Who can act up to that? who can act up to that?' A finer exemplification, taking into view all the circumstances of the case, could not well be imagined of the self-evidencing light of God's holy word. It was an almost unconscious testimony to the superior excellence of Christianity, extorted from the lips of an idolatrous Brahman by the simple manifestation of its own divine spirit. It was a sudden burst of spontantous homage to the beauty and power and holiness of the truth, in its own naked and unadorned simplicity, at a moment when the mind was wholly untrammelled and unbiassed by prejudice, or party interest, or sect."

Then followed the Sermon on the Mount, which drove home to a people more enslaved by the letter that killeth than even those to whom it was originally addressed, the lesson of the Spirit. "When, on one occasion, the question was put, "What do you mean by Pharisee?' a boy of inferior caste, looking significantly at a young Brahman in the same class and then pointing to him, archly replied, ' $\mathrm{He}$ is one of our Pharisees!'-while the Brahman simply retorted in great good humour, 'True, my caste is like that of the Pharisees, or worse; but you know $I$ am not to be like my caste." "'

Nor was this all. From the simple reading of the words that promise blessedness to him who loves and prays for his enemy, one youth was turned to the feet of the Divine Speaker and became the fourth convert 
of the mission. For days and weeks the young Hindoo could not help crying out, " "Love your enemies! bless them that curse you!' How beautiful! how divine! surely this is the truth!" And in the more directly secular lessons science came to carry on what grace had begun in the morning and was yet to complete. The explanation of the word "rain" on the Scoto-Socratic method in a junior class, led to the discovery by the lads of its true nature, as neither Indra-born nor from a celestial elephant, according to the Shasters, but the result of natural laws. "Then what becomes of our Shaster, if your account is true," remarked a young Brahman. "The Shaster is true, Brahma is true, and your Gooroo's account must be false-and yet it looks so like the truth."

This was but a slight shock compared with that given on the next eclipse. Mr. Duff was himself as much surprised by the effect of his teaching as his pupils. He wrote of this time:- "Though we were previously acquainted in a general way with the fact, that modern literature and science were as much opposed as Christianity itself to certain fundamental tenets of Hindooism, our own conception on the subject was vague and indeterminate. It floated in the horizon as an intangible abstraction. Now this incident, by reducing the abstract into the concrete, by giving the vague generality a substantial form, by converting the loosely theoretical into the practically experimental,-at once arrested, fixed and defined it. A vivid glimpse was opened, not only of the effect of true knowledge when brought in contact with Hindooism, but of the modus operandi, the precise mode in which it operated in producing the effect."

The effect of the first year's teaching, Biblical, scientific, and literary, through English and through Bengalee, on even the young Hindoos, was to load 
them into licence befure they could reach true selfregulating liberty; for the Bengalee boy just before or at the age of puberty is the most earnest, acute and loveable of all students. The older lads, "impetuous with youthful ardour and fearless of consequences, carried the new light which had arisen on their own minds to the bosom of their families, proclaimed its excellences on the house-tops, and extolled its praises in the street-assemblies. With the zeal of proselytes they did not always observe circumspection in their demeanour and style of address, or manifest due consideration for the feelings of those who still sat in darkness. Even for the infallible Gooroos and other holy Brahmans, before whom they were wont to bow in prostrate submission, their reverence was greatly diminished. They would not conceal their gradual change of sentiment on many vital points. At length their undaunted bearing and freedom of speech began to create a general ferment among the staunch adherents of the old faith. The cry of "Hindooism in danger' was fairly raised."

The result was seen one forenoon, when only half a dozen of the three hundred youths appeared in the class-room. To the question of the puzzled missionary the only reply was a copy of that morning's Chundrika. This Bengalee paper had been established to fight for the sacred right of burning living widows with their dead husbands. Now, as the organ of the orthodox Dharma Sobha, of which its editor was secretary, it had become the champion of the whole Bralmanical system against an aggressive evangelical Christianity of a very different type from the secularism of the Hindoo College with which it had of late been allied. The decree went forth that all who attended the General Assembly's Institution were to be excluded from caste, and it was urged that a yellow flag or 
other unmistakable symbol should be planted in front of the building to warn the unwary against the moral and religious pestilence. But the Hindoo society of the capital had already become too rationalistic in its mode of viewing the national faith, and too selfish in its desire to secure the best education which would lead to official and mercantile appointments. The panic did not last a week. The Holy Assembly had no greater power than public opinion chose to give it. Further diatribes against the missionary and his work revealed only the essential weakness of a body which the earlier reforms of Rammohun Roy had provoked into existence. Mr. Duff went calmly on till the classes became more crowded than ever. The quietness and confidence of an assured faith and an intellectual conviction were seen in his drawing up, after the experience of the first six months, "the scheme of a complete educational course which might require nine or ten years for its development, with grounds, reasons and illustrations" occupying in all about a hundred closely written folio pages. This he sent off to Dr. Inglis as the mechanism of the Christian Institute to regenerate Bengal and light a fire in British India, from which ever since many a torch has been kindled to help in the destined destruction of every form of error.

The college thus securely established in native society, triumphing over the ignorance of his own countrymen and already famous throughout India, Mr. Duff proceeded to use at the same time the two other more immediately powerful weapons of lectures and the press. The minds of not a few leading Hindoos had been emptied of their ancestral idols spiritual and ecclesiastical, and were swept and garnished. Into some, thus deprived of even the support which the ethical elements of their old orthodoxy supplied, the new 
demons of lawless lust and Western vice had entered with the secularism and anti-theism of the Hindoo College, so that their last state was worse than the first. Others, saved for the hour from this, were in the temporary attitude of candid inquirers, bold to violence in their denunciation of the follies of which they and their fathers had long been the victims, but timid towards the new faith, with its tremendous claims on their conscience and irresistible appeals to their intellect. In May, 1829, the teaching of a Eurasian of some genius and much conceit, named Derozio, had begun to undermine the faith of the students of the Hindoo College in "all religious principles whatever," as even its secularist managers expressed it. Hence they formally resolved that Mr. D'Anselme, the head-master, "in communication with the teachers, check as far as possible all disquisitions tending to unsettle the belief of the boys in the great principles of natural religion." This interference only fanned the smouldering fires. Discussion blazed out into ridicule. Young Brahmans refused to be guilty of the hypocrisy of submitting to investment with the poita, or sevenfold Brahmanical cord; many substituted favourite lines of Pope's "Iliad" for their daily and festival prayers. In February, 1830, seeing that the Hindoo College was thus threatened with extinction, although all that was going on was only the logical outcome of their principles and their administration, the managers threatened with immediate dismissal teachers who did not "abstain from any communications on the subject of the Hindoo religion with the boys," or who suffered "any practices inconsistent with the Hindoo notions of propriety, such as eating or drinking in the school or class-rooms."

By April, 1831, the ferment had so increased that Mr. Derozio was discharged as " the root of all evils and 
cause of public alarm." Students of "the dining party," who had broken caste by eating animal food, or food with Hindoos of other castes than their own, were removed; and it was determined that " such books as may injure their morals should not be allowed to be brought, taught, or read in the college." This was what fifteen years' teaching of English and Sanscrit, by the East India Company and orthodox Bengalees combined, at the bidding of Parliament which sought the moral and spiritual elevation of our native subjects, had resulted in. The unhappy Derozio, whose end was even sadder than his life which might have reflected lustre on the valuable but then uncared for community of Eurasians, was charged with inculcating "the non-existence of God, the lawfulness of disrespect towards parents, the lawfulness of marriage with sisters." He admitted the first, but pleaded that his chief object had been to enable the boys "to examine both sides of the question." Mr. Hare still was of opinion that he was a highly competent teacher; and Dr. H. H. Wilson, the official visitor on the part of Government, which spent the public funds on the place, declared he had never observed any ill effects from Derozio's instructions. But the atheistic and immoral poet was dismissed in deference to the clamours of the orthodox idolaters, although the principal English text-books, taught by men in quite as full accord with them as he, were the more licentious plays of the Restoration and David Hume's Essays!

Outside of the classes, but constantly referred to by the teachers, the favourite book was Paine's coarse "Age of Reason," which a respectable deist would not now mention save as a warning. That book, his better reply to Burke, his "Rights of Man," and his minor pieces born of the filth of the worst period of the French Revolution, an American publisher issued in a cheap octavo 
edition of a thousand copies, and shipped the whole to the Calcutta market; such was the notoriety of the anti-christian success of the college which Rammohun Roy was ashamed to patronise. These were all bought at once at two shillings a copy, and such was the continued demand for the worst of the treatises that eight rupees (sixteen shillings) was vainly offered for it.* Thus, from the opposite poles of truth, were the two English colleges-the old secularists' and the new evangelical missionary's-brought into collision, as the former retired foiled in its assault on Hindooism, and the latter advanced with renewed trust in the God of truth to fire the train. Unlike the horror-stricken but passive Christian preachers in the vernacular chapels and schools of Calcutta at that time, the young Scotsman threw himself into the breach made in the at last crumbling walls of Hindooism. "We rejoiced," he wrote, "in June, 1830, when, in the metropolis of British India, we fairly came. in contact with a rising body of natives, who had learnt to think and to discuss all subjects with un-. shackled freedom, though that freedom was ever apt to degenerate into licence in attempting to demolish the claims and pretensions of the Christian as well as every other professedly revealed faith. We hailed the circumstance, as indicating the approach of a period for which we had waited and longed and prayed. We hailed it as heralding the dawn of an auspicious era,- - an era that introduced something new into the hitherto undisturbed reign of a hoary and tyrannous antiquity."

Having by his first year's work of teaching and personal influence carried on this work of preparation for calm inquiry, he took three men of like spirit with

- Calcutta Christian Observer for August, 1832. 
himself into his counsels. Dr. Dealtry, who succeeded Corrie first as Archdeacon of Calcutta and then as Bishop of Madras, was at that time chaplain of the Old Church, and was worthy of such predecessors as Martyn and Claudius Buchanan. John Adam had been his own fellow-student at St. Andrews, and was then of the London Missionary Society. Mr. James Hill, also a Congregationalist, was the popular and able pastor of that Union Chapel in which Christians of all sects still gather on the first day of every year for catholic communion, after a fashion too rare in divided Cliristendom. All were eager observers of native progress, and agreed to co-operate in delivering the first course of lectures to educated Bengalees. The subject was Natural and Revealed Religion. The first lecture, on the External and Internal Evidences, fell to Mr. Duff; Mr. Adam undertook the second, on the testimony of History and Fulfilled Prophecy; Mr. Hill was to prepare the third, on Christ in the Four Gospels, and the Genius and Temper of His Religion. Dr. Dealtry was to close the course with a statement of the doctrines of Christianity. But to prepare the native mind for unprejudiced inquiry, Mr. Hill delivered an introductory lecture on the moral qualifications necessary for investigating truth. Mr. Duff fitted up a lecture room in his house, which, being still in College Square, was most central for the class invited. To some that room became the place of a new birth, and its memories still hallow the similar work, on the same site, of the Church Missionary Society.

It was a sultry night in the first week of August when twenty of the foremost students of his own and of the Hindoo College took their places in expectation of a novel exposition. With the chastened eloquence which used to attract the Governor-General and his 
wife to the dissenting chapel, Mr. Hill treated a subject that called forth no controversy, and appealed to admitted but too often neglected principles. In silence the young men separated, looking forward to the real tug of war a week after in Duff's lecture on God and His Revealing. That never took place.

Next morning the news flew like wildfire over Calcutta. Students of the Hindoo College had actually attended, in the house of a missionary, a lecture on Christianity! Soon the whole city was in an uproar. The college that day was almost deserted. Continuing to rage for days the orthodox leaders accused the Government itself of breach of faith. Had it not promised to abstain from interference with their religion, and now insidiously it had brought out a wild Padre, and planted him just opposite the college, like a battery, to break down the bulwarks of the Hindoo faith and put Christianity in its place! In all haste, Dr. H. H. Wilson, Mr. Hare, Captain Price and the native managers put up a notice threatening with expulsion students who should attend " political and religious discussions." That was the degree of their love of truth. The students themselves remonstrated. Mr. Hill published an indignant exposure of the misrepresentation and cowardice of the college authorities; and Mr. Duff at greater length assailed the wisdom, justice and goodness of their tyrannical decree. But he was not the man to rashly imperil the cause in which, like the first missionary, it behoved him to be all things to all men if thereby he might win some. That was still the time of the East India Company's absolutism, when the GovernorGeneral had the right of deporting non-official settlers without assigning reason. Not so very long before, the able civilian John Adam had gagged the press and ruined, by deporting, Mr. J. Silk Buckingham, to 
appease Dr. Bryce and the John Bull newspaper. The very existence of the mission might be at stake, and prudence at least demanded that all the facts should be known to the Government, if only that the missionary might be assured that it shared none of the Company's ignorant fears.

Mr. Duff, therefore, thought it right to solicit a private interview with the Governor-General. Lord William Bentinck listened with the utmost attention and patience. At the close of the statement he said in substance: Assuming the accuracy of the facts which he could not possibly doubt, he felt that Mr. Duff had done nothing to contravene the law, nothing that ought to disturb the public peace. At the same time he added, from his knowledge of the Hindoo character, that it would be well to allow the present tumult quietly to subside. After a time it might be in $\mathrm{Mr}$. Duff's porver more successfully to renew the attempt. So far as he himself was concerned, he could not, as Governor-General, in any way mix himself up with missionary affairs, or even officially express sympathy and approval. But he declared that privately, as an individual Christian man, he felt deep sympathy with the arowed object of the missionaries, aud approved of the operations of all who carried them on in the genuine spirit of the gospel. He who had been Governor of Madras during the Vellore mutiny, repeated the advice patiently to wait for a seasonable opportunity to recommence what, if Mr. Duff went about it calmly yet firmly, he himself would advance by his private sympathy and support.

This for the moment answered the purpose; fear and alarm were abated. The most advanced students, however, though having no good-will to Christianity, but the contrary, felt that this was a violent interference with their freedom and independence.

They 
winced under the order, and boldly declaimed against the bigotry and tyranny of the college and the Government authorities. They seemed to champ like horses prepared for battle when forcibly kept back by bit and bridle. Still from policy or necessity they deemed it expedient to submit to what they reckoned a despotic exercise of authority.

Being thus for a time freed from the task of prepar. ing lectures in addition to his heavy school work, Mr. Duff energetically set about mastering the Bengalee language by the help of a learned Bralıman pundit. By the end of a twelvemonth he succeeded so as to speak it with tolerable fluency. He wrote out for the sake of accuracy and committed to memory his first sermon in Bengalee. But regular preaching in the vernacular he did well to leave to others, who gave their whole strength to a work specially adapted to meet a very different class from those who held the inner fort of Brahmanism. Denied lectures, the young men met in debating societies of their own. These, often nightly and in various quarters of the city, he asked permission to attend, and soon an address from him was welcomed as an attractive part of the proceedings. There it was that he first formulated his far-seeing policy on the subject of female education, from which Government still directly keeps back its hand, though aiding the tentative efforts of missionaries.

At that time Miss Cooke, who became the wife of the Church missionary, Mr. Wilson, had been teaching the first female school in Bengal for eight years. She had been led to form it by a visit paid to one of the boys' schools of the Calcutta School Society, in order to observe their pronunciation of the vernacular, which she was learning. Seeing the pundit drive away a wistfuleyed little girl from the door, she was told that the child had troubled him for the past three months with 
entreaties to be allowed to read with the boys. Next day, on the 28th January, 1822, she opened her first school with seven pupils, and in a year, with the help of the noble Countess of Hastings, the GovernorGeneral's wife, she had two hundred in two schools. The Serampore three had, as usual, anticipated even Mrs. Wilson by their Female Juvenile Society. But at that early period and long after, the few hundred girls under the only partial and brief instruction allowed them before very early marriage, formed but units, and were of a class similar to those reached by the street and village preacher. Many were bribed by money to attend. The middle and higher classes, whose sons Mr. Duff had attracted to his own school and was daily influencing by personal intercourse, were shocked at the idea of educating their wives and daughters; and even if they had consented, as many now do, would not let them out of the home-prison of the zanana.

But these youths thought differently, and Mr. Duff encouraged them. One evening he found the subject of debate by some fifty Hindoo College students to be, "whether females ought to be educated." As to the theory of the thing they ended in being unanimous; one married youth exclaiming, "Is it alleged that female education is prohibited, if not by the letter, at least by the spirit of some of our Shasters? If any of the Shasters be found to advance what is so contrary to reason, I, for one, will trample them under my feet." The brave words won rapturous plaudits for the speaker. As these youths became fathers and grandfathers, female education would spread of itself, if the Christian Church supplied the vernacular and English lady teachers. Hence Mr. Duff's conclusion, as he listened to the vaporous but not insincere talk of these fledglings: "Over the pre. 
sent (1830-40) generation little or no control can be exercised by these youths. But as time rolls on they become the heads of families themselves, and then will they be prepared, in many instances at least, to give practical effect to their better judgment." He dreamed, he talked, he almost lived to be witness of "the halcyon period when universal theory shall run parallel with universal practice," in instructing the women of the great educational centres of India. And we shall see how ready he was to play his part in the practice when he had done the preparatory work of educating the husbands and the fathers.

It was of societies where such questions were discussed that a vernacular newspaper exclained, "The night of desolation and ignorance is beginning to change its black aspect, and the sky, big with fate, is about to bring forth a storm of knowledge which will sweep those airy battlements away that have so long imprisoned the tide of thought." But social questions were not all. These were the days when the first echoes of the English Reform Bill agitation began to reach Anglo-Indian newspapers. In the native mind the constitutional progress of the English Whigs came to be mixed up with the frothy Republicanism of their familiar Tom Paine, and the sensus communis of Reid and the Scottish school of philosophy with that blasphemer's favourite name of "common sense." An education which, in the Government colleges, long after continued to fill the memories of the students with the best-sometimes with the worst-passages of the English poets, had made quotation the mark of culture and elegance in a young debater. They liad not mastered Shakespeare or Shelley as now, but Sir Walter Scott, Byron and even Robert Burns were their favourites. "More than once," writes Duff of that time, "were my ears greeted with the sound of 
Scotch rhymes from the poems of Robert Burns. It would not be possible to portray the effect produced on the mind of a Scotsman, when, on the banks of the Ganges, one of the sons of Brahma,-in reviewing the unnatural institution of caste in alienating man from man, and in looking forward to the period in which knowledge, by its transforming power, would make the lowest type of man feel itself to be of the same species as the highest,- - suddenly gave utterance, in an apparent ecstasy of delight, to these characteristic lines :-

' For a' that, and a' that, Its comin' yet, for a' that, That man to man, the world o'er, Shall brothers be, for a' that.'

How was the prayerful aspiration raised, that such a consummation might be realized in a higher and nobler sense than the poet or his Hindoo admirer was privileged to conceive!"

But it was time, after all this experience of the variously mixed material on which he was to work, to come to close quarters with Young Bengal; to build a spiritual temple on the foundation thus cleared and almost crying out, as in a very similar transition state the young and erring Augustine cried, "O Truth, Truth! how eagerly even then did the marrow of my soul pant after thee!"

The traditional idolaters and the liberal inquirers had become separated farther and farther from each other, by that gulf which even here marks off the love of the true from the tendency to the false. The liberals established their own English journal, well naming it the Enquirer. Long before, Rammohun Roy had set the English Reformer on foot; but it had committed itself to reproducing the antichristian attacks of Paine 
after its founder had left for England, and it was assisted in this by Englishmen who called themselves Christians. The English of the Enquirer, and the Bengalee of the Gyananeshun, week after week attacked Hindooism and its leaders with a courage and skill that called down on the editors the execrations of their countrymen. But all besides was negative. The Reform Bill was eagerly turned to in July, 1831, for a positive something to rejoice in as the germ of a new reformation which would sweep away tyrants and priests. The Holy Congregation's threat of excommunication was met with this welcome: "Be some hundreds cast out of society, they will form a party, an object devoutly to be wished by us!" The man who proved a more than worthy successor of Rammohun Roy and sounded those trumpet notes in the Enquirer. was be who is now and has long been the staid scholar and the grave minister of the Church of England, the Rev. Krishna Mohun Banerjea, LL.D. Then he was a Brahman of the highest or Koolin class, legally entitled to marry all the women who might take hold of him to be called by his name, and with the certainty of becoming, in Hindooism, a Pharisee of the Pharisees.

Duff has himself told the story of that act by which the truth-seeking Koolin formed the party of progress which he desired. Krishna Mohun happened to be absent from a meeting of the liberal party held in his family house on the 23rd of August, 18:31.

"If there be anything on which a genuine Hindoo is taught, from earliest infancy, to look with absolute abhorrence, it is the flesh of the bovine species. If there be anything which, of itself singly, must at once degrade a man from his caste, it is the known participation of that kind of food. Authentic instances are on record, wherein a Brahman, violently seized by a 
Moslem, has had such meat forced into his mouth; and though deprived of voluntary agency as much as the veriest automaton, the contamination of the touch was held to be so incapable of ablution, that the hapless, helpless, unwilling victim of intolerance, has been actually sunk along with his posterity for ever into the wretched condition of outcast. Well, in order to furnish the most emphatic proof to each other of their mastery over prejudice and their contempt of the ordinances of Hindooism, these friends of liberty had some pieces of roasted meat, believed to be beef, brought from the bazaar into the private chamber of the Enquirer. Having freely gratified their curiosity and taste with the unlawful and unhallowed food, some portion still remained, which, after the return of the Enquirer, was thrown, though not with his approbation, in heedless and reckless levity into the compound or inner court of the adjoining house, occupied by a holy Brahman, amid shouts of- There is beef ! there is beef!' The sacerdotal master of the dwelling, aroused by the ominous sound and exasper. ated at the unpardonable outrage which he soon found had been perpetrated upon his feelings and his faith, instantly rushed with his domestics to the quarter whence it proceeded, and under the influence of rage and horror, taking the law into his own hands, he violently assaulted the Enquirer and his friends.

" Knowing that they had been guilty of an action which admitted of no defence the latter confessed their criminality, uniting in apologies for the past and promises of amendment for the future. But neither confession nor apology nor promise of amendment would suffice. The openly avowed opinions and conduct of the Enquirer and his friends had long been a public scandal and offence in the eyes of their bigoted countrymen; and, short of formal excommunication, 
they were in consequence subjected to all manner of persecution. But the crisis-the hour of unmitigated retribution-had now arrived. Hundreds speedily rallied around the Brahman, the sanctuary of whose home had been so grossly violated by the presence of the abomination of abominations. Inflamed with uncontrollable indignation, they peremptorily demanded of the family of the Enquirer to disown him in the presence of competent witnesses, under pain of expulsion from caste themselves. Having no alternative, his family then called upon him formally to recant his errors, and proclaim his belief in the Hindoo faith, or instantly to leave the home of his youth, and be for ever denuded of all the privileges and immunities of caste. $\mathrm{He}$ chose the latter extremity. Accordingly, towards midnight, without being able to take formal leave of any of his friends, he was obliged to take his departure he knew not whither, because he could not be prevailed upon to utter what he knew to be false. 'We left,' wrote he, ' the home where we passed our infant days; we left our mother that nourished us in our childhood; we left our brothers with whom we associated in our earliest days; we left our sisters with whom we sympathized since they were born.' As he and his friends were retiring, the infuriated populace broke loose upon them, and it was with some difficulty they effected their escape and found shelter in the house of an acquaintance."

Recovering from the fever that followed, young Banerjea returned to the assault, but still had no positive truth to lean upon. "I was perfectly regardless of God," he wrote in the confessions of a later time; " yet, as a merciful Father, He forgot not me. Though I neglected $\mathrm{Him}$, yet $\mathrm{He}$ had compassion on me, and without my knowledge or inclination created, so to speak, a circumstance that impelled me to seek after 
Him." It was this. Unwilling to compromise the outcast further, Mr. Duff sent a native friend to invite him to his house. The confessions continue: "Mr. Duff received me with Cliristian kindness, and inquired of the state in which we all were. He openly expressed his sentiments on what we were about; and while he approved of one half of our exertions he lamented the other. $\mathrm{He}$ was glad of our proceedings against error but sincerely sorry at our neglecting the truth. I told him it was not our fault that we were not Christians ; we did not believe in Christianity, and could not therefore consistently profess it. The reverend gentleman, with great calmness and composure, said it was true that I could not be blamed for my not believing in Christianity so long as I was ignorant of it, but that I was certainly guilty of serious neglect for not inquiring into its evidences and doctrines. This word 'inquiring' was so uttered as to produce an impression upon me which I cannot sufficiently well describe. I considered upon my lonely condition-cut off from men to whom I was bound by natural ties, and thought that nothing but a determination on the subject of religion could give me peace and comfort. And I was so struck with Mr. Duff's words, that we instantly resolved to hold weekly meet. ings at his house for religious instruction and discussion." In the Enquirer he continued with growing boldness :- " Does not history testify that Luther, alone and unsupported, blew a blast which shook the mansions of error and prejudice? Did not Knox, opposed as he was by bigots and fanatics, carry the cause of reformation into Scotland? Blessed are we that we are to reform the Hindoo nation. We have blown the trumpet, and we must continue to blow on. We have attacked Hindooism, and will persevere in attacking it until we finally seal our triumph." 
Persecution drove the reformer to a European lodging-house, for not a native dared to shelter him. There, after narrowly escaping death by poison at the hands of their outraged families, his associates found him. And there Duff held earnest conference with them, as they debated the establishment of a Reformation Society, and the only one among them who had large property of his own offered it for the common cause. But convinced that, without some nobler truths to substitute for the system they destroyed, this would prove only an eradication society, the hot conspirators in the cause of religious freedom agreed to meet in the missionary's house every Tuesday, to study the claims of Christianity to be such a positive and lifegiving system as they now desiderated.

Hence the second course of lectures and discussions was carried on with ripe experience on the part of $\mathrm{Mr}$. Duff, who now preferred to keep it in his own hands; and was delivered to really earnest truth-seekers, many of whom had fairly separated from the idolatrous and caste system of their fathers. But still, at first, the Enquirer declared it had no religious doctrines to promulgate, only "let us have all a fair field, and adopt what reason and judgment may dictate." In a month the weekly discussions had brought its editor to the admission that theological truth is the most important of all, because of its practical influence on life, and that Christianity deserves special inquiry as having civilized a whole continent. "A reverend gentleman of the Presbyterian sect has undertaken the task of unfolding to us the nature of this set of doctrines." From forty to sixty seekers after God listened to each lecture, sat far into the night canvassing its statements, and either returned night after night for further inquiry or wrote out their difficulties for solution. The novelty of the weekly meeting drew many spectators, and some 
of these professedly calm inquirers proved to be "proud, forward, rude, boisterous and often grossly insulting.' But these were the exceptions, and they only stimulated the ardour without ruffling the perfect courtesy of the apostolic teacher, who had a yearning sympathy with every soul feeling after God, and knew that it is through much tribulation such must enter the kingdom. The record of these agonizings, intellectual and spiritual, forms a unique chapter in the history of the apologetics of those days. * As the demonstration of the existence and personality of the great First Cause called back the subtle spirit of the Bengalee, steeped in pantheistic polytheism, from its initial rebound into nihilism, the closing exhortations, delivered with all that tearful fervour which was soon to summon the Churches of the West to a new crusade, led them up to the great love of Christ and the influence of the Spirit.

Thus passed the cold season of 1831-32 in Calcutta. The work of John the son of Zacharias, was done. As his "Behold the Lamb of God!" sent Andrew to Christ, and Andrew "first findeth his own brother Simon . . and he brought him to Jesus," so was it now. At the conclusion of the discussions, Mohesh Chunder Ghose, a student of the Hindoo College, sent his own brother to Mr. Duff, with this note:-

"If you can make a Christian of him you will have a valuable one; and you may rest assured that you have my hearty consent to it. Convince him, and make him a Christian, and I will give no secret opposition. Scepticism has made me too miserable to wish my dear brother the same. A doubtfulness of the existence of another world, and of the benevolence of God, made me too unhappy and spread a gloom all over my

- Appendix to India and India Missions. 
mind; but I thank God that I have no doubts at present. I am travelling from step to step; and Christianity, I think, will be the last place where I shall rest; for every time I think, its evidence becomes too overpowering."

On the 28th August, 1832, the Enquirer announced the baptism into Christ of Mohesh himself, in an article which thus closed: "Well may Mr. Duff be bappy, upon the reflection that his labours have, through the grace of the Almighty, been instrumental in convincing some of the truth of Christianity, and others of the importance of an inquiry into it. We hope ere long to be able to witness more and more such happy results in this country."

For some unexplained reason this first convert of the General Assembly's Bengal Mission chose to receive baptism at the hands of an English chaplain whom he did not know. It is no cause for regret that the broad seal of catholicity was thus stamped on Mr. Duff's work, when his first son in the faith publicly declared his belief-" in spite of myself," as he said-in the triune God, in that old mission church which Kiernander had built and Brown and Martyn, Corrie and Dealtry had consecrated by their ministrations. It was thus that this first-fruit of his toil, in Mr. Duff's house and before many witnesses, after deep silence burst forth :-

“A twelvemonth ago I was an atheist, a materialist, a physical necessitarian; and what am I now? A baptized Christian ! A twelvemonth ago I was the most miserable of the miserable; and what am I now ? In my own mind, the happiest of the happy. What a change! How has it been brought about? 'The recollection of the past fills me with wonder. When I first came to your lectures, it was not instruction I wanted. Instruction was the pretext, a secret desire to expose what I reckoned your irrational and superstitious follies the reality. At last, against my inclinations, 
against my feelings, I was obliged to admit the truth of Christianity. Its evidence was so strong that I could not resist it. But I still felt contrary to what I thought. On hearing your account of the nature of sin, and esperially sins of the heart, my conscience burst upon me like a volcano. My soul was pierced through with horrible reflections and terrible alarms; it seemed as if racked and rent in pieces. I was in a bell of torment. On hearing and examining further, I began, I know not how or why, to find relief from the words of the Bible. What I once thought most irrational I soon found to be very wisdom; what I once hated most I soon began to love most; and now I love it altogether. What a change! How can I account for it? On any natural principle I cannot, for every step that I was made to take was contrary to my previous natural wish and will. My progress was not that of earnest inquiry, but of earnest opposition. And to the last, my heart was opposed. In spite of myself I became a Christian. Surely some unseen power must have been guiding me. Surely this must have been what the Bible calls 'grace,' free grace, sovereign grace, and if ever there was an election of grace surely I am one."

Krishna Mohun Banerjea himself was the next. He desired that the lecture room in the missionary's house, which had been "the scene of all my public opposition to the true religion, should also be the scene of my public confession of it." He sought that there his still Hindoo friends, who had been strengthened in their unbelief by his arguments, might witness his "public recantation of all error and public embracing of the truth, the whole truth, as revealed in the Bible." The Rev. Mr. Mackay opened that service with prayer. Mr. Duff addressed and thus interrogated the catechumen:- " "Do you renounce all idolatry, superstition, and all the frivolous rites and practices of the Hindoo religion?' To this the Koolin Brahman replied: 'I do, and I pray God that He may incline my countrymen to do so likewise.' The second question was: 'Do you believe in God the Father and Creator of all, in Jesus 
Et. 25. THE CONFESsions of The SECOND convert. I6I

Christ as your Redeemer, and in IIis sacrifice as the only means whereby man may be saved, and in the sanctifying influences of the Holy Spirit?' To this, with emotion, he replied, 'I do, and I pray God to give me His grace to do His will.' These and other questions being answered, Mr. Duff administered the ordinance in the name of the Father, Son and Holy Ghost; and then engaged in prayer, the whole company kneeling." Such was the description, in the daily newspaper of Calcutta, of the putting on of the yoke of Christ by the Koolin Brahman who, like another Saul of Tarsus, had made his name known and dreaded among thousands of his countrymen. By a different path from that of Mohesh Chunder, but along the in. tellectually thorny way of the Trinity from which many of his countrymen fall aside into their old polytheism, Krishna Mohun stumbled on to Him who is the Way, the Truth and the Life. His confessions have a typical interest for more than his own people and the students of ecclesiastical annals :-

"My attention having been particularly directed to the Socinian and Trinitarian systems, I at once felt more favourable to the former than the latter; but not seeing anything in it so great that it might reasonably call for the adoption of such extraordinary measures as those which Jesus employed for its propagation, I could not yield my conviction to it. On the other hand, I nnderstood not aright the doctrine of the atonement; and on grounds of mere natural reason could never believe it to be possibly true. And as the Bible pointed unequivocally to it, I strove to persuade myself, in spite of the most overpowering external evidence, not to believe in the sacred volume. Neither could I be satisfied with the forced interpretation of the Socinians. Socinianism, which seemed little better than Deism, I thought could not be so far above human comprehension that God should think of working such extraordinary miracles for its establishment. Accordingly, though the external evidences of the truth of the Bible were 
overwhelming, ret, because I could not, on principles of reason, be satisfied with either of the two interpretations given of it, I could not persuade my heart to believe. The doctrines of Trinitarian Christians, which I thought were really according to the plain import of Scripture language, were all against my feelings and inclinations. Socinianism, though consonant with my natural pride, seemed yet so insignificant, as a professed revelation, that I could not conceive how, with propriety, an all-wise God should work miracles for its sake. So that I remained in a state of doubt and perplexity for a long time; till God, by the infuence of His Holy Spirit, was graciously pleased to open my soul to discern its sinfulness and guilt, and the suitableness of the great salvation which centred in the atoning death of a Divine Redeemer. And the same doctrine of the atonement which, when not properly understood, was my last great argument against the divine origin of the Bible, is now, when rightly apprehended, a principal reason for my belief and vindication of the Bible as the production of infinite wisdom and love."

That baptism took place on the 17th October, 1832. In the same class-room, on a Tuesday evening, the 14th December, a third catechumen put on Christ. Gopeenath Nundi had sought a morning interview with Mr. Duff in his study, and there burst forth in tears with the cry, "Can I be saved?" He told how the last of the lectures had driven him to take counsel with Krishna Mohun Banerjea who prayed with him and sent him next morning to the missionary. At first imprisoned by his family, they cast him off for ever by advertisement in the newspaper; but nothing could shake his faith. Still, before the irrevocable step was taken, his brothers and caste-fellows implored him to desist, then foully abused him, and then offered him all that wealth and pleasure could give, including even the retaining of a belief in Christianity if only he would not publicly profess it. The last appeal was in the name of his venerable mother, whose piercing shriek 
none who have seen a Bengalee woman in sorrow can forget. The scene has often since been repeated, must yet be again and again witnessed before India is Christ's. Nature could not remain unmoved. Gopeenath wept, but throwing up his arms and turning hastily away he decided, "No, I cannot stay!" We shall meet the same true martyr's courage in him again, amid the captivity and the bloodshed of the Mutiny of 1857. He proved faithful unto death.

Nor was Anundo Chund Mozoomdar long left behind-the youth who in the school had been drawn by the divine power of the Sermon on the Mount. He had been the first to seek more detaiied instruction in the missionary's house. $\mathrm{He}$ had given up the family and caste and festival idol worship till a Cashmere Brahman, who had in vain remonstrated with him, naively complained to Mr. Duff himself that the gods had been blasphemed by the atheist Anundo. Of a wealthy family, he had declined to be married rather than submit to the ritual of Hindooism. Put out of caste, he only rejoiced in the new-found liberty, when his father, an official in Jessore, visited the capital. His uncle had written a vigorous protest against idolatry, and the father, though an orthodox Hindoo of what had now begun to be called the old school, liberally accepted the position, and wrote to Mr. Duff to receive the persistent Anundo as his son: "Convert him in your own way, and make him your follower." So, in St. Andrew's Kirk by the junior chaplain, Dr. Charles, Anundo was baptized, on Sunday, the 21st April, 1833, before the Scottish congregation and many awe-stricken spectators. Whether from the Hindoo College or from his own, it was by "the self-evidencing power of the word of God" that the joyful missionary saw these, his four spiritual sons, brought to the faith. 
With new confidence in his own fearless attitude towards truth in every form, and with assured trust in his systen ${ }_{1}$ which used all forms of truth as avenues by which the Spirit of God might be let in on the hoary superstitions of India, he set himself to perfect his organization. For the native church which he had thus founded on the one corner stone, and for catechumens, he opened a private week-day class to study systematically the doctrines of Christ in the minutest detail, and a Sunday class to read the Scriptures and hold communion with the Father in prayer. Having erected a bamboo and wicker-work chapel for vernacular preaching, he added to that an English service every Sunday evening. For inquirers outside Christianity, who had yet been won from atheism, he conducted successive courses of public lectures on the Bible, on the Socinian controversy, and on mental philosophy, followed by open discussions. Foiled at these, many changed the arena to the Bengalee newspaper. But pursuing them there, Mr. Duff advertised that he would answer each hostile article in good faith on the next lecture night, a procedure which gave a keen interest to the controversy in native society.

Thus within and without the work went on, while the school was every year developing into the famous college which it became with the aid of a colleague so able as Mr. Mackay, and of Eurasian assistants so faithful and earnest as Messrs. Sunder and Pereira. The administrative, the statesmanlike genius of Mr. Duff, had after its first examination seized the advantage of making it a still more catholic, central and efficient institute, by uniting in its support and management all the Christian sects then represented in Calcutta. For on the practical ground of economy of energy and strength of aggressiveness, as well as on the 
highest of all, he ever desired unity. He found an agency in the well-known Calcutta Missionary Conference.

Mr. William Pearce, the generous and catholic-minded son of the Rev. Samuel Pearce of Birmingham, had, as the head of the extensive Baptist Mission press, been in the habit of inviting the few Protestant missionaries to breakfast on the first Monday of every montl. The meeting was found so pleasant and profitable that it grew into a more formal conference after breakfast, with devotional exercises before that meal, according to the early hours and pleasant hospitality of Indian life. The nomination of a secretary, to take notes of the papers and conversations, further gave the gathering that permanence and utility which it has enjoyed now for half a century. To this body Mr. Duff submitted his plan of a united college, such as has recently been carried out in Madras for all Southern India and is still under discussion for Bombay. For a fee of ten shillings a month Mr. Duff declared his willingness to receive the best vernacular pupils of the various missinns and give them the highest Christian education. All approved, and the Conference appointed a committee to work out the plan in detail. But, as has often happened since, the divisions of the Western Church were fatal to the growth of that of India. Mr. Duff prepared the plans of a building which would accommodate the students below, and at least two other colleagues, lay or clerical, above. This scheme showed a mastery of detail and a foresight such as would have anticipated the various colleges, comparatively weaker, which the missionary societies were afterwards compelled to erect and which they still conduct.

We survey with pain the outlines of so stately, so Christlike a prospect for the Christianizing and civilizing of the millions of our subjects in Bengal, when wo 
reflect that what was easy in 1832 has still to be attempted; and why? Because the outburst of what is in itself a miserable church and state controversy, however important to the actual combatants, made it impossible for the Nonconformist Churches to work along with the two Established Churches of Scotland and England in carrying out the last command of their common Lord, although their missionaries in the front of the battle were unanimous in the desire for such co-operating unity. As Charles Grant's farseeing proposals of 1792 fell to be made facts unconsciously by Duff in 1830-33, so Duff's have yet to be realized, in Northern and Eastern India, by the divided Churches of the West.

Rarely if ever in the history of any portion of the Church at any time since apostolic work ceased with John the Divine, has one man been enabled to effect such a revolution in opinion and to sow the seeds of such a reformation in faith and life, as was effected by the first missionary of the Scottish Church in Bengal in the three years ending July, 1833. In the form of an experiment as to the suhordination of education to evangelical religion, Duff's work was watched, criticised and narrowly weighed, not only by benevolent men but by officials of all kinds throughout India. Towards the end of 1831 , from the then very distant Bombay there came to Calcutta, to study and report upon it, Mr. Henry Young, of the civil service of Western India. He was a friendly supporter of the Rev. John Wilson there, who gave him a letter of introduction to Mr. Duff. Let us obtain a few glimpses of the state of native society in Calcutta in the sixteenth month after the opening of the General Assembly's school, as given by a broad-minded layman of great administrative experience as well as Christian benevolence. 
"November 15th, $18 \% 1$.

"Dear Mr. Wilson, - . . I availed myself on landing of your letter to Mr. Duff, and lived with him during the time I spent in Calcutta. I have never regretted doing so, as it has afforded me an opportunity of seeing much and learning nore regarding a class of young men who, of all others, engaged my attention in that place; and I am sure you would not fail to share in the common interest felt, were you to witness the pleasing progress they are making under Mr. Duff. The nunber of young men who, having received a college education, have really thrown off idolatry, is very great; but there are not above eight or nine who come boldly forward, and brave every effect of the pride and bigotry of their countrymen. Of these Krishna Mohun Banerjea, the editor of the Enquirer, is the most conspicuous. He certainly leads the rest, and, by the admission of all, is the most sober and well conducted of the whole. In a conversation I had with him the day before I left, he told $m e$ there were not more than four upon whom he could depend for decided support, and who go the full !ength of his own principles; but he thinks the rest are coming round, and upon them he hopes principally to exert an influence by means of his paper. It must be remembered that they were formerly bold, impetuous characters, puffed up with conceit of their supposed attainments, and forward in proclaiming their atheistical sentiments. Now they profess a belief in the Supreme Being, and speak in the very best tone, and maintain their desire to judge nothing rashly. They will not, they say, hesitate to condeunn and to expose idolatry and the Brahmanical impostures, because they are convinced of the folly and absurdity of their furmer belief; but of Christianity they will examine and inquire, and are ready to embrace the truth wherever and whenever they see it.

"There can be no doubt that, under God, they are indehted for this favourable change to Mr. Duff's lectures, and to the knowledge they have acquired of English. All the direct effects of their education at the Hindoo College have been, with this exception, decidedly evil; and though it has been overruled in this instauce, as far as we can see, to the furtherance of good, jet it is only the direct effects of that system to which its directors can lay claim. Mr. Duff has a school of about 151 
boys, in which there are some of the higher class that can now read and write with some fluency in English. When they are a little farther advanced Mr. Duff will gradually instruct them in the higher branches of science and literature, and ground then thoroughly in the evidences of religion, and go over every objection that the iufidel has made to them, with a view of preparing them for a successful resistance to those young men whom the college is daily sending forth with heads filled with the subtleties of Hume, etc. So that his two objects at present are (and between these he divides his time): to put himself at the head of the movement already taken place amongst the students, and gradually reclaim them from the wrong paths they have taken; and to train up another set of young men who have not been subject to the disadvantages these have felt, who have not lost the docility and teachableness so necessary in receiving the truth, and who, if God vouchsafe His blessing, may furnish a body of well educated young men of a far superior order to any that we have yet seen in India. This was the proper object of Bishop's College, and it has failed from causes which are well known, and which are fatal to the success of every human scheme. Mr. Duff is, in fact, about to establish an Institute himself, the plan of which has been fully arranged, and has met with the concurrence of all here, and which only wants the sanction of the home authorities to be at once set on foot. In the meantime this school forms a nucleus, and has arisen unostentatiously without exciting any great notice, and will ultimately furnish him with a set of students to commence with who have been brought up under his own eye and under his own system, which, I might say, is a most efficient one. I questioned him a good deal about the prospect he had of securing their attendance for the period that it would require to go through his course. He said he felt, as all others feel, how difficult it was, but that such was the eagerness of the boys to remain, that if they could only obtain a sum sufficient for their support, they would resist every inducement held out by their families to leave him; and that, in fact, he had resolved in all cases of difficulty to supply them with funds hiuself, and he accordingly does so support one or two of them already. He said six or eight rupees a month was ample, aud that he himself only gave them four. The same practice was found necessarg 
at the Hindoo College, and some boys in the first class now receive from Government fifteen rupees a month ; and after all that can be said against the measure, I am fully persuaded of its propriety, and hope that every one will support tho system.

"I very soon, of course, came to ask his opinion upon the subject of education generally, and stated our circumstances to him. He attributed the ill success of scriptural education to the imperfect and elementary nature of the education given and the neglect of the English language, and seemed to have the fullest conviction of the success of the system he is abont to pursue ; for to every suggestion about the inutility and ill success of schools, he always replied that he thought the failure was owing to the not communicating a medium through which sound and enlarged ideas respecting God and our relations to Hin might be conveyed, and through which the effects of what education they did receive might be kept alive and strengthened. After what I witnessed of the facility of English instruction, I could not urge as an objection the difficulty of imparting it, and, in short, I came away from Calcutta fully convinced that in neglecting English we have neglected the most efficient instrument we could have used. With all the young men I have spoken to you about, any person may have the most free and unreserved communication in our own language; and it quite astonished me to find how closely and attentively they followed Mr. Duff in the most abstract and metaphysical discussions, taking up the weaker parts of an argument with a readiness which showed how fully they had conprehended what was addressed to them. I do not mean that their objections were always the happiest, but they showed they had, in the main, comprehended his arguments. He fully concurred in all we proposed to do, though 1 cannot say he went the length which I have hitherto been disposed to go, in asserting unreservedly that knowledge without religion is positively evil.

" Mr. Duff's school has not been in operation sixteen months, and yet an advance has been made sufficient to extort the praise of Mr. Hare, who told me, as he was showing me the college the other day, that Mr. Duff deserved credit for it. Let us hear no more, therefore, of the difficulty of teaching them English. I have seen it here in various instances effectually surmounted. The Hindoo College is a fine quadrangular build- 
ing, the inner area being very small, so as to give the house the shape of a native building; I do not say appearance, for it is built after a regular Grecian order, and, like most houses in Calcutta, is very handsome and elegant. The ground-floor students are exclusively engaged in the study of Sanscrit, which occupies them seven or eight years, and one cannot belp grieving at the sad and cruel waste of precious time and talent at this unprofitable study. English has been introduced recently, that is to say, since the last two or three years; and I observed one class going over a proposition of Euclid, which they seemed to enter into con amore. 'The first class had just returned from a lecture on some branch of natural philosophy, and seeing some essays of their composing I asked for oue or two, which with some hesitation they granted. I was surprised to find on my return that one went directly to refute Paley, and establish the mortality of the soul and the futility of any hopes as to futurity. The subject was: 'Is Paley's definition of virtue, viz., that it is doing good to mankind for the sake of everlasting happiness, correct?' and the writer contended that after death the soul vanished into thin air, etc.

"I was fortunate enough to witness, on the Tuesday before I sailed, a missionary prayer meeting. 'There were present (at Mr. Duff's in rotation), Mr. Duff, W. H. Pearce, Yates, Sandys, Percival, Mackay, Christie, G. Pearce, T. Robertson (chaplain), Reichardt, Lacroix, Gogerly, and two or three others whom I cannot recollect. At seven we met upstairs and engaged in prayer uutil breakfast-time, when about twenty sat down. After breakfast subjects that had been proposed at the last meeting for discussion were announced, and the sentiments of each person present were called for. The question under discussion was, as far as I recollect it, ' the relative importance of itinerant preaching as compared with education, as a meaus of spreading the gospel,' and the sense of the meeting was expressed in the three resolutions I alluded to in my letter to Robert Money. The subject was very well, as I thought, discussed, but not exhausted; and I should like to have proposed for inquiry next month, "The origin aud recorded success of juvenile education as a means of spreading the gospel in heathen countries.' The question, however, proposed by Mr. Mackay will perhaps embrace this. There was at least a proportion of two-thirds of the meeting present who were engaged 
directly in itinerant preaching in, around, or away from Calcutta. Mr. Lacroix is said to be by far the most ready and effective preacher, and to draw crowded audiences.

"The infant school, under Mr. Macpherson's superintendence, founded by the Bishop and conducted by a Mrs. Wilson, flourishes; so, I believe, does the High School, under the Rev. Mr. Macqueen, who is rector; but the Free School of St. James's parish is wretchedly organized, and the children are almost parrots. I wonder any person neglects to introduce the interrogatory system of instruction; no other deserves, I think, support. I must not omit to say that the day before I left, Tarachund Chukurbutee, the leader of the Moderates (as they are called who, renouncing idolatry, yet fall short of the decision and uncompromising spirit of Banerjea and others), called upon Mr. Duff and promised to attend with several of his friends at Mr. Duff's lectures. This was a subject of great delight to us all, as they had hitherto declined to mix with the Ultras (as they are styled), and feared to compromise their worldly interests."

Three months after Mr. Young's visit we find Mr. Duff's own humble estimate of the results, but farreaching statement of an unconquerable faith, in two letters to the Rev. Professor Ferrie, of Kilconquhar :-

\section{"Calcutta, 9th January, 1832.}

"Here there is little change: much work of preparation silently carried on, little of the practical work of conversion from dumb idols to serve the living God. We cannot overestimate the worth of an immortal soul, and should one be found cleaving to the Saviour steadfastly and immovably we cannot rejoice too much or ascribe too much glory to God. But methinks that, considering the millions still nnreclaimed, our joy should be tempered and our glorying moderated, lest the one should be found to be mere selfgratulation and the other a vain boastfulness. How I fear that much, far too much, has been made of partial success in the work of conversion, and that many good people at home are under serious delusion as to its extent. Everything around me proves the necessity of more earnest prayer 
and redoubled exertion. I see nothing to satisfy me that any decisive victory has been won on the grand scale of national emancipation. The few converts that have been made can never be the seed of the Church : they resemble rather those somewhat unseasonable, somewhat short-lived germs which start up under the influence of a few peculiarly genial days in winter-an indication of the semiual power of mother earth, and a token of what may be expected in spring. Let us not then confine our views to the few shrivelled sprouts of a mild winter ; - for these let us be thankful, as they tend to revive our hopes and reanimate our sinking spirits. But let us reach forward with restless longing and unceasing effort to the full glow and life and verdure of spring, when the whole earth shall be loosened from its cold torpor and the heavens pour down refreshing floods. It is not easy in Calcutta to congregate a decent audience to listen to Bengalee preaching. The people are naturally apathetic, and here there is superadded such pervading avarice, such money-making selfishness, that it is difficult to secure any degree of attention, or even to excite any alarm for the safety of their own religion. Thousands there are, in fact, who cannot be said to have any religion at all. Preaching generally becomes either a conversation, or a discussion in which the most arrant frivolities in argument are reiterated with an obstinacy that wastes precious time, and wholly impedes the free deliverance of truths that might quicken the conscience and save the soul alive. More, generally speaking, can be done by way of direct preaching in Bengalee in the neighbourhood than in the town of Calcutta, though I think that missionaries have often too readily given way to the accumulation of acknowledged difficulties to be encountered in town. To desert it is like abandoning one of the enemy's strongest holds and allowing him to occupy it undisturbed.

"My labours in Bengalee preaching have hitherto been necessarily very limited. But there is a sphere now partially occupied, formerly alnost nnattempted : there is the instituting of English schools under a decidedly Christian management, and insisting on the inculcation of Christian truths. 'The field may become one of the richest in bearing luxuriant fruits. We only want the necessary funds and qualified agents. The success that has attended the large school first established has 
infused a kind of new stimulus into the minds of those most interested in the Christian education of the natives, and in that alone much real good has been achieved. The work is excessively laborious and not a little expensive, but time will show its vast importance. I trust that you are acquainted with the various proposals already forwarded to the Assembly's committee. I crave your special attention to the last, as being perhaps one of the most momentous that has ever been forwarded from a heathen land, referring chiefly to a union of all denominations in the support of a Central Institution for the more advanced literary and religious education of promising native youth; and to be under the exclusive control of the Assembly's committee. I refer you again to the printed proposals sent home, and expect your powerful advocacy of the measure.

"Thousands can now talk English tolerably well. Amongst these I labour a good deal, as this class, being of the better sort, has generally been neglected. For the last two or three months I have been delivering a course of lectures on the evidences of natural and revealed religion, to about fifty of the more advanced young men who have been educated at the Hindoo College, as well as of the class of Last Indians who have received a competent education. On the whole the effect is pleasing. Much discussion takes place at times, but in the end objections have hitherto been withdrawn.

"Our church still droops. Were an acceptable preacher to officiate regularly it might yet be in some degree recovered from its degradation. I preach occasionally, and perceive clearly that many are willing to attend, and under a different state of things would, but refuse at present on the presentation of a plea which they hold to be sufficient. Consequently many have joined other communions permauentl 5 , many temporarily, and many live without the stated administration of ordinances. In this way that which once was a united community is now severed into fragments; and that aid which would once have been and now might be afforded can no longer be expected. Oh let us have a pious and talented successor to Dr. Brown, and much may jet be done. Another of the same stamp when the present incumbent retires, and a vast deal may be done towards restoring our Zion. Such appointments would immensely profit the Assembly's Mission. Mr. Mackay, if he enjoy good health, 
will do well. But he does not appear to be strong, nor capable of undergoing much bodily fatigue, nor exertion in speech, all of which is so essential to the active discharge of a missionary's duties. I wish the committee would bear in mind that a constitutional vigour of body is just as requisite as a vigorous activity of mind, and piety and learning. Indeed it is not studying men that we want, but hard-working men who have been and still are students."

"Feb., 1834.-Awakened by the pleasing success which has attended our humble efforts in Calcutta, some zealous friends at home, as I hear, are beginning to think that a new station might be opened. Now, let me say at once that nothing would prove more disastrous. Of all stations in India Calcutta is by far the most important. Its population is a vast motley assemblage or congregation of persons from all parts of Eastern Asia. Of course the natives of Bengal greatly predominate, and next to these, immigrants from all the provinces of Gangetic India. A revolution of opinion here would be felt more or less throughout the Eastern world, and particularly among the millions that are the victims of idolatrous delusion and Brahmanical tyranny. It is of no ordinary importance, therefore, to make Calcutta the grand central station for conducting missionary operations on an extended scale. But we require a score more labourers, and if we had two scoro Calcutta alone and its neighbourhood would afford abundant scope for thcir best efforts for at least several years to come. It has hitherto been a radical error in the organization of missions, to scatter the pioneers and so dilute and fritter away their strength, instead of concentrating their efforts on some well-chosen field. I sincerely trust that this is an error which the committee of Assembly will endeavour to avoid, and that all their aim will be for years directed towards the strengthening of the Calcutta station.

"I perceive it was stated in the last Assembly by $\mathrm{Mr}$. Thomson, of Perth, that the Assembly's Institution should always remain a mere school. No remark has astounded me more for many a year-the utter ignorance which it betrays of the wants of this people and the most probable means of supplying these with success! If it is to continue a mere school, then I say that all the time, monoy and labour hitherto expended on it have been thrown away for nought. Instead 
of being an apparatus which frod might bless as the means of leading heathens to the way of salvation through Christ, it would be much more likely to become a machine for transforming superstitious idolaters into rogues and infidels. It has been entirely overlooked that in this country there is a gigantic system of error to be rejected ere a system of truth can be embraced; and the few years which a boy can spend at a mere school can barely suffice to open his mind to the absurdity and irrationality of the religion of his ancestors, a religion that closely intertwines itself with every feeling and faculty of the soul, with every habit and every action of life. But supposing that in a mere school you could succeed in overthrowing Hindooism and in inculcating much of the knowledge of Christianity, still if the boy be not confirmed in any belief, and you turn him adrift amid a multitude of heathens the most licentious and depraved under the sun, what must be the consequence? I can only say from experience, that his latter end must be in all respects worse than the first.

"Our only encouragement is the hope of being able to induce a certain proportion of those who enter as boys to remain with us till they reach the age of puberty, and consequently, attain that maturity of judgment which may render kuowledge, through God's blcssing, operative and impressions lasting. And were there no reasonable hope of securing this end, I would without hesitation say, 'the sooner you abandon the school, the better.' I, for one, could not lend myself as an instrument in wasting the funds of the benevolent in Scotland in teaching young men a mere smattering of knowledge, to enable them to become more mischievous pests to society than they would have been in a state of absolute heathenism. On the other hand, if out of every ten that enter the school even one were to advance to the higher branches of secular and Christian education; were he to become in liead and in heart a disciple of the Lord Jesus; and were a number with minds thus disciplined, enlarged, and sanctified, to go forth from the Institution, what a leaven would be infused through the dense mass of the votaries of Hindooism! And what a rich and ample reward for all one's labours, what a glorious return for all the money expended! I look to you, my dear sir, as one whose superior discernment can penetrate 
this subject, and expose the erroneous views of snch zealous but, in this instance, mistaken men as Mr. Thomson of Perth.

"The school continues greatly to flourish. You may form some notion of what has been done, when I state that the highest class read and understand any English book with the greatest ease; write and speak English with tolerable fluency; have finished a course of geography and ancient history; have studied the greater part of the New Testament and portions of the Old; have mastered the evidence from prophecy and miracles; have, in addition, gone through the common rules of algebra, three books of Euclid, plane trigonometry and logarithms. And I venture to say that, on all these subjects, the youths that compose the first class would stand no unequal comparison with youths of the same standing in any seminary in Scotland. Other labours progress apace. My Tuesday evening lectures on the evidences and doctrines of Christianity are still continued. God has been pleased to bless them for the conversion of a few, and the obstinacy of many minds has been shaken. On Sinday evening I preach also in English to considerable numbers in a small native chapel. There is cercainly much to encourage, while there is much also to damp one's zeal. Believe me, the people at home have far too exalted an idea of what has been done in India. Still, much has been done; and that draws out the hope of soon doing still more. Let us not rest till the whole of India be the Lord's."

In all this warfare of the young apostle against the hoary citadel of Brahmanism, and in the retreat of the foremost of its men into the slough of theoretical atheism and practical immorality, or of vague theism and a dead ethics, we have seen the divine influence at work. To Calcutta and Bengal, as once to Jerusalem and Syria, Christ was being manifested to destroy the works of the devil. We must now look more closely at the human instrument He had chosen through which to pronounce the wonder-working spell, not only in the native city and for that generation, but over all India and Southern Asia and for the ages to come. It was the Greek tongue and the 
Et. 27.

Roman order in that which was to all the race the fulness of the ages. In India the set time came with the English language, with the legislation and the administration, the commerce and the civilization of the British people. The Missionary had, thus far, done his work. The Governor-General in Council must now do his. 


\section{CHAPTER VII.}

$1833-1835$.

\section{THE RENAISSANOE IN INDIA-THE ENGLISE LANGUAGE AND THE CHUROH.}

Lord William Bentinck ready.-The Charter of 1833.-Macaulay's share in that and in the Reform Act.-His Contrast of Calcutta and Edinbargh.-Sir Charles Trevelyan becomes his Brother-inLaw.-Trevelyan's Alliance with Duff.-The Growth of a Vicious Orientalism after Lord Wellesley.-Lord Minto.-Bishop Heber. -The Prinseps and W. H. Macnaghten.-The Anglicists.-Mr. B. H. Hodgson and the Vernacularists.-Duff's Experience as a Celtic Highlander.-James Mill.-Macaulay's Famous Minute.The Missionary's Greatest Ally.-Decree of Lord William Bentinck's Government.-Sir C. Trevelyan's Account of Duff's Trinmph.-Duff's Modest Narrative.-His Regard for True Oriental Scholarship.-Vindicates the Government Decree.Shows where, from political expediency, it failed.-Eloquent Application to the Chnrch of Canning's Peroration on the New World.-Macaulay's Revival of Letters and Duff's Indian Reformation begun.

LoRd WIILiam Bentinck was ready. He had enjoyed what some call the drawbacks, but all true men pronounce to be the real advantage, of being a younger son. The second son of the third Duke of Portland, Lord William Cavendish Bentinck was thrust out into positions where he developed for the good of humanity all those virtues and that ability which had made Hans William, the founder of the house, second only to his friend William III. as a benefactor of Great Britain. Because, while still under thirty, he happened to be Governor of Madras when the family of Tippoo provoked the mutiny of Vellore, Lord William 
Bentinck was recalled by the Court of Directors for oxacly the same avowed reason which caused their own extinction after the Mutiny of 1857. In the interval before his return to India as Governor-General the young administrator secured a constitution for Sicily, and, in 1814, he would have restored the old republic of Genoa but for Lord Castlereagh's stupidity. It was one of the many merits of George Canning that, during his too brief term, as Prime Minister, he sent Lord William Bentinck to govern all India. Already, when Duff landed, had the new Governor-General spent two of the seven years which have marked the page of British India with triumphs hardly less brilliant than those of the Marquis Wellesley, and paralleled only by the later achievements of the Marquis of Dalhousie. Had he, as he wished, been appointed the immediate successor of Lord Hastings, instead of the weak Amberst, it is difficult to decide whether he would have prepared the way for Duff's mission of positive Christian truth and educational progress, or whether his lofty benevolence would not have failed, like other premature ideals, for want of the concurring aids of a ready man and a ripe time. As it was, it was well that the purely educational, literary and scientific reforms of his Government fell at the end of his seven years' career in the highest office which any man can fill next to that of Premier of the United Kingdom.

It was well also that to the work of Duff and the legislative and administrative measures of Bentinck, applying the principles and results of that work to all India and for all time, there were added the indispensable co-operation and the supreme sanction of the British people through Parliament. For the first fruit of the Reform Act of 1832 was the East India Company's charter of 1833 . That charter withdrew 
the last obstructions to the work of Duff and of every settler in India, missionary or journalist, merchant or planter, teacher or captain of labour in any form. It converted the Company into a purely governing body, under a despotic but most benevolent constitution so well fitted for the freedom and the eleration of longoppressed races that the most democratic of English thinkers, Mr. John Stuart Mill, has declared the system to be the best ever devised. That charter has the additional merit of giving men, as well as rendering possible a constitutional system, to India. It added a law member to the Governor-General's council or cabinet, then of five, and created a commission to prepare codes of law and procedure such as have come next only to Christianity itself, from which they spring, in their humanising and elevating influence. To mention no others, these four men, Lord Macaulay, Sir Barnes Peacock, Sir Henry S. Maine and Sir James F. Stephen have together done more for the raried races and the corrupting civilizations of the peoples of India than the jurists of Theodosius and Justinian effected for Europe, or the Code Napoléon for modern France.

The eloquence of the young Macaulay in carrying the Reform Act resulted in his appointment as one of the commissioners, and then as the secretary, under Lord Glenelg and along with Sir Robert Grant, of the Board of Control. He was the master of the Court of Directors for eighteen months, and they for some time opposed his nomination as the new law member. Was not the charter of 1833 his doing, and was he not, at thirty-three, in their eyes an intolerably conceited person? Six years older than his countryman and fellow Highlander, of whose doings he could not help being officially cognisant, little did he think that without himself the revival of letters and of faith, 
brought to the birth by the young missionary, could not be perfected. So it is that God works by many and apparently incompatible instruments. For Macaulay was ever the apostle of the old Whig neutrality in religion, whether in India or in Ireland, although his whole boyhood had been steeped in the discussions of his father, of the Clapham men and Hannah More on the evangelization of the Hindoo and the Negro alike.

It was not till June, 1834, that Macaulay reached Madras to join the Governor-General, then at the Neelgherry hills, while he sent his sister on to Calcutta, there to be the guest of Lady William Bentinck. Duff had just left India stricken down by almost deadly disease as we shall see, when in sultry September the Honourable the Law Member of Council took up his abode, under a salute of fifteen guns, in what is still the best of the Chowringhee palaces, the Bengal Club. But none the less, Macaulay's greatest work-greater than even his penal code and his Warren Hastings and Clive essays-was to be the legislative completion of the young Scottish missionary's policy. Yet Macaulay was never happy during his brief Indian residence of three and half years. He did not know the magnitude, he had not his father's faith to realize the consequences, of the educational work between which and a re-reading of nearly all the best Greek and Latin authors he divided his leisure. In 1854, when Sir Barnes Peacock completed his penal code, Macaulay wrote to his sister, " Had this justice been done sixteen years ago I should probably have given much more attention to legislation and much less to literature than I have done. I do not know that I should have been either happier or more useful than I have been." And in the glorious cold season of Bengal, so carly as December, 1834, he had thus sighed out his "heimweh" to Mr. Macvey Napier, of Edinburgh : "Calcutta 
is called, and not without some reason, 'the city of palaces;' but I have seen nothing in the East like the view from the Castle Rock, nor expect to see anything like it till we stand there together again."

There was a third official, the warm personal zeal of whose co-operation drew him closer to Duff than the two rulers, without whom his energizings could not have been either so abiding or so imperial in their consequences-Charles Trevelyan. Like Sir Henry Durand at a later date, he had been compelled by public duty to report to Government the malversation of a high civilian, an offence happily rare since Clive's reforms. But Macaulay himself tells the story :-

"Trevelyan is almost eight-and-twenty. He was educated at the Charterhouse, and then went to Haileybury, and came out hither. In this country he has distinguished himself beyond any man of his standing, by his great talent for business; by his liberal and enlarged views of policy; and by literary merit, which, for his opportunities, is considerable. He was at first placed at Delbi under — , a very powerful and a very popular man, but extremely corrupt. This man tried to initiate Trevelyan in his own infamous practices. But the young fellow's spirit was too noble for such things. When only twenty-one years of age he publicly accused —, then almost at the head of the service, of receiving bribes from the natives. A perfect storm was raised against the accuser. $\mathrm{He}$ was almost everywhere abused and very generally cut. But, with a firmness and ability scarcely ever seen in any man so young, he brought his proofs forward, and after an inquiry of some weeks fully made out his case. — was dismissed in disgrace, and is now living obscurely in England. The Government here and the directors at home applauded Trevelyan in the highest terms, and from that time he has been considered as a man likely to rise to the very top of the service.

"Trevelyan is a most stormy reformer. Lord William said to me, before any one had observed his attentions to Nancy: 'That 
man is almost always on the right side in every question; and it is well that it is so, for he gives a most confounded deal of trouble when he happens to take the wrong one.' He is quite at the head of that active party, among the younger servants of the Company, who take the side of improvement. In particular, he is the soul of every scheme for diffusing education among the natives of this country. His reading has been very confined; but to the little that he has read he has brought a mind as active and restless as Lord Brougham's, and much more judicious and honest. - . He has no sinall talk. His mind is full of schemes of moral and political improvement, and his zeal boils over in his talk. His topics, even in courtship, are steam navigation, the education of the natives, the equalization of the sugar duties, the substitution of the Roman for the Arabic alphabet in the oriental languages."*

Trevelyan had not been a week in Calcutta when, in 1831, he threw himself into the different movernents originated by Duff. In their first interview the two young men soon found themselves absorbed in this question of all others - the advantage, the positive necessity of using the English language as the medium of all Christianizing and civilizing, all high educational and administrative efforts by its rulers to reach the natural aristocracy and leaders of the people, and through them to feed the vernaculars and raise the masses. Duff's plans, his experience, his success, were not only accomplished facts, but had been then for twelve months the talk and the imitation of every thoughtful and benevolent Englishman in the far East. Trevelyan told how he himself, at Delhi, had been for four years speculating on the advantages of thus using the English language. From that hour he clung to the missionary, and became the principal link between his far-seeing practical principles on the one hand and

The Life and Letters of Lord Macaulay, by his nephew, George Otto Trevelyan, M.P. Second Edition, vol. i., p. 387. 
the coming action of Government in the same direction. It fell to Macaulay to advise and to the Governor-General to act under the following circumstances.

When the British succeeded to the Muhammadan civil government of Bengal and Hindostan, on the Emperor Shah Alum's grants to Clive at Benares in 1765, Warren Hastings made the first and most enlightened attempt to popularise the sacred books of Islam and Brahmanism by Halhed's translations. It was in vain. When Lord Cornwallis was forced to put the judicial as well as revenue courts under British officers, he still made a barbarous Persian, as technical as the language of the Scottish courts, the only lingual medium between the people and their new rulers. The earliest colleges, as we have seen, Muhammadan at Calcutta and Sanscrit at Benares, were created to prepare the few natives required as intermediaries between the Company's civilians and their subjects. Thus an orientalism unworthy of the name of scholarship sprang up, grew by tradition in spite of English scholars like Sir William Jones, and widened the gulf between the foreign ruler and the ignorant, oppressed and suspicious ruled. Lord Wellesley was the first who had the genius to seek to correct the evil. In spite of the parsimonious Court of Directors, he established the College of Fort William. He put Carey and Buchanan practically at its head, to teach the vernacular as well as classical languages of the East, and to train the young "writers" with a view, as Duff described it, to "the formation of sound moral and religious habits, as much as for the cultivation of all branches of professional or useful knowledge." That college, like "the glorious little man" its founder, sent forth a body of scholars and administrators to whom we orve the conquest and good government of India up to the next generation of their pupils, headed 
Et. 28. THE GROWTH OF A VICLOUS ORIENTALISM. 185

by the Lawrences and Durand, Thomason and the Muirs. Some, like Lord Metcalfe, early corrected the orientalizing tendency of their studies by executive work on the widest scale. Others, like Sir W. Macnaghten, intensified its evils by the narrowing work of a mere secretary to Government. Lord Minto's administration, more brilliant in some respects than has yet been allowed, identified the growing orientalism, not with the toleration in which it was born, but with antichristian anti-popular timidity. Lord Hastings, though personally friendly to the religious instruction of the natives, found the oriental mania in this form too strong for him to let it grow. Sydney Smith's brother, who had made a fortune as Advocate-General in Calcutta, proposed the educational clause in the charter of 1813, doubtless in the interest of the Brahmanizing orientalists, who bad almost unchecked influence with the Governor-General when it came to be applied. But whatever the intention, Parliament, led by the Grants and Wilberforce and deluged with petitions from the whole country, had so worded the clause as to secure the education of the whole people of India in positive truth of every kind, the revealed truth of Christianity being no doubt as much in their mind as the superstitions of Brahmanism and the Koran were in that of the minority. Like much else in human compromises, confessions and contracts, the language fortunately allowed of honest development according to the growing needs of the country and the time.

Still the orientalists, being in power on the spot, had the unchecked administration of the money allowed for public instruction. In spite of Rammohun Roy, notwithstanding the expressed desire of the natives themselves for. English, although the vernaculars were barren and the classical books printed and 
taught were not touched by one native who was not highly paid for submitting to learn them, the British Government persisted in its folly. When the expediency of spending a little of the grant ordered by Parliament on the Hindoo College established by the natives themselves was forced on the authorities, the agent whom they selected to represent them was the most intense and least Christian of all the oriental party-the assistant-surgeon, Horace Hayman Wilson. Even in 1833, when the Company had to render the next account of its stewardship, the Government Committee of Public Instruction was equally divided between Oriento-maniacs and Anglo-maniacs, as they called each other. What the teaching was in the partially English Hindoo College we have seen. It remained in the Benares Sanscrit College exactly what Bishop Heber described it to bave been during his tour in Upper India. Under a grant ordered by Parliament on the pressure of the Christian public, and administered by a Christian Government, a professor lecturing on a terrestrial globe identified Mount Meroo with the North Pole, declared that the tortoise of the Hindoo cosmogony supported the earth from under the South Pole, pointed to Padalon in the centre of the globe, and demonstrated how the sun went round the earth every day and risited the signs of the Zodiac! Well might the teaching of such " rubbish" in a state college excite the wonder of the Bishop. But that was harmless compared with what was taught elsewhere, and even with the obscenely idolatrous teaching which lingered in Government school-books till Lord Northbrook purged them three years ago, if indeed they be yet purged.

When Trevelyan came to the support of Duff, and adopted his plans as well as his principles as the only policy for Government, the Brahmanizing five in the 
Government committee were these: The Honble. H. Shakespear was a colleague of the Governor-General, and only as such was dangerous. Mr. H. Thoby Prin. sep and Mr. James Prinsep were brothers. The latter, an uncovenanted officer of the Mint, was the greatly lamented scholar who fell an early victim to his too eager researches into the inscriptions on coins and rocks which he deciphered. The former was one of the under-secretaries to Government at that time, was a greater scholar in Arabic and Persian than his brother, was afterwards director, member of Parliament, and member of the Secretary of State's council, and died at eighty-six, the day before Duff. William Hay Macnaghten was a Charterhouse boy, who from the day he landed in India, first as a cadet and then as a civilian, mastered the several languages of south and north, proved the most extraordinary scholar in the classical tongues ever turned out by Fort William College, and was trusted by Lord William Bentinck beyond any other secretary. His evil policy and sad fate in Cabul make his career most tragic. These, with the zealous secretary of the committee, Mr. T. C. C. Sutherland, made the orientalists very formidable antagonists.

The Anglicists were no less strong, however. Foremost among them was the greatest land-revenue authority, Robert Mertins Bird, who corrected and completed the work of Holt Mackenzie, author of the first official minute on education, and at whose feet Lord Lawrence sat as a revering pupil. Mr. J. B. Colvin was he who died in Agra Fort during the mutiny, Lieutenant-Governor. Sir Charles Trevelyan atoned for the probably routine efficiency of Messrs. Saunders and Bushby, who always voted straight. We must in justice to these two main parties add a third, whom we may describe as Vernacularists. Allying himself with the Serampore men then left, with Dr. Marsbman and 
his son in the Friend of India, Mr. Brian H. Hodgson, long the first authority on Tibetan Buddhism, advocated the foundation of a normal vernacular institution to manufacture good teachers, reliable translators and pure books. English, he urged, would be as bad as Persian, Arabic and Sanscrit, which had "proved the curse" of India, "not so much by reason of the false doctrines they have inculcated as by reason of the administrative mystery they have created and upheld."

All that was good, or possible at the time, in $\mathrm{Mr}$. Hodgson's then really remarkable proposal Mr. Duff had already advocated or actually carried into effect. His school and college long proved to be the first of normal training institutions in India, which, indeed, has had no others worthy of the name save those established by the Christian Vernacular Education Society since the mutiny. The vernacular department of his school, fitting into the English and ultimately the Sanscrit classes, secured all that the great orientalist of Nipal wanted. But Hodgson, in common with his less enlightened fellows on the committee, could not see that while the natives themselves desired English, while it was administratively necessary as well as politically desirable to give them facilities for mastering the English literature as well as language, no body of truth, scientifi, historical or ethical, not to say Christian, could be conveyed to the natives through their then barren vernaculars or sealed classical tongues. The Government, like the missionaries, must begin at both ends : at the vernacular that the people might at least read and write their own language intelligently, and at the higher or English end that thence their own teachers might convey the material and even the terms of truth to them through the vernacular ; and in time to the learned through the Sanscrit, Arabic and Persian. Writing of this period Duff declared:- "I saw clearly and ex- 
pressed myself strongly to the effect that ultimately, in a generation or two, the Bengalee, by improvement, might become the fitting medium of European knowledge. But at that time it was but a poor language, like English before Chaucer, and had in it, neither by translation nor original composition, no works embodying any subjects of study beyond the merest elements. As a native of the Highlands I vividly realized the fact that the Gaelic language, though powerful for lyric and other poetry and also for popular address, contained no works that could possibly meet the objects of a higher and comprehensive education. Hence those who sought that found it in English colleges, and returned as teachers and preachers to distribute the treasures of knowledge acquired through English among the Gaelic people."

Just when, in 1834, Duff's success, Trevelyan's earnestness, and the increasing urgency of the despatches from the Court of Directors drafted by his friend Mr. James Mill* had produced a dead-lock in the Committee of Public Instruction, Macaulay was appointed its president. But he declined to act until the Government, of which he was a member, should have decided the question of policy in its executive capacity. And to him, as law member, the preliminary duty was assigned of declaring whether the Governor-General in Council could legally apply to English education the grant ordered by the Parliament of 1813, and hitherto reserved for a so-called orientalism. On the 2nd February, 1835, he submitted to Lord William Bentinck

- In 1836 Macanlay wrote to his father:-“" I have been a sincere mourner for Mill. He and I were on the best terms, and his services at the India House were never so much needed as at this time. I had a most kind letter from him a few weeks before I heard of his death. He has a son just come out, to whom I have shown such little attentions as are in my power." 
that minute which, while as striking a specimen of his written style as even the passage on Burke in his "Warren Hastings" pronounced by his biographer " unsurpassed," proved to be the first charter of intellectual liberty for the people of India, the educational despatch of 1854 based on Duff's evidence before a Parliamentary committee being the second.

In that minute Macaulay began by showing that the lakh of rupees set apart by order of Parliament was not only for " reviving literature in India," but also for " the introduction and promotion of a knowledge of the sciences among the inhabitants of the British territories." These words, he said, are "alone sufficient to authorize all the changes for which I contend." But so terribly was he in earnest that he proposed, if his colleagues in council differed from him, to do what would now be impossible,- - to pass a short Act rescinding that former clause of the charter of 1813 on which the orientalists based their opposition. He was himself indeed the author of the charter of 1833 more than any other man, even Lord Glenelg, and he was the most constitutional of Whigs. But, nevertheless, to propose that a local legislature, and such a legislature as that of India was till Lord Dalhousie's time, should quietly abolish an Act of Parliament, was daring even then. The proposal was unnecessary, for his opinion as the responsible legal adviser of the GovernorGeneral was sufficient. In twelve pages like this he then proceeded to prove that, being "free to employ our funds as we choose, we ought to employ them in teaching what is best worth knowing; that English is better worth knowing than Sanscrit or Arabic; that the natives are desirous to be taught English and are not desirous to be taught Sanscrit or Arabic; that neither as the languages of law nor as the languages of religion have the Sanscrit and Arabic any 
peculiar claim to our encouragement; that it is possi. ble to make natives of this country thoroughly good English scholars, and that to this end our efforts ought to be directed." Mr. Thoby Prinsep replied after the Anglo-Indian fashion, which conducts all deliberate discussion by then written and now printed minutes, often of value second only to Macaulay's, and too seldom ordered by Parliament to be published. Able as that councillor was, even in his blindness and to the last hour of his duties in the India Office, his vain representations called forth only this rejoinder, scratched in pencil, from the law member: "I remain not only unshaken but confirmed in all my opinions on the general question. I may bave committed a slight mistake or two as to details, and I may have occasionally used an epithet which might with advantage be softened down. But I do not retract the substance of a single proposition I have advanced."

Never did what his enemies called his "conceit," and hostile critics afterwards used to denounce as his "obstinacy," stand the world in better stead. He fought for the enlightenment of the millions of our Indian Empire as it then was, and of millions yet unborn. While in the same breath he officially and personally advocated religious neutrality, it was a true neutrality, intended to prevent the bostility of Hindooizing foreigners to Christian liberty and principles, and he stood forth the greatest ally the Indian missionary has ever had. It was not only English that Macaulay persuaded the Government to teach, it was the recognition of the equality of children of all castes in the public schools, from which the Brahmanizing orientalists had weakly excluded all but the Brahmans. When he fairly joined the committee he penned such ink-blotted sentences as these in the minute-book which circulated from member to mem. 
ber : "No such distinction ought to be tolerated in any school supported by us." "The general rule clearly ought to be that all classes should be treated alike, and should be suffered to intermingle freely." It was only Duff and the Christian missionaries who had up to this time disregarded caste and idolatrous festivals alike in their schools, and who had begun not only to ask but to receive fees for the secular instruction, such as the respectable poor could pay and as would make them value aright the instruction they received. But it was much that the Government should at that time follow the same just and tolerant course.

Nor was it in this only that Macaulay, as an educationist, followed Duff, through Trevelyan as the intermediary. In public instruction, as in everything else, principles are little without the men to give them effect. Even after tempting the missionary's assistants, like Mr. Clift, to leave him, Government could not get teachers worth the name. In the days before normal schools Macaulay wrote in the old minute book, "Teaching is an art to be learned by practice. I am satisfied that it will soon be found necessary to import from England, or rather from Scotland, a regular supply of masters for the Government schools." And from the first, again following Duff more or less consciously, Macaulay looked on English as the indispensable preliminary to the true education of the people in their own vernaculars. He thus supported a proposal to teach Hindee at Ajmer :- "An order to give instruction in the English language is, by necessary implication, an order to give instruction, where that instruction is required, in the vernacular language. For what is meant by teaching a boy a foreign language? Surely this, the teaching him what words in the foreign language correspond to 
certain words in his own vernacular language, the enabling him to translate from the foreign language into his own vernacular language, and vice versâ. We learn one language, our mother tongue, by noticing the correspondence between words and things. But all the languages which we afterwards study we learn by noticing the correspondence between the words in those languages and the words in our own mother tongue. The teaching the boys at Ajmer, therefore, to read and write Hindee seems to me to be bona fide a part of an English education. To teach them Persian would be to set up a rival, and, as I apprehend, a very unworthy rival to the English language."

So, just seven years before, Duff had not only written but acted in the case of Bengalee, and for the first time in the East. Before he left India Macaulay was able, sympathetically with the objects of the missionaries, to write to his father in language that reads like an extract from Duff's earlier official reports to Dr. Inglis :- "Our English schools are flourishing wonderfully. We find it difficult, indeed in some places impossible, to provide instruction for all who want it. At the single town of Hooghly fourteen hundred boys are learning English. The effect of this education on the Hindoos is prodigious. No Hindoo who has received an English education ever remains sincerely attached to his religion. Some continue to confess it as matter of policy; but many profess themselves pure deists, and some embrace Christianity. It is my firm belief that if our plans of education are followed up there will not be a single idolater among the respectable classes in Bengal thirty years hence."

Having, as a colleague of Macaulay's, endorsed his opinions in a minute, as Governor-General in Council Lord William Bentinck thus issued the decree of the 
7 th March, 1835, which fitly closed the long list of services to the people of India and his own country such as the former have immortalized by the statue with its inscription fronting the Town-hall of Calcutta, and as the latter has expressed through the eulogium penned by Macaulay:-

"1st. His Lordship in Council is of opinion that the great nhject of the British Government ought to be the promotion of European literature and science among the natives of India, and that all the funds appropriated for the purposes of education would be best employed on English education alone.

" 2 nd. But it is not the intention of his Lordship in Conncil to abolish any college or school of native learning, while the native population shall appear to be inclined to avail themselves I $f$ the advantages which it affords; and his Lordship in Council directs that all the existing professors and students at all the institutions under the superintendence of the committee shall continue to receive their stipends. But his Lordship in Council decidedly objects to the practice which has hitherto prevailed of supporting the students during the period of their education. $\mathrm{He}$ conceives that the only effects of such a system can be to give artificial encouragement to branches of learning which, in the natural course of things, would be superseded by more useful studies; and he directs that no stipend shall be given to any student that may hereafter enter at any of these institu. tions, and that when any professor of oriental learning shall vacate his situation the committee shall report to the Government the number and state of the class, in order that the Government may be able to decide upon the expediency of appointing a successor.

"3rd. It has come to the knowledge of the GovernorGeneral in Council, that a large sum has been expended by the committee on the printing of oriental works; his Lordship in Council directs that no portion of the funds shall hereafter be so employed.

" 4th. His Lordship in Council directs that all the funds which these reforms will leave at the disposal of the committee be henceforth employed in imparting to the native population a knovledge of English literature and science through the 
medium of the English language; and his Lordship in Council requests the committee to submit to Government, with all expedition, a plan for the accomplishment of this purpose."(Signed,) "H. T. Prinsep, Secretary to Government."

Rhadakant Deb and Russomoy Dutt, the native leaders of the orthodox and the liberal Bengalees, were at once added to the committee; for even the orthodox had never approved of the fanatical and, in relation to them, false orientalism of Dr. H. H. Wilson and his associates. The Prinseps, one of whom had officially signed the decree, led the Bengal Asiatic Society in an attack upon "the destructive, unjust, unpopular and impolitic resolution, not far outdone by the destruction of the Alexandrine library itself," and memorialised the Court of Directors against it. What Sir Charles Trevelyan, after all the experience of the past half-century, still thinks of Duff and his share in the triumph, that veteran reformer has enabled us thus' to learn :-

"Our concern," he writes to us, "is with the part performed by Dr. Duff at this crisis of Indian history. When he arrived in India the first marvellous results of the education given at the Hindoo College had begun to appear. Newly acquired freedom had led to a state of intellectual exaltation, and, seeing that the religious system they had been taught to venerate had no foundation, the young men jumped to the conclusion that all religion was priestcraft. Dr. Duff then came forward as a defender of the truth of Christianity, and in several public disputations he converted some and enforced respect upon all. But he did a great deal more than this. He clearly appreciated the new intellectual and moral porver which had appeared on the field, and had the sagacity to distinguish between its present abuse and the important use to which, under proper direction, it might be applied in aid of the 
Christian cause. There was a general demand for education, and he proposed to meet it by giving religious education. Up to that time preaching had been considered the orthodox regular mode of missionary action, but Dr. Duff luld that the receptive plastic minds of children might be moulded from the first according to the Christian system, to the exclusion of all heathen teaching, and that the best preaching to the rising generation which soon becomes the entire people, is the 'line upon line, precept' upon precept; here a little, and there a little,' of the schoolroom. Reconstruction upon a sound basis would then be linked with the destruction of ancient error. Whatever difficulties the Government might have, the missionary societies were free to offer religious education to all who were willing to accept it.

"The remarkable success of the school which Dr. Duff opened at Calcutta on these principles, and the influence it had in promoting the establishment of similar institutions in other parts of India, are well known, but account should also be taken of the direct access thus gained to the future leaders of the people, and of the new respect paid to missionaries as tutors of young native chiefs and other highly considered persons. These were great and pregnant reforms, which must alway's give Dr. Duff a high place among the benefactors of mankind. The indirect influence of his exertions upon the action of the Government was at least equally important. The example of his success, and the stimulus given by him to the popular demand for English education, entered largely into the causes which brought about the Resolution of Government of the seventh of March, 1835."

Duff's own attitude and criticism of the last act of Lord William Bentinck will be found in that which is, historically, the most important of his many pamphlets, 
his "New Era of the English Language and English Literature in India." With the culture that had marked his whole school and university studies, he recognised the attractions of a genuine oriental scholarship, and reproached his countrymen for their indifference to it, for "persevering in a truly barbarous ignorauce of one of the most remarkable nations and countries on the face of the globe." Following that remark of a contemporary historian, Duff continued :-

"If poetry and romance and chivalry be an object of pursuit, are there not ample stores of poetic effusion and romantic legend that might not be disclaimed as unworthy by any of the older nations of Europe ? and are the records of any state more crowded with the recital of daring adventures and deeds of heroism than the annals of Rajasthan? If philology, where can we find the match of the Sanscrit, perhaps the most copious and certainly the most elaborately refined of all languages, living or dead? If antiquities, are there not monumental remains and cavern temples scarcely less stupendous than those of Egypt? and ancient sculptures, which, if inferior in 'majesty and expression,' in richness and variety of ornamental tracery, almost rival those of Greece? If natural history, where is the mineral kingdom more exaberantly rich, the vegetable or animal more variegated, gorgeous, or gigantic? If the intellectual and moral history of man, are there not masses of subtile speculation and fantastic philosophies, and infinitely varied and unparalleled developments of every principle of action that has characterized fallen degraded humanity? If an outlet for the exercise of philanthropy, what field on the surface of the globe can be compared to Hindostan, stretching from the Indus to the Ganges, and from the Himalaya to Cape Comorin, in point of magnitude and accessibility combined, and peculiarity of claims on British Christians, the claims of not less than a hundred and thirty millions of fellow-subjects, sunk beneath a load of the most debasing superstitions, and the cruelest idolatries that ever polluted the surface of the earth, or brutalized the nature of man ?" 
Having used official documents to show the people of Great Britain and Ireland wherein the follies of the Calcutta orientalists' abuse of the public money differed from the pursuit of an enlightened scholarship, the missionary vindicated the propriety and excellence of the decree which restored the Government position of strict neutrality by allowing English to take its place beside the classical and vernacular languages of the people of India, according to their own demand, and with a view to purify the former while enriching the latter :-

"As concerns the interests and glory of the Government itself, its dissemination of its own language and literature, far from being impolitic, seems the only wise and magnanimous policy. The vast influence of language in moulding national feelings and habits, more especially if fraught with superior stores of knowledge, is too little attended to and too inadequately understood. In this respect we are in the rear of uations some of which we are apt to despise as semi-barbarous. When the Romans conquered a province they forthwith set themselves to the task of 'Romanizing' it; that is, they strove to create a taste for their own more refined language and literature, and thereby aimed at turning the song and the romance and the history - the thought and the feeling and fancy, of the subjugated people, into Roman channels, which fed and aug. mented Romish interests. And has Rome not succeeded? Has she not saturated every vernacular dialect with which she came in contact with terms copiously drawn from her own? Has she not thus perpetuated for ages after her sceptre moulders in the dust the magic influence of her character and name? Has she not stamped the impress of her own genius on the literature and the laws of almost every European kingdom, with a fixedness that has remained unchanged up to the present hour?

"And who can tell to what extent the strength and perpe. taity of the Arabic domination is indebted to the Caliph Walid, who issued the celebrated decree that the language of the Koran should be 'the universal language of the Muhammadan 
world, so that, from the Indian Archipelago to Portugal, it actually became the langnage of religion, of literature, of government and generally of common life?"

"And who can estimate the extent of influence exerted in India by the famous edict of Akbar, the greatest and the wisest far of the sovereigns of the House of 'Timur? Of this edict an authority already quoted thus wrote, about six years aro: - The great Akbar established the Persian language as tho language of business and of polite literature throughout his extensive dominions, and the popular tongue naturally became deeply impregnated with it. The literature and the language of the country thus became identified with the genius of his dynasty; and this has tended more than anything else to produce a kind of intuitive veneration for the fannily, which has long survived even the destruction of their power; and this feeling will continue to exist until we substitute the English language for the Persian, which will dissolve the spell, and direct the ideas and the sympathies of the natives towards their present rulers.' The 'until,' which only six year's ago pointed so doubtfully to the future, has, sooner than could have been anticipated, been converted into an event of past history. And to Lord W. Bentinck belongs the honour of this noblo achievement. He it was who first resolved to supersede the Persian, in the political department of the public service, by the substitution of the English, and laid the fuundation for the same in every department, financial and judicial, as well as political. And having thus by one act created a necessity, and consequently an increased and yearly increasing demand for English, he next consummated the great design by superadding the enactment under review, which provides the requisite means for supplying the demand that had beeu previously created. And this united Act now bids fair to outrival in importance the edicts of the Roman, the Arabic and the Mogul emperors, inasmuch as the English language is infinitely more fraught with the seeds of truth in every province of literature, science and religion than the languages of Italy, Arabia or Persia ever were. Hence it is that I venture to hazard the opinion, that Lord W. Bentinck's double act for the encouragement and diffusion of the English language and English literature in the East will, long after contemporaueous party interests and individual jealousies and ephemeral rival- 
ries bave sunk into oblivion, be hailed by a grateful and benefited posterity as the greatest master-stroke of sound policy that has yet characterized the administration of the British Government in India."

Let the Government, he urged, use the Asiatic Society of Sir William Jones and James Prinsep as the official organ for dispensing its patronage of standard oriental writers and their translations. But for the true education of the learned themselves, as well as for the elevation of the illiterate millions, the vast ocean of oriental literature deserves Firdousi's satire on Ghuzni in all its glory: "The magnificent court of Ghuzni is a sea, but a sea without bottom and without shore. I have fished in it long, but have not found any pearl." "Is it not one thing," asked Duff, "to regard a literature as an inexhaustible field for literary, scientific and theological research, and quite another to cherish it as the sole nursery of intellect, morals and religion?" Nor was one who knew the relation of the English to his own Gaelic vernacular so enthusiastic for English as to dream that it could ever supersede the mother tongues of millions, or do more than give them a new wealth and power. He thus concluded his vindication of the enactment, and proceeded to show where it fell short of his own ideal :-

"Who, then, will hesitate in affirming that, in the meantime, the Government has acted wisely in appointing the English language as the medium of communicating English literature and science to the select youth of India? And who will venture to say that the wisdom of the act would be diminished if it guaranteed the continuance of English as the medium until the living spoken dialects of India became ripened, by the copious infusion of expressive terms, for the formation of a new aud improved national literature? . .

"What will be the ultimate effect of these yearly augmenting educationary forces? We say ultimate with emphasis, because 
we are no visionaries. We do not expect miracles. We do not anticipate sudden and instantaneous changes. But we do look forward with confidence to a great ultimate revolution. We do regard Lord W. Bentinck's Act as laying the foundation of a train of causes which may for a while operate so insensibly as to pass nnnoticed by careless or casual observers, but not the less surely as concerns the great and momentous issue. Like the laws which silently, but with resistless power, regulate the movements of the material universe, these educationary operations, which are of the nature and force of moral laws, will proceed onwards till they terminate in effecting a universal change in the national mind of India. The sluices of a superior and quickening knowledge have already been thrown open; and who shall dare to shut them $\mathrm{np}$ ? The streams of enlivening information have begun to flow in upon the dry and parched land, and who will venture to arrest their progress? As well might we ask with the poet :-

“" Shall burning Etna, if a sage requires, Forget ber thcinders and recall her fires?

When the loose mountain trembles from on high, Shall gravitation cease, while you go by ?'

"But highly as we approve of Lord W. Bentinck's enactment so fur as it goes, we must, ere we conclude, in justice to our own views and to the highest and noblest cause on earth, take the liberty of strongly expressing our own honest conviction that it does not go far enough. Truth is better than error in any department of knowledge, the humblest as well as the most exalted. Hence it is that we admire the moral intrepidity of the man who decreed that, in the Government institutions of India, true literature and true science should henceforth be substituted in place of false literature, false science and false religion. But while we rejoice that true literature and science is to be substituted in place of what is demonstrably false, we cannot but lament that no provision whatever has been made for substituting the only true religion-Christianity-in place of the false religion which our literature and science will inevitably demolish. . .

"Our maxim has been, is now, and ever will be this :Wherever, whenever, and by whomsoever Christianity is sacrificed on the altar of worldly expediency, there and then must the 
supreme good of man lie bleeding at its base. But because a Christian government has chosen to neglect its duty towards the religion which it is sacredly bound to uphold, is that any reason why the Churches of Britain should neglect their duty too? Let us be aroused, then, from our lethargy, and strive to accomplish our part. If we are wise in time, we may convert the act of the Indian Government into an ally and a friend. The extensive erection of a machinery for the destruction of ancient superstition we may regard as opening up new facilities, in the good providence of God, for the spread of the everlasting gospel, as serving the part of a humble pioneer in clearing away a huge mass of rubbish that wonld otherwise have tended to impede the free dissemination of divine truth. Wherever a Government seminary is founded, which shall have the effect of battering down idolatry and superstition, there let us be prepared to plaut a Christian institution that shall, through the blessing of Heaven, be the instrument of rearing the beauteous superstructure of Christianity on the ruins of both.

"Already has the Church of Scotland nobly entered upon the great field; but let her remember that she has only crossed the border. Already has she taken up a bold and commanding position in front of the enemy ; but let her not forget that the warfare is only begun. Let her arise, and in the name of the Lord march forward to take possession of the land. Already has she given evidence of the possibility, and an example of the mode of turning the Government schemes of education to profitable account. Where the Government had established its first English college there did she station her first missionaries and plant her first Christian institution. And some of the most talented of the young men reared in the Government college became, through the grace of the Divine Spirit, her first converts, the first-fruits of her missionary labours in Hindostan.

"We have often wondered at the boldness of the conception of a celebrated statesman, who, when taunted on the occasion of the last invasion of Spain by France, as to the diminution of British influence and the declension of British interests in the councils of Europe, which that event seemed to indicate, rose up in the British senate, and in substance made the magnificent reply: 'While others were torturing their minds on account of the 
supposed disturbance of the equilibrium of power among the European states, I looked at the possessions of Spain on the other side of the Atlantic: I looked at the Indies, and I called in the new world to redress the balance of the old.' What is there to prevent the Church of Scotland* from attempting to emulate, in a much higher and holier sense, the magnanimous spirit of this reply? If she awake and arise, and put forth all her latent energies in behalf of the perishing heathen, may she not, in reference to the glowing prospects of Christianity in the East, be yet privileged to show that, at a time when many upbraided her with the diminution of influence at home, and others were racking their ingenuity in adjusting the disturbed equilibrium of her power, she looked at the dominions of idolatry across the great ocean; she looked at the Indies and, through the blessing of God, called in a new Church to redress the balance of the old ?"

With the sensitive modesty which ever marked him, the eloquent adapter of Canning's saying made no allusion to his own part in this result, of which Trevelyan writes that it "entered largely" into the official side of the revival, and how much more largely into the spiritual! In the next year's report which he drafted, Trevelyan, remembering John Knox though writing of purely secular schools, declared it to be the Government committee's aim to establish a vernacular school in every village of India, and to endow a college for Western learning ultimately in every zillah or county town. In that one year the Government English schools were doubled in number, in Bengal and Northern India alone rising to twenty-seven. Accepting that so far,

The reason why the Church of Scotland is here singled out for special notice is, that the whole of the preceding article happened to be originally inserted in the Church of Scotland Magazine. Tho anthor, however, equally rejoices in all the real success that has attended the missionary labours of other Churches and societies, and nnites with all that sincerely love the Lord Jesus in earnest prayer and supplication for their increasing prosperity.-A. D. 
the new demand of its first missionary was, that the Scottish and other Churches should plant an institution beside such secular schools, to supply the people with the lacking elements of positive moral and spiritual truth. That, too, he of all men brought about, alike by the stimulus be gave to the other Churches to follow his example, and by the tolerant, catholic grant-in-aid system, which he did not succeed in securing till Parliament again interfered in 1853.

The conflict which resulted in the decree of 1835, and the discussion to which that ordinance in its turn gave rise, left a curious trace on the writings of $\mathrm{Mr}$. Gladstone and Macaulay three years after. Mr. Duff's complaint that the Government of India had made no provision for putting Christianity in the place of the false faiths which a true science and literature were destroying, rests on precisely the same principle to advocate which Mr. Gladstone, in 1838, published his first book on "The State in its Relations with the Church." When, on his return from India, Macaulay wrote his well-known essay on that most earnest volume, he met the proposition that the propagation of religious truth is one of the principal ends of Government, as Government, by considerations drawn from his Indian experience. From the other extreme of political expediency he assumed that the Government of India, while it "ought indeed to desire to propagate Christianity," should not attempt such substitution of the true for the false, because it would inevitabiy destroy our empire.

Thus was begun, first practically and then legislatively, that revival of letters in India, of which, referring to the Renaissance of the fifteenth and sixteenth centuries, Macaulay had written in his famous minute: "What the Greek and Latin were to the contemporaries of More and Ascham, our tongue is to 
the people of India." Similarly Duff had reasoned zears before that was written: What the Christian Reformation did for Europe through the Greek tongue, the Roman law and the Bible in the vernaculars, it will similarly do for India and further Asia through the English language and the British administration. It is difficult to say whether he showed more genius in instinctively seizing the position in 1830, in working out the parallel down to 1835 , or in influencing the Indian Government and the British public by bis heaven-born enthusiasm and fiery eloquence. 


\section{CHAPTER VIII.}

\section{3-1835. \\ THE RENAISSANOE IN INDIA.-SCIENOE AND LETTERS.}

The Duff-Bentinck Period-The Aryan Witness to Christian Doctrine.-Medical Science and Practice in Vedic times.-Charaka and Susruta.-First Attempt of un Indian Goverument at Medical Teaching in 1822.-Duff Protests against the Unscientific Folly of the Orientalists.-Lord William Bentinck's Committee.-Sir C. Treveljan's Narrative.-Duff's Brahmanical Students offer to Dissect the Hn man Subject. - The Bengal Medical College created. -Bramley, Henry Goodeve and the First Professors.-Modısoodnn Goopta and the First Dissection.-Subsequent Success of College and Native Christian Physicians.-The Controversy about Romanizing the Oriental Alphabets.-The 539 Languages and Dialects of Further Asia.-Sir C. Trevelyan's Acconnt of Daff"s Assistance.-Duff's Work for Vernacular Education.-Adam's Reports on the Indigenous Schonls - Duff uses the Press.-Establishes the Calcutta Christian Observer.-Opinions on Biblical Criticism.-Freedom of the P.ess permitted by Lord W. Bentiuck, and legally secured by Metcalfe.-In what sense a Renaissance is true of India.

Doring what may appropriately be marked out as this Duff-Bentinck period, the Hindoo mind began to awake from its long sleep under the dominance, first of its own Brahmanism broken only for a time by the Buddhist revolt, and then of the Arab-Muhammadan tyranny, to which it had early lent the culture of the caliphs of Bagdad down to that of Akbar at Agra. The nineteenth century in India is the beginning of a renaissance in a sense which promises to be as real for Southern and Eastern Asia as that of the fifteenth was for Europe. In philology and philosophy, in astronomy and medicine, the Vedic Hindoos were the 
teachers of Pythagoras and Plato, of Aristotle and Ilippocrates, as well as of the Arabs who, like Ibn Sina, called Avicenna in the dark ages of Europe, preserved the teaching of both Hindoos and Greeks for the coming revival of letters in the West. What was the relation of the Hindoo Aryans to the Accadian or Chaldean and the first Semitic or Egyptian civilizations, is still a problem for the solution of which scholars are painfully collecting the materials. Even in faith, just as Rammohun Roy went back on the Vedas and Kesbub Chunder Sen, his present representative at the head of the Brumho Somaj, professes still to find there the body of natural religion, so the Rev. Dr. K. M. Banerjea, the first convert baptized by Duff, appeals to his countrymen to give up their idolatry and caste, by "The Aryan Witness, or the Testimony of Aryan Scriptures in corroboration of Biblical History and the Rudiments of Christian Doctrine." He beseeches them to turn-to returnto Christianity as to the fuller, because anew revealed embodiment of what the Vedas mysteriously proclaimed, that "the Lord of the creation offered himself a sacrifice for the benefit of gods," that is, of the mortals he redeemed for heaven; and that the same Lord, "the giver of self," initiated the rites of sacrifice which is a "reflection" of himself.

This renaissance, this bringing to the birth again in faith, in philosophy, in philology, was no less remarkable in science. The Vedic system, which had given the West the knowledge of numbers and of the stars, down even to the nine numerals which we incorrectly ascribe to the Arab middlemen who only revived their use, was the first to teach the healing art, according to the greatest living authority, Weber * The

- See his History of Indian Literature (1878), pp. 30 and 265. 
regulation of the sacrifices required alike astronomical observations and anatomical practice. The victim was carefully dissected that its different parts might be assigned to the proper deities. Each part had its distinctive name. In the Atharvan, one of the four great Vedas, we find songs addressed to diseases and to the herbs which heal them. Even in Alexander's time his companions praised the Hindoo physicians, and ascribed to them that specific for snake-bite which has so perished, that all the researches and the science of Sir Joseph Fayrer and the old medical service of India have failed to re-discover it. To medicine the Hindoos assigned a secondary scripture, the Ayur Veda, or "science of life," and derived it, like the four Vedas, directly from the gods. Their first historical writers were Charaka, at the head of all surgery, and his disciple once removed, Susruta, chief of all physicians before Galen. The number of their medical works and authors Weber pronounces "extraordinarily large," and the sum of their knowledge he declares to have been " most respectable."

In surgery European savants have borrowed from them the operation of rhinoplasty. Even so late as 1460, Colot, the famous surgeon of Louis XI., begged a man's life from the gallows in order to prove that the operation of lithotomy was not necessarily fatal, and the man lived. But the common Bhoidos of India had successfully practised the operation since Charaka's time. So with the process for cataract, to perform which the princes of Europe used to send into Asia for oculists. Dr. Allan Webb, when professor of descriptive and surgical anatomy in the Bengal Medical College, in 1850, told his Hindoo students: "It is very true that the itinerant Bhoidos do occasionally poke out eyes, but it is equally true that $I$ have seen in various parts of India many eyes to which they had 
restored sight." Embryotony and mesmerism, not to mention more, have been successfully practised in India for ages.

But the oppressive and corrupting influences of the sacerdotal Brahmans soon extinguished the dim light of scientific observation and practice in Southern and Eastern Asia. Gifts to themselves took the place of natural remedies. All knowledge, every form of truth they laid upon their own bed, which was narrower than a man could stretch himself on. Happily for the millions whom they have thus deluded for centuries, from Cape Comorin to Java and Lhasa to Peking, the scientific falsehood became easily manifest at the first touch of the senses honestly applied. Disintegration began when Duff demonstrated the cause of the first eclipse which took place after be opened his school. Every day's teaching, even apart from revealed truth which shows the divinity of its origin by concerning itself only with man's spiritual nature, hastened the process, which is as rapid in the secular as in the Christian college. In spite of itself the East India Company, which ignorantly desired to maintain Hindooisin for political ends, made its secular teachers missionaries of destruction at least, when for the " rubbish" which astounded Bishop Heber at Benares they used English to give full play to the evidence of the senses. The elemental theory of medicine which Plato and Hippocrates had learned from Charaka and Susruta fell with the cosmogony of the tortoise. Of science as of faith it became true for a time, that the educated Bengalee mind was empty, swept and garnished.

Moved by the purely utilitarian consideration of providing native doctors or dressers for the army hospitals, Government established the native Medical Institution in Calcutta in 1822, under an English 
doctor and native assistants. Hindostance, the lingua franca of all India, was the language of instruction, and the scientific nomenclature of the West was rendered into Arabic. Four years after, medical classes were opened at the Sanscrit College to read Charaka and Susruta, and at the Madrissa to study Avicenna and the other Arabic writers. Thus the orientalists dreamed they could give the people of India the blessings of the healing art as developed in the West, just as they persisted in spending that people's money on the printing of books which their scholars scorned, and in the payment of youths to learn what was despised because of its methods and what was pernicious because of its falsity. Dr. Tytler, the head of the new institution, was one of the most fanatic of the orientalists. His translations, afterwards condemned by his own medical brethren, proved to be among the most costly of the wasteful publications. The only anatomical instruction which he dared or desired to give, was from sundry artificial preparations or models, from the lower animals, and occasional post mortem. examinations of persons dying in the general hospital. For a Hindoo of caste to touch a dead body, even that of his father, was pollution to be atoned for by days of purification and much alms. To break through that iron prejudice Dr. Tytler and the orientalists declared to be impossible, and they did not try. Yet their own little scholarship, or unscholarly prepossessions, did not carry them so far as to translate Susruta. They would have learned that the literature classified under the term "Ayur Veda" carefully provides for dissection of the human subject, and that after a fashion so disgusting as almost to justify the later superstition. It was to be made a putrid carcase by lying for seven days in still water, and then to be rubbed so that each integument and part might be studied. 
But, adds the Galen of India, who was no materialist, " the life of the body is too ethereal to be distinguished by this process."

Duff was roused, by his own principles and his daily experience in the school, to protest against Dr. 'Tytler's folly. If his teaching were of force that all truth is a unity, and that for the Hindoos of that generation truth could be got only through the language of their rulers, of Shakespeare and Bacon, and the Bible of James, it was of force in every branch of learning, scientific and practical as well as other. "Only use English as the medium," he declared, "and you will break the backbone of caste, you will open up the way for teaching anatomy and all other branches fearlessly, for the enlightened native mind will take its own course in spite of all the threats of the Brahmanical traditionists." In 1833 Lord William Bentinck, not less attracted by the controversy than compelled by the deplorable state of medical education, appointed a committee to report on the whole subject. The members were: Surgeon J. Grant, the Apothecary General; Assistant-surgeons Bramley and Spens, Baboo Ram Komul Sen, T. C. C. Sutherland, the secretary to the Committee of Public Instruction, and Sir C. Trevelyan. For twelve months did these authorities, professional and educational, take evidence and deliberate, having submitted to the combatants on both sides from forty to fifty detailed questions. What was the effect of Duff's answers to these, following his experience, we are enabled by Sir Charles himself to show in this account of the conflict:-

"It was now proposed to raise up a class of native medical practitioners, educated on sound European principles, to supersede the native quacks, who, unacquainted with anatomy or the simplest principles of chemical action, preyed on the people, and hesitated 
not to use the most dangerous drugs and poisons. The battle which had been so well contested in the Education Committee was fought over again in this new field. The superintendent of the Medical Institution, a learned and enthusiastic orientalist, set in array the arguments of his party, and confidently predicted the failure of the attempt, while Dr. Duff took the opposite side. The following extracts from the report of the special committee show how largely we are indebted to him for this great reform :-

"The Rev. Mr. Duff, on the other hand, although acknowledging that the native languages, by which we understand the Bengalee in the lower provinces and the Urdu in the higher, alone are available for imparting an elementary education to the mass of the people, affirms that the popular langaage does not afford an adequate medium for communicating a knowledge of the higher departments of literature and science. 'No original works of the description wanted,' he observes, 'have yet appeared in the native languages; and though much of a highly useful nature has been provided through European talent and perseverance, no translations have been made in any degree sufficient to supply materials for the prosecution of the higher object contemplated; neither is it likely in the nature of things that, either by original publications or translations of standard works, the deficiency can be fully or adequately remedied for such a number of years to come as may leave the whole of the present generation sleeping with their fathers.'

"We beg now to call your Lordship's attention to the opinions of the Rev. Mr. Düir. To the question whether, in order to teach the principles of any science to native bors, he considered it necessary that they should know Sanscrit, Arabic and Persian, the reverend gentleman replies that, 'In reference to the acquisition of European science, the study of the languages mentioned would be a sheer waste of labour and time; since, viewed as media for receiving and treasuring the stores of modern science, there is at present no possible connection between them.' On the other hand, in reply to the question whether he thought it possible to teach native boys the principles of any science 
through the medium of the English language, he replied that - the experience of the last three years has, if possible, confirmed the conviction he previously entertained, not merely that it is possible to teach native boys the principles of any science through the medium of the English language, but that, in the present incipient state of native improvement, it is next to impossible to teach them successfully the principles of any science through any other medium than the English.' Ho further records his opinion, that the study of the English language might be rendered very popular among the natives. 'The sole reason,' he justly observes, 'why the English is not now more a general and anxious object of acquisition among the natives, is the degree of uncertainty under which they (the natives) still labour as to the ultimate intentions of Government, and whether it will ever lead them into paths of usefulness, profit, or honour; only let the intentions of Government be officially announced, and there will be a general movement among all the more respectable classes.' But the teaching of English acquires much importance when we consider it, with Mr. Duff, as the grand remedy for obviating the prejudices of the natives against practical anatomy. 'The English language,' he urges, 'opens up a whole world of new ideas, and examples of success in every department of science; and the ideas so true, and the examples so striking, work mightily on the susceptible minds of native youth; so that by the time they have acquired a mastery over the English language, under judicious and enlightened instructors, their minds are almost metamorphosed into the texture and cast of European youth, and they cannot help expressing their utter contempt for Hindoo superstition and prejudices.'

"There is an argument of fact put in by Mr. Duff, which is admirably to the point. We allude to the introduction of the English language and of English science among the Scottish Highlanders, whose native language, to this day, is the Gaelic. The parallel is a very fair one; for no people were more superstitious, more wedded to their own customs, and more averse to leaving their native country, than the Highlanders: but since the introduction of the English language among them, the state of things is much changed. The same observation applies to Ireland and Wales, where, as in the Highlands of Scotland, the English is a foreign language; and yet its IO* 
acquisition is eagerly sought after by the natives of all these countries as an almost certain passport to employment. There are medical men, natives of these countries, scattered all over the world, whose mother tongue is Welsh, Irish, or Gaelic, which, as children, they spoke for years-just as the children of European parents in India speak Hindostanee and Bengalee; with this difference, however, that the latter soon forget the Oriental tongues; while the youth who acquire the indigenous language of Ireland, the Scottish Highlands, and Wales, never lose the language of those countries, because they do not quit them till a more advanced period of life. For the first years of youth the Highlanders at school, even of all ranks, think in the Gaelic; but this does not prevent their acquiring such a fluent and business-like knowledge of English as to enable them to pass through life with credit and not unfrequently with distinction. What is there in the condition, physical or moral, of the natives of this country that should render them incapable of acquiring English as easily as the Irish, the Highlanders, and Welsh ?"

"The expectations with which this change was made have been completely realized. The most intractable of the national prejudices has given way before the exigencies of the dissecting room, and European medical science has taken root in India, whereby one of the greatest boons ever conferred on suffering humanity has been extended to that country."

This was not all. Duff supplied the old solutionsolvitur ambulando. The commission visited his school, in common with all in which English was taught, but he did not forewarn the youths of their coming. Taking the senior class, which had been nearly four years under English instruction, into a small room by themselves, he invited the visitors to make any inquiries in any way they chose. Timidly and after a roundabout fashion did the Apothecary General approach the dreaded subject of dissection, for the first thing he learned and indeed saw was that the lads 
were chiefly Brahmans. He thus began: "You have got many sacred looks, have you not?" "Oh yes," was the reply, "we have many Shasters believed to be of divine authority. Some are very old, and others have been written by Rishis (holy sages) inspired by the gods. They are upon all subjects, literature, science such as it is, chronology, geography and genealogies of the gods." "Have you not also medical Shasters, which profess to teach everything connected with the healing art?" "Oh yes," they said, "but these are in the keeping of the Bhoido or physician caste; none of us belong to that caste, so that we do not know much about them." "Do your doctors learn or practise what we call anatomy, or the examination of the human body with a view to ascertain its real structure in order skilfully to treat wounds, bruises, fractures, etc.?" "We have heard them say that anatomy is taught in the Shasters, but it cannot be like your anatomy." "Why not?" "Because respectable Hindoos are forbidden by imperative rules of caste to touch a dead body for any purpose whatever ; so that from examination of the dead body our doctors can learn nothing about the real structure of the human body." "Whence then have they got the anatomy which, you say, is taught in the Shasters?" "They have got it out of their own brains, though the belief is that this strange Shaster anatomy must be true or correct, it being revealed by the gods; but we now look upon this as nonsense." "What then," said the commissioner, " if the Government should propose to establish a medical college for Hindoos under European doctors like the medical colleges in Europe? Would you approve or disapprove of such a measure, or how would it be viewed by the natives generally?" "We certainly who have been taught European knowledge through the medium of English would cordially approve, but 
our ignorant orthodox countrymen would as certainly disapprove." "Well then, were a college of this kind established, would any of you be disposed to attend it; or would there be insuperable objections in your minds against your doing so?" "Not at all," they said. "If we were not already otherwise committed to some course of life which would prevent us, we would be very glad to attend." "What!" said the commissioner, "would you actually be prepared to touch a dead body for the study of anatomy?" "Most certainly," said the head youth of the class, who was a Brahman; "I, for one, would have no scruples in the matter. It is all prejudice, old stupid prejudice of caste, of which I at least have got rid." The others heartily chimed in with this utterance. The commissioners were highly gratified. The result of their inquiry exceeded their most sanguine expectations. They thanked the young men for the promptness of their response, and promised to report their liberal disregard of hereditary prejudice to the Governor General. His Excellency's surprise did not prevent him from completing the case by consulting the orthodox pundits. These reported that the prohibition against touching a dead body was most. stern, but they did not find it anywhere expressed in the Shasters that Hindoos are forbidden to touch the human subject for anatomical purposes. Yet both these and the Muhammadan Moulvies stirred up the community to petition the Government to remain satisfied with the study of the Sanscrit and Arabic treatises.

Nor was Duff alone in this. David Hare, of the Hindoo College, seems to have been equally zealous, although we have no record of his action beyond the fact. The Governor-General in Council embodied the unanimous conclusions of the special committee in an order dated 28th January, 1835, abolishing the 
Medical Institution and classes, and creating a new college under the Committee of Education for " the instruction of a certain number of native youths in the various branches of medical science." The new colleg( $)$ was declared open to all classes of natives, without exception as to creed or caste, who could read and write English and Bengalee, or English and Hindostanee. Eurasians and Europeans were afterwards included. The English language and the Western scientific standards were declared the medium and the test of instruction. On the 1st June, 1835, the classes were opened in an old house in the rear of the Hindoo College, only to be removed by Lord Auckland to a building then pronounced "magnificent," but long since too small for the thousands who form what has proved to be the largest medical school in the world. Dr. Bramley, the first principal, died soon after, and the early success of the great experiment is associated with the name of Dr. Henry Goodeve, who still survives. With him were associated the Danish botanist of Serampore, Dr. Wallich; the Irish professor of chemistry, Dr. O'Shaughnessy, who gave India the electric telegraph, and two others. David Hare was secretary. Nobly, not less effectually than Duff's ardent enthusiasm predicted, has the Bengal Medical College, with its hospitals, under the ablest members of the Company's medical service and Bengalee professors who have risen from the students' benches, realized what Lord W. Bentinck's committee aimed at when it laid down for it a curriculum " ample, comprehensive and worthy of a great Government, not intended merely to supply the wants of the State but of the people, and to become a moral engine of great utility and power."

How did Duff's Brahman students and those of the Hindoo College stand the test when the hour came for 
the first dissection? That hour came after the first six months' study. The time was then recalled when the medical class in the Hindoo College met for the first cutting up of a kid, and the college gates were closed to prevent popular interruption of the awful act! Following his professor, Modosoodun Goopta, of the Bhoido or physician caste, was the first native to handle and plunge his knife into the subject provided for the purpose. Rajendranath Mitter followed, and their fellow-students quickly imitated this act of moral courage. Thus, nearly three thousand years after Susruta and his loathsome instructions, the study of practical anatomy by the natives of India was established. So fast did it spread, that a purely Hindostanee class and then a Bengalee class were opened, to meet the need of subordinate assistants in the military and civil hospitals, and of the cities and villages of the country. From sixty in 1837 the number of subjects for the dissecting room rose to above five hundred in 1844, and now must be three times greater. Dwarkanath Tagore and Dr. H. Goodeve soon took four students to England to seek a British diploma; of these two were Christians and one was a convert of the General Assembly's Institution. Ever since, Duff's college has sent some of its ablest converts as well as Hindoo students to take the highest honours in the medical faculty of the Calcutta University. One of them is now a professor in the Medical College, and several have entered the covenanted service by competition with Scottish, English and Irish graduates. The tale of what the medical colleges of India-for others sprang up in imitation of Bengal, at Bombay, Madras, Lahore and Agra-have done for humanity, for the sciences allied with medicine, and for enlightenment throughout the peninsula, in the half-century since Duff began his apostleship, would form one of the most 
brilliant chapters in the history of progress, but it is not for us to tell it here.

In yet a third field did Duff and Trevelyan, aided by that accomplished scholar of the Baptist Mission press, Dr. Yates, meet the orientalist party. The committee of the Calcutta School Book Society was the scene of the conflict. That body had succeeded in supplying pure English literature to the natives on mercantile principles, while the Government Oriental colleges had their shelves groaning under expensive works which no native would take as a gift, unless also paid to read them, and at which true scholars laughed. In $1833 \mathrm{Mr}$. Thompson, a Government teacher at Delhi, sought the patronage of the society for an English and Hindostanee dictionary in the Roman character only, designed to assist natives of the upper provinces in the acquisition of English and Europeans in the study of Hindostauee. Dr. Yates, as secretary, recommended the purchase of two hundred copies. Mr. James Prinsep condemned the use of the Roman alphabet by any but Europeans as "ultra-radicalism." Dr. Tytler, whose foible was a desire to stand well with the few Oriental scholars in Europe, protested that such a book would "compromise our character very much, particularly with European scholars, in whose eyes the Oriental literature of Calcutta does not stand very high at present." Sir Charles Trevelyan demolished both in a long minute, in which he exposed the unscholarly character and expense of Dr. Tytler's translations, showing that Rs. 105,426 (£10,543) of public money had thus been wasted in the ten years since 1824. On this James Prinsep cast the broad shield of his genuine learning over the wounded Tytler, in a minute which consluded with this retort on the alleged superiority of English to Sanscrit or Perso-Arabic orthography :- "I 
never heard of a mother who did not complain of the difficulty of teaching a child the difference between $\mathrm{C}$ and $\mathrm{S}$, and $\mathrm{I}$ will ask whether a native child . . would as readily recognise the 'City of God' (Allah$a b a d)$ in the "isle of bats' and the "palace at Ghazeepore' in 'Chelsea tune' (chuhul sitoon)." Dr. Tytler felt as grateful to James Prinsep as Homer's hero when, worsted in battle, he was hid under the apron of his celestial mother, Aphrodite. After Trevelyan had slain Prinsep, Duff entered the field through the press and anonymously, while Mr. H. Thoby Prinsep in turn brought the heavy artillery of the Asiatic Society to bear upon him.

The merits of the controversy are these: In the East Indies, as influenced from their metropolis Calcutta-including in that term Dutch Java and now French Anam-there are eight distinct ethnological families, containing 243 spoken and written languages and 296 dialects of these languages, or 539 in all. These have to be mastered-having been reduced to writing in many cases by missionaries and officials before the half of the human race who use them can be influenced for good. They present two sets of difficulties, arising from their varying written characters and very different grammatical structure. Can the former class of difficulties not be removed or modified? If the English language and literature are to be used as the medium and the instrument of civilzation in the effete East, why not the one Roman alphabet in which they are expressed?-such was the very natural reasoning of the Anglicists of 1833. That this is no dream may be accepted from the fact that the great scholar Lepsius has prepared a "standard alphabet," and that the Boden Sanscrit professor at Oxford is an earnest advocate of Romanising, while Professor Max Müller has a similar plan of his own. 
One character is necessary, and that has, of course, been the Roman thus far for tongnes reduced to writing for the first time by missionaries, who desire to tell and write for these simple people "the wonderful works of God" in Christ. But more than this, Mr. Cust is within the truth, as every scholar will admit, when he declares, "It may be accepted as a scientific fact that all the characters used in the East Indies can sooner or later be traced back to the Asoka inscriptions, and through them to the Phœnician alphabet, and thence backwards to the hieratic ideographs of the old kingdom of Egypt, and thence to the venerable hieroglyphics of the fourth dynasty." The solitary exception is the Chinese character used in Anam.*

More than three rivals compete to represent the 539 languages and dialects, for the Indian, Arabic and Roman are complicated by additions or adaptations to represent all the sounds of each, till religion is invoked to consecrate some, so that the orthodox Hindoo will not use the Perso-Arabic, nor the strict Muhammadan the sacred Nagree. If one alphabet in the good Asoka's days, not long after Alexander the Great, why not one again-why not one at any rate, and that the Roman, for all the peoples who learn writing, and even reading, for the first time from the Christian missionary and the British and other European Governments in Asia? Though deprecating as injudicious and impracticable any attempt to supersede the established characters of cultivated languages by the introduction of the alien Roman character, Mr. Cust urges the use of the standard of Lepsius in the case of languages hitherto unwritten. In 1878 he used this language, which is the echo of Duff's half a century

- 1 Sketch of the Modern Languages of the East Indies. 1878. 
ago:- "It is a remarkable phenomenon that the fountains of so many languages and dialects should have been unsealed just at the moment when the intellectual, mechanical and religious powers of England and Holland were at their height, ready to undertake the task of translating the Bible into scores of languages, for which task, even if the opportunity bad offered itself, English scholars were, last century, as unfitted as the Spanish and Portuguese are even now unfitted, and as nnwilling to lend themselves to the task as the Italians, French and Russians are even now unwilling."

We have received this narrative of Duff's advocacy of the Romanising system from Sir Charles Trevelyan, who sought officially to carry it out when Governor of Madras. He has recently published as an illustration of it " Rábinsan Krúso," being a translation, through the Hindostanee, of Defoe's immortal work into Persian in the Roman character. To that Mr. Tolbort, of the Bengal civil service, as editor, has prefixed an exposition and defence of the application of the Roman alphabet to the languages of the East, declaring that that alphabet "will be to the education of Asia what George Stephenson's rails were and are to the locomotive steam engine." The system of transliteration was that of Sir William Jones, who followed the Italian or continental European sound of the vowels, while Dr. Gilchrist afterwards sought to fix them to the more familiar of their various sounds in English. Thus the wellknown "Ameer" of the latter is the "Amír" of the former, and the "Punjab" is "Panjab." The advantage of the Gilchrist transliteration of proper names for purely English readers is evident; that of the Jones system for Romanising and strictly scholarly purposes is not Iess so. The German orientalists have recently published a whole series of the Oriental classics in Roman type. In the twenty years ending 1857 the Bible, 
the Pilgrim's Progress, the Koran, and forty-three other religious or educational works had appeared in Romanised Hindostanee. Sir C. Trevelyan writes :"It was proposed to extend to India the advantage which Europe enjoys of making one character serve for many different languages and dialects, whereby it might be at once seen how far they agreed or differed, and a tendency might be created towards a common Indian language and literature, of which English would be the connecting link, and the Christian religion the principal source of inspiration. Eastern writing is thoroughly phonetic; that is, the due relation of sign and sound is consistently maintained throughout, so that a simple transliteration into the Roman character gives a correct representation of the sounds in all the native languages; and during the long period which has elapsed since the invention of printing, the typography of these letters, with all its accessories of punctuation, capital letters, italics, and other mechanical helps, has been so improved that they have become a much more efficient and economical medium for expressing the languages of the East than the various alphabetical systems in actual use there. This would also be the salvation of the native languages, which have a hard struggle in their competition with the all-powerful English, freighted with so many substantial advantages, and it would have a highly salutary political effect by intimately associating our nation with the growth of the new Indian literature, and by removing a serious practical obstacle to satisfactory mutual intercourse.

"This system has made steady progress, notwithstanding every discouragement, and its advantages have become so generally recognised that effectual arrangements are likely soon to be made for its gradual adoption; but the undertaking might have been 
strangled in its birth if Dr. Duff had not given it his strenuous support. The turning point of the controversy was marked by the publication of three papers by Dr. Duff, in the first of which the 'possibility,' 'practicability,' and 'expediency' of substituting the Roman for the Indian alphabets was discussed, and in the last two a practical scheme for that purpose was worked out in detail, and objections were answered. These papers give a high idea of the logical powers and critical acumen of Dr. Duff. They settled the system on its present basis, and may be read to this day with interest and advantage.

"It was impossible to work, as I did, with Dr. Duff, without having his character clearly unfolded before me, and I must be allowed to indulge my feelings by briefly saying what I think of it. He combined childlike simplicity and sincerity with intellectual powers of no mean order, and his fervid Celtic nature imparted warmth and energy to everything he undertook. His disinterestedness, and freedom from selfish motives of all kinds, appeared to me to be perfect. His whole being seemed to be engrossed in the one great object of his life, compared with which all merely personal motives were of secondary consideration. He was a truly loveable character. My feeling towards him is compounded of affection and respect, and I should find it difficult to say which of these predominates."

Thus far the battle begun and carried on by Duff had been for the people. English he fought for, as the weapon of truth's warfare at that stage not only against the intolerance of the quasi-orientalists who squandered the people's money on a fer scornful Brahmans and Moulvies, but against the equal intolerance of their own leaders in the Hindoo College, who excluded the lower castes even from secular instruction. Through the natural heads and respectable 
castes of the Hindoos he deternined that Western truth and English benevolence should reach the masses and fertilise the literature of their mother tongue. Hence his own early devotion to Bengalee at a time when his busy nights were no more his own than his exhausting days, and the instinct of genius drove him to take the tide of English in native society near the flood that he might guide it to faith and all that a reasonable faith here involves, in social purity, in public enlightenment, in national revival. Hence the Bengalee department in his school, and the simultaneous teaching and reaction on each other of English and the vernacular. Without that the taunt of the barren orientalists might have had some justification. English might have become only another official jargon like court Persian, to be used by the initiated few for the oppression of the many, and the widening of the gulf between alien rulers and ignorant ruled. From that memorable Monday, 2nd of August, 18:30, when the Highland lad opened his school with our Lord's Prayer in Bengalee, to the day just after the Mutiny, when he introduced the Christian Vernacular Education Society into Calcutta, and down to his last effort for India, having put English in its right place chronologically and educationally, he sought to have India covered with primary schools worthy of the name.

Here, also, the Government of Lord William Bentinck came to his help and did its duty. The same ever to be remembered months at the opening of 1835 , which legislatively brought to the birth the Renaissance in science and letters, by the medical college and English language decrees, saw the first official step taken in the application of both to the varied vernaculars of India. On the 20th January "W. Bentinck," with whom his colleagues, the Honbles. 
H. Blunt, A. Ross and W. Morison "concurred entirely," wrote the minute which sent Mr. Adam, for seventeen years a missionary and then editor of the India Gazette, to visit and report on all the existing vernacular schools in Bengal. The minute began with the "universally admitted axiom that education and the knowledge to be imparted by it can alone effect the moral regeneration of India." At a time "when the establishment of education upon the largest and most useful basis is become the object of universal solicitude," the minute wisely declared it essential to ascertain the actual state of education as carried on for centuries entirely under native management. It deprecated interference with these before Government knew the facts, and direc $\downarrow$ inquiry by officials as certain to excite distrust. Hence the appointment of Adam, whose three reports, the more that they prove his intelligent philanthropy and administrative wisdom, reflect severely on the stupid apathy of the Committee of Education, which shelved them and drove him to resign in disgust. He showed that, as Duff put it, $92 \frac{1}{4}$ out of every hundred children of school-going age in Bengal were destitute of all kinds and degrees of instruction. That is, on the basis of the under-estimated population of that time, six millions of such children were wholly uneducated. Yet not for twentytwo years thereafter would Government do anything for Bengal. Not till Dalhousie was Governor-General was anything done for Upper India save by the missionaries. So the evil round goes on under the system which breaks the continuity of progress in India-the five years term of ligh office. A Bentinck takes his seven years' ripe experience with him, to be followed by a reactionary Auckland. We shall not bring the illustration down to our own day. Missionaries like Duff in Eastern, Wilson in Western, and 
Caldwell in Southern India alone remain immortal till their work is done!

In all his work and at every stage of it Duff felt that he had a more powerful ally and instrument than even Lord William Bentinck as Governor-General, and that was the Press. From the outset of his career writing went hand-in-hand with teaching and public speaking. The relation of his new ideas to the few native papers, English and vernacular, according as they opposed, misrepresented or advocated them, and his plan of replying by public discussion to the attacks of their correspondents; we have seen. The Serampore missionaries had, before him, filled the breach, alike by their quarterly Friend of India and by Mr. Marshman's establishment of the first Bengalee newspaper. So that, whereas in 1814 there was only one English periodical and not one native in all Bengal, and in 1820 five English papers and still not one Bengalee print, in 1830 there were eight native papers. But Duff had not been twelve months in Calcutta before he saw the necessity of establishing a Magazine to represent missionary and philanthropic operations of all kinds, and to bring Christian opinion to bear upon Government on the one hand and the educated natives on the other. Hence in June, 1832, appeared the first number of the Calcutta Christian Observer, "edited by Christian ministers of various denominations." The signature "D" marks the authorship of the introductory programme. Besides the sectarian periodicals then in Calcutta, he sought "something unconfined by any trammels of party or of sectsomething that will embrace with impartial and comprehensive view the wide domain of Catholic Christianity." He desired to produce a periodical which should do for religion in the East what James Prinsep's Journal of the Asiatic Society accomplished for science 
and the Calcutta Magazine laboured to effect for literature. The six divisions of the Magazine he mapped out as theoretical and practical theology, Biblical criticism and translation, missionary operations, European and native institutions and events, reviews of books, intelligence of progress of all kinds, amid controversy and resistance, for only eventually may " the great Christian temple, like its material prototype of old, be raised with noiseless harmony of design and execution." The passage relating to the second division has a peculiar interest :-

"It is not necessary that the majority, or any very considerable portion of the Christian public should be Biblical critics or translators. - . But, however true that the great doctrines of revelation are so potent as to have produced but one persuasion in the minds of the immense majority of devout believers in every age, it is not less true that even these have been repeatedly and variously impugned. And as the Scriptures were written in ancient and dead languages, none who were ignorant of these could venture to elicit and set in array the genuine force of scriptural evidence. Hence arises one of the most important offices that devolves upon the Biblical critic. Again, the Bible containing, as it does, an historical and prophetical account of the most interesting events that transpired on the stage of this world for 4000 years, as well as of the extraor: dinary dispensations of the Almighty, must naturally and unavoidably include in its contents many 'things hard to be understood.' Now these are the things which, surrounded as they are by many luminous points, cost the pious believer least trouble. But these are the very things upon which the unbeliever is ready to pounce with more than the ravenous speed of an eagle upon its prey. In the reasonableness of this conduct he resembles the man who, withdrawing his view from 
the gorgeous productions of the animal, vegetable and mineral kingdoms, and the combined glory of the summer's landscape, would point in a tone of triumph to the meanest reptile or weed, or to the dampest and most dingy cavern, in proof of the worse than gratuitous assertion that the external world contained nought that was fair, beauteous, or lovely. Every person of common sense and common honesty would regard such a procedure with merited contempt and indignation; while the zoologist, the botanist and the mineralogist would follow him still further, and by evolving the hidden beauties and harmonies of what has been so rashly decried, convict him of the most presumptuous empiricism. Now, what service these men of science are enabled to render in rescuing even the most despised of the works of God from the reproaches of the ignorant, the very same is the Biblical critic expected to render on the hard and dark things-the abstruse and apparently profitless parts-of the Word of God. To be fully qualified for a task so arduous, he ought of all learned men to be the most learned."

The Observer became, under Duff's influence and that of his colleagues during his absence from India, all that he thus desired; while from 1835 to 1875 the Friend of India, changed by Mr. J. C. Marshman into the powerful weekly newspaper which it long continued to be, applied the same Christian principles in a more purely political and broadly imperial way to the elevation of the whole empire. At the same time we shall see him using, for the highest ends, the English daily journals of Calcutta as he used the Anglo-Bengalee newspapers, and in his second term of service in Bengal editing the Calcutta Review.

The coarse licence of Hicky's Gazette, the first Eng. lish newspaper published in India, in 1780, followed by that of the Bengal Journal, led the Company's 
authorities, in 1794, to deport the editor of the latter, Mr. William Duane, because of an inflammatory address to the army. During the war with Tippoo Lord Wellesley established a formal censorship of the press, which, made still more severe in 1813, continued till 1818, when Lord Hastings practically abolished it. George Canning, when President of the Board of Control, suppressed a severe condemnation of this act by the Court of Directors. But when Mr. John Adam became interim Governor-General, he gratified the bureaucratic instinct against criticism by reviving the censorship and deporting Mr. James Silk Buckingham, to please his rival, Dr. Bryce; who was at once senior Scottish chaplain, editor of the John Bull, and clerk of stationery! The weak Lord Amherst put Adam's most severe restrictions in force against Mr. Arnot of the Calcutta Journal, and warned the Bengal Hurliāru.

When Lord William Bentinck's financial reforms reduced the military allowances known as batta, he was covered with abuse which might have tempted other men to crush the self-seeking critics. But he knew and he loved the principles of freedom which his greatgrandfather, Hans Bentinck, had helped William III. to consolidate in England. He went further, declaring that the liberty of the press was necessary to the good government of the country, as supplying " that lamentable imperfection of control which, from local position, extensive territory and other causes the supreme council cannot adequately exercise." In 1831 he invited criticism and suggestions, with results seen in such works as the Honble. F. J. Shore's " Notes on Indian Affairs," and in the destruction of many an abuse. Most happily, however, it was left to a Bengal civilian and pupil of Wellesley to atone for the highbanded folly of an otherwise estimable administrator like John Adam. Charles Theophilus, first and last 
Æt. 29. BEgINNING OF the RENAISSANCE COMPLETED. $23 \mathrm{I}$

Lord Metcalfe, when acting as Governor-General, deliberately risked the permanent appointment, by the Act XI. of 1835, which Macaulay wrote, repealing all restrictions on the press throughout India, and leaving it, like all other institutions and persons, to the ordinary law of sedition and libel. Vernacular as well as English literature in India took a new start, hardly checked by the bureaucratic timidity of Lord Canning's advisers in 1857, and certain to be again freed from the less excusable action of Lord Lytton's councillors in 1877. Thus the birth of the Renaissance was completed. Thus the name of Metcalfe is linked with those of Macaulay, Trevelyan, Bentinck and Alexander Duff.

No one who knows history and is accustomed to weigh in its balances, sacred and secular, the causes and the tendencies of human progress, will be surprised that we have thus broadly applied the term Renaissance to the intellectual and spiritual movement started by Great Britain in Southern Asia in 1813, vitalised by Duff in 1830-35, and still in its vigorous infancy. That this movement is not a birth only, but a re-birth, those will most readily confess who know far better than the Brahmanizing orientalists of the East India Company the real splendour of the early Aryan civilization; the comparatively pure traditions which were the salt of Vedic nature-worship; the wealth of the Aryan languages which Helias itself never matched, while it borrowed from them; and the influence of all three, through Greek, Latin and Arabic, on Europe in the dark ages. That the waking up of the Hindoo mind is certain to prove a Renaissance not only in the Italian sense, but in the English-a reformation in the spiritual region, and a silent constitutional revolution in the political condition, is due to Alezander Duff. We have seen it in the Christian college which is the 
nursery and in the first converts who proved the seed of the Church. We have seen it in the English language, in Western science, in the liberty of printing, in the education of the people in their mother tongue, in the growth of a pure vernacular literature. $\mathrm{We}_{\mathrm{\theta}}$ have yet to watch the development in church and university, in literature and science, in social freedom and even in the political elevation that springs from the concession, without a struggle, of all the constitutional liberties which it took the ruling power centuries to consolidate for itself. But above and under all we shall continue to find this, as Europe and Scotland before all countries found, that the motive power and the principle of growth consist in the putting every Asiatic spiritually in that relation to God which the Divine Christ has alone revealed and guarantees. The missionary is thus before all others. Savonarola has survived the Medici, and Luther lives. 


\title{
CHAPTER IX.
}

\author{
1832-1835. \\ WORK FOR EUROPEANS, EURASIANS AND \\ NATIVE CHRISTIANS.
}

St. Andrew's Kirk.-Anglican and Presbyterian Sectarianism.-The Steeple Controversy.-The Battle of the Gilded Cock.-Fight for a Second Sunday Service.-A Boilean Wanted.-Sunday Observance in India.-A Boston Socinian and the Lord's Supper.Duff longs for Friendly Sympathy.-The Senior Chaplain of Madras.-Daniel Wilson and Lord William Bentinck.-Rise of the Eurasian Commanity.-First Charity Schools.-Origin of the Doveton Colleges.-The Civil and Religions Rights of Converts from Hindooism and Muhammadanism. - 'The first Writ of Habeas Corpus in India.-Dr. H. H. Wilson Apologises to the Missionaries.-Case of Brijonath Ghose.-Duff does the Bishop of Calcutta's work.-Castigates Mr. Longueville Clark.-His Power of Moral Suasion.-Bengal Asiatic and Agricultaral Societies.-Mr. and Mrs. Duff decline to attend the Governor-General's Ball.-Lord William Bentinck's Public Eulogy of Duff.-The School becomes an Arts and Divinity College.-Reminiscences of Duff in 1834 by a Bengalee Schoolboy.-The Bible and Tract Societies.-The Great Cyclone of May, 1833.-The panic-stricken Tiger.-Fever after Flood.-Duff's First Attack.-Visit of A. N. Groves from Baghdad.-A Day in the College.-Duft again stricken down by Dysentery. - Carried on board the John M'Lellan bound for Greenock.-The Precious Seed Germinating.

So early as the beginning of the year 1832, while Mr. Duff was steering his apparently frail boat in the very trough of the sea of Hindoo society, with no assistance and little sympathy from his own countrymen, he was called to minister in St. Andrew's kirk to the Scottish residents, and to help the Eurasians and the native Christians in their earnest struggles after toleration for themselves in the eye of the law and a good education for their children. Thus early he began the afterwards lifelong labours which ended in the estab- 
lishment of the Anglo-Indian Christian Union, and in the creation of the Doveton Colleges of Calcutta and Madras.

St. Andrew's kirk-in 1813 the fruit, like its fellows in Bombay and Madras, of much talking in obscure Scottish presbyteries, and much petitioning of Parliament by synods and general assemblies since 1793had never justified its existence. How Dr. Bryce, its first chaplain, went out to Calcutta in the same ship with Bishop Middleton we have told. A bishop must have his cathedral; so St. John's cburch, consecrated by the ministrations of Claudius Buchanan and Henry Martyn, to which Warren Hastings, his council and all the "factors" in the settlement used to walk to morning service, was enlarged and dubbed by the necessary name, until Bishop Wilson built St. Paul's Cathedral. It was still more requisite that the Scottish chaplain should have a church, and the Government selected as its site the spot on which Lord Clive's old court-house had stood, whence the name still given to the finest street in all the East. The Presbyterian had won the first move in the evil game of sectarianism which he and the Anglican bishop introduced into India. But, viewing the national Church of Scotland as a dissenting body, the bishop would not allow Government to give it a church with a steeple. The Scottish blood of more than half Calcutta was roused at this, for as to origin the Scotsmen were in the majority. They had the secret sympathy of the evangelical missionaries of the Church Missionary Society, whom Dr. Middleton liked no more than the episcopal and youthful representative of the same views in the see of Colombo now does. Long and loud raged the battle of the steeple. It occupied secretaries and honourable members of Council and the GovernorGeneral week after week, till the literature of the 
subject plunged the predecessors of future Dalhousies, Cannings and Lawrences in despair. The men who were equal to successful expeditions to Java, Mauritius and the Cape of Good Hope; who had conducted to a happy issue Burman and Goorkha wars, Maratha and Pindaree campaigns, confessed themselves beaten by the steeple controversy. Lord Hastings, himself a Scotsman, directed all the papers to be hurled at the heads of the directors who had sent out the ecclesiastical combatants. Equally baffled, the directors appealed to the Crown and its law officers, not sorry that the authority which had forced the Church establishment upon them should have a little more trouble. The decision was that, as equal in their own sphere to the Episcopalians, the Presbyterians should have their steeple, although the Government were paying a thousand pounds as ground rent for the site. Years had passed in the fight, but the national zeal had not waxed cold. There are steeples and steeples. Of what height was St. Andrew's to be? The kirk itself was a noble structure, and the steeple must correspond with it architecturally. To close the matter, the Scottish residents, in public meeting assembled, subscribed eighty thousand rupees $(£ 8,000)$ to add to the spire allowed by Government, so as to raise it to a point twenty feet higher than that of the cathedral, and they surmounted the whole by a cock to symbolise their crowing over the bishop. Against this Dr. Middleton renewed the fight, and the cock, like the steeple, occupied the discussions of the GovernorGeneral in Council and then of the Court of Directors. The decision was worthy of the most subtle of the ecclesiastical schoolmen, and of the satire of Boileau's "Lutrin." It must have been meant, by the James Mills, Charles Lambs or Thomas Love Peacocks who in those days draughted the despatches, as fine irony. 
When, it was ruled, the quinquennial repairs of the building come round, the public works authorities are not to gild the cock anew! The judgment was a new triumph, for the patriotic Scotsmen of Calcutta, for long thereafter, used to raise some five hundred rupees privately to regild the boastful symbol.

But it was one thing to revel in such warfare, and quite another to fill the kirk inside, with its spacious aisles and vast galleries, seated with eight humdred chairs, over which swung cooling punkahs for as many occupants. Dr. Bryce was more at home as editor of the John Bull and clerk in the stationery office. In due time he received as colleague a man of a very different stamp, the Dr. Brown whose guest Duff became on first landing in India. But this gave rise to a new squabble. Scandalised that there should be only one service on Sunday, Dr. Brown proposed to hold public worship in the evening also. Again the dispute travelled up through the usual machinery of secretaries, council and directors, when the decision came that all chaplains were military servants, but the Government would not concern itsolf with their internal ecclesiastical arrangements. Dr. Brown might act as he pleased. But he met with an unexpected obstacle at the first evening service. The precentor was engaged to raise the tune at only one weekly service, and did not appear. The good minister had a voico fortunately quite equal to the occasion, and Dr. Bryce surrendered. But in the spring of 1830 Dr. Brown had a fall from his horse, which sent him on sick leave to the Straits of Malacca, where he died, and the old state of things was re-established.

The three acts in the ecclesiastical drama of steople, cock, and second service, recall the mock-heroics on the fight of the treasurer-bishop and the chanter concerning the reading-desk of Notre Dame:- 
“ Je chante les combats, et ce Prélat terrible, Qui par ses longs travaux, et sa force invincible, Dans nne illustre Eglise exerçant son grand cœur Fit placer a la fin un Lutrin dans le chœur.

Quelle fureur, dit-il, quel aveugle caprice! Quand le dîner est prêt, vous appelle à l'office? De votre dignité soutenez mieux l'éclat, Est-ce pour travailler que vous êtes prélat?"

As Boileau closes the strife by bringing in Piety, Faith and Grace, who awaken Aristus to restore peace, so the missionary brings life back to St. Andrew's.

This was the kirk and the kirk-session under which Duff might have been bound to work, had not the young evangelist been given the foresight and the grace to stipulate that he should go out to found the mission in India fettered by no man there. The Government was distracted and disgusted, the educated natives were scandalised by this continued exhibition of Christianity, and the Scots, who had been so proud of their national kirk, ceased to enter it. Some permanently joined the Church of England, especially when the loving and cultured Reginald Heber became the second Metropolitan of India, and others found what they desired among the Congregationalists or Baptists. The majority of the residents, Scottish and English, made the Sabbath a time of pleasuring, when they could absent themselves from their offices, which were open and busy every day. Boating excursions, picnic parties to Barrackpore and the French and Dutch settlements up the river, and pig-sticking on the edge of the Soonderbun jungles to the south of the city, were the result of the spiritual energies of Middleton and Bryce.

In this state of things Dr. Bryce resolved to take furlough home. Believing that he could help the new $I=$ 
mission by reporting its success, in which he had always sympathised, he quietly proposed to throw on the missionary the whole duty of preaching in St. Andrew's pulpit and taking pastoral oversight of the large Scottish community Thus modestly and in this brotherly spirit did Duff reply to the first suggestion on the 30th November, 1831:- “I should have rejoiced to have been able to have rendered more frequent assistance on Sunday; but I really find every moment so engrossed, and the personal fatigue often so harassing from the miscellaneous calls on my daily arocations, that I have little time and generally still less strength to spare for pulpit duties. In the event, however, of your twelvemonth's trip being resolved upon, I would be ready to do my best, or to enter into the adoption of any measure which might secure regular service for the good folks of St. Andrew's. This, however, is a subject for further consideration." The next information which Duff received was in the form of a letter, sent back by the pilot from the Sandheads, as the mouth of the Hooghly is called, in which Dr. Bryce announced his sudden departure with his invalid wife. With no stock of prepared sermons (for all his manuscripts had gone down at Dassen Island), with his daily college duties, and his weekly evening lectures, the sudden call made even Alexander Duff hesitate. But having reason to believe that if the kirk were once shut Government would put difficulties in the way of opening it again, bewailing the condition of his own countrymen as sheep without a shepherd, and meeting at every turn the evil effect of their lives on the observant natives, he threw himself into the breach.

Never before - not when Kiernander was in the full flush of that activity which attracted Clive, and 
his own Cambuslang compatriot, Claudius Buchanan, was reproving even a good Governor-General like Cornwallis-had Calcutta seen such a preacher and pastor. He went into the pulpit the first Sunday to find a score of worshippers lost amid the eight hun. dred chairs. The sight he described as that of "a void and huge wilderness." The session registers gave him the names of not a few who had continued to preserve their latent rights by paying seat-rents, and with these he determined to begin. The easy theory had been that the Scotsman in India is so different a being from what he is at home, that he regarded his minister's visit as intrusive. The new pastor soon put that to the test. He found his purely pastoral calls welcomed. The Sunday solitude of the kirk gradually became a respectable crowd. The ministrations during nearly all 1832 resulted in the creation of the good congregation which Dr. Charles, the new chaplain, found on his arrival. The results on the morals and the higher life of European society became marked. Bishop Turner, who followed Dr. James, the short-lived successor of Heber, had been grievously vexed by the utter absence of all signs of a day of rest, Christian or national, when he landed. Government as well mercantile offices were open daily without intermission, as they had been since the first settlement of the British in India. The bishop's attempt to reform society by privately asking the less godless to sign a voluntary pledge to abstain from business and from compelling the natives to attend office on the Lord's-day, brought down on him the fiercest bigotry and intolerance. Duff, a little later, found his opportunity just before Daniel Wilson landed as the next bishop.

A prosperous young Scottish merchant asked the officiating minister of St. Andrew's to baptize his first. 
born. The father was met by a kindly exposition of Presbyterian discipline, and was recommended to delay until he himself should, by attending church at least, and then by observing family worship, show some honest regard for the Christianity he professed in name only. Resentment, under Duff's persuasive kindliness, soon gave way to the confession that he was junior partner of a firm which employed five hundred natives, that his senior was in England, that he had to supervise the men on Sunday as on other days and could not possibly attend church. The minister's further intercourse with him and his wife led him to try the experiment of shutting the office for one day in seven. Summoning his operatives on the Saturday, he explained that for the next month he would not require their attendance on Sunday, but would not on that account lower their wages. If he found that the four or five holidays led them to work more zealously, he would be able to make the arrangement permanent. They could not believe the statement at first, and it soon formed the talk of the neighbourhood and of the surrounding villages to which they belonged. It was found that not one was absent on Monday morning, and that that month's tale of work exceeded the out-turn of each of its predecessors, while a new feeling of cheerful loyalty and confidence had been born between the employed and their employer. The change, and the baptism which followed, became the beginning of a new life to more than to this family. It was long till society became outwardly transformed. But that was the dawn of the social as well as spiritual improvement which has made the Christian day of rest, observed by Government order and European opinion, a boon and a teacher to the thousands of toiling Hindoos and others who rejoice in its physical advantages, and are 
sometimes led by it to higher thoughts, though, un doubtedly, the viciously inclined abuse the rest as all good gifts may be abused. The English Sabbath is not the least of the blessings conferred by the British Government on India, and, as usual, the missionaries pointed the way.

Not till he had been for six months thus building up the congregation did Mr. Duff announce the intended communion of the Lord's Supper. A young American waited upon him next day to declare that, being from Boston, he had been brought up a Unitarian, but had failed to find any real comfort in his religion. Expecting an impulse to a higher emotional life at least from the celebration of the sacrament after the simple Scottish form, he sought permission to sit down at the table with friends who were alrearly members of the Kirk. Having expounded the true nature of the divinity of Jesus Christ, very much as he had done to inquirers like Krishna Mohun Banerjea, and pointed to the only source of all the privilege of His memorial sacrifice, Mr. Duff recommended further study of Scripture. The youth consented, and at the same time courteously offered his counsellor the books of Dr. Channing, which were at that time new to England and India. As the American, with the assistance of no little intercourse with Duff, was gradually being led upwards from Jesus of Nazareth to the Immanuel Who was wounded for our transgressions, a wasting sickness seized him, and he was sent to sea to the health-giving breezes at the Sandheads. In the pilot-brig he died, but not before the full glory of the Incarnation entered his soul, and he charged the captain, as he died, to tell Mr. Duff that he had found Jesus to be his all-sufficient because Divine Saviour. Such cases may be taken as typical of the work done among his own people in that year 
memorable to many. Thus, as ever after, there worked side by side in Duff's career the evangelising of the Hindoo and the recalling by the evangel of many who had forgotten their baptismal, their national, their personal birthright in Christ.

In all this the impulsive but ever loving heart of Alexander Duff had continued to pant for the sympathy of such a friend as Urquhart, whom he had lost all too soon in his student days. Dr. Brown had been taken away, and in the great-hearted Swiss Lacroix, over whose grave he long after poured out a eulogy worthy of David and Jonathan, he found some of the affection that strong men cherish. Many, who knew little of the far higher work he was doing for all time, had desired to see him Dr. Brown's successor, and to this he alludes in these letters to the Rev. Dr. Laurie, the Madras chaplain, by whom he had been hospitably received on his way to Calcutta. The fervour of his friendly longing bursts forth, as it ever did to those he valued. Here, too, we see his interest in the soldiers, for whom few then cared :-

\section{"College Square, Calcutta, 1st Nov., 1830.}

"My Dear Friend,-Bold indeed must that heart be, and cheerless that soul, that would not experience, I will not say pleasure simply, but strong emotions of holy love and ardour on the perusal of your truly apostolic letter. I have not for a long time received anything so refreshing and to myself so humbling. With the sincerity of conviction I felt that you treated me and mine with more than a brother's kindness, and manifested towards me more than the natural tokens of a brother's love, and I appeared to feel that it was not possible to regard any other brother in Christ with a more tender affection. But since the receipt of your last letter you seem as if more endeared than 
ever to my soul. Such warmth, such earnest anxiety, such bowels of compassion, such yearnings of a father for the souls of his people! Truly was I cheered and aroused, as with a message from heaven, and humbled to the very dust. $\mathrm{Ob}$, that I had one half the zeal and anxious longing for the redemption of lost souls and the continued welfare of such as appear to be within the fold of Christ! Oh pray with me, and for me, that all the cold and frozen apathy of nature may disappear before the genial influences of a heavenly fire!

"It need scarcely be added, that immediately after receiving your letter the necessary inquiries were made respecting the regiment in behalf of which you expressed such deep and unfeigned interest. The information obtained was that one half of the regiment had reached Calcutta, and proceeded straight on to Chinsurah, thirty miles to the north ; that Chinsurah itself was only to be a temporary station, as the intention was that they should proceed without delay to the upper provinces. By this arrangement I am not only deprived of the opportunity of being useful to them, but also precluded from the possibility of seeing them at all. I trust, however, that they will not be forsaken, that $\mathrm{He}$ who hath begun a good work will accomplish it unto the end. While at Chinsurah they may derive benefit from the instructions of Mr. Pearson, missionary of the London Society. On Monday last week he came down to Calcutta on business: to him I represented the case as strongly as possible. He felt for them, and stated that on Sunday, 24th October, about forty assembled and listened attentively to his address; and that his efforts should not be spared so far as his other duties would admit of it. Hence you perceive that the Lord has dealt very graciously with them; and our prayers should be that 
at every station some man of God may be raised up to comfort and cheer this little band in the perilous voyage to eternity, warn them of danger, strengthen them for the toil of a busy warfare, and direct them in safety to the blissful haven of eternal rest.

"It is interesting to think that after reaching Calcutta the idea suggested in your letter, of employing pious and respectably educated soldiers as teachers, occurred so forcibly to my mind that the first attempt to secure teachers was directed to that quarter; and it was only after the attempt proved fruitless that my attention was particularly directed towards 'the country-born,' as they are commonly called. Among these, after much trouble, anxiety and waste of time, I succeeded in securing two or three young men of apparent piety and steady consistency of conduct. For this I feel thankful to God, and trust that in future, with God's blessing, the requisite supply of subordinate teachers may be had from this class.

"I would now be inclined to give you some account of all my proceedings for the last five busy busy months, but know not where to begin or how to end, so multifarious and closely crowded are the materials accumulated. A volume, not a few sheets, would be required. This note, however, is but the preliminary notice, as it were, of what I trust will be a frequent and delightful correspondence. In order to meet your wishes, when you write be so kind as to state, in the form of question, those subjects on which you would desire to be informed, and $I$ in return will take the same liberty with you. I have now traversed every part of Calcutta and its vicinity; have resolved, after much anxious inquiry, to make Calcutta my headquarters; have found the impossibility of instituting, in the first instance, a central seminary of the de- 
scription proposed by the Assembly's committee; bave found, after much investigation, that, in the present state of things in Calcutta, it is more advisable for the Assembly's ultimate purpose to maintain English in preference to Bengalee schools; have proved, by a most successful experiment on a large scale, that, with proper management, elementary English education, including the reading of the Scriptures by the most advanced classes, may be carried on to almost any extent; and that, in the course of a very few years indeed, a central institution for a higher education will be absolutely demanded. I cannot enter into detail. In the school now formed in the building formerly occupied as a Hindoo college, on the Chitpore road, there are present every day, after making the necessary allowance for temporary engagements and sickness, not less than 250 from the age of six to twentyfour, and of all classes from the Brahman downwards. The labours of every day are commenced with prayer - generally the Lord's Prayer, as that has been fully explained; about ninety read a portion of the New Testament in English, and listen to any explanations or remarks. So far well. The Lord alone can give the effectual blessing. I have been and still am in a whirling vortex of employment. Excuse therefore my haste. Pray write me without delay. Remember me in kindness to those dear friends who share in our Christian affection - Messrs. Dalmahoy, Bannister, Mr. and Mrs. Wardrope, Mr. and Mrs. Webster, Mr. Smith and Mr. Ridsdale. I have no recollection of one of the name of Rodgers at St. Andrews. I pray fervently with my whole heart that he may prove a faithful, zealous and devoted fellow-worker with you in the ministry. $\mathrm{Oh}$, who can estimate the blessing of a messenger of God, having the same mind and bearing the shame with and for Christ! Who can 
estimate the curse of an emissary of Satan, wearing the outward garb and glorying only in the riches of Christ's visible Church! The last accounts from Dr. Brown are cheerless; I fear he is no more; if so, happy, happy, happy he!"

“29th December, 1831.

"Things here are in a very complicated state, and very difficult to unravel in all that concerns the vitals of religion, whether among Europeans or natives. I think it not unlikely that when a decided movement sball take place it will be simultaneous among all classes, and probably sudden in its appearance. $\mathrm{Be}$ this as it may, the elements of change are at present accumulating rather than any great or decisive change developed. Much is visible to call forth gratitude to God, but nothing, nothing to equal the expectations raised at home or justify the gloryings of many.

"I am still little else than an explorer of the field, thongh the success of the large English school established is pleasing, and with the Divine blessing it may become one of the nurseries of a higher and better institution. Since the departure and death of our mutually much esteemed friend, Dr. Brown, I am left absolutely alone. Many, many are exceedingly kind and friendly, but there is not one who can feel and co-operate with me as a brother. Often I think of Madras and of the kind friends there, and especially of you, my brother. More I cannot say-I always fear giving vent to my feelings, lest there might escape a word that indicated repining or dissatisfaction with the allotments of the Almighty.

"My spare time-and it has hitherto been very limited-is devoted to the languages. Here, with God's blessing, I experience little difficulty-the want 
of time is my grand enemy. I have had no tidings from home of late, though I daily expect to hear something about fellow-labourers on their way or arriving. Education can be pursued to almost any extent in Calcutta, with proper agents and adequate funds. I intend very soon to transmit home a report or memorial on the practicability and necessity of founding an institution for the more advanced branches of a literary, scientific and Christian course of instruction, to which the labours of European teachers shall be chiefly confined, while the branch schools may always be conducted by less qualified individuals to be found already in the country, and the direct preaching of the gospel shall be carried on to the utmost practicable extent.

"Has your colleague arrived? and does he profess a kindred spirit? Many here have wished to persuade me to apply, or allow application to be made, that I might succeed Dr. Brown, but I have peremptorily declined, on the ground that my motives might be misrepresented and misconstrued-that the act might be viewed as an inglorious abandonment of the cause which I have engaged to promote, and that in this way the cause itself, so far as its present connection with the Church of Scotland is concerned, might languish and suffer. But from my soul I pray, and I am sure you will join me in this prayer, that a man of God may appear to heal the breaches that have been opened in our Zion.

"Have you written Dr. Inglis? or found it prudent to attempt making any collection for the General Assembly's fund? Yours very truly,

\section{"Alexander Duff."}

Daniel Wilson's arrival in 1832, as fifth Bishop of Calcutta, brought together two men of the same 
evangelical spirit though separated by ecclesiastical forms. "A visit to Dr. Carey at Serampore," writes the bishop's biographer, "elicited many interesting reminiscences of the early Christianity of India. A friendly conversation with Dr. Duff furnished important information on the subject of native education." Daniel Wilson's episcopate was to last nearly as long as Duff's apostleship in India. Although the most "churchy" of evangelicals the bishop wrote of Lord W. Bentinck, as he might have done of Duff, "Lord William is rather more of a Whig and less of a churchman than I could desire, but incomparably better than the highest churchman if without piety, vigour and activity. Lord William reverences religion and its sincere professors and ministers, but he has prejudices against bishops." Like Duff, the Governor-General had told the new bishop, who applied to him in vain to have his sacerdotal claims over the chaplains legally acknowledged, "Christianity is my object." The bishop rejoined with characteristic prejudice: "With a feeble people like the Hindoos there must be creeds, a liturgy and an established ministry." Yet Duff had won his first four converts there, and the revolution he had begun was so fermenting that the bishop wrote in March, 1833: "A most interesting moment is dawning on India. The native mind is at work. A beginning of things is already made."

Europeans and Americans constituted only one-half of the professing Christian or born Christian community in India. Before the influence of missionaries and chaplains, the overland route and liberal furlough rules combined to make the married life of white settlers in India all that the wife of Sir Henry Lawrence longed for it to be, in the Calcutta Review, the Eurasians (Europe-Asia) or East Indians had become 
strong in numbers, the offspring of English fathers and native mothers. In 1833 Duff developed into a system his labours for them.

Leaving out the half-caste children of the earlier Portuguese, who had been allowed to fall near the level of the lower castes by the Romish Church which should have cared for its sons, the mixed offspring of their officers and writers early forced the Company to attend to them. So far as these children had sprung from soldiers, the Military Orphan School, for whicb David Brown first went to India, was established in 1783, and the Female Orphan Asylum in 1815-noble charities still. In 1789 the charity school for others was developed into the Free School, originally endowed with part of the compensation paid by the Moorshedabad Government for its sack of old Calcutta. The immortal three of Serampore established the Benevolent Institution in Calcutta to meet the increasing need, while Dr. and Mrs. Marshman conducted ligh-class schools at Serampore for the benefit of the mission. More recently the third of a million sterling, left by the Frenchman, Claude Martin, who "came to India a private so'dier and died a major-general," as his tomb records, was spent in Martinières or boarding schools for poor Christians in Calcutta, Lucknow, and his native city of Lyons. Finally, the great and good Henry Lawrence endowed the hill Asylums which bear his name, for the children of our Christian soidiers not otherwise provided for. It is a bright roll of Christlike love covering a multitude of sins, not judging, but healing and atoning for an evil and, to its victims, inevitable past.

Now in all this there is no independent self-effort. The Eurasian community has given India and England some of its best men and women, whose virtues were nursed on self-i'eliance and the fear of God. In 
1823 the Eurasians of Calcutta united to found a joint proprietary school, catholic within the limits of Protestantism, for the higher education of their children. Their fine ideal they somewhat stiffy expressed in the name they gave to what became the germ of the Doveton Colleges, the Parental Academic Institution. In this they followed the Baptist founders of the Benevolent Institution and the Armenian conductors of the Philanthropic Institution, under that good man and scholar, Johannes Avdall. Their leader was the son of an English ensign who fell at the siege of Seringapatam, John William Ricketts. He rose from the Military Orphan School, through the East India Company's establishment at Bencoolen, to be the first of his class in India. This college was the boon he left them, as well as the right of sitting on juries side by side with their fellow Christians. But he did more. He deserves to be remembered as the one citizen of Calcutta who, when a public meeting was about unanimously to vote a complimentary address to the Honble. Mr. Adam, protested against so honouring the man who had stripped the press in India of liberty.

We have seen how Duff had been led, in his early despair of finding assistants, to think of soldiers, and how he had secured the young adventurer, Clift. His experience of the two lads Sunder and Pereira, who were his first pupil-teachers, and the zeal which led him to examine and advise all the schools in and around Calcutta of every kind, brought him into close relations with the collegiate school of the Eurasians. His great services to it led the managers to nominate him visitor, side by side with the patron, Lord Metcalfe, of whose merits as a Christian statesman this is not the least, that he was the first official to help the Eurasians to help themselves, as Lord Northbrook's 
Government did long after, when alarmed at the increase of Christian poverty in India caused by the thoughtless neglect of all the intervening administrations. "Much as has been gained," he told the committee, teachers and youth of the school after the tenth successful examination in 1833 : " much yet remains to be won. Let this community rise by its own endeavours ; unless men act as men, what can Governments do? Moral and intellectual knowledge are not separated, and we gain the highest dignity of our nature when we cultivate both."

For the Eurasians as for the Native Christians and all who were not either Hindoos, Muhammadans or European British-born subjects, Duff was in the front of those who fought the battle for the rights of conscience, which Lord William Bentinck partially and Lord Dalhousie and Lord Lawrence long after completely secured to all classes. With a true tolerance, but in ignorance of what it involved, Warren Hastings in his code of 1772 guaranteed to Hindoos and Muhammadans their own laws of inheritance. But these laws exclude dissidents from their respective religions from all civil right to ancestral property. Conversion meant disinheritance, and Parliament, with ignorance equal to that of Hastings, wrote such a law on the English statute-book. As if this were not enough, the East India Company had by legislation excluded all converts from public office of any kind. Duff had not been long in Calcutta when he aroke to the enormity of enactments which Muhammadans themselves would never have passed or enforced, and which fossilized Hindooism for ever. From 1830 the missionaries all over India agitated the question, the Court of Directors was stirred up by memorial, and the Eurasians sent home Mr. Ricketts to petition Parliament, which examined him. The result was the 
Regulation of 1822, which provides that no one shall lose any rights or property, or deprive any other of rights or property by changing his religion. Lord William Bentinck had previously thrown open the public service to all the natives of India, including the outlawed Native Christians, enacting that there should be no exclusion from office on account of caste, creed or nation. The development of an enlightened legislation under Macaulay, Peacock, Maine and Stephen, has now given the varied creeds and races of India better codes than any country possesses, and, save as to the rights of minors and age of majoritynot yet settled in England-nothing more is needed.

But how desirable that is still may appear from the first collision with the law, or rather the lawyers, in defence of the rights of conscience. The missionaries were those of the Church of England, their natural defender was the newly arrived Bishop Wilson, but their actual leader was the young Highlander, whose zeal for fair-play and civil and religious liberty led him alone into the breach and to victory.

The case occurred just after the whole Missionary Conference had publicly answered a thoughtless attack upon them by the then rising orientalist, H. H. Wilson, and had forced that keen Hindooizer to apologise to them. From the day when, in 1808, Wilson reported his aprival at Calcutta a young assistant surgeon, he became popular as an amateur actor and musician in the local theatre, and as a most versatile and accomplished member of society. But he worked hard at Sanscrit in the midst of all his amusements, so that in five years he published his first translation, that of Kalidasa's Meghaduta or "Cloud Messenger," and in six more his great Sanscrit-English dictionary appeared. He gradually rstablished his reputation as, next to Colebrooke, the 
greatest of English orientalists. Just before he went home, in 1832, to be the first Boden professor of Sanscrit in Oxford, an appointment which he gained by the narrow majority of seven over the learned and devout Dr. Mill, he wrote a letter on the study of Sanscrit literature in England, at the request of Bishop Turner. In that letter this passage occurred: "In Bengal the better order of Hindoos regard the missionaries with feelings of inveterate animosity, whilst they invariably express a high respect for clergymen of the Established Church. They cannot avoid seeing that the latter are held in higher estimation by the European society, and that they cannot be reproached with practices which not unfrequently degrade the missionary character in the eyes of the natives." Calied to account for this "snobbish" as well as libellous statement by "the missionaries of all denominations in Calcutta," Dr. H. H. Wilson explained that the letter was private and had not been published by him, and that he was exceedingly sorry to learn it "should have given pain to the missionaries of Calcutta, for whom generally I have a high respect, and with several of whom I have long been and hope long to be on terms of kind and friendly intercourse." His defence on the merits was, that he merely reported the opinions of high caste Bengalee society, which he did not share. This made it the more important that the missionaries should meet the reflections upon them, which they did in a letter signed by the Rer. C. Gogerly, the Conference secretary, and full of historical interest to all who would trace the development of Christianity in India.*

The truth is, that Dr. H. H. Wilson only too accurately, because undesignedly and without malice,

- Calcutta Christian Observer for Oct., 1832, vol. i., p. 233. 
expressed the contempt with which missionaries had been regarded by men and ministers of the world, in the days of the vile treatment of Carey and his colleagues by their home committee, which tempted the sneers of Sydney Smith in the Edinburgh Review. For men to live in poverty, and die unknown by their contemporaries, for the sake of oppressed or savage or superstition-ridden races, while really the pioneers of the Government which proscribed them and the founders of civilization and scholarship, was to be pronounced mean, weak, illiterate creatures. Alexander Duff in Eastern, as John Wilson in Western India, was the first to change all that, even before the gentle Carey's death, alike by his work and by such an exposure of the calumny that the boldest scoffer dared not repeat the lie.

It happened thus. Duff's success had led the Church Missionary Society to open an English school in its Amherst-street mission-house. Of that Duff's second convert, Krishna Mohun Banerjea, had been appointed master. There Brijonath Ghose, after several months' instruction, sought baptism, and took refuge with his own countryman, the master, to escape the persecution of his family. He was above fourteen years of age, then believed to be the Hindoo age of discretion, as it is more than that of puberty and marriage. Blackstone lays it down that a boy "at fourteen is at years of discretion, and therefore may consent or disagree to marriage." The father had taken the youth from the Hindoo College, lest the purely secular education there should make him a "nastik" or atheist, and had placed him under so well-known a Christian convert as Krishna Mohun, after hearing the bishop declare that instruction in Christianity was the grand object of the school. Yet, under a writ of habeas corpus, to which Krishna Mohun 
replied that the boy was not in his custody, Brijonath himself appeared at the bar of the Supreme Court. After pleadings on both sides, it was decided that he must be delivered up to his father as not of age, being only "fourteen years or thereabouts." Documentary evidence of age, from the horoscope, is fabricated in India with an ease which has led the civil service commissioners in England to reject it altogether, while oral witnesses can be purchased at sixpence a head. The test of discretion, of intelligence, of sincerity, seems to have been rejected, as it never was in England in cases which were then frequent in Chancery as to Protestant, Roman Catholic, and Jewish minors. The daily papers, by no means prejudiced in favour of men at whose puritanism they were too ready to laugh, described the scene at this the first attempt to vindicate for the natives themselves, who will one day be grateful for the act, the rights of conscience. "The poor fellow," reported the Bengal Hurkäru, " was then seized hold of by the father, who could not get him out of the court without considerable exertion. The little fellow cried most bitterly, repeated his appeals to the judges, seized hold of the barristers' table, and was dragged inch by inch out of the court, amidst the sympathy of some and the triumph of others." Bishop Wilson, who was to have baptized him, felt "lively grief ;" but he contented himself with this remark, "A free agent I really believe that boy was; and the law of deliverance has been to him and still is an imprisonment." In three years thereafter, when the most intolerant could no longer doubt his age, the youth, earnest and consistent amid all the persecution, was with three others baptized.

The father's counsel was Mr. Longueville Clark, who had then been ten years at the Calcutta bar, and continued there for nearly forty more, with the repu. 
tation of being one of the best chess-players in the world. To the legitimate arts br which he served his client, he added in open court the statement which, under other circumstances and as afterwards intensified, might have been libellous, that "this was a case of great importance, as the rights of Hindoo parents were too often invaded by the missionaries in Calcutta!" Brijonath's was the first case of the kind; it involved great legal as well as moral principles, certain to be again questioned; and the charge was repeated against the whole body of missionaries not many months after they had received a courteous a pology from Dr. H. H. Wilson. After in vain appealing to the most experienced agents of the missionary societies to vindicate the common purity of motive, rectitude of action and inevitable sense of duty, Mr. Duff, the youngest among them, entered the lists. Having failed to obtain from Mr. Clark the most microscopic evidence of his statement beyond general assertions, which added to the injury the insult that the conduct of the missionaries was "flagitious and dangerous," Mr. Duff resolved to publish the correspondence.

But where? The three daily papers he believed to be hostile to him at that time. Fortunately, Mr. Stocqueler, also of the Sans Souci theatre set of amateurs, had come round from Bombay to Calcutta, and had bought the Tory newspaper of Dr. Bryce, the John Bull. Securing as his staff of heavy writers Sir John Peter Grant, who had resigned the Bombay bench after his squabbles with Sir John Malcolm, Mr. John Farley Leith, now M.P. for Aberdeen, and Mr. Charles Thackeray, uncle of the great prose satirist, the new editor converted the almost defunct daily into the liberal Englishman. At that press Macaulay used soon after to print the rough proofs of those essays which he 
sent from India to Napier, while Holwell's monument to the memory of those who died in the Black Hole still perpetuated the humiliation, and Plassey looked as it had done on that morning of sunshine breaking through the rain-clouds when Clive gave the order to cross the river. Mr. Duff found the new editor willing to look at the correspondence, though alarmed by its bulk, and was surprised to find the whole in next morning's paper, introduced by fair and even bold editorial remarks. The case is only another illustration of that marvellous power of persuasion which, resting always on a good cause, made Duff irresistible, even by experts like himself, in private discussion still more than in his most skilful and eloquent orations. We remember a later case, in which, in the more judicial Friend of India, one who has since proved the most brilliant of English journalists, having advocated one side of a question, was led by the moral suasion and logical power of Duff, directed by a spirit of purest philanthropy, to confess that he was wrong, frankly stated the other side, convinced the Government, and altered the proposed action.

Never, in all the controversies which we have read or heard, have first thoughtless misrepresentation and then deliberate malice received such a castigation. There are passages in the twenty octavo pages of Duff's alternate scorn and ridicule, reasoned demonstration and rhetorical appeal, of which Junius would have been worthy if that pitiless foe had fought with sacred weapons and for other than self-seeking ends. The Christian is never forgotten, for it is the rights of conscience and the supremacy of truth for which he fights. Nor is the man, the Celt, the indignant defender of the honour of his colleagues, of the glory of his Master in them, and of the grandeur of their one mission, wanting. The reply of the barrister was the 
mocking laugh of Mephistopheles, the expression of a desire to secure the missionary "for our Calcutta Drury." The press and all society were disgusted or indignant at the lawyer assailant, to whom was applied the couplet from Young's Epistle to Pope :-

" He rams his quill with scandal and with scoff, But 'tis so very foul it won't go off."'

The episode closed, for ever, the period of supercilious contempt and intolerant misrepresentation of men and of a cause soon found to be identified with the best interests of the Hindoos themselves as well as of the British Government. The defeated barrister expressed the desire of seeking the satisfaction appropriate to himself, in a challenge to fight a duel, which only the black coat of the defender of the faith prevented him from sending. But he went so far as to consult a friend on the subject.

All the local honours and attentions which Calcutta society could at that time offer had been pressed upon Mr. Duff ever since the first examination of his school. Especially did the leading men urge him to join the Bengal Asiatic Society, although with most of them he was conducting the Oriental controversy. But duty to his daily work prevailed over his natural tastes, and the memory of Dassen Island was never absent from him in the face of what he regarded as temptations to literary self-indulgence. Of the publications, library, and other aids of the Society he made full use in the war of languages, alphabets and systems. Much more evident to him was the duty of using the Agricultural Society of India, founded by Carey for the improvement of the peasantry and the enlightenment of the great zemindars whom the permanent settlement of Lord Cornwallis had recognised as copyhold landlords on a vast scale. Of this body he was long a 
member, alike in its executive and in its publications committee, and thus he found outlets for many of the educated natives, non-Christian as well as Christian.

Of the social life of Mr. and Mrs. Duff at this period we have one significant glimpse. The accession of Williare IV. to the throne was marked by an official ball at Government House, to which they were duly invited by Lord and Lady William Bentinck. Perplexed, the Scottish missionary took counsel of a chaplain, who assured him that, viewing the invitation as a command, he was in the habit of going to Government House on such occasions, of making his bow to the Governor-General and his wife and at once retiring. This compromise did not commend itself to Mr. Duff, even although he had not remembered the memorable experience of the first Bishop of Calcutta. On the occasion of the trial of Queen Caroline, a witness for the defence attempted to justify her presence at an indecent dance by the assurance that he had seen Bishop Middleton and his family at a nautch in Government House. A reference made to Calcutta elicited the fact that Dr. Middleton's family were present but not himself ; and the Marquis of Hastings sent the explanation to the Lord Chancellor that the movement of a woman's feet while she sings cannot be called dancing. This, however, was not a nautch, but an official ball for Europeans only, such as that from which, at a later period, Lord Elgin carefully excluded native nobles, who were liable to misunderstand the motives of English ladies on these occasions. Mr. Duff frankly stated, in a letter to the private secretary, the reasons why he could not conscientiously obey the most kind and courteous command of the ruler of India. After long delay he received the GovernorGeneral's cordial approval of his spirit and action. 
Soon after his Excellency begged the missionary and his wife to meet him at dinner in one of those frequent gatherings where the two men discussed, in a like spirit, the highest good of the people and the government of India.

Lord William Bentinck left India after sickness had driven Duff home for a time. He was a statesman and a philanthropist worthy to be associated in the spiritual as well as intellectual reformation of India with the man to whom, in his absence and when bidding all the missionaries good-bye, he made this reference, after answering those who would use the force of the conqueror and the influence of the state-paid bishop to induce the profession of Christianity: "Being as anxious as any of these excellent persons for the diffusion of Christianity through all countries, but knowing better than they do the ground we stand upon, my humble advice to them is, Rely exclusively upon the humble, pious and learned missionary. His labours, divested of all human power, create no distrust. Encourage education with all your means. The offer of religious truth in the school of the missionary is without objection. It is or is not accepted. If it is not, the other seeds of instruction may take root and yield a rich and abundant harvest of improvement and future benefit. I would give them as an example in support of this advice, the school founded exactly upon those principles, lately superintended by the estimable Mr. Duff, that has been attended with such unparalleled success. I would say to them finally, that they could not send to India too many labourers in the vineyard like those whom I have now the gratification of addressing. Farewell. May God Almighty give you health and strength to prosecute your endeavours, and may $\mathrm{He}$ bless them with success." The deputation to whom the great pro- 
consul addressed words such as had never before been heard from a Governor-General's lips-nor sinceconsisted of the venerable Dr. Marshman, the saintly Lacroix and Mackay, Messrs. Sandys, Yates and W. Morton.

Lord William Bentinck left the land for which he had done so much, in March, 18:35, eight months after Duff, whose work he legislatively completed in the last weeks of his seven years' administration. But Duff was not driven from his position, even by almost deadly disease, until he had developed his school, with Mackay at his side, into "a complete Arts College including the thorough study of the Bible as well as the evidences and doctrines of natural and revealed religion." The annual examination of the classes in the town-hall became one of the notable events of the year, when there assembled the best representatives of all society, European and native, from the GovernorGeneral and his wife, and the learned son of the founder of the orthodox Dharma Sobha, the Raja Rhadakant Deb, to the humblest Baboo or middle-class Bengalee. Reporters, through all the newspapers, spread the facts of the six hours' testing of Hindoos in Biblical as well as secular knowledge, over Southern and Eastern Asia. Mr. Mack, the able graduate of the University of Edinburgh, whom the Serampore three had associated with them in their educational and literary labours, used to publish a critical estimate of the whole, which guided the many imitators of Duff, Christian and non-Christian, to higher efforts. We may leave with him for a time the famous General Assembly's Institution, with this description of its founder as he first appeared to a little trembling eagereyed boy brought in from the jungles of Bengal to learn English by an orthodox father, who ran the risk of afterwards seeing his son a Christian and in time 


\section{a missionary. The Rev. Lal Behari Day writes of this time:-}

"It was some day in the year 1834 that I accompanied my father to the General Assembly's Institution. It was about a month after I had been admitted into the institution that I caught a near view of the illustrious missionary. He came into the class-room while we were engaged in reading the first page of the 'First Instructor'-the first of a series of classbooks compiled by himself; and though forty-four years have elapsed since the occurrence of the incident my recollection of it is as vivid as if it had bappened only yesterday. I cannot say he walked into the class-room-he rushed into it, his movements in those days being exceedingly rapid. He was dressed all in black, and wore a beard. He scarcely stood still for a single second, but kept his feet and his hands moving incessantly, like a horse of high mettle. He seemed to have more life in him than most men. He had his white pocket-handkerchief in his hand, which he was every now and then tying round his arm and twisting into a thousand shapes. He seemed to be a living personation of perpetual motion. But what attracted my notice most was the constant shrugging of his shoulders, a habit which he afterwards left off but which he had at that time in full perfection. In our lesson there occurred the word 'ox': he took hold of that word and catechised us on it for about half an hour. He asked us (the master interpreting his English to us in Bengalee) whether we had seen an ox, how many legs it had, whether it had any hands, whether it had any tails, to the infinite entertainment of us all. From the ox he passed on to the cow, and asked us of what use the animal was. The reader may rest assured that he did not speak before Hindoo boys of the use made of the ${ }^{\circ}$ flesh of the cow, bnt dwelt chiefly on milk, cream and curds. He ended, however, with a moral lesson. He knew that the word for a cow in Bengalee was goroo, and he asked us whether we knew another Bengalee word which was very like it in sound. A sharp class-fellow quickly said that he knew its paronym and that it was gooroo, which in Bengalee means the

- Recollections of Alexander Duff, D.D., LL.D., and of the Mission College which he founded in Calcutta. 1879. 
Brahman spiritual guide. He was quite delighted at the boy's discovery, and asked us of what use the gooroo was, and whether, on the whole, the goroo was not more useful than the gooroo. $\mathrm{He}$ then left our class and went into another, leaving in our minds seeds of future thought and reflection."

To his own college teaching and such school supervision Mr. Duff added a constant attention to the aggressive work of the Bengal auxiliary of the British and Foreign Bible Society and of the Religious Tract and Book Society. His Sunday evenings were given up in 1833-34, to a new course of lectures and discussions, contrasting Christianity with Hindooism and Muhammadanism. For these public controversies he purchased an excellent bungalow in the native city, at a point where four main thoroughfares met. Night after night for a long time eager inquirers, earnest disputants and curious spectators crowded the place almost to suffocation. Every year was ad ling to the intelligence of the native public, the purely spiritual and moral suasion of Christianity was coming to be understood, and this last course proved the most popular of all. Even Muhammadans attended and took part in the grave quest after divine truth, and the crowds spread the story not only over the city but into many a rural village where the Christian missionary had not been seen.

But what of the man himself who, for four years, did not cease to burn thus lavishly and incessantly the physical energy he had brought from the Scottish Grampians, the exhaustless enthusiasm he ever fed at its heavenly source? He had received his first warning in the great cyclone of May, 1833, but heeded it not. Prematurely came the rain that year, marshalled by the rotary hurricane which, revolving within itself, as if the destroying counterpart of the harmony of the spheres, moved rapidly over the land. From the Bay 
of Bengal, the mighty waters of which it dragged in its devastating train, over island and mainland, forest and field, village and town, the wild fury of the cyclone rolled itself north and west. Here the storm-wave and the wind bore inland for miles to some rising ground a full freighted Indiaman of 1500 tons, among the hamlets of the peasantry, where for months after it lay a marvel to all. There it swept into sometimes instant but more frequently lingering death hundreds of thousands of human beings and their cattle, whose vain struggles to cling to roofs and trees and the floating wreck of their desolated homes suggested thoughts of a greater flood and prayers for the bow of mercy. Most graphic of all was this incident, which we tell as Duff himself told it to the writer. His authority was the Argyllshire fellow-countryman who, on that dreadful day, was superintending the clearing of the jungle on Saugar Island.

For several weeks before his party had been annoyed by the night attacks of a tiger of unusual size and ferocity. It carried away some of their animals employed in agricultural operations, as well as two or three human beings. When the cyclone prevailed and the water continued to rise over the island, as many natives as could swim went to the Scotsman's bungalow for shelter, until it was greatly overcrowded. At last, while watching the flood rapidly rising to a level with the floor, at a distance, driven before the tempest along the mighty torrent of waters, he noticed the famous tiger evidently aiming at reaching the house. Happily he had a double-barrelled gun loaded and ready. The tiger reached the bungalow, laid hold of it, leaped into it, worked a way trembling through the dense mass of human beings, and did not stop till he got head and nose into the remotest corner, where he continued to lie still quiver- 
ing like an aspen leaf. The Scotsman concluded that though, under the influence of terror produced by the violence of the tempest, he was then quite tame, if the bungalow escaped and the storm abated the genuine nature of the savage brute would return, and all the more speedily from the exhaustion it must have undergone swimming and struggling to reach the bungalow. So he very coolly took the gun and pointed the barrel to the heart, rest. ing it on the skin, which he afterwards showed to all Calcutta as a trophy of that cyclone. Thus mingled were the terrors of the tempest, which has often since recurred, and on the last occasion, in 1876, even more horribly.

The effect on the survivors was for a time quite as deadly. Many who escaped the flood fell by the pestilence which it brought when the waters subsided and the cold season of 1833-34 came round. Malarious fever, bred by the rotting carcases and vegetation, spread a blight over the fairest portions of the rice land. Inexperienced in tropical sanitation, and bound to discharge the duty of inspecting the prosperous branch school at Takee, Mr. Duff, his family with him, set off by native boat for the place, which is seventy miles due east of Calcutta. It was November, and the country was only beginning to dry up. Scarcely had they left the city when they came upon a mass of putrid bodies, human and animal, through which they had to work their way. All was beautiful to look at in the green jungle forests of the Soonderbuns, but the abundant fruit from which the Bengalees take their proverbial word for "hypocrite" symbolised the reality. Mr. Duff plucked the tempting rakhalee only to find it filled with nauseous slime. Mr. Barlow, son of Sir George Barlow who had been interim Governor-General, was in charge of the Com. 
pany's salt station of Takee on $£ 8,000$ a year. Dr. and Mrs. Temple received the missionary and his party with their usual hospitality. The return journey, by palankeen, was even worse, and the missionary was laid low by his first illness, jungle ferer in its deadliest form. His fine constitution showed that robust elasticity which often afterwards resulted in rapid recovery, and after tossing amid the sea breezes of the Sand. heads for two or three weeks he was once more in the midst of his loved work. But with the heat of April, 1834, a remittent fever came on which his vigour of will resisted so far as to take him, again and in that weather, to Takee. Dr. Temple, alarmed at his appearance, at once sent him back, warning him against the scourge which, even more than cholera still, was then the opprobrium medicorum-dysentery.

On his return at the height of the hot season he found as his guest the good Anthony Groves, surgeon-dentist of Exeter, who gave up all he had for a mission to Baghdad, and was the first and best of the Plymouth Brethren. The romantic and very pathetic story of that mission to Muhammadans under a Government which punished apostasy with death, the experience of Francis W. Newman and Mr. Parnell and the young Kitto-this is not the place to tell, as Groves told it in the sympathising and sometimes amused ear of Alexander Duff in 4, Wellington Square, Calcutta. For when the two widowers, Groves and Parnell, and the young bachelor, Newman, left Baghdad, they could not leave behind them their one convert, the lovely Armenian widow of Shiraz, Khatoon, nor could she travel with them save as the wife of one of them. So they cast lots, and the lot fell on John Vesey Parnell, graduate of Edinburgh University ; and when he succeeded his father, the first Baron, in 1842 she became Lady Congleton. So we have seen more 
recently, but according to their regular custom, the lot fall on the Moravian who, having descended from the snowy solitudes of Himalayan Lahoul to receive the brides sent out by the followers of Zinzendorf, married one and conducted the others to his expectant brethren. Duff must have smiled when his guest, of high, even childlike spirituality, gravely told him how when Parnell had invited the British Resident at Baghdad and the European assistants to dinner, he applied Luke xiv. 13 literally by calling in some fifty of the poor, the maimed, the lame and the blind to share the feast.

Having come round by Bombay and Tinnevelly, where he renewed an old friendship with Mr. Rhenius, and was charmed by the primitive simplicity of the native church there, as Bishop Cotton was thirty years after, Mr. Groves found himself in a new world when among the young Brahmans who were searching the Scriptures diligently. After a general survey of the whole school and college he was closeted with the highest class, and left to examine them on the Bible, on theology, and in detail on the evidences of Christianity. Himself an excellent scholar, Mr. Groves was astonished at the intelligence and promptitude of the replies. But the whole force of his loving nature was drawn out when he came to examine these Hindoos on the design and effect of the sacrifice of the Son of God on the Cross of Calvary. His questioning burst forth into an appeal which pressed home on their conscience the knowledge they had shown, while he wept in his fervour, and the eyes of the young men glowed with reflected inspiration. Then turning suddenly to Mr. Duff he exclained, "This is what I have been in quest of ever since I left old England. At Baghdad I almost daily exhorted the adult natives, but in the case of even the most attentive I always painfully felt there was a crust between their mind and mine. Here 
I feel that every word is finding its way within. I could empty the whole of my own soul into theirs. How is this?" Duff's answer was to open the door into the large hall and point to the busy scene, to the children in the infant gallery lisping the English alphabet. "There," he said, "is the explanation. Well do I remember how I would have loathed such employment, not only as insufferably dull, but as beneath the dignity of the clerical office. But on coming here I soon found that this, with a specific view to the systematic attainment of higher ends, was inperatively demanded as auxiliary to the ultimate renovation of India. On the principle of becoming all things to all men and new things in new circumstances, there four years ago did I teach A B C. Pilloried though I was at the time, in the scorn of some, the pity of others, and the wonder of all, the work was persevered in. And you have seen some of the fruits. The processes that followed the alphabetical training tended in a gradual and piecemeal way to break up and remove that very crust which interposed an impassable barrier between your instruction and the minds of your auditors. Was it not worth while to begin so low in order to end so high ?" "Indeed," replied Groves, "this throws new light on the whole subject. I frankly confess I left England an avowed enemy to education in connection with missions; but I now tell you as frankly that henceforth, from what I have seen to-day, I am its friend and advocate."

That was Duff's last day, for a long time, in his loved Institution. Even then the agony of dysentery had begun, and its prostration, more terrible mentally than physically, soon followed. A generation was to pass before the specific of ipecacuanha was to be used to charm away the bloody flux which used to sweep off thousands of our white soldiers.- Four physicians 
failed to heal the visibly dying missionary. The good Simon Nicolson, the Abercrombie of Bengal, had just been succeeded by Dr. now Sir Ranald Martin, him. self now followed by Sir Joseph Fayrer. Ranald Martin was called in, pronounced the case desperate, but asked permission to try an experimental remedy which had saved one or two of his patients. The result was that, after a long and profound trance as it seemed to the sufferer, he woke up to consciousness, to revival, to such a point of convalescence that he could be carried on board the first Cape ship for home. The devoted Groves had slept beside him day and night, nursing him with a brother's tenderness. For he was not the only invalid. On the day that the stricken family were laid in their berths in the John M'Lellan, bound for Greenock, with Groves as their fellow-passenger, a son was born, to whom the name of Groves, as well as his father's name was given. From Mrs. Duff's letter communicating the departure to Dr. Chalmers we learn that, even when thus rescued from the very gates of death, the ardent missionary implored the doctors to send hi:n on a brief voyage short of Great Britain. "I devoted myself to the Lord," he pleaded, "to spend and be spent in His service in this land." Ranald Martin's stern reply was: "In the last nine months you have suffered more from tropical disease than many who have passed their lives in India. Let not a day be lost." As the Greenock Indiaman dropped down the Hooghly his boy was taken to comfort him. But he would have been still more cheered had he known that at that very time, in July, 1834, his old friend, David Ewart, was being ordained as the third missionary of the Church of Scotland and would soon after arrive to help Mr. W. S. Mackay.

Thus closed the first five years since Duff had been sent forth from St. George's, with the charge of 
Thomas Chalmers ringing in his ears, ordained to preach the gospel in India. Thus ended the first period of his Indian service since he opened his famous Institution in the great Bengalee thoroughfare of Chitpore road, Calcutta. Even the half-century which has passed since Inglis planned and Chalmers preached and Duff responded, "Here am I, send me," enables us to say that that lustrum is entitled to rank with the most memorable eras when human progress has taken a new start to the enlightening and the blessing of a whole continent. As the missionary is borne to the life-giving breezes of ocean from the sweltering pestilence of a Bengal July, the precious seed he has been sent to sow is germinating and growing up night and day, he knoweth not how. 


\section{CHAPTER X.}

\section{5.}

\section{THE INPALID AND THE ORATOR.}

Unwillingness to leave India.-The Voyage Home.-The Reform Election and Sir Robert Peel.-Welcome from Dr. Chalmers.Ignorance of the Committee after death of Dr. Inglis.-First Addresses.-Comes to an understanding with the Committee.Confidential Notes on the Four Converts.-Letter from Gopeenath Nundi to his spiritual Father.-First Campaign in London.-Rev. John Macdonald.-Seized with his old fever at Mr. Joseph Gurney's.-Letter to Ewart.-Expect great things.General Assembly of 1835, in the Tron Kirk.-D Duff rises from bed to make his first speech.-The Oration described.-Extracts. -The tremendous effect.-Contemporary Accounts.-Opposition and Discussion.-The Orator contrasted with the models whom he stadied.-India and India for Christ as the theme of eloquence.

H^ving successfully founded and to some extent built up the mission in Calcutta and Bengal, Mr. Duff is summoned, though he knows it not, to do the equally necessary work of creating a living missionary spirit in the Church at home. The apparently dying apostle is really being sent on that parallel or alternating service which divided his whole career into two indispensable and co-operating sets of activities in East and West. Having set the battle in array in front, and fought for years at the head of his scanty forces, he had then to leave the post of danger to colleagues of his own spirit, for the less honourable but not less necessary duty of looking to his reserves and sending forward his ammunition. Thus it was that he became at once the missionary worker, the 
unresting civilizing force in India, and the missionary organizer, the unmatched Christian orator and preacher at home. He led two lives, and in each his splendid physique, his burning enthusiasm, his divine call and support, enabled him to do more than the work of many men together.

Yet, as consciousness returned and strength began to come back, it was natural that the young missionary should long to be left at his post, should even somewhat murmuringly marvel why he had been taken away in the hour of victory. The very elements seemed to conspire to keep him in Bengal. The John M'Lellan could not breast the fury of the south-west monsoon in a Bengal July, her decks were swept again and again of the live stock laid in for the long voyage, and after six weeks' tossing she had to put into Madras for stores. By the time that she sighted South Africa Mr. Duff had become so far reconciled to the change as to be able to write thus to Dr. Bryce:- “ The very thought of returning home at the commencement of my labours and infancy of the Assembly's mission would have, I verily believe, broken my heart, were it not that God, by successive afflictions, which thrice brought me to the verge of the grave, disciplined me into the belief and conviction that a change so decided was absolutely indispensable, and that to resist the proposal to leave Calcutta would be tantamount to a resistance of the will of Providence. I shall not revert to the pain and mental distress at first experienced. God has, I trust, overruled all for my spiritual improvement; and I trust, moreover, that by my return for a season to Scotland the great cause may be effectually furthered." It was during this otherwise tedious time of slow convalescence that he seems to have read the Bible straight through three times. Beginning with the enthusiastic convic- 
tion, born of his own success, that the Church in the world would gradually glide into a milleunium of godliness, this comparative and repeated study brought him to the conclusion that the missionary work is merely preparatory to the great outpouring of the Holy Spirit. In history, as in the prophets, he ever found righteousness and peace preceded by judgments.

The invalid was just able to land at Cape Town, and with the assistance of a friendly arm walk to church, where Dr. Adamson, his host five years before, baptized the child born on the day they had left Calcutta. When the ship entered the Firth of Clydo it was Christmas-day. The sea breezes had done their best for five months, and the apparently restored missionary rejoiced in the strong frost which greeted him as from his own Grampians. When he landed at Greenock he found the whole country in the exuberant excitement of the general election under the first Reform Act, which had extended the franchise from two thousand electors who returned all the Scottish members of Parliament to something like a fairer proportion. The time of freedom in Church as well as State had begun-the conflicts which ended in the disruption of the Kirk and the abolition of the Corn Laws ten or twelve years after. The sight of election hustings was as new to Scotland as it was to Mr. Duff. Everywhere he heard only abuse of the Duke of Wellington. In Edinburgh Lord Campbell talked of impeaching "the multifarious minister" who for the hour held eight cabinet offices, till it was said, "the cabinet, council sits in his head and the ministers are all of one mind." It was seen in time that the Duke was only doing his duty till Sir Robert Peel should return from Italy and form the new ministry which first put Mr. Gladstone in office. In such circumstances sho, 
in kirk or public meeting, would listen to the tale of a triumph so remote and so obscure as that which Mr. Duff had modestly to tell. Yet the tale was really one of a spiritual revolution affecting millions, compared with which the Reform Act, the policy of Sir Robert Peel, and the training of Mr. Gladstone were but single events in a constitutional series! After a fer days spent in Greenock with the Rev. Mr. Menzies, formerly librarian of St. Andrews University, and in Glasgow with his old fellow-student, Dr. Lorimer, for both of whom he preached, Mr. Duff turned his face towards the committee in Edinburgh. He reached the capital by what was then the easiest and quickest means, the canal track-boat. Finding that Mrs. Duff's mother had been removed by death, he and his family settled down in the sea-bathing suburb of Portobello, in a house in Pitt Street lent to them by the trustees of her father's estate.

The first member of committee and personal friend on whom Mr. Duff called was Dr. Chalmers, then redeeming the fame of the University of Edinburgh in its theological faculty. Most courteous and even enthusiastic was the greeting of the greatest Scotsman of his day, who added to all his other gifts that largehearted friendliness which is the rule of his countrymen scattered abroad. The hour sped rapidly in a fire of question and answer about the progress of the mission and the state of things in India. On accompanying his visitor to the door Dr. Chalmers demanded of him, "Where is your cloak?" "I have not had time to get any," was the reply. "That will never do in this climate; it is now very frosty, and you are as thinly clad as if you were in India: let me not see your face again till you have been at the tailor's." The young missionary was already an old Indian in this, that the fire of the tropics had made him indifferent 
to his first winter in Scotland, after which comes the reaction that often drives the sufferer to the sun of the south.

But where was there another Chalmers or one worthy of him at that time in Scotland? Dr. Inglis, the founder of the mission, was gone. Dr. Brunton had not then been appointed his permanent successor. He and the other members received the ardent advances of the astonished Duff with a polite indifference, or replied with congratulations on the fact that so good a conservative statesman as Sir Robert Peel had been placed at the head of affairs, as if to save and even to extend the Kirk which had been for years furiously assailed by the Voluntaries. More than once was the young Highlander stung into the warning that for the Kirk to trust any secular statesman, however respectable, was to lean on a broken reed. The transcendent interests of a great spiritual institution like the Church of Scotland, he said, must be placed only on Christ Himself, its living Head. There was one minister, besides Chalmers, who had watched the work done in Bengal and had genius enough to appreciate it. He at once invited $\mathrm{Mr}$. Duff to begin his crusade in Falkirk. That was John Brown Patterson, the marvel of the High School of Edinburgh, whom Pillans took with him to the University; the student who had there gained the hundred pound prize proposed by. the Government commissioners on the universities of Scotland for the best essay on the character of the Athenians-an essay which, when published, was pronounced unsurpassed in English literature at the time, for its learning and style. The result of Duff's preaching in Falkirk, and of a public meeting with formal resolutions to advance the Bengal mission, was not only a collection of money which surprised all in that day, but the lighting of a flame 
which, in coming days and years, Duff was to fan and spread till it covered the land, and fired America and many other parts of Christendom. The glad report of this, made formally to the committee, was received with respectful silence. Nor was the bitterness of Mr. Duff's heart assuaged till, about the same time, two theological students called upon him for information regarding bis mission. The interview gave him a new confidence for the future, for he reasoned that if any number of the divinity students were like these, the India mission would never lack men worthy of it. His young visitors were the saintly Murray M'Cheyne and he who is still Dr. A. N. Somerville of Glasgow.

Somewhat dubious now as to the attitude of the committee, Mr. Duff received, with hesitation, the next invitation to. tell the public of his work. Dr. A. Paterson, who had been driven out of Russia by the intolerance of the Czar Nicholas, asked him to address half a dozen godly folks who met once a month in the Edinburgh house of Mr. Campbell, of Carbrook, for prayer for foreign missions. On finding the drawingroom crowded by a large audience he remonstrated, and refused to remain. But explanation showed that no endeavour had been made to summon the audience, whom he therefore consented to address. The result was, such an impression in many circles outside as well as in the Kirk, that an English risitor who had been present rode down to Portobello next morning to make a large donation to the mission, and Mr. Duff was formally summoned, for the first time, to meet the committee in the rooms in the University which Dr. Brunton occupied as librarian. Marvelling what the sudden cause could be, but delighted that at last he would have an opportunity of giving an account of his stewardship, Mr. Duff hurried to the spot with 
that punctuality for which, like all successfully busy men, he was ever remarkable.

It was thus he used to tell the story:-Entering the room be found that nearly all the members of committee were present. After prayer the acting . convener rose, and standing in the middle of the floor, in substance spoke as follows:- $-\mathrm{He}$ had thought it right to summon a meeting to settle and determine the case of Mr. Duff, who, in these days of agitation, turmoil, and revolutionary tendencies and irregularities of every description, had taken it upon him to hold not exactly a public, but at the same time a very large meeting in the house of $\mathrm{Mr}$. Campbell, of Carbrook, with the view of addressing it on the subject of missions. Now he regarded this as a very unwarrantable and irregular proceeding. Mr. Duff had given him no intimation of his intention to hold such a meeting, nor had he any means of knowing what might be the leading subject of the address. $\mathrm{He}$ thought it therefore right to consult his colleagues, to induce them to lay down rules to regulate $\mathrm{Mr}$. Duff's proceedings on such matters in future, as it would never do, in unsettled times like these, to allow the agent of a responsible committee to adopt what measures he chose.

Immediately Mr. Duff stood up, and taking possession of the middle of the floor, respectfully admitted that he was the agent of the committee, but of a committee guided by moral and spiritual influences and considerations. While in one respect therefore he was their agent, in another respect he must be considered on a footing of religious co-equality, co-responsibility with themselves; but not to insist further on this, he would soon bring the matter to a decisive issue. When he went to India originally he declared that he would not go if hampered by any conditions which his own 
conscience did not approre; that, entering upon an entirely new field, full discretion must be allowed him within the limits of reason and sobriety to follow what courses he might deem most effective for the ends which the committee and himself had alike in common. This reasonable concession was at once cheerfully yielded by Dr. Inglis and his committee; and now when he, Mr. Duff, had returned, after several years of multiplied experiences, he thought that full discretion should be allowed him to adopt what course might seem best for awakening an interest in the Church's mission, so long as he was ready to take any counsel or advice which the home experiences of members of committee friendly to missions might suggest. He then explained how the recent meeting had not originated with him; though when he came to understand it he fully approved of it, and thought that the successful result sufficiently proved its providential legitimacy. Of course, if the committee had any work for him to do of any kind anywhere, he would at once relinquish all other duty for the sake of taking up that; but beyond this he could not possibly go. He was an ordained minister of the gospel, and therefore supposed to be endowed with ordinary ministerial gifts, graces and attainments. $\mathrm{He}$ was in all respects therefore the free-man of the Lord; free to carry out whatever his blessed Master might indicate as $\mathrm{His}$ most gracious will. That liberty he would not and could not for ten thousand worlds relinquish. The decisive issue, therefore, came to be this: if the committee resolved, as they had a perfect right to do, to draw up some peremptory instructions to regulate Mr. Duff's proceedings in purely spiritual, ministerial, and missionary matters, he must at once write out his resignation as their agent. If on reconsideration they came to the con. 
clusion that it was better to allow things to remain as they were, and grant him full liberty of action within the reasonable limits stated by himself, he would rejoice in continuing as their agent, and do what he possibly could to create a deeper interest in the mission throughout the bounds of the Church, and thereby help to increase the funds and the number of agents to be sent abroad. For the people being profoundly ignorant of the whole subject, their being wakened to take a deeper interest in so spiritual a work as the evangelisation of the world would not only be carrying out more fully the last great commission of our blessed Saviour, but also tend in many remarkable ways spiritually to benefit their own souls. Having so spoken he sat down.

Instantly, all present, without any one of them uttering a single word, went out precipitately, learing $\mathrm{Mr}$. Duff and the convener alone in the middle of the floor to lcok at each other in a sort of dumb amazement. "Probably," said the former with great calmness, "we have had enough of the subject for this day."

So, on that memorable occasion, the uncompromising devotion to duty of the young missionary proved to be more powerful than all tact or ecclesiastical finesse, as it had done in more difficult circumstances among the Bengalees. Dr. Inglis was gone. The country and the Church knew nothing of the Bengal mission save from the meagre report printed once a year for a Grneral Assembly which had not then become a popular parliament. The unhappy committee wanted oniy a head to lead them. Dr. Brunton woke up to the new duties which his rare courtesy always afterw?rds sought to discharge with kind. liness. Had he referred to the scanty records of which he took charge on appointment to his 
office, he would have found an official communication, written by Mr. Duff as he sailed up the Clyde, and thus concluding:- "Why is it that the Lord was pleased so to reduce me to the verge of existence that I left the field of labour in that all but desperate condition of a dying man, and has since been pleased so wonderfully to bless the voyage to me that by the time $I$ have reached my native shores I feel enabled to encounter any reasonable share of bodily exertion? Surely it may be, or rather must be, that the Father of spirits has something or other to do with me, in promoting in this land the glorious cause-even the glorious cause of the Redeemer to which my heart and soul and life are exclusively devoted. Oh, may God grant that wise thoughts may be put into our minds, so that when we meet, measures may be devised for the occupation of my time while I remain in Scotland which He Himself will abundantly bless for the promotion of His own glory in connection with the Assembly's mission to the perishing heathen."

After Falkirk the next call came from Dr. Wilson of Irvine. Dundee followed, led thereto by a visit which Mr. Duff had paid to all its ministers on his way north to Moulin to visit bis father and mother. Meanwhile his official and private correspondence shows how necessarily active he ras in educating the new convener and committee in the progress of the mission, much of the history of which had passed away with Dr. Inglis. A letter from the Rev. W. S. Mackay on the work in Bengal called forth these "running notes" on the converts :-

"March 20th, 1835.

"If these had not been so specially referred to by Mr. Mackay I should be silent. Many in Calcutta know, and none more than my dear colleague, how much I was called on to 
do for these, and how much to bear from them during the time of their infidelity and the progress of their inquiries after truth; God only is witness of all I had to do and endure, how I had to toil and struggle and travail in soul for them. It may easily be imagined then how peculiar must my feelings towards them be. When the two first joined the English Church I was not much surprised, owing to the very satisfactory reasons stated by Mr. Mackay. And if the ground of their reasons had not been removed (as it happily now is), I should not have expected any talented young man who burned with zeal to be employed in arousing his countrymen, to remain with us-indeed I could not ask any. If the Church of England offered to ordain and support them as missionaries, and we could not, then for the good of India would I say, ' rather than remain unemployed, or betake yourselves exclusively to secular professions, by all means join the Church of England or any other Church of Christ that will engage to send you forth as effective labourers into the missionary field.'

"While therefore I did not feel surprised at the two first converts separating themselves from me, I do confess that there was an apparent want of consideration to my feelings in the mode of the separation. But while others blamed them for the act as well as the mode, and charged them with ingratitude, I really could not blame them so much as their instigators and advisers. They did not consult me, as I think they were in gratitude bound to do. The former were young and inexperienced; the latter, I fear, were actuated more by the spirit of proselyting to a party than by the love of Christ and the love of the brethren: the latter therefore, in my estimation, must bear the main burden of the blame, if blame there be. My mind is satisfied, aye my very soul kindles into joy at the thought that these my spiritual children continue steadfast in the faith, full of zeal for their Master, and conscientiously endeavour to serve Him. This noble testimony from my dear colleague is to me glad tidings indeed, for though in a measure separated in time, we may yet rejoice together, and rejoice over the fruits of our separate labours, in the realms of bliss.

"'The obvious remedy for such defections from our Church, though not from the Church of Christ, is (1) the power of ordain. 
ing and supporting qualified labourers: (2) The supporting promising young men, when cast off by their friends on account of their specially devoting themselves to the work of preparation for the Christian ministry : (3) The erection of a higher institution for the communication of the more advanced brauches of knowledge, literary, scientific and theological. The first of these is now granted; the two last are yet wanting, and till these be granted too it is utterly impossible for the Assembly's missionaries in India to be responsible for the continued adherence of well-educated pious young men to the communion of the Church of Scotland.

"Nothing would pain me more than that I should be thought to have formed too high an estimate of the character of these young men, and have led others to do so. I conscientiously believe that $I$ have understated rather than overrated that character as a whole, and that many Christians in Calcutta would give a far more flaming account than I have ever done or ever will do. I simply stated a few clear and notorions facts; I might have stated more, and drawn more glowing inferences, but purposely refrained from doing so. God knows that under the most powerful temptations to write strongly I have often written in modified terms, and often not at all. I always shrink instinctively from raising expectations that could not be realized, and if I do not greatly mistake, I think the whole tenor of my communications with the committee for the last five years bears me out in this assertion.

"In the case of the first two that were baptized, if they did not consult me, as they should have done, it was a matter altogether personal to myself, and no one perhaps could feel for them as I did, or make for them, in the peculiar circumstances of their situation, the same allowances. And seeing that the matter was personal to myself, and that I had long forgiven them before God, and that in all other respects, so far as I could observe, they continued to walk worthy of their high calling, yea, to labour without ceasing in their Master's service, I could not feel myself for a moment justified in the attempt to lower their general high character or impede their nsefulness by dwelling on circumstances to me of so personal a nature. And as the matter is so very liable to misconstruction on the part of those who must ever be more or less unacquainted with the peculiarities of the position of these young 
man, and so apt therefore to do injury to our cause, I would beg the committee never to refer to the topic of 'ingratitude' towards me. Let the causes of separation from us be freely and fully stated, if any questions be put, and stated too in order to rouse our brethren to put us speedily in possession of the remedy against future defections.

"When Gopeenath Nundi was appointed at my own recommendation to the school at Futtehpore, it was not in connection with any society. The surgeon of the station, in his application to me, expressly stated that the school was founded and would be supported by the British residents of the place. Its being taken under the patronage of the Church of England Missionary Society was altogether a subsequent event. We could not obviate this, as we had no disposable funds to offer which might secure the permanency of the institution.

"In June or July, 1833, Archdeacon Corrie was about to proceed to the upper provinces on his ministerial visitation. This was thought a favourable opportunity for Gopee, as the Archdeacon kindly offered to take him along with himself. On his return to Calcutta the Archdeacon spoke of Gopee in the very highest terms, and so also did Messrs. Hill and Paterson, missionaries of the London Missionary Society at Berhampore, and others whom Gopee had visited in his passage up the river. From himself I have never had the slightest intimation of an intention to join the English Church, though for my own part I scarcely see how he can avoid it. He is, I presume, supported to a certain extent (though I never heard any particulars) by the Church of England Missionary Society. Out of Calcutta (thanks to the supineness of our Church and her friends) he cannot enjoy the benefit of Christian ordinances but in connection with the Church of England. How in these circumstances Gopee can avoid joining the Church of England I cannot well see. Mr. Mackay states that he still retains his affection for me; I am rejoiced to hear it, for it did appear to me strong as death.

"Anundo's case is of course under consideration."

Gopeenath was afterwards ordained by the American Presbyterian Church. Anundo had been induced by Mr. Groves to accompany him to England, in the 
same ship with Mr. Duff. On his return to India he became a catechist of the London Missionary Society, and died in 1841. Whatever may have been the motives which actuated those who induced Duff's first two converts to leave their spiritual father, all must rejoice in the fine catholicity, in the rare self-abnegation which marked his own action and have ever since made his college the nursery of evangelists for all the Protestant agencies of Northern and Eastern India. $\mathrm{He}$ at least never grudged the Church of God what his own committee were unwilling or unable to utilize. And in letters such as this from Gopeenath Nundi, as well as in the continued reports of Mr. Mackay and Mr. Ewart regarding others, he found a solace and a joy of the rarest kind. Two years after his baptism Gopeenath thus concluded a long letter to Mr. Duff, from Futtehpore, beyond Allahabad, where in the Mutiny of 1857 he was to witness a good confession, having been, as he here desired, "kept faithful unto death ":-

"After I was separated from you in July, 1833, I was almost thrown alone into the world. Often I was tempted to be hopeless, and felt the need of your society. When I feel my lonesomeness, or want of a friend to open my heart to, I go to Him who is ever kind to me, and disclose my secrets. He is the only searcher of all those that are lost. He is the only friend of all the broken-hearted. He is the true leader, who leads out of the world and temptation, particularly to the new and inexperienced. Jesus is sweet unto all those that call upon Him in faith. Did He not promise that He shall be with me even unto the end of the world-then what fear? 'Let your loins be girded abont, and your lights burning!' Such are my expressions in the hour of temptation. Oh what a comfort to have Christ always, and have fellowship with Him I Is it not a great blessing to have Christ, a friend, a companion, and a conductor in all things? Then let these lines be my continual expression:- 
'If on my face, for Thy dear Name,

Shame and reproaches be;

All hail reproach, and welcome shame,

If 'Thou remember me.'

"Oh what a great mistake of them that are still wandering, not knowing where to harbour at! Did not our Lord pronounce peace on all that are His? 'Peace I leave with you, My peace I give unto you, not as the world giveth, give I unto yon : let not your heart be troubled, neither let it be afraid.' Is this peace pronounced not for all? I say it is for all, whoever he may be, whatever nation or country he belongeth to; so I am sure His peace resteth on me so long as I have sufficient faith, even unto the end of my life.

"Although we are separated by sight, still our hearts are combined in the Lord. As for my part, I find that the hearts which are once in the fellowship of Jesus cannot on any account be separated, neither by time nor by distance. We are merely separated by earthly boundaries; but our Christian love grows stronger and stronger as the day of salvation approaches. Only a few thousand miles are between you and me; but I have you always in my heart, and make mention of you in my prayers: you are scarcely gone out of my sight. But oh, remember me sometimes in your prayers. Pray not only for my sinful soul, that I may be kept faithful unto death, but also, and especially, for the souls of the poor heathens around me, that they may soon be freed from the chains of Satan and be blessed in the name of Jesus. Whether I live or die, let Christ be glorified by the ingathering of sinners to Him. I have many more trials and temptations yet to meet; but oh, may I cut short all of them through Him who is ever gracious to me. Those days are gone by when we used to converse on religions topics; more especially on Christ's condescension to save poor sinners. But we have a sure hope, that they will be renewed in a better place, and at a better time, when we come to dwell in the mansions of our heavenly Father. Oh may we soon come to that place, and greet each other with a brotherly embrace,-_inging praises to the Father, Son, and Holy Ghost, for ever and ever. Amen. Yours affectionately,

"Gopeenath Nundi."

"These lines," wrote Duff when publishing them $\mathrm{I}^{*}$ 
long after, "in their touching simplicity require no comment. It surely is not possible for any experienced. Christian to peruse them without being sensible that he is holding converse with a mind not only generically but specifically the same as his own; that he is in union and communion with a perfectly congenial spirit-a spirit new-moulded and fashioned after the similitude of Christ-a spirit whose heavenward breathings would, with talismanic effect, mark out its possessor from amidst the countless throng of his turbaned countrymen as belonging to the spiritual confederacy and brotherhood of the faithful."

In April, 1835, after making the amende honorable, the convener submitted to Mr. Duff a letter from the clerk of the Presbytery of London, expressing profound interest in the India mission of the established Church of Scotland, and inviting the missionary to preach to and address each of the congregations, which were ready to begin a system of contributions for the good cause. There was only one dissentient in the Presbytery, as it proved, and that solely from ignorance. He was the Rev. John Macdonald, who, when he heard the good news of God from Bengal and understood how an educational agency like Duff's was the most evangelistic of all as directed to cultured Hindoos, gave himself to the same service, resigning his London charge for the Calcutta mission. Having accomplished his congenial task, Mr. Duff happened to be breakfasting with Mr. Joseph Gurney, the Christian philanthropist who superintended the system of shorthand reporting in the House of Lords. The missionary was about to set out for the final meeting of representatives of all the congregations, when, as he lifted a cup of coffee to his lips, he was seized with the violent shivering which marked the return of his old fever. He was nursed in Alderman Pirie's house 
for three weeks, and insisted on returning to Edinburgh for the General Assembly, which he reached by steamer apparently a wasted skeleton.

\section{"London, Camberweld, 20th May, 1835.}

"Mr Dear Ewart,-I need not say how rejoiced I was when I heard of the step you had taken. May the God of grace strengthen and uphold you : may He pour upon you of the richest effusions of His grace: and may He render your labour effectual in advancing the Redeemer's kingdom in the benighted land of your adoption. By this time you will have become acquainted with the state of things in Calcutta. It is needless therefore for me to refer to it. The pushing on of the advantages already gained in our Institution is a matter of paramount importance. The raising up of a class of native teachers and preachers from our Institution is the only thing that will meet the demands of India, the only thing that will reconcile the people at home to our proceedings. Therefore every nerve should be strained towards the accomplishment of this end. The day that the presbyterial board of Calcutta shall ordain one of our young men for the work of the ministry will be a glorious day for India and for our cause. Such an event would do more than anything else in the way of arousing our countrymen at home. When ordained, of course the young missionary should be employed in or near Calcutta, within reach of superintendence and direction.

"I came to London about a month ago, and have preached or delivered addresses in all our Scotch churches here. All of them have now formed, or are about to form, congregational associations in support of our cause. I was to have spoken at some of the great anniversary meetings held here in May; but on 
Saturday, the 2nd of May, I was seized with a severe attack of my old friend, or enemy, the Bengal intermittent fever, which has up to this date confined me to the house. I am now through God's blessing nearly recovered; but the consequence has been that for the present the finest opportunities for making our cause extensively known in this great metropolis have been lost. It does look mysterious, but no doubt we shall yet find that God has ordered it for the best.

"While I have been advocating the claims of our mission generally, and the necessity of increasing prayerfulness and increasing contributions, I have not forgotten the special calls for more suitable accommodation for our Institution, for an extensive library, apparatus, etc. Things are progressing towards something effectual being done in these respects. I have now just attended a general meeting of the Religious Tract and Book Society, and pled in behalf of our Institution. The committee have accordingly unanimously roted a grant of all their publications, amounting in value to about $£ 30$. My affectionate regards to Mr. and Mrs. Mackay, Dr. Bryce, Mr. and Mrs. Charles, the members of session, brother missionaries, etc. Yours affectionately,

"Alexander Djff."

Duff had now a work to do, and to do at once, compared with which his crusade in Bengal had been pleasant. The opposition there was what he had counted on; it had inspirited him with eagerness for the battle, and he had been successful. In his own land he had had just experience enough to sound the depth of ignorance, and consequent indifference to India and the state of its people. The few who were of the spirit of Dr. Inglis, removed by death; Simeon, 
near his end; Dr. Love, removed to Glasgow after founding the London Missionary Society; John Foster, Charles Grant and Wilberforce, gathered round the societies, leaving Churches, as such, colder than before. Irvine and Falkirk were exceptions in the presbyteries of his own Kirk; even the London Scotsmen were represented as more desirous to wipe off the reproach of Unitarianism by inviting him to their midst than to advance foreign missions. We have seen what his own committee, on the removal of Dr. Inglis, knew of his doings, and how little they understood the magnitude of his aims. Just ten years had passed since the General Assembly had been induced with difficulty to invite a general collection for the proposed Indian Mission, by the assurance, prominently published, that it was " not to be repeated," yet not fifty out of its thousand churches made any response. Dr. Inglis was so delighted by the consent of the Presbytery of Edinburgh to make an annual collection, even in 1831, that he announced it to Duff as a triumph, and declared he would now fix the maximum revenue for the mission at $£ 1,200$ a year. From the front of the battle, in all its heat and vastness, the missionary had replied, "Not $£ 1,200$ but $£ 12,000$, and do not stop at that." How had that reply been received ? When, before the Assembly of 1835, Duff was reading up the meagre records of the committee, he found that a leading member had written on the margin of that reply, "Is the man mad? Has the Indian sun turned his head?" When he pointed out the query, its writer, now himself convener, tore it off and threw it into the fire, exclaiming, "No more will be heard on that subject." But, in high and low, this was the want of knowledge and of faith which the first Scottish missionary who had returned from India was called to meet. And the return of the old fever of the rice swamps of 
Bengal, following his London campaign, had mads him once more a gaunt invalid.

Physicians and friends tried to dissuade him, and the list of business that year, which followed the ecclesiastical reforms of 1834 , was so large that it was doubtful if time would be found for even the Inclia Mission. What was all the administration of Lord William Bentinck, or all the codes and the essays of Macaulay, to a general election? what the evangelization of Bengal to the presbyters of Auchterarder? But Duff knew that this was his time; that if he died he must yet deliver his soul and tell his tale. He could have no prosperous mission in India without Scotland, and every Scottish man, woman and child could be reached best through the reports of the General Assembly, which the reforms of 1834 had made the most popular of parliaments.

Casting himself on the promise to Paul, the first and greatest of missionaries, that the grace of God would be sufficient for him, yea, would be perfected even by his weakness, Mr. Duff resigned himself passively into the Divine hands. In those days he did not commit a speech or address to writing, but thoroughly conned over the materials of it, leaving the expression to the time when he should stand eye to eye with the crowd. The reforming party in the Kirk had established the Scottish Guardian as their weekly newspaper, in Glasgow, and the editor, the Rev. George Lewis, had formed a volunteer staff of reporters of the Assembly's proceedings. Brother of one who was a warm friend of Mr. Duff-Dr. James Lewis-and himself one of the fer interested in the subject, he instructed his staff to take down as full a report of the missionary's speech as possible. Monday, the 25th May, 1835, had been assigned for what had bitherto been the purely formal duty of presenting 
the annual report of the India Mission. The Assembly met in that most unecclesiastical large box called the Tron kirk of Edinburgh. Though in the monhanical sense unprepared, and just risen from a sick bed, Mr. Duff testified often after, that never during his whole life did he more thoroughly experience the might of the Divine saying, "As thy day so shall thy strength be." At first it seemed as if he could not go on beyond a few sentences, and he was conscious that many were gazing at him, apprehensive, as they afterwards said, that he would soon drop on the floor. But, leaping by one effort into the very heart of his subject, he became unconscious of the presence of his audience save as of a mass which was gradually warming to his heat. Advancing from stage to stage of what was, for him, "a brief exposition," he whispered out his at that time unmatched peroration with an almost supernatural effect, and subsided drenched with perspiration as if he had been dragged through the Atlantic, to use his own expression. Then for the first time he marked the emotion of his hearers, many of them callous lawyers and lords of session, cool men of the world or antipathetic " moderates." Down the cheeks of even these the tears were trickling.

With the unconsciousness of the highest art their first Indian missionary at once planted the General Assembly beside him in Bengal, as he set himself to " the conversion of a hundred and thirty millions of idolaters." Step by step he hurried them on from the first attempt, on the old system, to influence the educated Hindoos, through the statement of the evidences of Christianity, of miracles, prophecy and the demand for the proof of the missionary's authority, till this conclusion was reached: "The power of conveying the necessary knowledge seems to me to be the only 
substitute we possess instead of the power of working miracles. But it is surely one thing to say, that a sound liberal education is greatly advantageous towards the establishment of the evidence and authority of the Christian revelation, and, consequently, towards securing a candid and attentive hearing, and quite another to say, that it is indispensably and universally necessary to the heart reception of the gospel remedy. The former position we do most firmly maintain, but in the solemnity of apostolic language, we exclaim, God forbid that we should ever maintain the latter! Instead of demanding your authority for the truth of Christianity, the Brahman may challenge you to invalidate, if you can, the claims of his system. You soon find that there is no common ground in logic, and you turn to the experimental principles of physical science to find the cataclysms of the Hindoo cosmogony exalted against the petty, the recent learning of the West. You turn to theology proper, only to find that the Vedic Shasters sanctify and render infallible all Brahmanism, secular as well as sacred. Do then," exclaimed Duff, after pleading for the supply of missionaries "qualified to silence the intellectually proud as well as to edify the spiritually humble,"

"Do then let me again crave the attention of this venerable court to the grand poculiarity, that if in India you only impart ordinary useful knowledge, you thereby demolish what by its people is regarded as sacred. A course of instruction that profosses to convey truth of any lind thus becomes a species of religious education in such a land-all education being there regarded as religious or theological. Every branch of sound general knowledge which you inculcate becomes the destroyer of some corresponding part in the Hindoo system. It is this that gives to the dissemination of mere human knowledge, in the present state of India, such awful importance $:$ it is this that exalts and magnifies it into the rank of a primary instrument in spreading the seeds of reformation throughout the land. I ask 
not, whether sound usefuł knowledge be universally necessary, either as the precursor or friendly ally of that which is divine. Such is neither my own impression nor belief. But, seeing that the communication of useful knowledge becomes, in the circumstances described, such a tremendous engine for breaking down the accumulated superstitions and idolatries of ages, I do ask, in opposition to those who decry and denounce useful knowledge, not in the abstract but as totally inapplicable to missionary purposes,-I do ask, with humble but confident boldness, as in the sight of Heaven, 'Who is it that will henceforward have the hardihood to assert that the impartation of such knowledge has nothing to do with the christianization of India?" "

But the European, the foreign missionary to the educated Hindoos soon comes to discover further, that if the gospel is to be extensively preached with power it must be by natives themselves, whom it is his task to duly qualify. Appealing to the Highland ministers among his audience, the speaker used the same old analogy of the Gaelic and English which he employed with such effect against the one-sided orientalists of Calcutta :-

"Oh, there is that in the tones of a foreigner's voice which falls cold and heary on the ear of a native, and seldom reaches the heart!-whereas, there is something in the genuine tones of a countryman's voice, which, operating as a charm, falls pleasantly on the ear, and comes home to the feelings, and touches the heart, and causes its tenderest cords to vibrate. Doubtless there have been, and there may be now, individual cases of foreigners having in some degree, or even altogether, surmounted this grand practical difficulty. But these rare cases form such palpable exceptions from the general rule, that they can scarcely be counted on, in providing a national supply of preachers of the everlasting gospel. Thus, again, is the comparative inefficiency of European agency, when put forth directly in proclaiming the gospel, forced upon the mind; and the necessity of having recourse to native agents in the work is once more suggested with a potency that is resistless. They 
can withstand that blazing sun, they can bear exposure to that unkindly atmosphere, they can locate themselves amid the hamlets and the villages, they can hold intercourse with their countrymen in ways and modes that we never can. And having the thousand advantages, besides, of knowing the feelings, the sentiments, the traditions, the associations, the habits, the manners, the customs, the trains of thought and principles of reasoning among the people, they can strike in with arguments, and objections, and illustrations, and imagery which we could never, never have conceived. How glorious then must be the day for India when such qualified native agents are prepared to go forth among the people, and shake and agitate, and rouse them from the lethargy and the slumber of ages !

"It is for reasons like the preceding, that a man of fervent piety, going forth with the fullest intention of doing nothing but directly and exclusively preaching the gospel in the native tongues, of ten finds himself, in such a country as India, constrained to think of other and more effectual means of ultimately accomplishing the same work, and hastening the same consummation."

Then followed a graphic description of the speaker's own mode of overcoming such difficulties; a pathetic picture of the separation of his third convert from father and mother, from brothers and friends, for ever; and a contrast, which time has unhappily only proved at once a prediction and a justification, in the political results of the system which the Government of India alone of all ruling powers, civilized or barbarous, pursues-public instruction carefully divorced from all religion:-

"If in that land you do give the people knowledge without religion, rest assured that it is the greatest blunder, politically speaking, that ever was committed. Having free unrestricted access to the whole range of our English literature and science they will despise and reject their own absurd systems of learning. Once driven out of their own systems, they will inevitably become infidels in religion. And shaken out of the 
mechanical routine of their own religious observances, without moral principle to balance their thoughts or guide their movements, they will as certainly become discontented, restless agitators,-ambitious of power and official distinction, and possessed of the most disloyal sentiments towards that Government which, in their eye, has usurped all the authority that rightfully belonged to themselves. This is not theory, it is a statement of fact. I myself can testify in this place, as I have already done on the spot, that expressions and opinions of a most rebellious nature have been known to drop from some of the very protegés of that Government which, for its own sake, is so infatuated as to insist on giving knowledge apart from religion. But as soon as some of these became converts to Christianity, through the agency already described, how totally different their tone of feeling towards the existing Government? Their bowels yearnod over the miseries of their countrymen. They now knew the only effectual cure. And their spontaneous feeling was, 'Ah! woe be unto us, if the British Government were destroyed and the Hindoo dynasties restored! The first thing would be to cut us off, and what would then become of our poor degraded country? We pray for the permanence of the British Government, that, under the shadow of its protection, we may disseminate the healing knowledge of Christianity among our brethren, - that knowledge which alone can secure their present welfare and immortal happiness.' In like manner, and for the same reason, there are not more loyal or patriotic subjects of the British crown than the young men that compose the more advanced classes in our Institution. So clearly and strongly did this appear to many members of the present Government in India, that instead of regarding us with jealousy and suspicion as enemies, they looked upon us as the truest friends of the British Government, the staunchest supporters of the British power."

The adoption of English as the language of the higher education, the abolition of foreign Persian as the official medium, the use of the vernaculars for giving knowledge to the millions, the spread of the higher education from Calcutta to the great cities and feudatory states of Upper and Central India, and the 
duty of Scotland through its Kirk, all the more since the death of Inglis, carried the orator to his climax, which became a model of rhetoric for many a year after in the schools and manuals of elocution:-

"Whenever we make an appeal in behalf of the heathen, it is constantly urged that there are enough of leathen at home, - that there is enough of work to be done at home, and why roam for more in distant lands? I strongly suspect that those who are most clamorous in advancing this plea are just the very men who do little, and care less, either for heathen at home or heathen at a distance. At all events, it is a plea fir more worthy of a heathen than of a Christian. It was not thus that the apostles argued. If it were, they never would have crossed the walls of Jerusalem. There they would have remained contending with unbelieving Jews, till caught by the flames that reduced to ashes the city of their fathers. And if we act on such a plea, we may be charged with despising the example of the apostles, and found loitering at home till overtaken by the flames of the final conflagration. But shall it be brooked that those who in this Assembly have so far succeeded to their office, should act so contrary a part? Let us pronounce this impossible. I for one can see no contrariety between home and foreign labour. I am glad that so much is doing for home: but ten times more may yet be done both for home and for abroad too. It is cheering to think of the overmastering energy that is now put forth in the cause of church extension in this land, as well as in reference to improved systerns of education, and model-schools, and more especially the enlightenment of the long-neglected and destitute Highlands. I know the Highlands; they are dear to me. They form the cradle and the grave of $m y$ fathers; they are the nursery of $\mathrm{my}$ youthful imaginings; and there is not a lake, or barren heath, or naked granite peak that is not dear to me. How much more dear the precious souls of those who tenant these romantic regions! Still, though a son of the Highlands, I must, in my higher capacity as a disciple of Jesus, be permitted to put the question, Has not Inspiration declared, that 'the field is the world'? And would you keep your spiritual sympathies pent up within 
the craggy ramparts of the Grampians? Would you have them enchained within the wild and rocky shores of this distant isle? 'The field is the world.' And the more we are like God,-the more we reflect His image,-the more our nature is assimilated to the Divine,-the more nearly will we view the world as God has done. 'True friendship,' it has been said, 'has no localities.' And so it is with the love of God in Christ. The sacrifice on Calvary was designed to embrace the globe in its amplitude. Let us view the subject as God views it-let us view it as denizens of the universeand we shall not be bounded in our efforts of philanthropy, short of the north or south pole. Wherever there is a human being there must our sympathies extend.

"And since you, here assembled, are the representatives of that National Church that has put forth an einphatic expression of faith in the Releemer's promises; an emphatic expression of expectation that all these promises shall one day be gloriously realized-and in these troublous times this is a precious testimony-I call upon you to follow it up with deeds proportionate. 'Faith without works is dead.' Let you, the representative body of this Church, commence, and show that the pulse of benevolence has begun to beat higher here, and if so, it will circulate through all the veins of the great system. Let the impulsive influence begin here, and it will flow throughout the land. Let us awake, arise, and rescue unhappy India from its present and impending horrors. Ah! long, too long has India been made a theme for the visions of poetry and the dreams of romance. Too long has it been enshrined in the sparkling bubbles of a vapoury sentimentalism. One's heart is indeed sickened with the eternal song of its balmy skies and voluptuous gales-its golden dews and pageantry of blossoms-its

\footnotetext{
'fields of paradise and bowers, Entwiuing amaranthine flowers,'-
}

its blaze of suns, and torrents of eternal light:-one's heart is sickened with this eternal song, when above, we behold nought but the spiritual gloom of a gathering tempest, relieved only by the lightning glance of the Almighty's indignation-around, a waste moral wilderness, where ' all life dies, and death lives'-and underneath, one vast catacomb of 
immortal souls perishing for lack of knowledge. Let us arise, and resolve that henceforward these 'climes of the sun' shall not be viewed merely as a storehouse of flower's for poetry, and figures for rhetoric, and bold strokes for oratory; but shall become the climes of a better sun-even 'the Sun of right. eousness;' the nursery of 'plants of renown' that shall bloom and blossom in the regions of immortality. Let us arise and revive the genius of the olden time: let us revive the spirit of our forefathers. Like them, let us unsheathe the sword of the Spirit, unfurl the banners of the Cross, sound the gospel-trump of jubilee. Like them, let us enter into a Solemn League and Covenant before our God, in behalf of that benighted land, that we will not rest, till the voice of praise and thanksgiving arise, in daily orisons, from its coral strands, roll over its fertile plains, resound from its smiling valleys, and re-echo from its everlasting hills. Thus shall it be proved, that the Church of Scotland, though 'poor, can make many rich,' being herself replenished from the 'fulness of the Godhead:'-that the Church of Scotland, though powerless, as regards carnal designs and worldly policies, has yet the divine power of bringing many sons to glory; of calling a spiritual progeny from afar, numerous as the drops of dew in the morning, and resplendent with the shining of the Sun of righteousness-a noble company of ransomed multitudes, that shall hail you in the realms of day, and crown you with the spoils of victory, and sit on thrones, and live and reign with you, amid the splendours of an unclouded nniverse. "May God hasten the day, and put it into the heart of every one present to engage in the glorious work of realizing it !"

The long-drawn sigh of the profoundly moved hearers relieved the suppressed emotion which lighted up or bedimmed every face. The presence of God alone was the fitting place at such a time, and Dr. Gordon was unanimously called on to lead the devotions of the Assembly in praise and thanksgiving to God. When the tumult of emotion was thus chastened, one after another of the leaders of the house, on both sides, rose to give expression to his feelings. Among these was the venerable Dr. Stewart, 
of Erskine, who thus spoke:-"Moderator, it has been my privilege to hear Mr. Fox and Mr. Pitt speak in the House of Commons, that grand focus of British eloquence, when in the very zenith of their glory as statesmen and orators. I now solemnly declare that I never heard from either of them a speech similar, or second to that to which we have now listened, alike for its lofty tone, thought and sentiment, its close argumentative force, its transcendent eloquence and overpowering impressiveness." The Rev. J. W. Taylor, of Flisk, still lives to give us this reminiscence of that day:-

"Before Alexander Duff left St. Andrews for India there was a meeting of the Students' Missionary Society in St. Mary's College. I stumbled up the dark stairs, and when I got into the room, I found Duff addressing a small meeting, and lamenting in his own pathetic way the little interest which the cause of Christ and of missions was awakening in the student mind. The next time I heard Duff was in the General Assembly of 1835. I was there as a volunteer reporter to the Scottish Guardian. It was fortunate that the reporting of Duff's speech was entrusted to the cool head and steady hand of Professor Chalmers of London. All the rest of us reporters sat spell-bound. There stood Duff in front of the square box-like enclosure which contained the moderator, the procurator, the clerks, and the more distinguished leaders of the Assembly. The look of modesty, of dignity, of anxiety, as if conscious that the future of his plan of Indian missions was suspended under God upon the impression which would be made that day upon that Assembly, won the interest of every one in the crowded house. And as the great missionary went on expounding in his own deep heart-moving tones his great method of overthrowing Hindooism by the combined agencies of a sacred education and of the Bible, for betwixt two and three hours he held the vast audience under the sway of his commanding eloquence, and when he finished one conviction possessed every heart-this is the key-note for India's evangelization. Many old ministers who had been cold in the cause of missions, and many moderate ministers 
who had been opposed to missions, dated the rise of missionary zeal in their hearts from the speech of that day. Even Dr. George Cook, who in his lectures to his students was accustomed to argue against foreign missions, under the stirring impulse of Dr. Duff's address rose and vied with the evangelical brethren in expressing his admiration of the zeal, the skilfulness, the devotedness and big-heartedness of the great missionary.

"The first India mission speech of Duff was sufficient of itself to signalise any Assembly. But the Assembly of 1835 was rendered further illustrious by the famous speech of Rev. Andrew Gray, demanding for chapels of ease the status of Fresbyterian Churches, and the constitutional provision of kurk-sessions and representation in the Presbytery."

The Scottish Guardian of next day wrote thus :"Mr. Duff's speech will be found at full length in our columns, occupying the most prominent place in the proceedings of the Assembly of yesterday. It has thrown a flood of light upon the christianization of India, and furnished principles and information for guiding our Church which will lead to an entire new model of missions, and give, we trust, a new direction to all the efforts of the Christians of Britain in behalf of India. It would be vain for us to attempt to describe the impression which the lofty, intelligent Christian enthusiasm and fervid eloquence of $\mathrm{Mr}$. Duff produced upon the Assembly. Every heart felt his appeal, and every understanding approved the wisdom and sagacity of the means which he proposed for giving success to the missionary enterprise and achieving the christianization of India. It will be long ere the Assembly will forget his pleading. His appearance has thrown a sacredness around its meeting, and will give a Christian elevation and dignity to the whole of its procedure. His speech will yet tell in its moral influence, not only in the cottages of India, but in the cottages of our own land, and will send 
back our clergy to their homes smitten with the missionary and apostolic spirit that burns with sweet fervour in the breast of our devoted missionary. Who would not pray God that he might have the same wisdom and Christian zeal, and might bring these to bear upon the christianization of his own allotted vineyard in the Church, with the same success as Mr. Duff promises to concentrate them upon his Indian enterprise?"

The Presbyterian Review of the following July described the whole house as " absorbed in one feeling, exquisite even to pain; tears ran down almost every cheek" during the address. The historian of "the ten years' conflict," declaring that it is difficult to refer, at this distance of time, to the impression which it produced without using what may seem like the language of exaggeration, records :- "It was indeed a token that better days had come for the Church of Scotland, when Chalmers and Duff were contemporaneously making the whole country resound with their noble pleadings-the one for the heathen at home, the other for the heathen abroad." The General Assembly ordered the publication of the address, and two editions of trenty thousand copies, following the newspaper, spread it abroad, not only over Great Britain, but in America and many parts of. the continent of Europe. In Scotland, as in India, the first battle of the campaign had been won.

But only the first. For it was natural and advantageous that this, the earliest adequate statement in the West of what has since been called the educational system of missions, should excite discussion and bring down on its advocate the charges, now of overlooking other agencies and then of being an innovator, now of departing from apostolic precedents and again of not sufficiently recognising the difference between the 
state of the British and of that of the Roman empire. Dr. Wilson also had protested against, and had departed from the stereotyped and fruitless policy of the missionaries whom he had found in Western India, but that was in India itself, and the Scottish Missionary Society had reproved him instead of publishing his communications. Both the Bengal and the Bombay apostles taught and practised the system which Scripture, their Church and experience alike led them to elaborate independently of each other-that of christianizing the Hindoos, Parsees and Muhammadans, who are each the inheritor of a complex body of religion, philosophy and literature, by public and private discussion, and by continuous instruction in Western truth through the English language. In their hands, and that of all their worthy successors in every Church and society, colleges, lectures, frank discussion, daily tuition become, for these classes, as truly evangelistic and converting as village preaching and purely vernacular teaching for the simple nonAryan peoples.

Never did public speaker in any assembly think less of himself or of the form of his oratory, and more of the message which he believed he was charged by his Master to deliver to the Church and the country, than did Duff. Hence the immediate influence on those who heard him, and the abiding power of the printed report of what he said, although that fell far below the reality in days when verbatim reporting was unknown. He spake as a prophet, not as a carefully prepared rhetorician. This redeemed his orations from the dangers of the florid style which was the fashion of that period of literature, while it gave him the power of the more recent school of eloquence, of which Mr. Bright is the master. More nearly than any of the speakers of the first 
half of the nineteenth century, Duff thus realized that which Mr. Gladstone has pronounced the supreme influence of the speaker, the power of "receiving from his audience in a vapour what he pours back on them in a flood." But, while eschewing the mechanical or formally rhetorical preparation which would have cramped while it polished his utterance, Duff - did not neglect the careful and admiring study of the masters of English eloquence, from Chatham and Burke to Erskine and Canning. A little collection of their master-pieces published in 1827 seems to have been, at one time, his constant compa:ion. It is carefully marked at such speeches as these-Mr. Pitt, in vindication of his father, Lord Chatham; Mr. Fox, in respect to the Government of Iudia; Mr. Grattan, on moving for a committee on the claims of the Roman Catholics; and Mr. Brougham on the slave trade. From these was the form of his oratory unconsciously derived; but not more from these than from Chalmers - his St. Andrews lectures on moral philosophy, emancipation speech and sermons, such as Mr. Gladstone to this day pronounces equalled only by the very different "reasoned homilies" of John Henry Newman.

Duff, too, was at once as fortunate and unfortunate in his principal theme as his greatest models. For if the India of popular fancy casts a glamour over the imagination, the novelty of its names, customs, and beliefs repels the mind which desires the passive enjoyment of eloquence in proportion to the earnestness, the fulness and the accuracy of the speaker. On India showy platitudes tell where authoritative knowledge, even when expressed in the chastest rhetoric, fails to attract. Witness the contrast, at the present day, between the popularity of Macaulay and-in this sense-his successor, Sir Henry Maine. Duff's first Assembly address was precisely what Sheridan's 
celebrated Begum of Oudh speech had been-unex. pectedly magical in its effect on the hearers, but lost to a great extent in the report. It was India that revealed Burke as the orator he became. The knowledge which he gained in the select committee of 1780 fed his imagination with events even more distant and new than the Terror of the French Revolution. Into that imagination the malicious Francis dropped the spark which caused it to explode into the five great speeches on the impeachment of Warren Hastings. After Sheridan had failed in that year, so that, like a living statesman of the same type, be exclaimed to Woodfall, "It is in me, and it shall come out," India enabled him to make the speech which led the House to adjourn, from the impossibility of debating judicially after it. Burke, Fox and Pitt united in declaring it the most extraordinary effort of human eloquence, ancient or modern, just as the venerable Stewart of Erskine said of Duff's that it surpassed the finest efforts of Fox and Pitt, yet these speakers were second only to Burke in the higher flights of the imagination, in the abandon which resulted from absorption in their subject. The impartial and experienced Wilberforce did not mean to praise Canning when he said that that speaker never drew you to him in spite of yourself, as Pitt and Fox used to do, yet he was a more finished orator than either. Canning had wit and humour inconsistent with abandon, but as precious in themselves as they are rare. Duff manifested powers of sarcasm and scathing indignation when he rose to the heights of his prophetic message and was called to demolish opposition or expose hypocrisy in the name of his Master. For it was not India only, but India for Christ, that was the source of his inspiration. 


\section{CHAPTER XI.}

1835-1836.

\section{DR. DUFF ORGANIZING.}

Degree of Doctor of Divinity.-Dr. Duff called to fill the place of Dr. Inglis in Old Greyfriars.-Offered Sonth Church, Aberdeen, and recommends Dr. Tweedie.-The Higher Calling of the Missionary.-The Marnoch Case.-Pressed by the Earl of Fife to prevent Schism by accepting the Living.-Plan of Rousing every Presbytery formed on the Voyage Home.-Foreign Missions ontside of Chnrch Parties. - The First Campaign of 1835.-Experiences in the Far North.-Euthnsiastic Reception.-Retnrn of Fever.-The Second Campaign, of 1836, opened in Perth.Description by Eye-witnesses. - Dr. William Thomson. - Dr. Guthrie and the Opponent of the Law of Gravitation.-Invitations from England.-Speech for the Church Missionary Society. -The Gnest of Carus in Trinity College, Cambridge.-Sacred Interview with the aged Simeon.- Memories of the Monlin Revival.-Whewell.-Original MS. of the "Paradise Lost," as a Drama.-Milton and the Cam.-Dr. Dnff addresses Public Meeting called by the Mayor.-At Leamington with Dr. Jephson.News from Calcntta.-Intercourse with Lord William Bentinck.

FaR more effectually than even the speaker had dared to dream, the first Assembly oration of the first missionary of its Church set Scotland on fire. The excitement of the general election, which for the hour made Dr. Chalmers so much of a Tory as to call forth the remark in his broadest Fifeshire accent, "I have a moral loathing of these Whugs," had spent itself. The new spiritual life which was to work itself out in the disruption of 1843 had asserted its power in the General Assemblies of 1834 and 1835. Even Dr. Inglis had declared just before his death, "The 
kingdom of Christ is not only spiritual but independent. No earthly government has a right to overrule or control it." Chalmers, with such disciples as the young Thomas Guthrie, had begun to go forth on his evangelical mission of church extension throughout the length and breadth of Scotland. Side by side and in loving co-operation with that, as Chalmers had always taught and he himself had again enforced, Duff proclaimed and established the claims of foreign missions. The whole people were ready to receive the missionary; almost every parish competed for a visit from him. Zealously anticipating St. Andrews and the other universities, Marischal College, Aberdeen, had hardly met for the autumn session of 1835 when it honoured itself and surprised the young divine, still under thirty, by presenting him with the diploma of Doctor of Divinity.

The most embarrassing and even annoying form taken by the popularity thus suddenly acquired and steadily increased for many a year, was that of the patrons of church livings, and the then few congregations who had the right to call their own minister, persecuting Dr. Duff to settle amongst them. $\mathrm{He}$ must effectually clear this obstacle out of his path before entering on his first home crusade. What to some would have seemed a flattering recognition of their merits was to him at once humiliating and irritating. That it should be supposed he would even consider proposals to retreat from the front of the battle into the easy and yet respectable comfort of the baggage, was an evidence of the dense ignorance which long prevailed regarding the missionary duty of the Church, and a reflection on his own sacrifice to that duty. Dr. Inglis was gone. Dr. Anderson, who had been appointed his successor, soon followed him, and the otherwise attractive city charge of Old 
Greyfriars was pressed upon Dr. Duff. The patrons were the Lord Provost, then the Honble. Mr. Trotter, and the town council of Edinburgh, but they had promised to leave the election in the hands of the congre: gation if it were unanimous. On the very morning when Dr. Duff was to open his crusade in the country, just half an hour before he was to leave his house for the Perth stage-coach, which then started from the Black Bull Inn, at the head of Leith Walk, he was stopped by a deputation from the kirk-session and people offering him the living. When he showed some impatience under the long catalogue of weighty reasons which they advanced for his closing with their urgent request, they thought that they would secure him by the temptation of preaching for the rest of his days amid the grandest ecclesiastical and historical associations, and in the pulpit of his old friend Dr. Inglis. Hardly had he escaped from a position which Professor Wilson's cousin, John Syn, was to fill side by side with Dr. Guthrie, and reached the Highlands, when the South Church of Aberdeen laid hold of him. Determined not to lose the advantage of his services altogether, the disappointed people besought him to name a candidate most like to himself. The delicacy of this duty troubled him; but he met the repeated invitation to assist the congregation by directing their attention to Dr. Tweedie, his old fellow-student; whose ability he had again personally recognised in London Wall Presbyterian church. The Aberdeen people had plied him with the argument that, by meeting their request, he would be able to adrocate the claims of India at home. In the appendix to the published sermon on the mutual duties and responsibilities of pastor and people, which he preached on. introducing the new minister to the church, he thus dealt with that consideration :- 
"Were I to remain in my native land, it would donbtless be still in my power to do something by way of advocating the claims of poor benighted India. In that case, however, methinks my tongue would not only falter, but often 'cleave to the roof of my mouth.' Fearlessly and nnsparingly have I reprobated the indolence and cowardice of those who kept lingering, lonnging and loitering at home, in lazy expectation of some snug peaceful settlement, instead of nobly marching forward into the wide field of the world, to earn new trophies for their Redeemer, by planting His standard in hitherto unconquered realms. Neither have I suppressed my honest indignation at the no less criminal supineness of others, who, having once obtained such settlements, ingeniously devise a thousand petty frivolous pretexts for continuing to wrap themselves $\mathrm{up}$ in the congenialities and luxurious indulgences of home, instead of boldly daring, though at an immeasurable distance, to tread in the footsteps of apostles and prophets and martyrs. Not that I would have such loiterers to join our storming ranks. Far otherwise. I, for one, would wash my hands of the guilt of appending such drags to the chariot wheels of the conquering Messiah. The grand evil is that such persons should exist at all, arrayed externally in the garb of the heralds of salvation. How often have our ears been regaled with the music of eloquence, echoing the songs of divine chivalry and the battles of the faith? But all the while have we not been left in sorrow to exclaim,-Where the rushing crowd of champions, clad in armour of light? Where the continued toiling, and struggling, and fighting which form the certain prelude to decisive victory? Alas! alas! if withont an effort, without a struggle and without a sacrifice, imagination alone could conquer all difficulties, then, with the ease of some potent spell, and the rapidity of some inexplicable enchantment, might we behold every howling waste converted into gardens of delight, and golden palaces starting from erery barren shore! Such sentiments and expressions niay be deemed by many over-severe and not a little uncharitable. If so, I cannot belp it. What I feel strongly I express strongly. How then could $I$ in consistency, after such decisive expression of my own feelings, reconcile myself to the resolution of throwing aside my weapons of aggressive warfare, and timidly shrinking down into the shrivelled form of a comfort-seeking 
time-server at home? What a plausible corroboration might thereby be given to the base calumny, that few or none go forth to heathen climes but such as have been unsuccessful and disappointed candidates for office in their native land,the only merit allowed them being the ignoble one of making a virtue of necessity? What a triumph might be furnished. to the thousands who stoutly call in question the sincerity of those who profess their willingness to submit to sacrifices for the sake of Christ? And with what shouts of derision might any appeals of mine, on the subject of personally engaging in the toils of missionary labour, be responded to ?"

The third among many other temptations put before Dr. Duff was of a different and, in an ecclesiastical sense, still higher kind. It was nothing less than this, that he might save the Church of Scotland from being rent in two by the conflict for spiritual independence which had now entered on its life and death stage. The famous Marnoch case, with all the Strathbogie scandals, was in its early stage, having succeeded the first assault of the civil courts, made in the Auchterarder case, on the spiritual independence in purely spiritual things guaranteed to the Kirk by Scottish Acts of Parliament, the 'Ireaty of Uuion and the Revolution Settlement. Marnoch is a small parish on the Deveron, nine miles south-west of Banff. The Earl of Fife was patron of the living, which fell vacant after the Act of the General Assembly restoring to communicants their spiritual and historical right to veto the patron's appointment of a minister of whom they disapproved. The earl, who had settled down in Duff House, was indifferent to the Veto Act, but he did not wish the annoyance of fighting his own tenantry on such a question. In the days of his dissipation as boon companion of George IV., he had allowed his brother, General Duff, to promise the living, when it should be vacant, to one Edwards, long a tutor in the family. 
But the old minister would not die, while the Veto Act represented an earnest change of popular opinion on the traffic in livings which had once already rent the Kirk, having degraded the nation ever since Queen Anne's days. The earl, having sobered down, at first tried to induce his brother to release him from the promise to Edwards. Failing in this, the puzzled and somewhat penitent patron put in Edwards as the old minister's assistant, half hoping that the now sapless "Dominie Sampson" might be accepted by the people for pity's sake. Alas! for the earl, the tutor proved so prodigious a failure that the little parish came to hate him, and the kirk became emptier than ever. Again the earl appealed to his ruthless brother: "John Edwards had been fairly tried and found wanting; would he accept this fact as sufficiently redeeming his promise to the unhappy tutor, which should never have been made, and agree to another plan?" This was, to ask their clansman, Dr. Duff, to accept the nomination to Marnoch, which had now become vacant, in the certainty that he would be unanimously called by the people under the Veto Act. General Duff heartily consented, and, let us hope, was inclined to provide for the old tutor at his own expense instead of at the spiritual cost of the parish.

On this the earl asked his own minister, $\mathrm{Mr}$. Grant, of Banff, to plead with Dr. Duff, to whom the nomination was offered as a mark of the earl's good will, as some recognition of his high deserts, as the only means of delivering the patron from a terrible dilemma and of preventing a local scandal; but, above all, as a sure bulwark against the tide of schism and anarchy which might sweep away the Kirk itself and destroy even its Bengal Mission. Dr. Duff was implored to be the Curtius who would thus close up the gulf for ever. It was all in vain. 
Poor Edwards was forced on the three hundred lieads of families and thirteen heritors against their solemn dissent, against the law of the Kirk and of the land till Parliament altered it, and against the rising clamour of the whole country. He was invited by only one heritor besides the earl and his brother, and one parishioner, "Peter Taylor, the keeper of the publichouse at which the presbytery were wont to dine." No man knew and no minister proved better than Dr. Duff that Marnoch, like Auchterarder and Lethendy, was but a symptom of a disease to be cured only by the vis medicatrix naturce of the case-by leaving the Church to the laws of Christ in word and conscience, a loyal ally of the state but independent in the purely spiritual sphere. Dr. Duff respectfully declined what was undoubtedly intended to be a liberal and generous offer. The earl replied in a letter expressing admiration of the consistency and self-sacrifice of the missionary. But the old companion of the worst sovereign England has seen, turned to the law courts, where a majority of the judges, to the grief of men like Jeffrey and Cockburn, helped him and his reverend presentee to drive every member from the kirk to worship God, like their forefathers in persecuting times, in a hollow in the winter's snow. With these three typical instances we dismiss such calls to home work.

How was not only the Church but all Scotland to be organized for the permanent and progressive support, by prayer and by knowledge, by men and by money, of missionary work in India? That was the problem which had occupied the thoughts of Duff on his homeward voyage, "when rocked amid the billows of a tempest off the Cape of Good Hope," and again as he paced the deck on the return of health. His resolution was formed before he landed, only to be intensified by the early indifference of the committee which his first 
speech had dissipated, and by the return of the fever which had fired his spirit anew. It was "the favourite plan of visiting and addressing all the presbyteries of the Church in detail "which had thus forcibly seized his mind, and had been elaborated and prepared for during the first six months of his recovery. Such a proposition, he told the friends of the India Mission in 1844, when its success had been established and the organization had to be renewed on a greater scale owing to the disruption, "was received in those days, even by the most sanguine, with grave doubts and fears as to its practicability, and by others with an expression of stark amazement. 'What!' was the ordinary exclamation, 'expect presbyteries of the Church, in their official presbyterial capacity, to assemble on a week-day for the express and sole end of listening to an exposition of the motives, obligations and objects of the missionary enterprise, and that too, with the ulterior view of organizing themselves into missionary associations!'-certain well-known presbyteries, both in the north and in the south, being usually named, in regard to which the realization of such a plan was felt to be the very climax of improbability."

From his own mind the experience of Irvine, and from the Church his Assembly speech, removed every doubt. Generally preceding Chalmers in the church extension movement at home, with a thoroughness and over an extent of country possible only in the case of one who devoted to it his whole strength and unique experience, Dr. Duff went far to anticipate the greatest triumph in Christian economics, the Sustentation Fund for the ministers. The parallel, the necessary balance and support of that fund, is the system of congregational associations under similar presbyterial supervision for the missionaries abroad. 
But the essentiai preliminary to all success had to be made known-foreign missions are of no party. They are the care and the corrective, the test and the stimulus of all parties in the Church. The missionary who, as such, takes a side in ecclesiastical warfare, may gratify his own personal bias, but he imperils the cause in which he ought to be absorbed. The missions of the Scottish Church, above all, originated in pure catholicity, and have, even through the disiuption, been directed by Christlike charity. Dr. Inglis, their founder, was a moderate by association and an evangelical in spirit, as we have seen. When he sought and found the first missionary he wrote to the most pronounced of the moderate party-"As to his side in the Church I have made no inquiry." And it will be well at this stage to ponder the fact, as the key to much of his future action, that that missionary thus early, alike in his friendly intercourse with and help to Dr. Bryce, in his loyalty to Dr. Inglis and Dr. Brunton, and in this statement of his ecclesiastical policy, declared the superiority of himself, because of his work, to all party. Thus he became the peacemaker, in one sense of the beatitude, at home, as in the higher sense his work in India of reconciling men to God won him abundantly the peacemaker's blessedness. He thus described the success of his first campaign of 1835-7, and the cause of that success. As a question of mere statistics he raised the annual income of the foreign missions scheme from $£ 1,200$ to $£ 7,589$ in 1838 .

"My journeyings among the towns and presbyteries of Scotland were soon commenced, amid various interruptions, of longer or shorter continuance, arising from ill health and other causes, till almost every town and district from the Solway Firth to the mainland of Orkney had been visited, and many of them more than once,-and almost every presbytery of the 
Church addressed and organized into a missionary association. Throughout these extensive and diversified visitations, I was received with equal kindness and attention by all classes and ranks in society-in the baronial residence of the nobility, and the cottages of the poor, by ministers and members of the moderate and evangelical divisions of the Church, as well as by leading ministers and members of the different dissenting communions. And why? For this chief reason, I have no doubt, among others, that no one knew me as a party man-no one being able to point his finger to a single overt act of mine which could fairly stamp me as such. Meetings of every description, public and private, Church and anti-Church, Intrusion and non-Intrusion, were held in all directions around me, with the frequency and the fulness of the showers of an Indian rainy season : and yet, up to the hour of my departure from Scotland, I never once was so much as present at any one of them. Everywhere, accordingly, was I received in my simple and single character as a missionary to the heathen, pursuing, with undeviating fixity of purpose, my own chosen and peculiar vocation. In this way regions and habitations were visited that had never been invaded by the sound of a missionary's voice before. The result was, that a great deal of new information was communicated, much sympathy and interest in behalf of India excited, and not a little of hitherto unbroken soil reclaimed for missionary purposes. Everywhere were large and liberal collections made, prospective obligations voluntarily undertaken, and permanent associations, presbyterial and congregational, special and general, duly formed. Ministers and other office-bearers, on both sides of the Church, were brought into immediate friendly and co-operative contact, on a theme wholly exempt from the intrusion of party jealousies, rivalries, and antagonisms, - a theme which savoured pre-eminently of the Cross, appealed to the most generous motives, and aimed at the promotion of the noblest ends. Already it was evident that a better understanding and better feeling was beginning to spring up between various purties, previously marshalled in mutual opposition; that these parties frequently greeted and recognised each other on more cordial terms, frequently visited each other on a more friendly footing, and frequently assisted each other, on sacramental and other occasions, in ways that promised to 
exert a mellowing and hallowing influence, alike on pastors and people. Amid scenes and experiences like these how could my heart be otherwise than glad? How could I help rejoicing in a growing process of convergency and assimilation? How could I but long, with prayerful earnestness, for the time, when 'Ephraim should not envy Judah, nor Judah vex Ephraim ;' but when all, merging the heats and tempers of partizanship in the divine amplitude of the Christian spirit, should unite, on the broad basis of a common faith and a common charity, in extending the empire of the Redeemer over the remotest wilds of heathenism."

Having settled his family in the old mansion-house of Edradour, within a mile of Pitlochrie, he recruited his energies there during June, 1835. Meanwhile the Rev. Dr. Gordon, as secretary of the committee, was putting in force the short Act passed by the General Assembly recommending all presbyteries to give Dr. Duff a respectful hearing at meetings called for the purpose, and to form a presbyterial association to create in each congregation an agency for prayer and the propagation of intelligence regarding the evangelization of the world. This Act had been drawn up by Mr. Makgill Crichton, of Rankeillour, in the back-room of the publishing house of Waugh and Innes, next the Tron kirk, to give practical effect to the enthusiasm created in the Assembly by the great speech, and had been unanimously passed.

Beginning with the presbytery of Meigle, the first in Strathmore to the east of Perth, Dr. Duff proceeded during the rest of the year in regular order to the north, zigzagging over Forfar, Arbroath, Brechin, Montrose, Aberdeen, the valleys of the Dee and the Don, Old Deer, Peterhead, and Fraserburgh; then west through Strathbogie, along the Spey, and through Banff, Elgin, and Forres to Inverness. At the last he spent a week, but he generally addressed three presby- 
teries, including the large congregations, every week. He then went northwards to the presbyteries of Chanonry, Dingwall and Tain, still in addition to these addressing large congregations. In the morning of the day on which he was to leave Tain for Dornoch, he was suddenly, while at breakfast in the manse of Dr. Macintosh (whose mother showed him all manner of motherly attentions, as he had known her brother, Mr. Calder, and others in Calcutta), seized with a fit of fever and ague. He was thus obliged to betake himself to bed, which he was unable to leave for three weeks. All the arrangements for meeting the eastern presbyteries of Sutherland and Caithness were overturned, and the only one that could be overtaken according to the old arrangement was that of Tongue in the Reay country. He resolved to proceed thither direct across Sutherland. A friend conveyed him to the manse of Mr. MacGillivray, at the lake Lairg, where he remained one night, and met there young $\mathrm{Mr}$. MacGillivray, minister of Strathy, half-way between Thurso and Tongue, who had come a distance of nearly a hundred miles to convey him to Tongue. There they arrived in the midst of a snowstorm. But the hearts of the people were warm. Nowhere did he meet with a more hearty reception. From Tongue he proceeded eastward along the coast of Thurso, stopping one night with Mr. MacGillivray to address his people. On that occasion one of the old peculiar race called "the Men" spoke a few words at the close, and as he was speaking down came a heavy pour of rain which pattered very strongly against the windows. For a moment the speaker paused, and looking gravely at the people said to them with much earnestness in Gaelic: "My brethren, they are the heavens that are weeping over the sins of the people," but in Gaelic the phrase was much more expressive than any trans. 
lation of it into English can be. After addressing the presbyteries of Thurso, Wick, and Dornoch, as well as large congregations connected with these places, Dr. Duff returned to his temporary home in the vale of Athole in order to recruit from the exhaustion of six months incessant itinerating and public speaking. How thoroughly even the most "moderate" presbyteries did their work on this occasion is seen in the "Brief Exposition of the Church of Scotland's India Mission," a well-written and eloquent appeal of thirty-five pages by the presbytery of Ellon, for the formation of a Foreign Mission Association in every parish as giving to the interest taken in the diffusion of the gospel a fixed and permanent character.

If Dr. Duff was surprised by the enthusiasm which he called forth in his first tour, the result of the second exceeded even that. For, to the fame of his Assembly speech there was now added the bruit of his eastern and northern triumphs. And he opened the campaign of 1836 in his own county of Perthshire. Repeated attacks of his old fever, in spite of the occasional retreat to Edradour, forbade the physicians to allow him to think of returning to India. But, as may be seen from this extract from an official narrative of his proceedings sent to the committee at the close of 1835, his heart was ever in India :-

"As nearly a twelvemonth has passed by since I reached my native land, I naturally begin to look with a longing eye towards the East. Summer is the best season for leaving this country. But if it be resolved that I set off next summer, medical opinion conspires with dire experience in enforcing on me the conviction that the intervening period spent in almost absolute repose would be little enough so to recruit my frame as to entitle me, with any reasonable prospect, to brave 
znew the influence of a tropical climate. On the other hand much, very much, might yet be done in this our native land in behalf of the mission. Unless it be vigorously supported at bome little can be done abroad. But there is a disposition to support it at home wherever its claims are freely and intelligibly made known. The experience of the last few months, I think, has amply confirmed this assertion. Of course the grand advantage (and the only one to which I lay claim) that I possess in advocating the claims of the mission at home, is one that cannot be communicated to others, even that of having been on the field of labour, and having been an eye and ear witness of all that I happen to describe. It is this circumstance mainly, I must presume (for nothing else of an advantageous nature am I conscious of possessing beyond my fellows), that has made our brethren and the members of our Church generally muster everywhere in such numbers and listen with such marked attention and resolve with such admirable unanimity. It was my own impression, months ere I landed on these shores, that good might result from visiting the presbyteries of our Church. But that impression has been deepened in a tenfold degree by the experience of the last four months, i.e. if professions without number do not turn out (which God forbid) like Dr. Chalmers's exuberant shower of promises. About a third part of the presbyteries have now been visited, and clearly the other two-thirds could not be visited before next summer, or if so such visitation would leave me in a condition the most unfit for resuming my labours in the East, but it seems most desirable that all the presbyteries should be visited. What then is to be done? As for myself I am in a strait between two. But after having thus stated the case I leave the matter entirely in the hands of the committee." Dr. Macwhirter 
settled the matter for both by peremptorily deciding, on medical grounds, in favour of a less active and exciting visitation of the presbyteries.

Very vividly are the impressions of the first visit of Dr. Duff to Perth pictured by two of his audience at the time, Mrs. Barbour, then a child, and her mother, Mrs. Stewart Sandeman, of Bonskeid, in the neighbourhood of Moulin. These are some of the lines written by Mrs. Sandeman in 1836 upon Dr. Duff :-

"He crossed o'er our path like an angel of light, The sword of the truth in his grasp gleaming bright;

O'er mountain and valley unwearied he flew Imploring our aid for the poor lost Hindoo.

"The rich gorgeons East with its dark Indian grove Was the land that he pled for-all pity and love; But we caught the swift glance and the dear mountain tone, And claimed him with reverence and pride for our own.

"Yes! dark Ben-i-vrackie, all rugged and wild, And fair vale of Athole, ye welcome your child, For oft have his thoughts turned in fondness to you, While he toiled for the soul of the darkened Hindoo.

"And shall we not aid him with heart and with hand To ope fountains of truth in that desolate land? Nor break the witched charm that he over us threw While in anguish he pled for the erring Hindoo."

"The arrival of Dr. Duff in the county town of his native Perthshire was a memorable-event to most of the dwellers in it. It was doubly memorable to the children who got a holiday to go and hear him in the East Church on a week-day. Some days before, the carriage had been watched as it conveyed the invalid missionary to the crescent facing the North Inch, and stopped at the house of the Rev. William Thomson, for whom he was to preach in the Middle Church. Reports of his suffering state had come before him. 
Mrs. Stuart, of Annat, then residing in Edinburgh, had been at the communion in Lady Glenorchy's church. She came home enraptured with the tableservice, at which a stranger had presided. His voice had seemed like one from heaven, and be looked so ill, as if he might have passed away while he broke the bread. It was Dr. Duff who had arrived from India.

"It was no wonder that the deep galleries of the old Middle Church of St. John's, Perth, always full, were on that morning crowded. Even the seats behind the huge pillars were eagerly seized. The text was, 'Be not conformed to this world.' While the preacher cut right and left, root and branch at the worldliness in the Church of Christ, he described how men and women carried it into God's house, and could be seen stepping down the aisle with a look so proud as might make an archangel blush. Next came the week-day address on the claims of India. Mr. Esdaile, the scholarly minister of the East Church, followed by the presbytery and other ministers, accompanied Dr. Duff to the pulpit steps. Some had made a tedious journey to be there. Even the children in the multitude that day assembled were breatbless listeners. The gaunt figure in the pulpit, soon rid of the gorn, was seen beneath the coloured window which was wont to come between little people and weariness when Mr. Esdaile's erudite and polished discourses went beyond them. And now the eloquent descriptions of the faroff land began. Snow-peaks, dense forests, aromatic gardens and Ganges waters were the background. The hideous image of idolatry arose before the mind's eye like the monster of Nebuchadnezzar's vision, Brahmans, falseers and soodras in thousands swarming at the base. Each arrowlike sentence of appeal for help was barbed with reproach to the selfish Britons who had come home rich without doing anything to enlighten 
the natives of 'poor, pillaged, ravaged, unhappy India.' When all was over the missionary sank back exhausted, and had to rest half-way down the pulpit stairs. One at least of the young who had heard him had to seek shelter in bed on returning home, to hide the marks of weeping, ready to join on the morrow in the project of a school companion whose emotions had taken the practical shape of a penny a week subscription."

Dr. Duff's host, on this occasion, was the Rev. Dr. William Thomson, whose portly figure and exalted character used to strike him with awe when he was a boy at Perth Academy. In his own field of genial scholarship and active philanthropy he was worthy of his more famous brother, Andrew Thomson of St. George's. The tremendous strides of the missionary, as he walked with her father to the top of Kinnoul hill, so alarmed the youngest daughter, now Mrs. Omond of Monzie, that she was glad when he stopped at the Tay bridge to take a long fond look of the hills among which his father's cottage lay. When, in 1863, the old man passed away at the age of ninety, Dr. Duff, then still in India, recalled in a public letter the long career of Dr. William Thomson, and declared that his had been "one of the happiest, most genial, and alike to head and heart most exhilarating domestic circles in Christendom."

It was during this Perthshire tour that Dr. Guthrie, following hard on Dr. Duff's track in the cause of church extension, found this trace of him at Abernyte. Mr. Wilson, the minister of the parish, had as his assistant that James Hamilton who became an accomplished naturalist and Edward Irving's successor in London. But Wilson himself was an opponent of Sir Isaac Newton in the law of gravitation. It grieved him that his Church's first missionary should dream of 
subverting Hindooism by a science quite as false as the cosmogony of the Veds. Dr. Guthrie attempted to reason with the animated fossil, and then pretended to be so far convinced as to ask most meekly how it is that the people of the antipodes do not drop off into boundless space. "Well sir," said the simple opponent of Sir Isaac Newton, "they keep on just as the flies do which you see there walking along the ceiling." Some of the a priori objections to Dr. Duff's evangelistic system of education were quite as well founded.

In two instances only did the Indian missionary meet with rudeness. One occurred under circumstances which have caused the event to be traditional in the place. Appealed to long after for the facts, he thus told the story. The presbytery of Dunbar had been summoned to meet in the parish kirk of the town. Dr. Duff was received the evening before the meeting under the hospitable roof of Mr. Sawers. On setting out to visit the minister of the kirk, as was his first duty, he was gently warned that his reception might not be very cordial. The Rev. Mr. Jaffray, be was told, was notoriously hostile to foreign missions generally, and was by no means reconciled to those of his own Church. This did not deter Dr. Duff, whose duty it plainly was to show courtesy to the man in whose kirk he was to address the presbytery and the people. After some hesitation the servant admitted him, and he followed her to the study so closely that further denial was impossible. Mr. Jaffray stood up, and glaring at the intruder with fury, shouted out in tones heard by the passers-by in the street outside, "Are you the fanatic Duff who has been going about the country beguiling and deceiving people by what they choose to call missions to the heathen ? I don't want to see you, or any of your descrip- 
tion. I want no Indiąn snake brought in among my people to poison their minds on such subjects; so as I don't want to see you the sooner you make off the better." Dr. Duff stood calm and imperturbable for a little, and then, breaking the silence, said that he had come merely to show him courtesy as the minister of the parish and an ordained minister of the Established Church, as both of them were. As he must be aware to-morrow the meeting of presbytery was to be held in his church, he, Dr. Duff, thought it only due to him to show this tribute of respect and courtesy. With permission therefore Dr. Duff very briefly would tell him the nature and object of his visit to Dunbar under the sanction and recommendation of the General Assembly. $\mathrm{He}$ did so very briefly because he saw in Mr. Jaffray's countenance that the churl was all the while in wrathful agony.

When Dr. Duff ended, he said he had nothing more to explain and would now retire. "By all means," the reply was, in a surly tone, " the sooner the better. I never want to see your face again on earth. I was no party to the meeting to-morrow. The presbytery had a perfect right to fix on my church; but as for me, I had nothing to do with it; I shall not go near the meeting, for I hate the subject, and might almost say the same thing of him who has been the means of calling such a meeting to disturb the feelings of my people and introduce what may be new strifes and divisions among us." Dr. Duff, in a single sentence, said ho hoped and trusted it would turn out otherwise, since the blessed Saviour's command was, "Go into all the world, and preach the gospel to every creature," and the present was but a humble attempt on the part of the Established Church of Scotland to obey this parting and imperative commission. All this time both were standing in the middle of the floor; so Dr. Duff, respect- 
fully bowing, bade him good-night, and retired to his congenial quarters. That evening Dr. Duff said nothing, except, in answer to a question, stating in general terms that the warning $\mathrm{Mr}$. Sawers had given had not been in vain. Next day, however, he was everywhere met by parties personally unknown to him, who condoled with him on the strange reception given to him by their minister. "The truth is," they said, "we expected nothing cordial, but we never dreamed that he would stoop to snch rudeness." After this Mr. Jaffray very generally throughout the bounds of the Church, when this remarkable incident became known, went under the name of the Brahman of Dunbar. The intention was to indicate his barbarous rudeness, but the greatest injustice was thus in ignorance done to the Brahmans of India, more particularly the learned and studious class, who are among the most courteous and gentlemanly persons to be met with.

By this time the effect of Dr. Duff's work in Scotland had spread across the border, influencing churches and societies in England. When in the midst of his organization of associations in Perthshire, he was pressed by many and repeated invitations from the great missionary and religious societies in London to address them in the coming month of May. Even those who had most ignorantly objected to his Assembly oration of 1835 , that it did not represent the operations of other Christians in India, had by this time discovered, alike from his provincial addresses and the representations of their agents in Bengal, the catholicity of his spirit and the extent of his zealous co-operation with all the Protestant missionaries in Calcutta and the neighbourhood. Especially was this the case with the Church Missionary Society, the noble evangelical organization of the 
Church of England, whose representatives in Bengal, Dealtry, Corrie and Sandys had been his most intimate fellow-workers. His response to that society's earnest appeal to address its annual meeting in May was the beginning of a relation which, as we shall see, became closer and more loving on both sides till the end. Never before had the directors deemed it expedient to go out of their own episcopal circle to find speakers, till Dr. Duff was thus enabled to return, on a wider scale, the kindness of Dialtry and Corrie to himself when he first landed in Bengal. When the meeting was held in London he found himself on the platform seated between the Bishops of Chester and Winchester. When the latter had spoken the young Presbyterian apostle rose, and so addressed them that the interest and emotion of the vast audience continued to increase till he sat down amid a tempest of enthusiastic applause. We have no report of this effort beyond its effect, which the Bishop of Chester indicated when, following Dr. Duff after a long pause, he declared with characteristic gravity that he had waited until the gush of emotion excited by the preceding speaker had been somewhat assuaged. When all was over, among others the godly Mr. Carus, one of the deans of Trinity College, Cambridge, introduced himself to Dr. Duff, and at once exacted the promise that the missionary would accompany himself in a day or two on a visit to the University.

Other circumstances apart, the peculiar interest of this visit to Cambridge lies in the meeting for the first and last time of the aged Simeon and the young Duff. Simeon was within a few months of his death, but even after half a century's labours for the Master, in England and Scotland and for India, he was apparently in health and vigour. He and Dr. Duff had what the latter afterwards described as " a very prolonged 
sederunt." He was full of questions regarding India and its missions, for which he had done so much all that time. And we may be sure that, among the other topics which occupied that memorable conversation, the Moulin revival was not forgotten. We have already traced the spiritual ancestry of Duff to Simeon, from the journal of the latter, written in 1796, when the events occurred. The record of them, or the talk about them forty years after by the venerable saint and his own son in the faith, the evangelical Anglican and the evangelical Presbyterian, it is now possible for us to recall from Duff's talk afterwards.

What during the conversation gave Simeon such profound interest in the Moulin revival of 1796 was the remembrance of his own share in the quickening. His host, Mr. Stewart, the parish minister, was then a comparatively young man, an excellent and accomplished scholar, but without any evidence of true piety. He was of a frank and cheerful disposition, and was a great favourite with the people, for whom he had always a kind word. His life, as written by Dr. Sieveright, of Markinch, shows how by degrees he became unhappy, from the conviction that there was something real in Christianity which he did not possess and had not discovered. The exceeding honesty of his intellectual nature showed itself thus, as one present told Dr. Duff. Mr. Stewart had read the preliminary psalm at public worship in the church on the Lord's-day, and was about to give out his text, when he leaned over the book board, and looking round with a saddened, piercing eye on his congregation, he said to them in substance: "My brethren, I am bound in truth and faithfulness to tell you that $I$ feel myself to be in great ignorance and much blindness on the subject of vital religion. I feel like one groping in the dark for light, and as yet I have found none. But I think it right to tell you, 
that if God in mercy will give me any measure of the true light, joyfully shall I impart the same to you. Do you therefore, all of you, pray God fervently that He may be pleased to bestow upon me the true light, or such portions of it as He may deem fit for me."

An announcement of so novel and startling a kind, indicating such simplicity and godly sincerity, could not but produce a profound sensation. The news rapidly spread, not only through the parish but through the surrounding country. One of the consequences was that many even of the most careless and ungodly were wont to go every Lord's-day to church in the expectation of hearing that the minister had found what he called the true light. Still weeks and months passed without any discovery being mado to him. At last it so happened that Mr. Simeon, of Cambridge, and the Rev. James Haldane, of the Tabernacle, Edinburgh, had arranged to make an extensive tour through the north of Scotland, preaching the gospel as they might find opportunity. On a Thursday they had arranged from Dunkeld to visit Blair-Athole, about twenty miles distant. They had to stop at Pitlochrie, which is about half-way. At that time there was a small country inn there. On arrival they told the innkeeper that as early as he could manage it they wanted a couple of horses to take them to Blair-Athole. "Na, na," said the innkeeper, "this is our fast day, as the sacrament is to be held next Sabbath, and we regard the fast day like another Sabbath, and we do not hire horses or vehicles on the Lord's-day." " Well," said Simeon, "I suppose there is worship in the parish church to-day ?" "Oh, yes," said the innkeeper, naming the hour. "Well," said Simeon, "though this in one respect is a disappointment to us, it may be that in some other respects, as yet unknown to us, God may have some gracious 
design in it, so let us go at once to the English worship at Moulin." Towards the evening of the day, after all the services, English and Gaelic, were ended, Simeon and Haldane resolved to call at the manse and see the minister, who received them with great heartiness. After some converse Mr. Simeon, from his sage, spiritual experience, could not but notice there were internal workings in the soul of Sterwart which to him looked like the incipient influence of divine grace. Mr. Stewart was greatly refreshed by Mr. Simeon's converse, and in parting with both in the evening he said to them, "You can see everything that is worth seeing in and about Blair-Athole by Saturday afternoon;" so he implored them both to come to the manse on Saturday evening, attend the church on Sabbath, and partake or not partake, as they thought proper, of the sacranient. Mr. Stewart said that as minister of the parish he would be expected to preach what the Scotch were in the habit of calling the "action sermon"- sermon before the administration of the sacrament-but that on sacrament Sunday they had always public service in the church in the evening, as the people's hearts were then surcharged with feelings of love and pious emotion. That sermon Mr. Stewart asked Mr. Simeon to preach. Simeon agreed, and it is very remarkable how that sermon was blessed of God as the signal instrument of opening Mr. Stewart's ejes to discern the true light of the everlasting gospel.

His own declaration was, that about the middle of the sermon Mr. Simeon, who had evidently studied his case and endeavoured to adapt as much of the discourse as was practicable to it, uttered a few sentences which to Mr. Stewart looked like a revelation from heaven. His own significant expression was, that it seemed as if the dense cloud canopy which had bitherto interposed between his soul and the vision of God in Christ 
reconciling a guilty world to Himself, had suddenly burst asunder, and through the chink a stream of light had come down direct from heaven into his soul, displacing the darkness which had hitherto brooded over it, filling it with light, and enabling him to rejoice with exceeding great joy. He was wont, also, to add, that in spite of partial obscurations afterwards, this light never wholly left him, but continued to animate, cheer and guide him through all his ministerial and other labours. On the following Lord's-day Mr. Stewart was enabled joyfully to announce publicly from the pulpit, that the light which he sought for and waited for from heaven had at last dawned upon him and filled his soul with gladness; he would therefore proceed Sabbath after Sabbath to give out as much of it as he could to his own people and others who might choose to be present. He then commenced a series of discourses on the 3rd chapter of St. John's Gospel, which awakened, aroused and enlightened numbers of the people. Parties were wont to come every Sabbath from all the surrounding parishes, so that the work became very extensive, and proved a mighty revival, in which scores of the previously careless, indifferent and godless became genuine converts to the truth as it is in Jesus, and continued so all their days. Yea, instead of diminishing, their light went on increasing and abounding. However humble in their circumstances, however illiterate, their souls became replenished with the truths of the Bible, so as to become burning and shining lights to all around them. All this will account for the deep interest felt by Mr. Simeon when Dr. Duff called upon him, as the father and mother of the missionary when young and unmarried came more or less under the arous. ing influences of the great revival. About three or four months after this Mr. Simeon was called to his 
eternal reward, but though he rests from his labours, his works, in many of their blessed and fruitful spiritual consequences, do still follow him. Such is substantially Dr. Duff's account of what he had heard of the Moulin revival, and of what Simeon and he had talked over in Cambridge. The Baptist Carey, the Anglican Simeon, the Moderate Inglis, and the Evangelical Chalmers, united with such Congregationalist contemporaries as Urquhart and Lacroix to link Duff into a truly apostolical succession, divided by no party and confined to no sect.

As the guest of Carus at Cambridge, Dr. Duff occupied the rooms in which Sir Isaac Newton made many of his most remarkable discoveries in optics. The old St. Andrews student revelled in associations in which no college in the world is more rich. For Trinity, which Henry VIII. founded and his daughters enriched, had been the nursery not only of the Church's most learned prelates and theologians, but of Bacon as well as Newton, of Cowley and Dryden and Andrew Marvell. When dining daily in the common hall with the professors and students, he had much converse with Whewell, who was master from 1841, when he succeeded Christopher Wordsworth, to 1866 when he was followed by "Jupiter" Thompson, the present master. But what interested him most of all, after the living Simeon, was the collection of the Milton MSS. in the museum of the college. There he saw the list, in Milton's own hand, of the hundred titles, or more, which the poet had jotted down on returning from Italy, in his thirty-first year, as possible subjects of a great English poem. There "Paradise Lost" appears at the head of them all, and also four drafts of it for dramatic treatment," the drama to open, as the poet's nephew

* See Professor Masson's perfect Globe Edition of The Poetical Works of John Milton (1877), page 11. 
Phillips tells us, with Satan's speech on first beholding the glories of the new world and the sun, as now given near the beginning of the fourth book of the epic.

Ever in the midst of his absorbing talks with Simeon and Carus about missions, Dr. Duff was constrained by the genius loci to think of Milton. When walking by the Cam, on one occasion, he expressed surprise that no regular Cambridge student had then offered his services as a missionary. Carus, in reply, drew his attention to the exceeding beauty of the spot; to the loveliness of the grounds and their adornments; to the banks of the Cam with their grotesque variety of flowers, the willow trees overhanging the stream, the umbrageous shade cast by other trees on the footpaths along the lawns, seats to invite the student to enjoy his favourite books; to the exquisite order in which all things were kept. All this, said Carus, tended insensibly to act on human nature, and produce an intensely refined and luxurious state of mind, with corresponding tastes and predilections from which it would be difficult to wean the student so as to induce him to become a voluntary exile to distant shores teeming with the abominations of heathenism. The remark, Dr. Duff replied, had some force in it, in the case of the old nature. But this ought not to present difficulties to the child of God, who professed to act by faith and not by sight. Whoever was resolute of purpose as a son of God, would find divine grace more than sufficient to wean him not only from the academic illusions of Cambridge, but from all the world besides. But then, turning to the river at their side, he exclaimed in the lines of the exquisite Lycidas, the memorial poem which Milton wrote on the death of Edward King, his fellow-student at Christ's College:- . 
"Next, Camus, reverend sire; went footing slow,

His mantle hairy and his bonnet sedge,

Inwrought with figures dim, and on the edge

Like to that sanguine flower inscribed with woe.

'Ah! who hath reft,' quoth he, ' my dearest pledge ?' "'

At that time Mr. Carus could not venture to call a public missionary meeting in the college, but the Mayor presided over a great gathering of students and citizens in the town-hall, whom Dr. Duff addressed at length on India and its missions. From Cambridge he went to Leamington, where he gained some advan. tage from the treatment of the then celebrated Dr. Jephson. Having avoided the excitement of the General Assembly of 1836, he thus spent the summer in England. But on his return to Scotland in autumn, to complete his organization of the presbyteries and congregations, he was sternly ordered by the physicians to rest at Edradour. Rest for him was impossible. He induced them to wink at occasional raids, made for three or four weeks at a time, in different directions from that centre. Thus the months passed till the General Assembly of 1837.

During all his wanderings north and south, Dr. Duff kept up a close correspondence with his colleagues, Messrs. Mackay and Ewart, in Calcutta, and with other friends of the mission there. He was a keen observer of public affairs in the closing days of Lord William Bentinck's administration, and the opening promise of that of Lord Metcalfe, whom the jealous Court of Directors refused to appoint permanent Governor-General. Of how much that was most brilliant and abiding in these times could we not say that he had been a part? How he explained to the English public the exact meaning of Lord William's educational minutes of 1835, in his "New Era of the English Language," we have told. The following extract 
from an official letter to the committee, gives us his impressions of the other great triumph in the establishment of the Bengal Medical College:-

"Edradodr, 13th July, 1835.

"I have just received a letter from an intimate friend in Calcutta, Mr. J. Nelson, attorney of the Supreme Court, and now a member of our corresponding board. He writes :-

"'You will frequently have heard that the school is doing well. Within the last few days a prospect has been opened up likely to be very beneficial to it. I allude to an entirely new construction of the medical school with which Dr. Tytler was connected, which has been placed under Dr. Bramley, who is to receive boys from the various seminaries, qualified by their knowledge of English to become pupils for education in medicine. He states that in the formation of his plan, he particularly looked forward to our seminary for a supply, and at a visit he made to it the other day he found a number of boys most willing to go to him. I think there can be no differences of opinion as to the advantages likely to accrue by this opening for the young men. It is true that the primary object we have in view is the endowing them with a knowledge of Christianity, and sending them forth as teachers and preachers amongst their benighted countrymen; but it is easy to perceive that for many years persons so sent forth would require to be supported by our funds, and we have not the means of doing so except to a limited few. Besides, it appears to $\mathrm{me}$ to be highly valuable to have a portion of native Christians as laymen, interspersed among the bretliren, particularly in such a respectable character as that of a doctor ; for it is not intended that they shall, when qualified, be drafted out to the army. On the contrary, they are to receive the education and thereafter to have a free control in the exercise of their knowledge and talents, in such way and manner as they may respectively think proper. The jail of the Court having been vacated, Dr. Bramley has applied for it, and I believe I may say that Government have agreed to give it for a small rent, one portion to be occupied by our school, and the other by his 
medical seminary, whereby such of our pupils as fancy medicine will be completing themselves in the higher branches of education, at the same time that they are receiving medical instruction.'.

"Of the intention of Government to remodel the old native medical institution in Calcutta I was fully aware upwards of two years ago. Dr. Tytler, at the head of it, and his coadjutors were of the old school of orientalists, who strenuously upheld the necessity of communicating all European science to the natives through the medium of the learned languages of the East. The decisive experiments of the last few years in Calcutta have tended entirely to explode this opinion, and leave it a refuge only in the minds of a few of the old orientalists. In remodelling the medical school, the grand controverted question was, whether, as heretofore, the knowledge should be conveyed to Mussulmans in Arabic and Hindoos in Sanscrit, or whether it should not be conveyed to both through the medium of English. A Government committee was appointed to receive and examine evidence from all quarters, and then submit a formal report to the supreme Government. The three most active men in this committee were Mr. Trevelyan, the deputy political secretary; Dr. J. Grant, the writer of the account of the last examination of our Institution, and Dr. Bramley. Being all intimate friends of my own, I was from time to time apprised of the progress and results of their inquiries; to about fifty questions relative to the state and prospects of English education in Bengal, I gave a lengthened reply in writing. Before I left India this report was finally completed, and being faroured with a perusal of that part which related to the question of general education, I had the satisfaction to perceive that the new views on this subject were recommended in such a way as to insure 
their adoption on the part of Government. And glad I am, for the sake of our Institution and for the real welfare of India, that this has been the consummation. The superintendence of the medical school being taken from Dr. Tytler, the champion of antiquated opinions, and given to Dr. Bramley, the enlightened supporter of sounder views, furnishes a guarantee of indefinite future good to India, as it is the test of the triumph of enlightened principles and measures among the powers that be . . Two Calcutta letters have just reached me by the morning post, the one from Mr. Trevelyan detailing the steps relative to the medical institution, the other, consisting of not less than four sheets, from Dr. Bryce. 'I'he doctor seems really to be most enthusiastic in our cause."

\section{"London, 22nd June, 1836.}

"Mr Dear Eirart, - I cannot possibly describe to you the intenseness of interest which our mission now excites in our native land. The eyes of all Scotland are now upon you. Oh, that God in His mercy would pour out His Spirit and seal home the truth to the hearts of numbers, yea, thousands of the perishing heathen! I had once cherished fondly the hope that this summer I would be retracing my steps to India. This, however, I find to be an impossibility; the truth is, that the labours at home, into which I was impelled for the sake of arousing the Christian public, have retarded the progress of my recovery, and reduced me to the lowest state of exhaustion. From this it will require some time to recover, and yet my work at home is not ended. The only thing that reconciles me to the detention in my native land, is the assured fact that God bas been pleased to employ me as an humble instrument in stirring up the slumbering zeal of our Church, and that the instrumentality has 
been crowned with a success which I never, never, never anticipated! Thanks be to God for all His undeserved mercies.

"I now understand the mystery of Providence in sending me from India. What between vile politics and fierce roluntaryism our canse was well nigh being entirely engulfed in oblivion. At first I could scarcely get from any one or in any place a patient hearing. Now, if I had a thousand tongues, they might simultaneously be raised in a thousand pulpits. 'The spirit is willing,' but, alas, 'the flesh is weak.' Pray for me-that after having left a flame burning behind me, I may be speedily restored to you. Yours affectionately,

"Alexander Duff."

Dr. Duff did not leave London, on this occasion, without spending a forenoon with Lord William Bentinck. After breakfast the two philanthropists enjoyed the fullest and freest converse regarding the conduct and policy of the Government in India, past and present. Reliered of the responsibilities of GovernorGeneral Lord William was able to criticise most frankly the anomalous constitution of the East India Company, of the Board of Control created to enable the Crown to check and overrule the Court of Directors, and of the administration in India itself in all its branches. The critic commended some institutions and persons, but exposed the faults and weaknesses of many more. Of that priceless experience, as of the still riper knowledge which Dalhousie and Lord Canning took with them to a premature grave, there is no detailed record. Rulers stumble on to-day repeating the mistakes of their greater predecessors and dreaming that their statesmanship is new because they are blind to the past.

Whilst the conversation was still fresh in his mind, 
Dr. Duff wrote down a very full and minute statement of the whole, which, as a curiosity, he sent to the Foreign Missions Committee.* One thing, however, was never effaced from his memory: Lord W. Bentinck with great emphasis said that some believed the Government in India was an absolute irresponsible despotism. Others were equally strong in the belief that the Court of Directors was the originating and directing power. Others again were as strongly convinced that the real power lay with the President of the Board of Control, with the British Parliament at his back. But, he added, one thing that struck him, and of the truth of which he had the amplest experience, was this, that in the office of the President of the Board of Control the chief secretary, through whose hands all official documents were sent out and sent home, for a long period-between forty and fifty years-exercised a power to which no President of the Board of Control, no Director, no GovernorGeneral or any other responsible official could pretend.

Lord William Bentinck soon after addressed this letter to Dr. Duff:-

"Frankrort, August 27th, 1835.

"Dear Sir,-I am confident you will excuse my seeming uncourteous return for your very kind letter, when I assure you that the weakness that I brought with me from India, and greatly increased by all the excitement, fatigue and bustle consequent upon my return, completely incapacitated me for all business and exertion, and it is only here and at Bruxelles that a day of leisure and quiet has given me an opportunity of offering this explanation to many friends whose

- This letter is not among those most kindly copied for us from the records of the Established Church of Scotland. 
letters I have been equally compelled to neglect. Lady William begs that I will express also her acknowledgments for your obliging inquiries. She is, I am sorry to say, a greater invalid than myself. We have been both advised to take the mineral waters of Germanyshe, those of Schwalbach in Nassau, and I, those of Carlsbad in Bohemia. My health has much improved since I left London.

"I am much gratified to hear of your successful operations in Scotland. It must be the result of great personal exertion alone, for though $I$ have had ample reason to know the indifference and apathy that generally prevail respecting all matters connected with. India, yet even with all this experience I was not prepared for the feeling of dislike almost with which any mention of India is received. But this conviction of a sad truth, this disgraceful proof of British selfishness ought only to have the effect of exciting those deeply interested in the moral and religious welfare of the people of India to renewed efforts in their behalf.

"I have always considered the Hindoo College as one of the greatest engines of useful purpose that had been erected since our establishment in India; but that institution, in point of usefulness, can bear no comparison with yours, in which improved education of every kind is combined with religious instruction. I will not prolong this letter further than to say that I cannot be more gratified with any man's good opinion than by yours, and wishing you health and happiness, I remain, dear sir, your friend and well-wisher,

“W. Bentinck."

This, the greatest of the Bentincks, who thus expresses something like shame at a degree of English apathy to India still prevailing in spite of warnings like the first Afghan war and the Mutiny for which 
that iniquity was the preparation, died four years after, having represented Glasgow in the House of Commons. Born in 1774, he was sixty-five years of age when his ripe experience was lost to a country and a ministry which preferred to the wise Metcalfe a place-hunter like Lord Auckland. But Heaven takes vengeance on a land for preferring the political partisans of the hour to its truly good and great statesmen. The equally noble Lady William, renowned in the East for her Christian charities, was the second daughter of the first Earl of Gosford, and survived her husband till May, 1843. This great Governor General's epitaph was written by Macaulay, in the inscription which covers the pedestal of the statue erected opposite the town-hall of Calcutta by grateful natives and Europeans alike :- “To William Cavendish Bentinck, who during seven years ruled India with eminent prudence, integrity and benevolence; who, placed at the head of a great empire, never laid aside the simplicity and moderation of a private citizen; who infused into Oriental despotism the spirit of British freedom; who never forgot that the end of government is the welfare of the governed; who abolished cruel rites, who effaced humiliating distinctions, who allowed liberty to the expression of public opinion, whose constant study it was to elevate the moral and intellectual character of the Government committed to his charge, this Monument was erected by men who, differing from each other in race, in manners, in language and in religion, cherish with equal veneration and gratitude the memory of his wise, upright and paternal edministration." 


\section{CHAPTER XII.}

1837-1839.

\section{FISHERS OF MEN.}

Effect of First Assembly Speech in Drawing Men.-Rev. John Mac. donald gives Himself.-M'Cheyne almost Drawn.-Glasgow supplies James Halley.-The Letters of Principal Macfarlan and Dr. Duff-Dr. Coldstream and Medical Missions.-John Anderson gives himself to Madras.-Followed by Johnston and Braidwood.-Drs. Mnrray Mitchell and T. Smith.-Stephen Hislop.Duff's Great Speech in Exeter Hall.-Spiritnal Destitution of India.-Indignant Satire on the Church's Apathy.-The Calculns of Eternity, and the Arithmetic of Time.-Missionary sacrifice in the Light of Christ Himself.-General Assembly of 1837.-Duff's Vindication of the Mission.-The two bigotries, of Infidelity and an unwise Pietism.- Native Apostles.-Duff appeals to Posterity. - Mistake of the Indian Presbyteries in the Training of Native Missionaries.-Dr. Macwhirter's Command.-Prize Essays on Foreign Missions.-Dr. Chalmers and the position of the Kirk in 1839.-Letter to Dr. Ewart.-Ordunation of Dr. T. Smith.Epistle to all Young Theologians. - Speech on Female Education. -Lectures and Book on India and India Missions.-Farewell to the General Assembly of 1839.-The Press.-Personal References. - Gifts for the College Building, Library and Scholarships.Duff pleads with Thomas Guthrie to go to India.-Dr. Chalmers endorses Duff's System, and acknowledges his Christian Economics.-The Farewell to Moulin and to the Children.

In the two and a half years after his return home at the beginning of 1835 , convalescent from the dysentery of Bengal but subject to the recurrence of its jungle fever, Dr. Duff had nearly completed his work of organization. Only the fervour of his zeal, and the power of recovery from exhaustion due to a splendid physique which marked his whole life, had enabled him to visit and address seventy-one presbyteries and synods and hundreds of congregations all over Scotland. This he had done during the rigours 
of winter and the heats of summer, when as yet the canal boat, the stage-coach, and the post-carriage were the most rapid means of conveyance. Trice he had visited London and some of the principal cities in England on the same mission. But that mission was not merely or ultimately the establishment of associations to collect money, nor even the diffusion through the Churches of a missionary spirit. These were but means to the great end of discovering and sending out men of the highest faith and scholarship to carry on the work he had begun in Bengal, to extend it to Madras, and to strengthen Bombay. For, with his delighted concurrence, the General Assembly of 1835 had received under its superintendence the Scottish Missionary Society's stations in Bombay and Poona, then under the care of Dr. Wilson, Mr. Nesbit and Mr. J. Mitchell. The Kirk's Bengal Mission, with its one missionary of 1829-31, must, according to Dr. Duff, grow into the India Mission, to christianize the progress which was radiating out from all the great English centres in the East.

Hence the most real and fruitful result of his first Assembly speech and of those which followed it, in Scotland and in England, was in drawing men to give themselves to India. The whole religious biography of the former country relating to that period is coloured by his influence or bears traces of his persuasive power. We have already told how his early visit to the London presbytery had converted the Rev. John Macdonald from an opponent of his system into such an advocate of it that the minister of Chadwell Street, Pentonville, threw up his home charge and took his place beside Mackay and Ewart in Calcutta. Son of that Dr. Macdonald of Ferintosh, who was worthy of the name he bore, of "apostle of the Highlands," John Macdonald published a "Statement of Reasone 
for Accepting a Call to go to India as a Missionary," which, as followed by his self-sacrificing life thereafter, was the most powerful testimony to the cause Dr. Duff had yet called forth. No one can give more than himself; no gift to any cause can be more precious than that of the whole spiritualised nature of a man who is in earnest to the death, as John Macdonald proved to be. In Macdonald Dr. Duff early saw, and found for the ten years of the new missionary's Indian experience, an intense spiritual force to give increased evangelistic efficiency to the Calcutta college. "Your special and peculiar vocation," he wrote to his new colleague before sending him forth, "would be to impart, through the blessing of God's Spirit, a spiritual impression to the minds of scores that have already become dispossessed of Hindooism, as well as to preach whenever an opening presented itself, to adult idolaters. Our plan is now so extended as to admit of a division of labour."

We have seen how young M'Cheyne and Somerville were moved by the interview which they sought with the returned missionary. Duff never lost his hold on M'Cheyne, who soon after formed one of the Church's mission of inquiry into the condition of the Jews in Palestine and Eastern Europe. In April, 1836, the saintly young preacher wrote in his journal:- " Went to Stirling to hear Dr. Duff once more upon his system. With greater warmth and energy than ever. He kindles as he goes. Felt almost constrained to go the whole length of his system with him. If it were only to raise up an audience it would be defensible, but when it is to raise up teachers it is more than defensible. I am now made willing, if God shall open the way, to go to India. 'Here am I; send me!" His biographer, Dr. A. Bonar, remarks that " the missionary feeling in M'Cheyne's soul continued 
all his life. Must there not be somewhat of this missionary tendency in all true ministers?" Yet the only one of the M'Cheyne band who practically answered this question, besides William Burns, of China, was John Milne, of Perth, who was afterwards for a fer years Free Church minister in Calcutta. Macdonald's resignation of a home charge for a missionary's apostolate caused so much excitement as to irritate him into putting the question to the degenerate Church-" Why is not such an event commonplace?"

Edinburgh and St. Andrews had sent their best students to the field; it was now the turn of Glasgow, which had been doing much for Kaffraria, to inquire. The ripest scholar in its university proved to be the most devoted student of theology. James Halley, A.B., was the favourite disciple of Sir Daniel K. Sandford, who, having imbued him with the very spirit of a reverent Hellenism, introduced him to the Edinburgh Professor of Greek as "the man who beat Tait," the present Archbishop of Canterbury. He promised to be the ornament of his university and of the Church, when death prematurely closed his bright career. What he was, the Rev. Williain Arnot's little memoir tells us. He hurried through from Glasgow, with James Hamilton, afterwards of Regent Square, to hear Duff's speech in the Assembly of 1835, and arrived only in time to witness its effect. He describes it as " a noble burst of enthusiastic appeal which made gres-headed pastors weep like children, and dissolved half the Assembly in tears." The immediate effect on him was seen in the College Missionary Society, of which he was president. Addressing Dr. Macfarlan, the principal of the University, and Dr. Duff afterwards, Mr. Halley sought their encouragement of the students' missionary aims. The former replied, declining to contribute even the usual 
guinea, warning them that "such exertions on the part of the students are premature and injudicious," and thus concluding: "I trust you will receive this explanation as a proof at once of my deep interest in the real welfare and improvement of the students attending this university, and of the personal regard for yourself." We are not parodying the words, nor misrepresenting the acts of the head of the University of Glasgow in the year 1835. Early in $1837 \mathrm{Mr}$. Halley received from Dr. Duff this reply :-

\section{“ Pitlochrie, 7th March, 1837.}

"I had once expected to have been able to meet your association in person, in which case much could be advanced that cannot well be committed to writing. But it was a constitution shattered beyond hope of recovery in a tropical clime that drove me from the field of labour ; and ever since my arrival in my native land I have been buffeting with the dregs of tropical disease. In this way, rocked by discipline and cradled by disappointment, I have been unable to overtake a tithe of what I had originally proposed to myself. But as it is the ordination of Heaven, I trust I have learned to submit in patient resignation, ever ready to adopt the language of my Saviour and Redeemer'Even so, Father, for so it seemed good in Thy sight.'

"In the midst of the thunder of clashing interests and the lightning of angry controversy in this distracted land, how sweet, how refreshing to the soul to enter the quiet haven of devotion, and there hold communion with the great I Am, and the Lamb slain from the foundation of the world, and the Holy Spirit that enkindles with the fervour of divine love. It is this feature in the organization of your societyeffective as it is in other respects also-that inspires me with the purest joy. An alternate meeting is 
devoted, you say, to Christian fellowship, prayer and the reading of missionary intelligence. God be praised who has put it into your hearts to unite in such hallowing exercises. If such meetings were more general they would be the rallying centres of hope to a divided Church and a bleeding world.

"You advert to the chilling influence of academic pursuits on the growth of piety in the soul. Most keenly have I felt it myself. How is it to be obviated? By constantly falling back on the touching and searching simplicity of God's own word, and constantly besieging a throne of grace with the honest effusions of a heart panting and thirsting after the love of God. Without the unceasing recurrence of such soul-reviving exercises I have learned, from sad experience too, that even religious pursuitswhether these consist in replenishing the intellect with divine knowledge or in the multiplied duties of the ministerial office-that even such pursuits may drain up the fountain-head of spiritual vitality and cause the plant of renown in the soul, for a season at least, to droop and wither and decay.

"You complain of indifference to religion in general and missions in particular. $\mathrm{Oh}$, it is this indifference which I fear may eventually prove the ruin of our land, if God in mercy do not send some trumpet-peal to rouse us from our lethargy! The work of missions is so peculiarly a Christian work that neither its principles nor its objects can be rendered perfectly intelligible to any but God's own children. Indifference to religion in general must, therefore, produce indifference to the missionary cause. These are related as an antecedent and consequent, as cause and effect. If the souls of men have not yet been awakened to a sense of sin and danger-if they have not yet been sanctified, they cannot be susceptible of 
any spiritual impression from any quarter whatever. - To arrest the attention of such persons in a vital manner, and secure their sympathies and their exertions in behalf of the perishing heathen, we must first arouse them to a lively personal concern for the salvation of their own souls."

Another who was then a youth of promise, and became the founder of the Edinburgh Medical Missionary Society, if not of Medical Missions, was profoundly impressed. We find Dr. Coldstream, who had just settled in Leith as a physician, thus writing in 1837: "The missionary sermon and lesson of yesterday, by Dr. Duff, were most impressive. I have no words to express their thrilling effect. - . I think I never felt so strongly the delig': :ful influence of the bond of Christian love. The very spirit of love seemed to move with electric fire through the great assembly, knitting heart to heart, and kindling sparks of holy zeal. It is a day much to be remembered." When, thirteen years afterwards, Dr. Duff publicly referred to a series of lectures on Medical Missions published by that most successful society, and asked " when will some of these lecturers set the example of devoting themselves to the missionary service and come out to India?" as has since been done, Dr. Coldstream replied, "I feel as if you had put the question to me individually."

The report of the speech of 1835 found its way to the retreat, near Dumfries, of a young licentiate of the. Kirk whom sickness had laid aside. John Anderson had passed through the eight years' studies of the University of Edinburgh the first man of his set. Like Jolin Wilson at an earlier time, he had come under the influence of Dr. Gordon, who to his labours in pulpit and parish added the duties of secretary of the Foreign Missions Committee. Having refused the office of 
assistant to a minister, John Anderson was altogether despairing of health, and was already thirty-two, when that happened which he himself shall describe-“ We well remember the time when, on his return from India, the Rev. Dr. Duff, emaciated by disease and worn out with the strenuous exertions of the first five years of his missionary life, delivered his first speech on India Missions. - . Its statements flew like lightning through the length and breadth of Scotland, vibrated through and warmed many hearts hitherto cold to missions, and tended to produce unity among brethren standing aloof from each other. Never will we forget the day when a few of its living fragments caught our eye in a newspaper in our quiet retreat on the banks of the Nith, near Dumfries, when suffering from great bodily weakness. It kindled a spirit within us that raised us up from our bed, and pointed as if with the finger to India as the fold of our future labours." Already had Anderson, as a tutor, been able to train men like John Cowan, Esq., of Beeslack. But his indomitable will and untiring energy were now called to found and build up in Madras the General Assembly's Institution, which has since expanded into the great catholic Christian College of Southern Indiathe first to realize Dr. Duff's ideal of a united college representing all the evangelical churches. Ordained in St. George's, Edinburgh, by Dr. Gordon, Mr. Anderson visited the Calcutta Mission before setting up his own on its model, and was soon after joined by such colleagues, also the fruit of Dufr's appeals, as Messrs. Johnston and Braidwood from the same university. Aberdeen at the same time joined her sister colleges in the high enterprise, by sending Dr. Murray Mitchell to Bombay. The harvest, for that season, was finished by another missionary from Edinburgh, the Rev. Thomas Smith, to whose ordination we shall again 
refer. The opening of the Central India Mission in Nagpore, a few years after, by Stephen Hislop, completed the Indian organization of the missions of the Church of Scotland, established and free. All, directly or indirectly, are to be traced to the living seed sown amid so much weakness but yet with such power in $1835-36$.

After a rest at Edradour, all too short, Dr. Duff went up to London at the beginning of May, 183\%, to take part in the anniversary of the Church of Scotland's Foreign Missions, held by the London Pres. bytery in Exeter Hall. After much searching we have been able to discover in an old volume of pamphlets of the period a copy of what his English critics have always pronounced by far the most eloquent of Dr. Duff's speeches. Though weak, he was no longer the fever-wasted man who had excited the alarm of the Assembly of 1835. By unrivalled experience in both England and Scotland he had learned the defects of the home Churches and of the best stay-at-home Christians in relation to the missionary command of Christ. And so, as he mused on the contrast between the profession and the reality, as he listened to the rhetorical periods of bishops and clergymen, of ministers and professors who talked but did nothing more, the fire of indignation burned forth into glowing sarcasm. Nothing short of a reprint of the twenty-five pages of that rare address could do justice to this vein of the impassioned orator. Severed from the context, without the flashing eye, the quivering voice, the rapid gesticulation, the overwhelming climax, the few passages we may now reproduce seem cold and formal indeed. But we must premise the orator's own explanation of the satire-“"These expressions are in allusion to certain tropes and figures that have actually flourished amid the exuberant rhetoric of Exeter Hall." 
Beginning, in the highest style of his art, as Demosthenes and Cicero and Paul before Agrippa had done, this modern prophet, sent from the millions of Hindooism to the very centre of Christian profession, congratulated London, and especially its Scottish residents, on the reception of the appeal lately sounded in their ears " in behalf of our suffering countrymen in the Highlands and islands of Scotland. Nobly and righteously, and in a way worthy of the wealthiest metropolis in the world, has the appeal been responded to. But why is it that we should be affected even unto horror at the melancholy recital of mere temporal destitution, while we are apt to remain so cold, callous and indifferent to the call of spiritual necessities that is rung in our ears, loud as the cry of perishing multitudes which no man can number?" Then after skilfully picturing the horrors of famine and pestilence among our own countrymen and within the narrow limits of our island, and asking if imagination could conceive aught more harrowing, he replied: "No! not to the natural feeling, even although such a death is by the hands of a mysterious Providence. To the higher order of spiritual sensibility, however, something may be presented more harrowing still. I know a land where earth, sea and air conspire in favour of its inhabitants-a land so gorgeously clad that it has been emphatically styled 'the climes of the sun.' And truly they are ' the climes of the sun ;' for there he seems to smile with exuberant bounty, and causes all nature to luxuriate in her rich magnificence. There the glowing imagery of the prophet seems almost literally to be realized. The trees of the forest seem to clap their hands, and the valleys seem to rejoice on every side. All bespeak the glories of a presiding Deity and recall to remembrance the bowers of Paradise. But oh! in this highly favoured land- 
need I say I refer to India?-which for beauty might be the garden of the whole earth, and for plenteousness the granary of the nations, - in this highly favoured land children are doomed to see their parents and parent's their children perish-perish, not becauso there is no meat in the field, no flocks in the fold, no cattle in the stall, but because they are goaded on by the stimulants of a diabolical superstition to perish miserably by each other's hands."

Then followed word-pictures of that which may still be seen along the Hooghly- "sons and daughters piously consigning a sickly parent, for the benefit of his soul, to the depths of a watery grave;" of "the putrid corpse of the father and the living body of the mother" burning together, in every feudatory state at that time, and only in 1828 prohibited in the East India Company's territory ; of the sacrifice of children by their mothers to the waters of Gunga and the jaws of the alligator; and of the systematic murder of female infants by the Rajpoot castes from Benares to Baroda. Rising from one scene of pitiful horror to another, every one of which an audience even of 1837 knew to be living fact and not old history as we now happily do, thanks to Missions and Christian appeals, the rapt speaker reached the highest of all in the spiritual destitution and debasement which had made such crimes inevitable; and in the means which he had taken, through sacred and secular truth harmoniously united, to give India a new future. A farseeing demand for pure English and vernacular literature, beginning with " the Bible, the whole Bible, the unmutilated Bible, and nothing but the Bible," for those whom both state and church were educating, brought Dr. Duff to the practical object of his address - the duty of every Christian man, woman and child in Great Britain. 
"Look at men's acts and not at their words, for I am wearied and disgusted with very loathing at 'great swelling words' that boil and bubble into foam and froth on the bosom of an impetuous torrent of oratory and then burst into airy nothingness. Look at men's acts, and tell me what language do they speak? Is it in very deed a thing so mighty for one of your nobles or merchant princes to rise up on this platform aud proclaim his intense anxiety that contributions should be liberal, and then stimulate those around him by the noble, or rather ignoble, example of embodying his irrepressible anxiety in the magnificent donation of $£ 10, £ 20$, or $£ 50$ ! when, at the very moment, without curtailing any of the real necessaries of life, without even abridging any one of its fictitious comforts or lnxuries, he might readily consecrate his hundreds or thousands to be restored more than a hundred-fold on the great day of final recompense? And call you this an act of such prodigious munificence that it must elicit the shouts and the pæans of an entranced multitude? Call you this an act of such thrilliug disinterestedness that it must pierce into hearts otherwise hermetically sealed against the imploring cries of suffering hurnanity? Call you this an act of such self-sacrificing generosity that it must be registered for a memorial in the book of God's remembrance, with the same stamp of Divine approbation as that bestowed on the poor widow in the gospel, who, though she gave but little, gave her all?

"And is it in very deed a thing so mighty for a Christian pastor, whether bishop, priest or deacon, or any member of 8 Church, to abandon for a season his routine of duty, and once in the year to come up, either to regale, or be regaled, with the incense of human applause in this great metropolis, the emporium of the world's commerce, the seat of the world's mightiest empire, and the general rendezvous of men and things unparalleled in all the rorld besides? Is it a thing so mighty for any one of these to stand up on this platform, and call on assembled thousands to rise to their true elevation, and acquit themselves like men in the cause of Him who rides on the whirlwind and directs the storm? And, dismissing all ordinary forms and figures of speech as tame and inadequate, is it an act so heroic to stand on this platform, and break forth into apostrophes, that ring with the din of arms and the shout of battle? Is it an act so heroic, at the safe distance of ten 
thousand miles, courageously to summon the gates of Peking to lift up their heads, and its barricades and ramparts to rend asunder at the presence of the heralds of salvation? and, impersonifying the celestial empire herself, boldly invoke her to send up without delay her hundreds of millions to the house of the Lord, exalted above the hills, and place her imperial crown on the head of Him on Whose head shall be all the crowns of the earth, and the diadem of the universe?

"Or, is it an act of spiritual prowess so mighty, for one who never joined in the conflict, to stand up on this platform, and rehearse the battles that have been fought in the missionary field, the victories that have been obtained, and the tropbies that have been won? Is it an achievement of never-dying fame to burst into rapture at the unrivalled honour of those brave veterans that have already laid down their lives in storming the citadels of heathenism? Hark! here are a few blasts from a trumpet that has often pealed, and pealed with effect, at our great anniversaries. The missionary's life? Ah ! 'an archangel would come down from the throne, if he might, and feel himself honoured to give up the felicities of heaven for a season for the toils of a missionary's life.' The missionary's work? Ah! 'the work of a minister at home, as compared with that of a missionary, is but the lighting of a parish lamp, to the causing the sun to rise upon an empire that is yet in darkness.' The missionary's grave ? Ah ! 'the missionary's grave is far more honourable than the minister's pulpit.'

"After such outpourings of fervent zeal and burning admiration of valour, would ye not expect that the limits of a kingdom were too circumscribed for the range of spirits so chivalrous? Would ye not expect that intervening oceans and continents could oppose no barrier to their resistless career? Would ye not expect that, as chieftains at the head of a noble army, numerous as the phalanxes that erewhile flew from tilt and tournament to glitter in the sunshine of the Holy Land, they should no more be heard of till they make known their presence, by the terror of their power, in shattering to atoms the towering walls of China, and hoisting in triumph the banners of the Cross over the captured mosques of Araby and prostrate pagodas of India? Alas, alas! what shall we say, when the thunder of heroism that reverberates so sublimely over our heads from year to year in Exeter Hall, is found, in 
changeless succession, to die away in fainter and yet fainter echoes among the luxurious mansions, the snug dwellings, and goodly parsonages of Old England!

"Listen to the high-sounding words of the mightiest of our anniversary thunderers on this platform, and would ye not vow that they were heroes, with whom the post of honour was the post of danger? Look at the astounding contrast of their practice, and will not your cheeks redden with the crimson flush of shame, to find that they are cowards, with whom the post of honour is, after all, the post of safety? Ye venerated fathers and brethren in the ministry, whom I now see around me, of every denomination-to you I appeal. I appeal in the spirit of faithfulness, and yet in the spirit of love, and ask :Is this the way to awake the long-slumbering spirit of devotedness thronghout the land? Is this the kind of call that will arouse the dormant energies of a sluggish Church? Is this the kind of summons that will cause a rush of champions into the field of danger and of death? Is this the kind of example that will stimulate a thousand Gutzlaffs to brave the horrors of a barbarous shore? - that will incite thousands of Martyns, and of Careys, and of Morrisons, to arm themselves on the consecrated spots where these foremost warriors fell? I know not what the sentiments of this great audience may be on a subject so momentous ; but as for myself, I cannot, at whatever. risk of offence to friends, and of ribaldry from enemies,-I cannot, without treason to my God and Saviour,-I cannot but give vent to the overpowering emotions of my own heart, when, in the face of England, Scotland and Ireland I exclaim, ' $\mathrm{Oh}$ that my head were waters, that mine eyes were a fountain of tears, that I could weep over the fatal, the disastrous inconsistencies of many of the most renowned of the leaders of our people!'

"What, then, is to be done? How are the gigantic evils complained of to be efficiently remedied? Never, never, till the leading members of our Churches be shamed out of their lavish extravagance in conforming to the fashion of a world that is so soon to pass away, and out of their close-fisted penurionsness as regards all claims that concern the eternal destinies of their fellows. Never, never, till the angels of our Churches, whether ordinary pastors or superintending bishops, be shamed out of their sloth, their treachery and their cowardice. For, 
rest assured, that people would get weary of the sound of the demand 'Give, give,' that is eternally reiterated in their ears, when those who make it so seldom give, or, what is the same thing, give in such scanty driblets that it seems a mockery of their own expostulations, - and of the sound of the command 'Go, go,' when those who make it, are themselves so seldom found willing to go !

"How, then, is the remedy to be effected? Not, believe me, by periodical showers of words, however copious, which fall 'like snow-flakes in the river, $-\mathbf{a}$ moment white, then gone for ever.' No ; but by thousands of deeds that shall cause the very scoffer to wonder, even if he should wonder and perish-deeds that shall enkindle into a blaze the suouldering embers of Christian love-deeds that shall revive the days of primitive devotedness, when men, valiant for the truth, despised earthly riches, and conquered through sufferings, not counting their lives dear unto the death."

"Archangels," he said, "cannot leave their thrones; but where are the learned and the eloquent, the statesmen and the nobles,-where is one of our loudtalking professors ready to do more than shrivel their little services into the wretched inanity of an occasional sermon, or a speech, easily pronounced and calling for no sacrifice? . . What! expect one and all of these to descend from their eminences of honour and go forth themselves content with the humble fare and arrayed in the humble attire of self-denying missionaries? Is not this the very climax of religious raving? Gracious God! and is it really so ? . Are we in sober seriousness determined to contract the calculus of eternity within the narrow dimensions of the arithmetic of time? Do I now stand in an assembly of professing Christians ?" Then the sacred orator, turning from sarcasm and irony, from reproach and prophetic ridicule, thus closed with his entranced audience in the presence of Him who gave Himself :-

"With deep solemnity of feeling let me ask:-Who is 
this that cometh from Edom, with dyed garments from Bozrah ?' It is the Man who is Jehovah's fellow. It is Immanuel, God with ns. But who can portray the underived, the incomparable excellencies of $\mathrm{Him}$, in whom dwelt all the fulness of the Godhead bodily? In this contemplation we are at once lost in an immeasurable ocean of overpowering glory. Imagination is bewildered; language fails. Go take a survey of the earth we dwell npon. Collect every object and every quality that has been pronounced fair, sweet, or lovely. Combine these into one resplendent orb of beauty. Then leave the bounds of earth. Wing your flight through the fields of immensity. In your progress collect what is fair and lovely in every world, what is bright and dazzling in every sun. Combine these into other orbs of surpassing brightness, and thus continue to swell the number of magnificent aggregates, till the whole immense extent of creation is exhausted. And after having united these myriads of bright orbs into one glorious constellation, combining in itself the concentrated beanty and loveliness of the whole created universe, go and compare an atom to a world, a drop to the ocean, the twinkling of a taper to the full blaze of the noon-tide sun;-then may you compare even this all-comprehending constellation of beauty and loveliness with the boundless, the ineffable beauty and excellence of Him who is 'the brightness of the Father's glory,' who is 'God over all, blessed for ever!'

"And yet wonder, $O$ heavens, and rejoice, $O$ earth; this great, and mighty, and glorious Being did for our sakes condescend to veil His glory, and appear on earth as a Man of sorrows, whose visage was so marred more than any man's, and His form more than the sons of men. $\mathrm{Oh}$, is not this love!-self-sacrificing love!-love that is 'higher than the heights above, deeper than the depths beneath'? Oh, is not this condescension!-self-sacrificing condescension!-condescension without a parallel and without a name? God manifest in the flesh! God manifest in the flesh for the redemption of a rebel racel $\mathrm{Oh}$, is not this the wonder of a world? Is not this the astonishment of a universe?

"And, in the view of love so ineffable and condescension so unfathomable, tell me, oh tell me, if it would seem aught so strange-I will not say in the eye of poor, dim, beclouded bumanity-but in the eje of that celestial hierarchy that 
caused heaven's arches to ring with anthems of adoring wonder when they beheld the brightness of the Father's glory go forth eclipsed, mysteriously to sojourn on earth and tread the winepress alone, red in His apparel and His garments dyed in blood? Tell me, oh, tell $\mathrm{me}$, if in their cloudless vision it would seem aught so marvellous, so passing strange, did they behold the greatest and the mightiest of a guilty race, redeemed themselves at so vast a price, cheerfully prepared to relinquish their highest honours and fairest possessions, their loveliest academic bowers and stateliest palaces; yea, did they behold Royalty itself retire and cast aside its robes of purple, its sceptre and its diadem, and issue forth in the footsteps of the Divine Redeemer into the waste howling wilderness of sin, to seek and to save them that are lost?

"Ye grovelling sons of earth, call this fanaticism if yon will; brand it as wild enthusiasm;-I care not for the verdict. From you I appeal to the glorious sons of light, and ask, Was not this, in principle, the very enthusiasm of patriarchs, who rejoiced to see the day of Christ afar off, and were glad? Was not this the enthusiasm of prophets, whose harps, inspired by the mighty theme, were raised into strains of more than earthly grandeur? Was not this the enthusiasm of angels that made the plains of Bethlehem ring with the jubilee of peace on earth and goodwill to the children of men? Was not this the enthusiasm (with reverence be it spoken) of the eternal Son of God Himself, when $\mathrm{He}$ came forth travailing in the greatness of $\mathrm{His}$ strength, to endure the agony and bloody sweat? And if this be enthusiasm that is kindled by no earthly fire, and which, when once kindled, burns without being consumed, how must the hopes of the Church lie sleeping in the tomb, where it does not exist? Oh! until a larger measure of this divine enthusiasm be diffused through the Churches of Christendom, never, never need we expect to realize the reign of millennial glory-when all nature shall once more be seen glowing in the first bloom of Eden; when one bond shall unite and one feeling animate all nations; when all kindreds and tribes and tongues and people shall combine in one song, one universal shout of grateful 'Hallelujah unto Him that sitteth upon the throne, and to the Lamb for ever and ever!'"' 
We have not met with a record of the effect of this denunciation and appeal, any more than with a report of that which Dr. Duff had uttered in the same hall in the previous year at the anniversary of the Church Missionary Society. But we know that the Rev. John Macdonald had given himself to the mission as the result of Dr. Duff's earliest visit of all, in 1835 ; and money at least was not stinted, for it was announced to the Assembly held a few weeks after that $£ 700$ had been sent as the result of that meeting.

The General Assembly of 1837 is memorable in ecclesiastical annals for the happily rare event of a contest regarding the moderatorship. It is of interest here because of Dr. Duff's "Vindication of the Church of Scotland's India Missions," in reply to the misunderstandings and misrepresentations which had arisen out of his speech of 1835 , to which, as an oratorical effort, it comes only second. The local reporters wrote: "This eloquent address produced, amidst the profound silence with which it was listened to, occasional bursts of enthusiasm which were irrepressible; and the peroration at its close called forth an expression of emotion in the Assembly such as we have rarely witnessed." The Assembly ordered its publication. Led by Dr. Muir, of Glasgow, in united prayer the members returned thanks to God for preserving the health and life of their dear brother, Dr. Duff. The "Vindication" has a value which is more than historical, from the demand that the Church should send out its most highly educated ministers and ablest preachers as missionaries to races like the Hindoos, and from this still necessary answer to the Ignorant and the malevolent:-

"Let it never be forgotten that, as the Government schemes of education uniformly exclude religious instruction, this may only be a change from a stagnant superstition to a rampant 
infidelity. What then is to be done? Are the Christians of Great Britain to stand idly aloof and view the onward march of the spirit of innovation in the East as unconcerned and indifferent spectators? Forbid it, gracious Heaven! What then is to be done? Why, if we are faithful to our trust, and wise in time, we may, through the blessing of God, be honoured in converting the education plans of the Indian Government into auxiliaries, that may lend their aid in preparing the way for the spread of the everlasting gospel! Wherever a Government seminary is founded, which shall have the effect of demolishing idolatry and superstition, and thereby clearing away a huge mass of rubbish; there let us be prepared to plant a Christian institution, that shall, through the blessing of Heaven, be the instrument of rearing the beanteous superstructure of Christianity on the ruins of all false philosophy and false religion. Wherever a Government library is established, that shall have the effect of creating an insatiable thirst for knowledge; there let us be forward in establishing our depositories of Bibles and other religious publications, that may saturate the expanding minds of Indian youth with the life-giving principles of eternal truth. And who can tell whether, in this way, by ' redeeming the time'by seizing the present golden opportunity-we may not be privileged to behold all the Government schemes of educational improvement in India overruled by a gracious superintending Providence for the ultimate introduction of Messiah's reign?

"From having formerly said so much on the power of useful knowledge in destroying the systems of Hindooism, it has been strangely concluded by some that our object has been to reform the natives of India by means of 'knowledge without religion.' Need I say that no conclusion could possibly be more unfounded? It is, indeed, most true that, for reasons which have more than satisfied many of the wisest and most devoted Christians in this land, I have, with uniform and persevering earnestness, advocated the universal diffusion of sound knowledge in India. Not contented with seeing such kuowledge ooze out in scanty drippings, I have toiled and laboured, in conjunction with others, to pour it out in copious streams that may, one day, cover the whole land with the swelling tide of reason and intelligence. This, however, 
happens to be only one-half of any statement that I have ever, anywhere, made on the subject. And what right has any one, in reason or in justice, to fasten on one-half of a statement, and deal with that half as if it were the whole? Strongly and sincerely as I have pled for the diffusion of sound general knowledge in India, have I not, on every occasion, insisted as strongly on the contemporaneous diffusion of religious truth ? Have I not even laboured to demonstrate that, for the best interests of man in time and eternity, the former should ever be based on the latter-pervaded with the spirit of it throughout and made to terminate in its exaltation and supremacy? Have I not ever contended for the holy and inseparable alliance of both?-for the reciprocal inter-blending of their different, though not uncongenial, influences? And if one or other must have the precedency, either as respects priority of time or dignity of position, in the mighty work of regenerating a corrupt world; in the name of all that is reverend and just, let that be selected for the honour which, by inherent superiority and excellence of nature, is preeminently entitled to it.

“ Without 'useful knowledge' man might not live so comfortably in time: without 'divine knowledge' eternity must be lost. How then could the missionaries of the Church of Scotland-the missionaries of a Church first loosened from Popery by the Wisharts and Hamiltons, subsequently established by the Knoxes and Melvilles, and onwards perpetuated by the Rutherfords and Halyburtons-how could we dare to sacrifice, at the shrine of a spurious liberality, that highest and sublimest knowledge, whose ennobling truths many of these worthies so heroically died to testify? Or, if we dared thus to act the part of degenerate children, how could we abide the piercing glance of rebuke which they would cast upon us, if recalled from the realms of day to witness our treacherous cowardice? And how might we not feel, even now, as if their very ashes would speak out of the tomb, and their blood from under the altar cry out against us! Such, indeed, and so strong, are my own convictions of the vast importance of nseful knowledge in the great work of reforming India, that were this venerable house to forbid the diffusion of it in connection with its own mission, I, for one, would feel myself, however reluctantly, constrained at once to relinquish the 
honourable position which it has been pleased to assign to me. But such, and so overwhelming, are my convictions of the immeasurably superior importance of that higher knowledge, which nrseals the fountain of Immanuel's love, that-sooner than consent wilfully to withhold it for an hour from the famishing millions of India, or of any other land, in deference to the noxious theories of certain propagandists of the present day-I would lay down my head upon the block, or commit this body to the flames!

"I feel assured, however, that, so far as this house is concerned, it will never fall iuto either of these extremes. Notwithstanding the charges of religious bigotry that have been so profusely heaped upon it, this house, like its noble reforming ancestry, has been, is now, and, I trust, ever will be, the consistent, the enlightened advocate of all really useful knowledge throughout the wide domain of families, schools and colleges, whether in this or in other lands. And, notwithstanding the charges of secular convergency that have been as abundantly levelled at it, this house, like its noble reforming ancestry, has been, is now, and, I trust, ever will be, the intrepid, the unbending advocate of a thorough Bible instruction, as an essential ingredient in all sound education, whether on the banks of the Forth or on the banks of the Ganges. Yea, may I not be permitted with emphasis to add, that, sooner than consent to surrender this vital principle, which is one of the main pillars in the palladium of the Protestantism of these realms, this house is prepared, as in times of old, to submit to dissolution by the strong arm of violence?-and its members, like their fathers of the Covenant, prepared once more to betake themselves to the dens and caves of the earth - to wander by the lonely shore or over the desert heath, to climb the mountain-steep for refuge, or secretly assemble to worship in 'some deep dell by rocks o'ercanopied'?

"Let it, then, ever be our distinguishing glory to arbitrate between the advocates of untenable extremes. Let us, on the one hand, disown the bigotry of an unwise pietism, by resolving to patronise to the utmost, as in times past, the cause of sound literature and science-lest, by our negligence, in this respect we help to revive the fatal dogma of the dark ages, that what is philosophically true may yet be allowed to be theologically false. And let us, on the other hand, do- 
nounce the bigotry of infidelity, or religious indifference, by resolving to uphold the paramount importance of the sacred oracles, in the great work of christianizing and civilizing a guilty world. Let us thus hail true literature and true science as our very best auxiliaries-whether in Scotland, or in India, or in any other quarter of the habitable globe. But, in receiving these as friendly allies into our sacred territory, let us resolutely determine that they shall never, never, be allowed to usurp the throne, and wield a tyrant's sceptre over it."

The foresight and the faith, the culture and the self-sacrifice of that passage, reveal the height and the breadth of the speaker's Christian statesmanship. Every year since he spoke it has only given new force to its truth, new reason for regret that the Church and the Government alike were not wise in time to seize the golden opportunity. Even Lord William Bentinck's Government had refused the Mission College a grant-in-aid in recognition of the secular instruction it gave, lest the Company, which was a partner with the priests of Jugganath in their gains from the deluded pilgrims, and which ordered its Christian officers and Muhammadan sepoys to salute the elephant-headed, pot-bellied idol Gunputty, should hurt the religious feelings of the natives. The Mutiny came, and brought the catholic universities with it. The Mutiny passed-but at what a price? In vain, to this hour, by gagging the press and imprisoning libellous or treasonable editors, does the Government try to undo the evil effects of the undiluted and rigid secularism of its schools and colleges. It goes on sowing the wind as no other Government on earth does or in history has ever done. Woe to India and to the Church-to the three Churches of Scotland especially which, in Duff and Wilson, and now in Dr. Shoolbred, have been honoured to lead the way-if this warning is forgotten! 
Dr. Duff went further. The spiritual reformation of the varied peoples of India he saw must be effected by themselves when foreigners had thus handed on the divine torch to "the Luthers and the Calvins and the Knoxes of Hindostan":-

"Our object, therefore, is not local or partial, individual or temporary. It is vast and all-comprehensive. It is nothing less than intellectually and spiritually to reform the universal mind of India; and not merely so, but to embody the essential spirit of the reformation in improved institutions, that shall perpetuate its blessings to latest ages. But, has it ever been heard of, that a great and permanent reformation, in any land, has been the work of a day, or a year, or even a single age? Never, never. A great reformation is not merely the pregnant cause of innumerable happy effects:-it is itself but the aggregate effect of innumerable predisposing causes, that may have been accumulating for centuries, ere they became ripe for explosion. Viewed in this respect, the Reformation of Luther has been well compared to the rapids of a river, in its precipitous passage from some mountain range to the level plains below. Now, for India we not only contemplate a religious reformation, as effective as that of Luther in Europe, but a reformation still more pervasive, and more thoroughly national.

"As yet, however, we are only defiling among the wild, upland, and mountain ranges of Hindooism, with its bleak wastes of fable, its arid knolls of prejudice, its frowning crags of superstition, its towering eminences of idolatry. But already, blessed be God, after the long dark night of forty centuries, has the Sun of righteousness begun to gild the Eastern horizon. Already are His earliest beams seen reflected from the frozen summits. Already are there droppings of truth on many a rocky heart. Already are there under-currents of inquiry, that shall one day emerge from the hidden recesses of individual minds. Already are there evangelical founts that send forth their little rills of saving knowledge. Already are the clouds fast gathering, surcharged with the waters of salvation, and ready to pour down their copious showers. And soon may the swollen brooks uuite 
into rivers, and rivers into a mighty stream of quickening influences. For some years more, the mighty stream itself may continue to flow on through comparatively barren and unanimated solitudes. At length, impatient of restraint, it must burst its accustomed boundaries, and, dashing headlong, in the foam and thunder of a cataract of reformation, it will gently glide into the peaceful under-vale of time. There it shull roll on in its majestic course, overspreading its banks with the verdure of righteousness, and pouring the fertility of paradise into its pastures of gospel grace, till it finally disappear and is lost in the shoreless ocean of eternity!

"Persuaded, as I feel, that such is our present position among the incipient processes that shall, in due time, unite and issue in so glorious a consummation, I, for one, am cheerfully willing to toil on, for years, in feeding, if it be but one of the little rills of awakening influence,-though I should never live to behold their confluence into the mighty stream of sequences, with its rushing cataract, and waviug harrest gladdening its after-course. And, as regards the ultinate realization of the magnificent prospect, I would, even on a dying pillow, from a whole generation of doubters confidently appeal to posterity."

We have seen how of his first four converts three had become teachers, and were soon to become preachers of the gospel, but under the Church of England, the London and the American Missionary Societies, because the Church of Scotland was not prepared to send forth the young evangelists in her own name. Dr. Bryce, who had retired from the ecclesiastical service in Bengal, rose in the General Assembly " after the heart-stirring and transcendently eloquent speech" of Dr. Duff, to tell its members how something at least was to be done to remedy this for the future. The Assembly of 1834 had created three presbyterial bodies at Calcutta, Bombay and Madras, which united in sending representatives to the central and highest court. These bodies drew up a course of study to be followed by converts who sought to be 
licensed preachers and ultimately ordained missionaries to their countrymen. In attempting to fix this course, said Dr. Bryce, "the presbytery felt that a very great latitude must be held as allowed to them, alone acquainted as they could be with local circumstances. But of this latitude they felt disinclined to avail themselves beyond the necessity of the case, and after the most mature deliberation given to the subject, they determined to follow generally as a model, and as far as practicable, the course pursued at our Divinity halls at home." We do not know how far this decision would have been modified had Dr. Duff been in Calcutta, although his letter at page 281 seems to imply that he would have followed the Scottish model less slavishly. While we admire the determination to secure a learned as well as godly native ministry, shown in the rule which compels Bengalee, Marathee, Goojaratee, Tamul, and even simple Sonthalee converts to pass a satisfactory examination in Hebrew, Greek and Latin, and to sign the historical documents of the Scottish Churches before being licensed to preach, we are compelled by hard facts as well as common sense to ask if it is thus we shall raise or equip native Luthers. Is it a Christian Nanuk or a Hindoo Calvin that India needs? As the story of the mission goes on we shall meet with able Bengalee converts, made preachers and missionaries because they have satisfied the presbytery according to Dr. Bryce's still enforced "course of study." But financially as well as ecclesiastically and even spiritually, this parody of Western theological training has worked so badly that the three Scottish Churches have been asked by their missionaries to sanction an evangelical course and creed more like those of the Apostles and the Church at Antioch, and not less thorough and pure than those of covenanting, 
much-suffering, often testifying and still sorely divided Scotland. The Church of India has grown so far out of infancy that it asks to be freed from the controversial swaddling-bands of the West.

After again visiting some of the presbyteries in the south of Scotland, Dr. Duff began his preparations for returning to India. But he was premature. His general health was suffering so greatly that he was detained, and was even forbidden to attend the Assem. bly of 1838 , by his medical adviser, Dr. Macwhirter, who had been for years physician to the Countess of Loudoun, wife of the Marquis of Hastings, GovernorGeneral of India. Dr. Macwhirter when in Calcutta had the reputation of being an exceedingly skilful physician, while he was one of the most gentle and amiable of men. After full personal inspection and all manner of inquiries, the physician lifted up his hands in astonishment, expressing the utmost surprise that, with a body so weakened by general as well as special disease, and so exhausted by the prodigious labours undergone, Dr. Duff had been able to persevere, though at the same time he had done so, unconsciously to himself, not only at the risk of permanent injury but of premature death. "You are not at all in a fit state to return to India," said Dr. Macwhirter. "You must have months of perfect quiet under proper medical treatment with a view to recruiting. If you can really submit to this, since you are still but young in years and evidently have a singularly wiry and iron constitution, my medical judgment is that, after a reasonable time you will be so far recruited as to warrant you to return. My earnest advice to you, therefore, is at once to return to your quiet Highland home, where by correspondence I can perfectly regulate, from day to day if need be, your regimen and medical treatment; there you 
will have the tender, nursing care of the members of your own family about you." Thus most of the autumn, and a considerable part of the winter of 1838-39, was spent at Edradour.

In that quiet and beautiful retreat Dr. Duff only exchanged the roice for the pen. From all parts of the kingdom and from other lands he was applied to for counsel or information or help on the most catholic grounds. Among others whom his earliest addresses had roused were " a few friends of the missionary enterprise in Scotland,"* as they described themselves, who offered two prizes, of two hundred and fifty guineas in all, for the best essays on "The Duty, Privilege, and Encouragement of Christians to send the Gospel of Salvation to the Unenlightened Nations of the Earth." Dr. Duff, with whom Dr. Chalmers and Professor M'Gill, of Glasgow, were associated as promoters of the philanthropic enterprise, conducted a remarkable correspondence on the subject, declaring that if he had the means he would himself supply the money. This is the first illustration in Scotland of what we have seen in Bengal-his conviction that for foreign missions, as for all good objects, the press is an agency, not so powerful as the pulpit in the spiritual region, but more extensive and effective in its influence on the mass of mankind. To the last he complained that it was far too much neglected by the Church as a weapon of good. The adjudicators, who were Professor Welsh, Dr. Wardlaw, the Rev. Henry Melvill, Dr. Jabez Bunting, and the Rev. T. S. Crisp, representing all the evangelical Churches,

* Mr. R. A. Macfie, of Dreghorn, who subsequently organized the Liverpool Conference of Missionaries, informs us that these friends were his father; Mr. John Wright, jun., father-in-law of the Rev. Charles Brown, D.D.; and the late Thomas Fairuie, of Greenock, etc. 
awarded the prizes to Dr. Harris, the president of Cheshunt College, and to Dr. R. Winter Hamilton, of Leeds. 'The essays were published, but not in a cheap form which would have sent them into every house; several thousands of both were sold. A catholic narrative and exposition of the foreign missionary movement from the beginning of the eighteenth century to the present day, popular, accurate, condensed, and including Romish missions, is still a desideratum.

When fairly restored to health, towards the summer of 1839 , Dr. Duff prepared himself for the consolidation of all the work he bad been doing during the previous four years towards making the Kirk of Scotland permanently for the future a Missionary Church. He sent out a third missionary in addition to Mr. John Macdonald and Dr. Murray Mitchell; he broadened the movement for female education in the East; he spoke his farewell counsels to the country through the General Assembly; he left his lectures on "India and India Missions," to quicken the missionary spirit in his absence; and he made the final arrangements for giving Bengal a central college worthy of the higher Christian education. In all he had the constant support of Dr. Chalmers, and the friendly hospitality of Dr. Brunton alike in the university and at Bilstane Brae. Of the former we find him thus writing to Sir Andrew Agnew, on the 17th September, 1838: "What triumph attends Dr. Chalmers's career! How ought we to bless and praise our Heavenly Father for having raised up so mighty a champion of truth in troublous times! Truly it is the duty of every one that fears the Lord to lift up his arms as for battle, when the enemy is coming in on every side like a flood. What ineffable consolation in the assurance, 'the Lord God Omnipotent reigneth!" By this time it had 
become evident that the spiritual rights of the Kirk, guaranteed by Scottish Parliament, Union Treaty and Revolution Settlement, were in danger. In May, 1839, Lords Brougham and Cottenham gave the sanction of the highest appellate court to the aggression of a majority of the Scottish judges on these rights. Dr. Duff began to see the purely spiritual work for which a Church exists, which he had done side by side with Chalmers and Guthrie in kirk extension, threatened. In 1839 the revenue of the Church of Scotland for missionary purposes of all kinds was fourteen times greater than it had been in 1834, so that Chalmers exclaimed: "We are planting schools, we are multiplying chapels, we are sending forth missionaries to distant parts of the world, we have purified the discipline, we are extending the Church and rallying our population around its venerable standard."* All this foreign colonial, and home missionary work was to be extended far more largely than fourteen times, by the very ecclesiastical cataclysm which in 1843 seemed certain to extinguish it.

So greatly had the Bengal Mission been extended under Mackay and Ewart, working out Dr. Duff's system with his careful and constant support from home, that they were not satisfied with the addition of a third colleague in the person of Mr. Macdonald. The three clamoured for a fourth to help them to overtake the special field in which no other mission bad then followed them. To their demands Dr. Duff sent this among other replies:-

"Edinbdrgh College, January 15th, 1839.

“My Dear Ewart, - To your last letter I purposely delayed replying till $I$ might have it in my power to

- Memoirs of Thomas Ohalmers, D.D., LL.D. By Dr. Hanna. Vol. ii. chap. 27. 
communicate something of a definite nature on the main practical point therein referred to. The instant - it was received I wrote most urgently to Dr. Brunton, pressing the necessity of immediately appointing a new labourer to support you. Something was spoken on the subject. But lets and hindrances seemed to threaten to retard indefinitely. In December, my own health having much improved, I resolved to visit Edinburgh-first, to consult in person with my medical advisers as to my fitness for immediately returning to Calcutta; and second, in the event of that not being allowed, to enforce the appointment of another. As to the first point, - though satisfied with the progress made on the whole, it was deemed utterly inadvisable to attempt to return till next summer. But, if the Lord will, I have now the certain prospect of turning my face eastward in June or July next. Meanwhile, I have laboured incessantly in pressing the second point, the immediate appointment of another. And I am sure you will rejoice to learn that yesterday, at a meeting of the general committee, not only was it resolved to appoint one, but the individual was actually nominated - and he will lose no time in setting sail to. join you. The new colleague is Mr. Thomas Smith, lately licensed to preach the gospel-one who has long pondered the subject of personal engagement in the missionary cause, though young in years. He has a fine missionary spirit, and in mathematics and natural philosophy was one of the most distinguished students of the session in Edinburgh. He will at once, therefore, be able to lend you effective aid, by taking up any of your own or Mr. Mackay's departments in the scientific part of the course. He will thus relieve you of some of those most onerous duties that have devolved on you in consequence of Mr. Mackay's lamented illness. We have given Mr. Smith to under- 
stand that he may be called on by you to take up the very subjects which constituted Mr. Mackay's share of instruction in the Institution. And I am happy to say that he will be prepared, if deemed proper by you, to do so cheerfully.

"It will not do for a single moment to abate one iota of the educational course. The committee, the General Assembly, the entire Church of Scotland is publicly committed to it. If the Institution at Calcutta be allowed to drop, the sinews of war at home will be cut off, and all the missionaries must either return, or support themselves the best way they can on the voluntary system. At this moment nothing would reconcile the people of Scotland to any measure that would weaken the strength of the Institution. And henceforward, such is the public feeling of intelligent thoughtful people on the subject, that the committee dare not send a missionary who will not pledge himself to join in conducting any department of the educational course which may devolve upon him, either by the judgment of his brethren or the exigency of unforseen contingencies. This does not infringe on the grand design of effecting a thorough division of labour when the number of labourers is complete-each having that department allotted to him in which he is known and acknowledged most to excel-or that which may be his forte. But this is not to be understood as limiting one so exclusively to one particular department as to exonerate him from taking some share in conducting any other when a vacancy may temporarily occur.

"I do not altogether relish the idea of a total separation or chasm being effected between the strictly spiritual and what is called the secular department. Rather, I should say, there ought to be no exclusively secular department. In other words, in teaching any 
branch of literature and science, a spiritually-minded man must see it so taught as not only to prove subservient to a general design, but be more or less saturated with religious sentiment, or reflection, or deduction, or application. In this way, incidentally and indirectly it may be, yet most effectually, may religious impression be conveyed eren when engaged in teaching literature and science. But besides this incorporation of what is religious with what is secular or scientific, there ought no doubt always to be regular systematic instruction in what is biblical and religious. And if in this department any one should be allowed to excel, it would, on the principle of division of labour, be well to allot it to him, but not in such sense as that any other was precluded from teaching religion, or that he was exempted from taking a share in the literary and scientific departments, in case of necessity arising from temporary illness or absence.

"Now, my dear Ewart, there is at my disposal something above $£ 1,000$ in all. Do then send me by the first steamer a complete list of all your desiderata as to books, philosophical apparatus, etc., and I shall endeavour to have all supplied. Do not miss a steamer in sending me as complete a list as you can furnish, that it may reach in time to enable me to avail myself of it before returning to join you. $\mathrm{My}$ affectionate regards to Mr. and Mrs. Macdonald, Mr. Charles, Mr. Meiklejohn, etc. I hope to reply to the old pundit ere long. In haste, affectionately yours,

$$
\text { "Alexander Duff." }
$$

In St. Andrew's Church, Edinburgh, on the 7th March, 1839, Dr. Duff himself presided at the ordination of his young colleague, now the Rev. Thomas Smith, D.D., and the only survivor of the præ-Mutiny band. Dedicated to all students of divinity in Scot- 
land, "with many of whom the author has enjoyed much general converse," the discourse and the charge to the youthful missionary still form not only the most remarkable as it has been the most popular of Dr. Duff's writings, but a model to be studied by all candidates of theology of whatever Church. The missionary a postle himself described it as " a plain letter of instructions which might prove really useful to a young and inexperienced but beloved brother." The epistle has just enough of an autobiographic element to give it a fascination which every year will increase as the events of the decade ending 1839 are thrown farther back in the history of India and of its Church. "Missions the Chief End of the Christian Church; also the Qualifications, Duties and Trials of an Indian Missionary," as the publication of 1839 was entitled, should be edited for republication in its completeness. The latest reprint is sorely mutilated. Many a missionary has that little epistle and charge sent to India, China and Africa from other Churches.

The education of the women of India was begun by young ladies of Eurasian extraction, in Calcutta, under the Baptist missionaries so early as April, 1819. Mrs. Wilson followed, in the same city, in 1822. But Bombay, if later, soon distanced the rest of India, because of the absence of caste among the Parsees, the greater freedom of the social life of the Marathas than that of the Bengalees, and the readiness of Mrs. Margaret Wilson to take advantage of both. Hence, in 1837, a Bombay officer, Major Jameson, began in Scotland the formation of the Ladies' Society for Female Education in the East. Still it was long till, in any part of India, it was possible to bring girls of respectable and caste-bound families under Christian or even secular instruction, with the exception of Parsee ladies. On his first visit to England Dr. Duff was asked to 
supply the Hon. and Rev. Baptist Noel with information, which the preacher published as an appendis to his sermon preached for the Society in London for promoting female education in China, India and the East. He heartily supported Major Jameson's movement in Scotland. On a recent visit to Penicuik wo found in a state of active prosperity the first Ladies' Society seen in Scotland for combined prayer and work for female education in India. That society is the result of an address by Dr. Duff, of which there is no other trace. In the forty years since, it has kept up an intelligent interest in, and has called forth annually increasing work and subscriptions for the evangelization of the women of India, from some of the best families of Midlothian and not a few of the cottages and farms of Penicuik.

Dr. Duff's address at the first annual meeting of the Scottish Ladies' Society, now more vigorous than ever in two bands, not only sketched the position of women in the East under Hindoo and Muhammadan law and practice, but outlined a policy, applicable to Calcutta and Bengal, which he lived long enough to see in full fruition. That has before been sketched in the account of the discussion in Bengalee debating societies, and as an integral part of his missionary educational system. It is most tersely put in these sentences of bis appendix to Baptist Noel's sermon.

"From the unnatural constitution of Hindoo society, the education of females, in a national point of view, cannot possibly precede, cannot even be contemporaneous with the education of males. The education of the former, on any great national scale, must, from the very nature of their position which those only who have been in India can at all adequately comprehend, follow in the wake of the enlightened education of the latter. In a word, $\mathbf{a}$ 
generation of educated males, i.e. educated after the European model, must be the precursor of a genera. tion of educated females."

Should nothing, then, be done? On the contrary, elementary education among the few who may be induced to attend a public school, and during the brief time before marriage and re-absorption into their own idolatrous system, should be zealously prosecuted. Christian philanthropy will care especially for the outcast and the orphan, and the growing class of native Christians must be provided for. "But there is another and far more rapidly increasing one, that must annually swell the aggregate of those friendly to female improvement; the multiform class that aims at the acquisition of European literature and science, through the medium of the English language. From various concurrent causes thousands of native youth have now begun to flock to Government and Missionary Institutions, there to enter on the career of English education; and, if the future keep pace proportionately with the past, these thousands will ere long be multiplied tenfold, and ultimately a hundredfold. Now, it may safely be laid down as an undoubted axiom, that every individual who receives a thorough English education, whether be become a convert to Christianity or not, will, with it, imbibe much of the English spirit, i.e. become intellectually Anglicised; and hence, will inevitably enrol himself in the catalogue of those who assert the right of females to be emancipated from the bondage of ignorance. This is not a legitimate inference only, it is a statement of the results of past experience."

The elementary or direct method has not only rescued thousands of girls from destruction, aiding Government in famines and providing wives for Christian homes; but it has, on the normal school 
method, trained devoted vernacular teachers who were ready to enter the zananas, and to teach the select caste schools, the moment that the indirect influence had prepared the next generation of women to be taught. What Dr. Duff predicted in 1829-18:39 came to pass twenty years afterwards. We shall seo how this policy has led to the caste school and the zanana instruction till at least one Bengalee lady has passed the matriculation examination of the University of Calcutta.

When residing with Dr. Gordon, on the occasion of Mr. T. Smith's ordination, that zealous secretary of the committee suggested to him the delivering of a series of popular lectures in so central a place as St. Andrew's church. Having devoted two or three weeks to the arrangement of his materials, Dr. Duff attracted overflowing crowds in the four weeks of April to hear those gorgeous descriptions, novel expositions, and thrilling narratives which he published for the benefit of the funds of the committee, to whom the book was dedicated, under the title of "India and India Missious : including Sketches of the Gigantic System of Hindooism both in Theory and Practice." The work soon reached a second edition, and has still a historical value, although it may be said that oriental scholarship has come to exist only since the translations of Sir William Jones and the essays of Colebrooke were followed, chiefly after 1839, by the publication of the researches of Burnouf and Lassen, Prinsep and John Wilson, H. H. Wilson and Weber, Max Müller and the brothers Muir. Nor were Duff's lectures confined to Edinburgh. We have traces of him in Liverpool, both in the Philanthropic Hall and in the Collegiate Institution, where Dean, then Principal, Howson induced him to deliver one described by a critic as "of remarkable brilliance and power." 
The General Assembly of 1839 brought with it, for Dr. Duff, the solemn but not sad duty of saying farewell to the country and the Church. As a member for his native presbytery of Dunkeld he spoke again, but with fresh power and new facts, "on the subject of your great missionary enterprise." The contrast between the past and the present in the highest court of the Kirk was so striking that he recalled the time when the venerable Erskine cried out, "Rax me the Bible," that he might prove to his brethren in the ministry the duty of preaching the gospel to the heathen. Against that memorable incident, only a generation past, he set the record of converts and Hindoos about to become themselves missionaries, as given in the latest report of the India mission. Saddened for the moment that he was leaving no eyewitness behind him to feed with facts and appeals the home machinery he had organized, he said, "Public meetings alone will never answer our end. We must descend to the mass and permeate with vitality its humblest and most distant atoms. Without this all our missionary, educational, and church extension schemes must flag and fail. You must get the young on your side," he said; "give me the school books and the schoolmasters of a country, and I will let any one else make not only its songs and its laws, but its literature, sciences and philosoply too! What has made Brahmanism the hoary power it is but its Shasters? What has sustained the force and passion of Islam for centuries but the Koran" read in every school and college from Gibraltar to the Straits of Malacca? So must Christians use the Press, after his outburst on which he referred to his own departure :-

"Already is it the boast of our country, that it has replenished the service of our sovereign with warriors and statesmen; supplied every civilized nation with men accomplished 
in learned professions; filled the exchanges of every metropolis in the globe with enterprising capitalists; sent intrepid adventurers to explore the most barbarous and inhospitable climes. But let us, through the medium of works for the young, and especially of school books universally adopted, only saturate the juvenile mind of the nation with evangelistic principles, duties, and motives, and our country may be destined to earn yet greater and more lasting fame. Our parochial schools may become the rudimental nurseries, and our colleges, and especially our divinity halls, the finishing gymnasia of a race of men who shall aim at earning higher trophies than flags and standards rolled in blood-nobler badges than mimic stars of glittering dust;-a race of men, on whom shall fall the mantle of the Eliots and the Brainerds of the West, and the Martyns and Careys of the East.

“. . . Often, when wearied and exhausted under the debilitating influences of a vertical sun and a burning atmosphere: often, when depressed and drooping in spirit, amid the never-ending ebullitions of a rampant heathenism: often, when thus made, in some measure, to realize the feelings of the exiles of old, who by the streams of Babel did hang their harps upon the willows, and wept when they remembered Zion-often, often I have retired to the chamber of meditation, on a table of which constantly lay a copy of 'the Cloud of Witnesses;' and after perusing some of the seraphic utterances of our Renwicks and Guthries, from the dungeons and the scaffolds of martyrdom, often have I fallen down before the divine footstool, ashamed and confounded on account of my faint-heartedness and cowardice; and rising up, new-braced and invigorated in the faith, as often lave $I$ been made to resolve, through grace, to be so faint-hearted and cowardly no more. But little did I then think of the fresh impulse and enjoyment that awaited me, when subsequently privileged to visit those regions of our native land, that may well be termed the Judøa and Jerusalem of persecuting times. I have been in temples of the most gorgeous magnificence; I have been in palaces decorated with the glittering splendours of art; I have been in bowers gladdened with perpetual summer, and clothed with never-dying verdure;-but never, never amongst them all have I experienced the same pure and elevated and ecstatic emotion as within the last two years, 
when traversing those bleak and dreary upland moors, and barren mountain solitudes, that often constituted the only home of those devoted men of whom the world was not worthy-that have been consecrated in the eyes of posterity as their birthplace and their graves; and over every moss, and rock, and dell of which once waved the banner emblazoned, as if in rebuke of the treason and blasphemy of latter days, with the glorious inscription,-

“ 'For Reformation

In Church and State,

According to the Word of God,

And our sworn Covenants.'

"Now, these are the men whose example we are ever and anon called upon to imitate. But surely, if there be any one point more than another in which they have set us the most emphatic example, it is in their cheerful determination to deny themselves and submit to all manner of sacrifices. Can we, except in derision, be said to emulate their conduct, if not prepared and resolved to submit to like sacrifices with them? If all were here present this day, whether clergy or laity, who glory in being the members of a Church that has been watered and cemented by the blood of martyrs, might we not demand, - What substantial proof or pledge have ye ever yet given that ye are really prepared and resolved to tread in their footsteps? You profess to imitate their example! Well, in order to this, you are called upon, like them, to deny yourselves, in order the more effectually to advance the cause of the Redeemer.'

"In the spirit of this resolutiox I originally went forth to heathen lands. And though suddenly removed by an affictive visitation of Providence, over which I had no control, the spirit of that resolution still abideth the same. If the Lord will, therefore, my unaltered and unalterable purpose is, to return to the scene of my former labours. In adhering sc determinedly to this purpose, I am not unaware of the misconstruction and ancharitable insinuations to which, in certain quarters, my conduct has been subjected. Now, though in myself I feel and confess that I am nothing, yea, 'less than nothing, and vanity,' I must, for the sake of ' magnifying my office,' be permitted to assert and vindicate the integrity of my actuating motives. I would return to the land of my adoption, 
not because, in the gross and carnalising judgment of some worldlings, I could not do better at home. No ; if the earnest and reiterated entreaties of friends; if the most alluring offers, on the part of some of 'the mighty and the noble;' if the most tempting invitations to spheres of honour and responsibility, from not a few of the Christian people of this land,could have availed aught, I might, in the low, vulgar and drivelling sense of the expression, have done better at home. I would go, not from the restless spirit of wild, roving adventure. If the animating principle had flowed from that source, sure enough it ought by this time to have been cured, in the case of one who twice suffered shipwreck, barely escaping with life; who, more than once, was well-nigh foundered amid the gales and hurricanes of the deep; and who was thrice brought to the very brink of the grave by the noxious influences of an unfriendly clime. I would go, not from any exaggerated estimate or ambitious longings after the pomp and luxuries of the East. No. Dire experience constrains me to say, that, for the enjoyment of real personal comfort, I would rather, infinitely rather, be the occupant of the poorest hut, with its homeliest fare, in the coldest and bleakest cleft that flanks the sides of the Schehallion or Ben Nevis, than be the possessor of the stateliest palace, with its royal appurtenances, in the plains of Bengal. I would go, not from any freaks of fancy respecting the strangeness of foreign lands, and the exciting novelty of labour among the dwellers there. There I have been already; and can only testify that the state of the heathen is far too sad and awful a reality to be a fitting theme for story or for song, - unless it be one over which hell would rejoice, and heaven weep. I would go, not from any unpatriotic dislike of my native land, or misanthropic aversion from its people, or its institutions. No : for its very ruggedness, as the land of 'the mountain and the flood,' I cherish more than ordinary fondness. How could it be otherwise? Nestled and nursed, as it were, from earliest infancy, among its wildest and sublimest scenes:-no pastime half so exhilarating as the attempt to outrival the wild goat in clambering from crag to crag, or to outstrip the eagle in soaring to their loftiest summits; no music half so sweet as the roar of the cataract among the beetling precipices of some dark frowning ravine or solitary dell ; no chariot and equipage 
half so much coveted as the buoyant wreaths of mist that scoured athwart the scalped brows, or curled their strange and fantastic shapes around the ragged peaks of the neighbouring hills. Hence a fondness for the characteristic scenery of my native land, amounting almost to a passion-a passion which, like every other, it requires divine grace to modify and subdue. For oft as I have strayed among gardens and groves, bestudded with the richest products of tropical climes, the involuntary ejaculation has ever been, 'Give me thy woods, thy barren woods, poor Scotland!' Towards its people I have always cherished the fondest attachment-an attachment vastly augmented by the circumstance, that from Pomona, the mainland of Orkney, to the Solway Firth, there is scarcely a city or district in which I could not point out one or more personal friends, in whose Christian society I have found refreshment and delight. Of all its institutions, sacred and civil, I have ever entertained an unbounded admiration - an admiration that has been immeasurably enhanced by the contrast. which the want of them exhibits in other lands. I would therefore go, not because I love Scotland less, but because I humbly and devoutly trust that, through the aid of divine grace, I have been led to love my God and Saviour, and the universal extension of His blessed cause on earth, still more. I would go because, with the Bible in my hands, I cannot see what special claim Scotland has apon me, as a minister of Christ, any more than any other land embraced within the folds of the everlasting covenant; because, with the Bible in my hands, I cannot see how a soul in Scotland can be intrinsically more precious than a soul in Greenland, or Kaffirland, or Hindostan, or any other region on earth; because, with the Bible in my hands, I cannot see that the bounds of the Church of Scotland are identical with the bounds of the Redeemer's kingdom; or that the Lord Jesus, who is no respecter of persons, is the Redeemer of Scotlaud rather than of any other realm included in the emphatic and catholic designations of 'all the world,' and 'all nations.' '”

While thus entitled to be exacting, in his Master's interest and their own, towards others because ho was not sparing of himself, the missionary was no less 
generous in his acknowledgment of those who did their duty. Mr. Baptist Noel had shown that in the year 1834, when the whole income of the United Kingdom was estimated at about 514 millions sterling, the proportion assigned to missions and Bible societies of all kinds was only one seventeen-hundredth part, or $£ 300,000$. Dr. Duff told of individuals, and especially Christian ladies, who had become his fellow-helpers in the gospel. One lady in London raised $£ 500$; her example led two at Inverness to collect $£ 1,000$ in pennies, every one of which meant so much intelligence, prayer and faith; and another aided the new colonial scheme by supplying with four ministers the thirty thousand Scotsmen then in the island of Cape Breton. Still another sent him $£ 500$ in an anonymous note, as "from one who, having felt the consolations of the gospel, is most anxious these should be imparted to the perishing heathen." Thus was the Government price of the site $(£ 1,600)$ for the new college in Cornwallis Square contributed; thus was the building raised; and thus, as we have seen from the letter to Dr. Ewart, were a library and philosophical apparatus supplied for the use of its students. Into this college building and equipment fund, destined to an unexpected fatethe disruption of $1843-\mathrm{Dr}$. Duff poured a sum which many to whom he had been blessed offered him in vain as a personal gift for his family. All that he would

- Thus described by Dr. Duff: "One of the most peculiar attempts was that which originated with the Misses MacIutosh, of Raigmore House, Inverness. Their father had been the founder of one of the six great commercial and banking-houses in Calcutta. The scheme was to interest parties in every parish in Scotland so as to realize by pennies the snm of $£ 1,000$. Through indefatigable exertions, at length the object was really accomplished, and in carrying it out no doubt a vast deal of fresh interest in the mission was diffused throughont the membership of the Church." 
consent to, of a personal nature, was the publication of his portrait, painted by William Cowen, and engraved, in mezzotint, by S. W. Reynolds. The original is now in Calcutta.

He who had stood alone in Calcutta in 1830 now saw eight other missionaries from the Church of Scotland in India all working on his system with an enthusiasm fired by his own. And he did not stop there. Dr. Guthrie had been called to the church of Old Greyfriars in Edinburgh which he himself had refused, and had been there only two years when he wrote: "I had Duff and some others dining with me the other day. Duff was keen for me to go out to India. Dunlop declared that Lord Medwyn would take out a prize warrant, seeing that he is risking some five or six hundred pounds in the new church (St. John's), on the understanding that I was to be minister thereof." Ten years after, when Guthrie broke down from overwork, Duff thus wrote to him from Calcutta: "The whole of your remarkable career during the last few years I have been following with intense delight; your Manse scheme and Ragged School have been bulking before my mind's eye in a way to fill me with wonder, aye and devout gratitude to the God of heaven for having so extraordinarily blessed your efforts. From my own experience I find that a season of affliction and inward humiliation usually precedes some development of spiritual energy in advancing the cause of the Lord." Puzzled by his refusal of any personal recognition of his services at home, friends on both sides of church politics begged that Dr. Duff would at least meet them at a public dinner or banquet. With his answer many who have been victims on such occasions, alike in giving and receiving honour, will sympathise: "Farewell dinners," he said, "were nerer to my taste. I have always shunned them in the case of others, and 
I will not myself be the object of honour. They are generally attended by a mass of stereotyped phrases intended to be flatteries but without honest meaning. But hold a religious service, and ask Dr. Chalmers to give me his fatherly counsel and admonition." And so it came about that, though the great preacher's ordination charge to Duff has not seen the light, we have his matured opinion on the Scottish missionary system, from the economics of which he received many a hint for his own Free Church creation three years after. Dr. Hanna has reprinted the farewell charge of 1839 in the "Sermons illustrative of different stages in his ministry," by the man whom Mr. Gladstone has pronounced the grandest of all preachers he has heard, in spite of a distasteful accent, although John Henry Newman was one of those preachers.

"Ten years ago," said the divinity professor of sixty to the already experienced missionary of thirty. three who stood before him above a vast crowd in St. George's, Edinburgh, “ in the work of setting you apart to your office I expatiated on the nature and evidence of conversion to God. 'As we have heard, so have we seen in the city of the Lord of hosts, in the city of our God : God will establish it for ever.' Christianity is the manifestation of truth by the Spirit to the conscience. It is on some such moral evidence. that the philosophy of missions is based. As we have heard, so have we seen : then may it be understood how, without a sensible miracle, there may arise in the mind a well-founded belief in the truth of Christianity." Thus had the first missionary of the Church of Scotland devised his plan and carried out the divine policy - "faith cometh by hearing, and hearing by the word of God."

"By a device of admirable skilfulness and correspondent success, you have brought many of the most influential families 
of Hindostan within reach of the hearing of the word of God. You hare instituted a school mainly of scriptural lessons and ecriptural exercises. You have practised no deceit upon the natives, for all is above board, and it is universally known that the volume which forms the great text and substratum of your scholarship is the book of the religion of Christians. But you, at the same time, have studied to multiply the attractions of this school; you have not only instituted a lectureship on the evidences of Christianity, but, for the purpose of engaging the attendance chiefly of the higher classes, you have pressed into the service both the physical and the mathematical sciences, and, what might startle some, have superadded the doctrines of political economy, and all that the votaries of science might be lured within the precincts of sacredness. It is thus that many of India of all ranks, and especially of the upper orders of society, have passed through your seminary in successive hundreds, familiarized with the language and seasoned with the subject matter of inspiration. It is thus that many have heard with the hearing of the ear, and at least been disarmed of all hostility to the gospel, and some of these, many, have been made to see, and been converted, and become the declared friends and champions of our faith. It delights me, sir, to know, as the fruit of my intimate converse and of my acquaintance with your principles and your thoughts, that while sou have done so much to obtain an extensive hearing for the gospel of Jesus Christ in the most likely and promising quarters of human society, you are at the same time fully and feelingly aware what that high and external quarter is whence alone the seeing comes, and that unless a blessing, to be evoked only by prayer, shall descend from the sanctuary above upon your enterprise, all the labour you have bestowed upon it will prove but a vain and empty parade. Let me earnestly recommend the continuance of this sacred and fruitful union, a union between the diligence of ever-working hands and the devotion of everpraying hearts. Men of various moods and temperaments, and different tastes of spirituality and intellect, will be rariously affected by the spectacle. Those of shrewd, but withal of secular intelligence, will think lightly of your supplications, perhaps even speak contemptuously of those outpourings of the Spirit on which, I trust, you will ever wait and ever watch 
with humble expectancy. Those of serious, but withal of weak and drivelling piety, will think lightly of your science, and perhaps even speak with rebuke of your geometry, and your economics, and your other themes of strange and philosophic nomenclature, as things that have in them a certain cast of heathenish innovation, prejudicial to the success, because incongruous with the simplicity of the gospel. But amid these reproaches on the right hand and on the left, persevere as you have begun; and whether, on the one hand, they be the cold rationalists who assail you with their contempt, or, on the other hand, they be the fanatical religionists who look on you with intolerance, continue to do what all men of sense and of sacredness have done before, and you will at length reap the fulfilment of the saying, that wisdom is justified of her children."

Having thus put his imprimatur on the system in language as strong as even Dr. Duff's when the missionary vindicated his evangelism alike against "the bigotry of an unwise pietism" and "the bigotry of infidelity," Dr. Chalmers spoke with an almost predictive reference to his own coming scheme of Free Church economics, when he said, "You were the first, I believe, to set the example of passing from parish to parish, and from presbytery to presbytery in behalf of your own cause, and it only needs to be so carried forward in behalf of other causes as to fill the whole length and breadth of the land, in order to reap a tenfol $\dot{\alpha}$ more abundant harvest from the liberalities of the people than has ever yet been realized." Referring to his special work of home missions as not a competing but a co-operating cause, he nttercd a truth which his successors have generally though not always remembered: "Our two causes, our two committees, might work into each other's hands. Should the first take the precedency and traverse for collections the whole of Scotland, the second would only find the ground more softened and prepared for an 
abundant produce to itself. It acts not by exhaustion -it acts by fermentation." And with this glimmering of the certain glory, be a second time sent forth his favourite disciple and now beloved brother; referring to "the singularly prophetic aspect, not merely of the days in which we live, but both of Christendom, that region you are about to leave, and of Eastern Asia, that region of ancient idolatry whither you are going; for we can notice on that distant horizon the faint breakings of evangelical light which, like the dawn of early morn, may perhaps increase more and more till the drying up of the Euphrates that the way. of the kings of the East may be prepared."

We find this note written to Dr. Chalmers before the address :-

"Bilstane by Loanhead, Tuesday, 8th.

"My Dear Sir,-I thank you with all my heart for your very kind note of this morning. To receive from you anew in any form the address of ten years ago-the material of which became food for the white ants of Bengal, but the moral of which had been previously incorporated into my mental constitutionwill be to me an invaluable boon.

"I am grieved to say that I had a pre-engagement for breakfast on Thursday morning, of such a nature that I cannot suspend it. But, if possible, I shall endeavour to call on you between ten and eleven o'clock, a.m. I cannot express the gratification, the comfort, the invigoration of spirit which I have experienced in the very prospect of your giving me a parting address on Thursday, for to you I feel more indebted, as an instrument in the hands of God, for the impulse that carried me to heathen lands, than to any other in the form of mere man. With grateful, affectionate regards,

"Alexander Duff." 
Dr. Duff preached his farewell sermon to his own people, in the Moulin parish kirk of his childhood, from the text, "Finally, brethren, farewell." The services, Gaelic and English, lasted for five hours, and the crowded audience were in tears. On the subsequent Monday evening he met with them again, and, after a short address, shook hands with the minister in the name of all the country people, who had flocked in from the vale and the hillsides of Athole. Then followed the living martyrdom of Indian exile, the parting of father and mother from their four children. The birth of the youngest, a boy, only a few months before, had kzen to Dr. Duff a source of new joy and strength at a time of depression. Parents and children were not to meet again for eleven long years. 


\title{
CHAPTER XIII.
}

\author{
$1839-1840$. \\ EGYPT.-SINAI.-BOMBAY.-MADRAS.
}

T/aghorn and the Overland Route--Dr. Duff as a Traveller.-Harwich to Civita Vecchia with Cardinal Wiseman.-The Light Wines of France.-Syra.-Alexandria.-Mubammad Ali and the Church of St. Mark.-The Pyramids and Memphis.-Dr. Duff on the Pasha's Miggovernment of Egypt.-Interview with the Coptic Patriarch.-Caravan to Siez and an Indian of the old School.Dr. Duff goes alone to Sinai.-Justinian's Convent of St. Catharine.-Greek and Hindostanee.-A Christian Sabbath on the Mount of Moses.-Letter to his Danghter.-Snez.-Bombay.Meeting with Wilson and Nesbit.-The Differing Conditions of Western and Eastern India as Missionary Fields.-Comparative Backwardness of English Education in Bombay.-The Scottish Missions and Missionaries there.-Ronnd Cape Comorin to Madras -A Night with Samuel Hebich at Mangalore.-The Scottish Mission in Madras.-A Cyclone at the month of the Hooghly.-Cálcutta again.

The Overland Route, a phrase which has ceased to have any but a historical meaning since the opening of the Suez Canal, had just been made a fact when, in the autumn of 1839 , Dr. and Mrs. Duff went forth to India for the second time. On the ordinary roll of the English martyrs of science the name of Thomas Waghorn is not to be found. It has been left to the French to do justice to the memory of the man who, amid obstruction, obloquy and injustice ending in a pauper's death, first opened the British overland route to India in 1830. When M. Ferdinand de Lesseps created the consequent of that by cutting the canal 
between the Red Sea and the Mediterranean in 1870, his first act was to erect, at the Red Sea entrance, a colossal bust of Waghorn on a marble pedestal, with basrelief of the explorer on a camel surveying the desert, and this inscription: "La Compagnie Universelle du Canal Maritime de Suez au Lieutenant Waghorn." We have never passed that statue without a sense of shame-and of gratitude to the genius of the catholic Frenchman., In 1830, the quondam midshipman of the navy, who had become a Bengal pilot, sailed down the Red Sea in an open boat with despatches from Lord Ellenborough to Sir John Malcolm. He took four months and twenty-one days to make the journey from London to Bombay, because all the authorities except Lord William Bentinck scouted him as a monomaniac; yet he beat the Cape ships of the time, and his voyage was pronounced " extraordinarily rapid." For ten years thereafter he wasted his life and his means of living in attempting to convince the Company, which snubbed the Governor-General for sending the Hugh Lindsay steamer to Suez in a month; and to conciliate the king's Government, which sent Colonel Chesney to discover a short way by the Euphrates and the Persian Gulf. The bluff English sailor triumphed, but only to see all the fruits of his victory snatched by the Government which had scorned him, and for very shame at last threw him a miserable pension which was at once seized by his creditors. Thomas Wag-

In the eight jears ending 1878 , the number of vessels which have passed through the Suez Canal has been 10,988, yielding eight millions sterling in dues. Of these vessels 8,007 were British, which paid six millions sterling ont of the eight. In the last year, 1878 , of 96,363 passengers who passed through the Canal in 1,593 ships with a measurement of $3,269,178$ tons, besides the many who crossed the isthmus by railway, 28,339 were British soldiers and 14,775 Anglo-Indians, or 43,114 in all. 
horn died in the misery of debt, while the Peninsular and Oriental Company sent its first steamers, in 1843, along the path he had persistently tracked out. To complete the scandal, not seven years bave passed since his aged sisters were driven to ask the public for support, while the Government which had so ruined their brother raised a revenue of fifty millions sterling a year from India and paid nearly half a million in subsidies for the postal traffic on his overland route. So it is that the Latin poet's experience is still true"Sic vos non vobis.". The bees of humanity make honey, but not for themselves.

When Dr. Duff resolved to return to India by what was, in 1839, still Waghorn's overland route, he knew the story of the heroic pioneer so far, and he resolved to run the risk. "A man above the common for activity, energy and enterprise!" was his admiring exclamation then, before the eager life had been made a miserable tragedy by an ignorant country and an ungrateful Government. Hotels in Egypt, swift horse vans instead of camels in the desert, and a steamer with cabin accommodation for twelve passengers, were the marvellous facilities supplied by this national benefactor in such circumstances. Thus he had converted the nearly five months of 1830 into the month and a half of 1839 between London and Bombay, just as he pointed the road to the present reduction of the time to sixteen days. Dr. Duff bad to find his way first to Bombay, at the request both of Dr. Wilson and the Kirk's committee, that he might comfort and counsel his colleagues there after the keen excitement caused by the baptism of the first two converts from Parseeism. His most rapid course thus lay from Harwich to Antwerp and Brussels, south by Paris to Marseilles, and thence by steamer to Syra, there to join the mail steamer from Constantinople to Alexandria. 
As a traveller Dr. Duff always showed more than the apparent restlessness of the Anglo-Indian. By reading and conversation with those who had gone over his route, he prepared himself for the intelligent enjoyment of new lands and peoples. To the ardour of the boy he added the endurance of manhood and the broad culture of the genial student. Nothing sacred or secular escaped his observation, but his letters, while they delighted those who were less travelled, fell far short of his conversation, under the occasional stituulus of cross-examination. Then his talk was at its best, whether he told of the political condition of a country like Italy, of the benevolent enterprises of the Protestants of France and Switzerland, or of the numerous mishaps of a tour in the wilds of Scandinavia.

We may pass rapidly over the European portion of his outivard journey. At dinner in the Harwich steamer he was attracted by the remarkable intelligence of an English gentleman, on his left-hand, who showed unusual familiarity with the literary and scientific questions of the day. They parted on landing at Antwerp, when, on visiting the great cathedral to see the master-pieces of Rubens, he observed his new acquaintance bent almost prostrate before an image of the Virgin. He then discovered that the attractive talker was Dr. Wiseman, already known as a Syriac scholar and fresh from his controversy with Dr. Turton in that eucharistic branch of the Tractarian movement from which he expected even greater fruit than Rome has gathered. Dr. Wiseman was on his way to Rome, where he had been rector of the English College, and was about, as bishop, to take the first step to the coreted position of the seventh cardinal whom England had seen since the Reformation. At Antwerp Dr. Duff observed the traces of the wealth created by the flow of the trade from India along the 
earliest overland route-by Solomon's cities in the desert, the Danube and the Rline to the Dutch East India Company's docks. In Brussels, "so strangely mixed up with the intricate web of British history," and still more in Paris, he marked "the combineu' idolatry of sense and intellect" which more than ever attracts worshippers from every land. As he went on to Chalons-sur-Saone, Melun recalled Abelard to him. The wealth of the wine country throngh which he was slowly driven suggested such reflections as these, of even more significance to our own time than they were forty years ago :-

"In these countries, mantled with vineyards, one cannot help learning the true intent and use of the vine in the scheme of Providence. In our own land wine has become so exclusively a mere luxury, or, what is worse, by a species of manufacture, an intoxicating beverage, that many have wondered how the Bible so often speaks of wine in conjunction with corn and other such staple supports of animal life! Now, in passing through the vineyards in the east of France, one must at once perceive that the vine greatly flourishes on slopes and heights where the soil is too poor and gravelly to maintain either corn for food or pasturage for cattle. But what is the providential design in rendering this soil-favoured by a genial atmosphere-so productive of the vine, if its fruit become solely either an article of luxury or an instrument of vice? The answer is, that Providence had no such design. Look at the peasant at his meals in vine-bearing districts! Instead of milk he has before him a basin of the pure unadulterated 'blood of the grape.' In this, its native and original state, it is a plain, simple and wholesome liquid, which at every repast becomes to the husbandman what milk is to the shepherd,-not a luxury but a necessary, not an 
intoxicating but a nutritive beverage. Hence, to the vine-dressing peasant of Auxerre, for example, an abundant vintage, as connected with his own immediate sustenance, is as important as an overflowing dairy to the pastoral peasant of Ayrshire. And hence, by such a view of the subject, are the language and the sense of Scripture vindicated from the very appearance of favouring what is merely luxurious or positively noxious, when it so constantly magnifies a wellreplenished wine-press, in a rocky, mountainous country like that of Palestine, as one of the richest bounties of a gracious Providence-not to the rich or the mighty of the earth, but to man, as man, with his manifold physical wants and infirmities."

The sail from Chalons down the Saone took the travellers into the heart of scenery like their own Scotland, but with a climate more congenial to the Anglo-Indian than the gloom and the grey of the cold North. Past Roman ruins and fairy-like villas, Rousseau's valley of Rochecardon and Lyons of martyr memories, - where a day of refreshing intercourse was spent with the evangelical pastor, M. Cordés,-they were swept on by the rapid Rhone two hundred miles in twelve hours to papal Avignon; thence Marseilles and its steamer were reached. On the calm bosom of the Mediterranean, the Presbyterian and very catholic missionary and the Roman Catholic Dr. Wiseman were glad to renew their talk. The magnificence of Genoa - the first ' city of palaces'-from the sea, with the setting sun bathing it in gold, gave place to the gentler beauty of Leghorn, framed as it were in the Western Apennines, and that to the low land and fever-stricken swamps of the neighbourhood of Civita Vecchia. As they coasted along the ancient Etruria, their talk was of the discovery of ancient urns in its hills. Here Dr. Wiseman was a master, and he courteously guided 
his travelling companion to the nearest eminence where the treasures of ancient art had been found. At the then papal port they parted never to meet again, the English priest to his episcopal consecration and cardinal's hat in due time, the Scottish missionary to his turning upside down of the idolatries of the far East.

The Marseilles steamer then called at Malta, passed within a hundred yards of the precipitous headland of Cape Matapan, and dropped anchor at Syra, the port of Europe which is nearest to India. The filth and the vice of a Levantine albeit Greek centre contrasted painfully with the glories of Homeric and even later days. The steamer from Constantinople had Colonel Hodges, the new British Consul-General for Egypt, on board, and also the Rev. Mr. Grimshaw, rector of Bedford, and known in his day as the author of a life of Cowper the poet. On reaching Alexandria they found that the last act of the departing ConsulGeneral, Colonel Campbell, would be to lay the foundation stone of the first English church, of St. Mark, which now adorns one corner of the great square. Dr. Duff learned that the ceremony was to be of a purely civil character, in this Muhammadan city, with its memories of Pantænus and Clement, of Origen and Athanasius, and sought an explanation of the anomaly. Colonel Campbell was a great favourite with the enlightened Muhammad Ali, the irresponsible ruler of Egypt. Being religiously disposed, the ConsulGeneral had felt the need of a Protestant place of worship in a city like that of Alexandria, which was daily becoming a greater thoroughfare between the West and East than it had been since the time of its founder. Though himself a Presbyterian, he did not want it to be exclusively Presbyterian : he knew that members of all Protestant Churches would often be 
passing through and there be often detained for days. What he wanted was a Protestant Cluurch on a purely catholic basis, so that he might freely invite any minister of any Church to conduct divine service there. $\mathrm{H}_{\theta}$ had repeatedly therefore asked his friend the Pasha for a piece of ground, outside the walls of Alexandria, on which such a church might be erected.

Muhammad Ali frankly declared that personally he had no prejudice on the subject, but the religious heads of Islam at Constantinople would resist the attempt. At his farewell interview with the ConsulGeneral, however, he said, with a smiling countenance: "Colonel Campbell, you and I have always been fast friends. You have often greatly helped me with your counsel, and in other respects have done me good service. You know that in the East the custom is for a ruler to make his friend a present of a piece of land, commonly called 'jagheer,' to be in perpetuity his own property. I want to give you a small portion of the space occupied by the great square in Alexandria, very near its centre. It is my parting gift to you, only you must ask me no question as to what use you may make of it, as that may involve me in official trouble. But I tell you plainly, you may use it for whatever purpose you think proper." Colonel Campbell thoroughly understood the Pasha, thanked him with all his heart, and soon made over the land to a committee of the English residents as the site of the first English church. Muhammad Ali went further. He could not himself be present, but he sent his chief officers of state and his body-guard to honour his friend on the occasion of laying the foundation stone. All the consuls, all Alexandria, were to be present. How could a religious service be attempted in such circumstances?

Colonel Campbell came to see that, even in Oriental 
eyes, the dedication of a site for the worship of God without the recognition of the presence of God would be a scandal, or a cause of suspicion. Accordingly on the 14th December, Dr. Duff--described in the Globe newspaper of the time as "a missionary of some celebrity in India, who happened to be present in Alexandria-perfo' ned the religious part of the ceremony, in which he was followed by the Rev. Mr. Grimshaw." Since that occasion Dr. Yule has raised a Scottish church near the square, and M. de Lesseps has had his canal cutting blessed by prelates of all the Eastern Churches side by side with Muhammadan Moulvies. But never before or since has the Egypt of Fatimite caliphs and Turkish pashas heard publicly read in its greatest place Solomon's dedication of the first Temple and the prayers of Protestant ministers from West and East. "It was quite remarkable to note," wrote Dr. Duff, "the stillness, respectfulness, and earnestness with which the whole mass of surrounding Mussulmans, only a few of whom could understand English, listened to the prayers, the reading, and addresses, and then quietly dispersed. Such was the noble catholicity of the Protestant church, as projected and practically established by Colonel Campbell." In two interviews with Muhammad Ali thereafter, Dr. Duff pressed upon the Pasha the importance, for industrial as well as other reasons, of attracting the Jews back to Palestine, for the Pasha was at the time master of that part of Syria.

By dahabieh up the Mahmoodieh canal, excavated in 1820 by cruelly forced labour, and slowly up the Hooghly-like Nile of the Delta, Cairo was reached, only to find that there were sixty passengers to fill the twelve berths of the small steamer to Bombay. This gave Dr. Duff a whole month, in which he not only visited the pyramids of Geezeh and Sakkara, and explored 
Memplis from the ancient cemetery, of which Sir G. Wilkinson's Arabs were busily laying bare the mummy pits, but carefully studied the condition of the unhappy fellaheen of Egypt, and afterwards went to Mount Sinai. Familiar with Bengal and with the British financial and administrative systems, the farseeing missionary formed impressions regarding the rule of Muhammad Ali very different from those which were popular at the time, but too sadly confirmed by the subsequent history of Egypt to the present hour. Indeed, having many times passed through the land, from the days of the vans in the desert to those of the canal steamer and the new railway, we can find no more correct description of Egypt as it was than that of the Bengal missionary in 1839, and no more faithful account of Egypt as it is than that of the Bengal Lieutenant-Governor, Sir George Campbell. The one unconsciously confirms the other. Both independently show the hopelessness of Mussulman rule under the very best conditions.

After an eloquent description of Cairo, full of the life and colour of the confused oriental scene which Parisian taste has now covered but not cleansed, and the exposure of a great magician whose spiritist arts made him the talk of the East, Dr. Duff wrote in the Calcutta Christian Observer of 1840, that the hope of a revival of Egypt under the new Pasha was a delusion.

"That the Pasha is one of the most extraordinary men of his age-a man of uncommon talent and energy of character; a man, too, capable of being courteous and affable in the extreme-is universally conceded. But that he is, in any sense, the real friend or regenerator of Egypt, is belied by every one of his actions. Self, self, self, is with him the all in all. Personal fame, personal power, and personal aggran- 
dizement, circumscribe the entire horizon of his policy. On the details of his well-known history it is needless to dwell. Born of a humble parentage at Cavallo in Albania, in 1769, he for some time acted as an assistant collector of taxes, and afterwards as a tobacco merchant. Having been twice admitted to his immediate presence, it wonderfully struck us that his whole appearance still pointed very significantly to the lowliness of his origin. Of middle stature, inclined to corpulency rather than corpulent, he exhibited in his countenance nought of real greatness, dignity, or command. Indeed, the entire expression of it was decidedly of a sharp, harsh, and vulgar cast; its chief redeeming quality being its venerable beard. But those eyes-were they not striking? Yea, verily; such a pair of flashing eyes we never saw. It seemed as if their possessor could penetrate through one's bodily frame, and at a single glance read the most secret thoughts and intents of the heart. Still it was not the piercing glance of a profound intelligence which mainly lightened through these eyes: it was rather the vivid flash of a tiger-like ferocity. Hence, doubtless, his favourite oath, when bent on some deed of more than ordinary horror, 'By my eyes!' When he spoke, his voice had a peculiar shrillness which made one feel uneasy; and when he smiled, his very smile had somewhat in it of a savage grin."

Dr. Duff showed in detail, in agriculture, in manufactures, in public works, in commerce, in military discipline, and in the aggravated horrors of the slavetrade, that all the changes amounted to neither \& reform nor a regeneration, but to the oriental art of squeezing the peasantry that the ruler might have a full treasury and a ruthless army. The solitary printing-press and polytechnic school were "in point of fact, as much the mere instrument of an all-absorb. 
ing despotism as the drill ground, the cannon foundry or the powder mill." Then, as all through the debasing history of his house, while it is true that Muhammad Ali and his successors have been capable of occasional acts of generosity, the remark of their French panegyrist sums up the truth :- " The traveller sees with astonishment the richness of the harvests contrasted with the wretched state of the villages. If there is no country more abundant in its territorial productions, there is none, perhaps, whose inhabitants on the whole are more miserable." Forty years of that misery have slowly passed, handing it on in an intensified form to a new generation, from whom Christian bond-holders still demand the pound of flesh, while the Western Powers are foiled in the attempt to keep the fellabeen quiet, only, let us hope, to hasten the day of their deliverance.

Dr. Duff could not be in Egypt without studying the most degraded of all Christian churches except its Abyssinian offshoot, the Coptic. Very tender is the sympathy, very eager the hope, which he expresses in its case. Then the only missionaries in all Egypt were Messrs. Lieder and Krusé, the former and his wife long the benefactors of its people, and the friends of all Christian travellers who sought them out. Now American Presbyterians like Dr. Lansing, as well as others, have done in Cairo, and from Ramleh to the equator, the same work among Copts and Arabs that Dr. Duff had been doing among Hindoos and Muhammadans. "Roused by recollections of faded glory, we felt moved with a burning desire to know how life could be rebreathed into the shrivelled skeleton of so fruitful and so noble a mother of churches," wrote Dr. Duff. The Patriarch, professing to be the apostolic successor of St. Mark, had been conveyed from his convent to the chair of the Evangelist by 
the soldiery of the Pasha for consecration! Dr. Duff songht an interview with him, that he might urge the gradual establishment of a college like that in Calcutta-a scheme since most successfully carried out by the Americans. He and Mr. Grimshaw were conducted to the audience chamber by the Bishop of Jerusalem.

"There the Patriarch, a dark-complexioned, venerable old man clad in his pontificals, was seated in oriental style to receive us. Having explained the anti-popish character of the doctrines of the Churches of England and of Scotland as well as of other Protestant denominations, and having referred at some length to the original prosperity and subsequent decline and persecution of the Church of Egypt, we expressed our deep regret at the obscuration of their light, our sympathy for their past and present sufferings, and our earnest concern for their restoration to more than primitive excellence. The Patriarch admitted that many grievous errors had formerly crept in; that much deadness still continued to benumb, and much darkness to overshadow them; and that there was need for the infusion of new life and new light. When, in making this admission, he pointedly referred to the sufferings of their martyred fathers, he seemed greatly moved, and melted into tears. What then was to be done towards a revival and a re-illumination? Might not, it was asked, might not the Bible be freely circulated, not in the Coptic, which was a dead language studied by fow, but in the Arabic, which, read by numbers, was understood and spoken by all? Without qualification or reserve the Patriarch declared that it might; adding, with emphasis, that whatever else might be alleged against his Church, this at least had never ceased to be one of its distinguishing characteristics, viz., that the Bible should be 
held as the ultimate standard of appeal in articles of faith ; and that to it, through any intelligible medium, the laity and the priest should, all alike, have the right of unrestricted access. Again, it was asked whether, in order to aid in reviving and diffusing a knowledge of Christian doctrine, tracts or small books in the form of extracts or selections from the most celebrated fathers of the Alexandrian school, who are still regarded with profoundest veneration by the Copts themselves, might not be compiled, translated, and distributed among the people, or introduced into seminaries of education? Without hesitation the Patriarch-smiling with evident delight at our respectful recognition of names which have reflected honour on the Christian Church-replied, that there could be no possible objection to such a measure, yea, that he would consider such tracts and books an invaluablo boon. The subject of raising or rather new-creating a standard of instruction for the clergy next occupied the main part of conversation. Not to arouse the fears and suspicions of an ignorance so profound, not to tear up by the roots a plant so sapless and feeble by sudden stretches of innovation, it was asked in the first instance, whether a seminary might not be established in which candidates for the ministry could pass through a systematic course of theological tuition, making the Bible itself the great text-book, and selections from the most venerated of the fathers important auxiliaries, superadding, with a view to the expansion of the mind by an enlargement of the range of ideas, a course of instruction in geography and general history, ancient and modern, placing the whole system under the patronage and supervision of a committee composed of the Patriarch himself and other leading members of the Coptic community, together with the English missionaries, and entrusting 
the latter with the entire practical and professorial duties of the proposed institution? After much initial explanation, the Patriarch eventually signified his own acquiescence in some such scheme. He accordingly announced his consent and sanction that Mr. Lieder should forthwith prepare in writing a well digested syllabus of the projected plan, to be submitted formally to himself and his council of bishops and presbyters for their united approval and ratification; and that, when approved of and ratified, an authenticated copy thereof, signed by the Patriarch and sealed with the patriarchal signet, should be furnished to the missionaries, to be by them forwarded for the satisfaction of the British Churches, with a view to secure and guarantee their countenance and support. After replying to many other questions relative to the present doctrines, discipline and ceremonial of his Church; and after thanking us for the interest which had been manifested in its re-invigoration and prosperity, the Patriarch rose up and solemnly pronounced his benediction, subjoining, with tearful eyes and quivering lips which betrayed deep emotion, the simple but devout aspiration: 'If we should never meet again in time, my prayer is, that we may meet in heaven, before the throne of our common Lord and Saviour." "

For the expedition from Cairo to the peninsula of Sinai a party of five English gentlemen offered to join Dr. Duff. At Alexandria he had engaged an assistant at the British Consulate, who was master of the popular Arabic. The sheikh of the tribes of the Sinai range, happening to be in Cairo, was secured as guide of the caravan, Mr. Lieder making the necessary contract. Each of the six travellers had three camels, for himself, for the tent and for the provisions. One was a Madras civilian, whose ideas of comfort in 
the desert proved to be those of the most luxurious nawab that Theodore Hook or Thackeray ever satirised. The route was the most southerly, from old Memphis to Jebel Attaka, believed by the scholars of that day to have been the line of the Exodus, just as the latest scholar, Brugsch Bey," would now send the Israelites north through the Serbonian bog. Before sunrise on the morning after the first encampment in the desert, when all were up for a frugal breakfast and early start, the nawab was heard shouting for his gridiron, and then for chops. He was pacified with difficulty, but only to call an early halt for ' tiffin,' or luncheon, in the blazing sun. Next day a sandstorm threatened to engulf the whole party, and the unhappy gourmand demanded to be led back to the joys of the Waghorn hotel in Cairo. He was forced to proceed, but his troubles were not yet at an end. On the following morning, after the misery of the sand, he called for water. Dr. Duff's description of the scene used to be most amusing. "For what purpose?" "Why," said the nawab, " to have a bath, for this state of things is simply intolerable." His associates tried to persuade him that it was vain to expect water for such a purpose. Then it was that he coolly asked for one or more of the hogskins in which water for culinary purposes was carried, though, as the skins had not been sufficiently tanned, the water by that time had got the colour of London porter! Yet being the only water available for necessary uses, no part of it could be given up for the luxury of a bath. The civilian was still unsatisfied, and could not be quieted. At last it occurred to some one to call the sheikh. The look of the Arab was one of perfect

* A Bistory of Egypt under the Pharaohs derived entirely from the Monuments. By Henrs Bragsch Bey. 1879. 
astonishment. He eyed the Sybarite from head to foot as if his eyes would penetrate his very body. At last when the explanation was fully given, the sheikh, instead of a formal reply, looked somewhat contemptuously at the gentleman, put both bis hands down into the deep sand, took up a handful, rubbed his fingers with it, and looking steadfastly at the Englishman, said with great emphasis: "That, sir, is the water of the desert!" The result was that, from Suez, Dr. Duff alone went on to Sinai, while his companions returned to Cairo, not however without having exacted from the sheikh a new pledge, drawn up by the English vice-consul then just established at Suez, to bring back in safety the foolbardy missionary !

The silence of the desert of Sinai for the next fortnight proved a time of refreshing to the spirit of the solitary traveller, as he passed from the toils of the West to the labours about to be renewed in India. Bible in hand, he rode day by day along the track of the children of Israel, as they had marched, noting the wells, the palm-trees, the acacias, the camel tracks, and the desert landscape. As he left the Red Sea for the great plain at the foot of the Mount of the Law, he followed the eastern central route and returned by the south-western, that he might cover as much ground as possible. It was evening when he came to the outer border of the great platform of the wilderness of sandy rock. The rays of the setting sun fell slantingly on the stupendous masses of grey granite which form the Sinai range, as it stretches for forty or fifty miles along the sea and rises to a height of between 8,000 and 9,000 feet. To his imagination the sight was that of a mighty fortress on fire, of blazing battlements and flashing towers. On the morrow at sunrise, while the ground was still bound by frost, the disintegrated granite seemed a mass of orient pearl and gold, and 
the plain looked as if strewed with the manna from heaven, which melted away as the sun rose in the sky. Since that time many a scientific explorer and, finally, the Ordnance Survey have revealed the physical appearances of the wilderness of the wanderings, only to leave the question of the actual peak from which God talked with Moses as unsettled as ever. Dr. Duff's experiences, as often told to his children and grandchildren down to his last years, have an interest of their own.

The broad valley running along the north side, opposite the eastern portion of the Sinai range, is the Wady es-Sheikh. The wady runs eastward for some distance, then turning to the south it enters the centre of the great range, and proceeds westward to the foot of Jebel Musa, the traditional Mount Sinai.* 'This undoubtedly, Dr. Duff used to say, is the route that would be pursued by any great caravan or large company of travellers, and more particularly by such a host as that of Israel. From the central point in the Wady es-Sheikh there is a pass which rises on the right to a considerable elevation, and runs straight to Jebel Musa. Following this, Dr. Duff was struck by the appearance of the precipitous mountains on both sides. It really looked as if the mount some time or other had been cleft asunder. As he ascended, the mountain air became exhilarating in a way scarcely to be conceived. When the summit of the pass was reached, a lofty, perpendicular conicallooking mountain suddenly rose up some miles in front. Immediately the whole of the Arabs dismounted and began to shout out, "Jebel Musa,"

Dean Stanley's map of the traditional Sinai, in his Sinai and Palestine (1860), best illustrates Dr. Duff's experience in 1840, and Dr. Wilson's in 1843 . 
"Jebel Musa," "Jebel Musa," showing the veneration they had for the mountain. Then the traveller entered on a very remarkable gently sloping plain, the slope being downwards to the foot of the mountain, but the surface as smooth as if it had been artificially prepared. Here was a plain quite capable of holding the entire encampment of the Israelites, for it should never be forgotten that their ordinary tentage must have occupied very little space, somewhat like that of the Arabs now. This plain seemed a gigantic nest in the centre of the mountains, for all round on every side it was bordered by craggy precipices. The solitude was profound, reminding him of the perfect stillness of a well-kept Scottish Sabbatb. Proceeding onwards he reached the base of a high peak. Here the first thing which astonished him was the literal truth of the Scripture passage which speaks of the mountain that might be touched, and, when the law was given with such awful solemnity from its summit, declares how means were used to prevent the people from touching it. As a native of the Grampians, he had been wont from infancy to gaze at and climb mountains. Then when he read this in the Bible about Mount Sinai, he wondered what it meant; for if any one had told him, as a youth, of any Scottish or Grampian mountain that it might bo touched, or that means might be taken to prevent its being touched, he would at once have inquired-for instance of Schehallion, Ben Larvers, or Ben-y-gloe"Where is the beginning of the mountain?" Now when he saw Mount Sinai itself, the literal truth of the whole description flashed upon him.

A mile or two up the wady, on the east side of the mountain, is the celebrated convent, Justinian's St. Catharine. $\mathrm{He}$ had left Suez on Monday morning, and it was Saturday forenoon when he reached the 
convent. The stately building is an irregular fortress, with apparently no entrance into it. For the sake of protection from the Arabs it is surrounded by a massive wall, forty feet high. In the centre of the eastern wall was a cupola, with a windlass inside; the ordinary rule was, when strangers appeared there, to let down a bag to receive any communication from parties known to the superior, who might accredit their character and position. When Dr. Duff left Cairo there were six who intended to visit the convent, and they got from the Greek Patriarch the requisite order. But here was only one traveller. The superior demanded an explanation from the sheikh. On that Dr. Duff was hoisted up into the convent, and was fairly installed as a guest in all that is left of what was once the great episcopal city of Paran, and a mountain of Greek hermitages to which pilgrims flocked from all parts of the Christian East.

How to communicate intelligibly with the superior and the monks was the Indian missionary's first diffculty. They were ignorant of Latin, but their first evening service, followed by a reading of the Gospels, suggested to Dr. Duff that he should try Greek. After he had been taken round the traditional sights of the convent, including the legendary site of the burning bush, he visited the superior, who was walking on the terrace. Having heard of the convent garden, every inch of the soil of which had been carried from Egypt on camel-back, Dr. Duff said to him, "You have a garden," using the word paradeisos. To him, examining the little spot, the superior said, "You are going to India," as the Patriarch's certificate stated. "Yes," said Dr. Duff, "I am returning to it." "Do you speak the Indian language, then?" "In India," Dr. Duff replied, "there are many languages." On this the superior sent for a monk who had spent 
several years in India, and the man came into his presence exclaiming, "Bahout, bahout salaam, Saheb." The familiar Hindostaree thenceforth became his medium of communication. The old monk was a Russian by birth. As a pedlar he had worked his way through the great Khanates of Central Asia and Afghanistan to the Punjâb, and thence had gone as far as Calcutta, where he had resided for some time. Such wanderings are still not unusual on the part of semi-Eastern races at a low stage of civilization like the Russians, and of our own hardy Muhammadan and Sikh merchants. Sikhs and Hindoos of Western India have been settled in St. Petersburg; there are traces of them in the marts along the Danube, and we have met them in recent years at the Nijni Novgorod fair on the Volga. Not long ago the Government of India was sorely puzzled to find heirs in the Punjâb for the enormous fortune left by a villager who had thus found his way to wealth in the Nerski Prospekt.

Having set his heart on climbing to the top of the Mount of Moses before the sun rose on the coming Sabbath, Dr. Duff persuaded his new friend, in spite of all dissuasions, to call him in time and give him a younger guide with food that he might there spend the day of rest and worship. Excited by the prospect he could not sleep, any more than Tischendorf when, four years after this, that scholar spent Whitsun morn on the peak of Jebel Musa, during the memorable visit when his casual discovery of forty-three leaves of the Septuagint among the waste paper intended for the oven of the convent, led to his discovery of the only complete Uncial MS. of the Bible. Descending from St. Catharine, which the Ordnance Survey places at an elevation of 5,020 feet, while Jebel Musa rises to 7,359 , the impetuous missionary mounted upwards with a speed that alarmed his guide. The 
summit was reached just before the sun's first rays heralded his approach, always rapid in the south, and the sky was clear without a cloud. Dr. Duff's heart was filled with gratitude to God for the favour with which $\mathrm{He}$ had thus visited him. While the monk vainly displayed the contents of his wallet, the traveller was gazing at the first red ray of light which shot and then streamed over the whole range, turning its peaks for the moment into a succession of glowing furnaces. Then rose the glorious luminary of day in all the fulness of its majesty, calling out from the dark waste of mountains the infinite variety of tints and colours. There he penned this letter to his daughter, one of twelve which he wrote to dear friends in Scotland from the same spot:-

\section{"Top of Mount SinaI,}

"Sabbath Morning, 12th January, 1840.

"Mr Dearest $\mathrm{R}-$ - - Did you ever expect to get a letter from papa dated 'Mount Sinai'?-a letter written on the very top of that extraordinary mountain on which Jehovah once came down, amid thunderings and lightnings, so that the thousands of Israel were affrighted, and Moses himself exceedingly quaked! And yet so it is. Here I am on a Sabbath morning, on the 12th January, about sunrise-when perhaps you and your sister and brothers are scarcely out of bed. And amid all the wonders of that most indescribable scene around me I have not forgotten my dear children, or the guardian friends that surround them. Yes, this very moment I have finished reading aloud the 19th and 20th chapters of Exodus,-but oh in what a different voice from that in which they were uttered upwards of three thousand years ago; and liave just now risen from the naked granite peak, on which I knelt to implore the Lord for a blessing-to 
pray that the law might be my schoolmaster to bring me to Christ; and in my prayer, rest assured that you and sister, brothers and other friends, were not forgotten. No; the remembrance of you all has been sweet to me. May the Lord lead and guide you, in grace and in truth, to know and to do His holy will!

"I left Cairo in company with some gentlemen for Sinai. We followed the route of the children of Israel as recorded in Exodus, through Succoth, Etham, Pihahiroth to the Red Sea-to the memorable spot where Jehovah divided the waters of the great deep to afford a safe passage to His chosen people. We could not cross on dry ground, so we travelled northward to Suez, where my companions, from fatigue or faint-heartedness in traversing the desert, resolved to proceed no farther. So, in the society of an Arab sheikh, or chief of a tribe, and a few Arabs, with camels, etc., I advanced alone along the eastern border of the Red Sea into the 'great and terrible wilderness ;' passed the bitter fountain of Marah-whose waters I tasted and found as bitter and undrinkable as ever; passed Elim, where there are still wells and palm. trees; came to the spot where the Israelites next encamped by the sea shore, and so on to the base and top of Sinai, where I now am.

"But you may say, "What, papa, climb a mountain on Sabbath !' Yes, my dear; think for a moment. In Edinburgh, where there is a church, it would be wrong not to go there to worship with the rest of God's people. But here there is no church-no church within hundreds of miles, in which I could worship. Now you know that God is 'not confined to temples made with hands.' $\mathrm{He}$ is a Spirit, and is to be worshipped in spirit and in truth. $\mathrm{He}$ is everywhere to be found, and may everywhere be worshipped. Our 
Saviour often went apart to a mountain to pray; so this morning I retired to the summit of Sinai to hold communion with my God, and to remember in prayer those that are dear to me. I never had such a church before; for this is the church where Jehovah Himself proclaimed the law to the thousands of Israel. And the very rocks now surround me that quaked and shook at that mighty voice. $\mathrm{Oh}$ may we all find refuge from the thunders of Sinai beneath the shadow of the Cross of Calvary!

"This is a solemn spot! This is a solemn day! And never in my life did I before read the fourth commandment with such peculiar emotion! 'Remember the Sabbath-day to keep it holy.' I hope, my dear children, that you strive to obey this and other commands of the Lord. Attend submissively to the instructions of those who are over you; pray that God Himself, by His Spirit, may make you more able to obey. - . Your affectionate papa,

\section{"Alexander Doff."}

Several times during that memorable day did Dr. Duff read aloud, amid the awful silence of the mount, the Ten Commandments. To him the desolation and the barrenness around marked the blighting influences of sin, the hopeless state of man under the law which condemns. In desire he turned to the mount in Jerusalem where the great Sacrifice for sin was offered, and heaven was opened for the Pentecostal effusion which is yet to bless the whole earth. "The law was given by Moses, but grace and truth came by Jesus Christ," the words he had first joined the monks of St. Catharine in reading, rang in his ears as his guide took him to the legendary spots where since Justinian's days it had been taught that Jehovah passed by revealing the skirts of His glory, while farther on the 
Arabs show the footprint of Muhammad's dromedary on the night-journey from Mecca to Jerusalem. Like every traveller before and since, down to the purely scientific members of the Ordnance Survey, Dr. Duff returned from his fortnight's study of the natural features of the peninsula of Sinai strengthened in his conviction of the truth of Holy Scripture. He was invigorated by the air of the desert at that season. His only mishap was his being thrown from a camel and stunned for a time.

The little Bombay steamer arrived at Suez the morning after his return, with the news, then as now eagerly looked for, of the progress of an evil policy in Afghanistan. Sir John Keane had marched up the Bolan Pass to the capture of Kandahar and Ghuznee, where the young lieutenant of Engineers who had forced the gate was his old companion, Durand. But till he learned this Dr. Duff had doubted whether there might be a British India to go to, so fatal did the policy which sacrificed Dost Muhammad seem to all, save to the council of Lord Auckland, and the Cabinet in which Lord Palmerston was the foreign secretary and Sir J. C. Hobhouse president of the Board of Control. But there was a practical question of more importance for the moment-how to secure a passage. Dr. Duff happened to be the first to meet the purser, who advised him to go to the office at once and pay his money. This the missionary refused to do because the day was the Sabbath. Had not the purser respected his conscientiousness, and himself secretly become responsible for the passage-money, Dr. and Mrs. Duff would have been left in Egypt for another month. "I have secured for you the best cabin," said the purser, "next to that occupied by the Commanderin-Chief."

When early in February, 1840, the Suez steamer 
entered the harbour of Bombay, Dr. Wilson was waiting to receive Dr. and Mrs. Duff, whom he at once installed in what was then the centre of all his operations, the mission-house of Ambrolie. The two missionaries to Western and Eastern India, from the Scottish border and the Grampian highlands, from the Universities of Edinburgh and St. Andrews respectively, met for the first time. Robert Nesbit, too, was there, and Dr. Murray Mitchell who had not long before arrived from Aberdeen. All were still young men : Wilson was just thirty-six, and Duff was nearly thirtyfour years of age. Their experience of India had not been the same, for they had been separated by distance, by race, by language, and even by social differences more widely than France from Russia. Like a bracing wind from the north, Dr. Duff brought with him all the news of national and ecclesiastical affairs in Scotland, - of the widening gap in the Kirk, of the work of Chalmers and the toil of Welsh, of the derotion of Gordon and, on the other side, of the kindly zeal of Brunton; of the coming men like Guthrie and Candlish, some of whom he had vainly summoned to higher work in the East; of the missionary spirit of presbyteries and congregations all over Scotland, soon to be checked for a time by internal disruption, but only to burst forth in home and colonial and educational movements as well as foreign missions, along the lines first marked out, as Dr. Chalmers had said, by Duff himself. Nor was the talk only of Scotland, for the Calcutta missionary had visited Bombay to consult about that new mission from the Presbyterian Church of Ireland to which he had given a mighty impetus after Wilson had invited it to the Krishna-desolated lands of Kathiawar.

Dr. Duff embodied his month's experience of Bombay and Poona in a long letter which his Church 
published as a complete narrative of travel. The pamphlet of thirty-six pages forms an artistic picture of Western India, its physical aspects, its varied races, its different civilizations existing harmoniously side by side under the shadow of the Christian Government, its proselytising and other benevolent agencies, and especially its Scottish mission and missionaries. The report, written as he doubled Cape Comorin on the way to Madras and Calcutta, has a peculiar value from the contrast which it suggests rather than works out between the conditions of Western and Eastern India as fields for the agencies of Christian philanthropy. The reproach is often too well founded that, amid the vastness and variety of India and its peoples, the foreign resident becomes so enamoured of his own presidency or province as to do injustice to the others of which he is more ignorant. Hence the conflicting statements and opposing evidence of officials and settlers who have been twenty years in India and speak " the language." Like even the greatest philosophers, they are wrong only in what they deny, while more or less right in what they assert. Of this weakness there is little trace in Dr. Duff's report. He was too well travelled, too scrupulously fair for that. A quarter of a century after his visit we found his representations proportionately true as between the natives of the more imperial and superstitious Bengal and those of the less caste-bound and more commercial Bombay.

In Western India the small community of Parsees, free from caste and aggressive in their progress as having been long oppressed, formed a more remarkable element of the population in 1840 than, since the commercial development caused by the United States civil war, has since been, relatively, the case. The settlement of the land revenue in leases directly be- 
tween the Bombay Government and the cultivator, and the lapse of rent-free tenures, did not foster the creation of such a body of zemindars, or great and generally absentee landed proprietors, as those who crowd native Calcutta. The temporary nature of the Bombay tenure has further proved fatal to the growth of prosperity and of thrift, and has developed the shocking agrarian demoralisation revealed by the Deccan Riots Commission. Had the land revenue settlement of Bombay only been made permanent with the cultivators, it would have created prosperous and loyal millions of peasant proprietors, able to withstand famine, free to attend to and value education and Christianity, and enabled in time to yield in indirect taxation far more than the periodically increased landtax which now keeps them on the margin of starration. On the other hand, the mistake was made in Lower Bengal of applying the financially sound and equitable principle of permanence of tenure not to the cultivators but to their lords, some hereditary and some mere taxcollectors, from whose exactions moreover they were not protected till 1859 , when it was too late to alter society. The knowledge of the revenue officials of India has never been equal to their benerolence. Hence, for want of a Von Stein, the British Government, with the best intentions, has created and is periodically intensifying the only serious danger to the stability of its rule and to the self-developing growth of civilization. This did not escape Dr. Duff's eye when he wrote of the main bulk of the inhabitants of Bombay, the Hindoos:- "As the ryotwaree system prevails-that which regards the ryot, the actual cultivator of the soil, as having a possessory right therein, and as directly amenable to all the fiscal and other regulations of Government-there is no large and powerful body of landed proprietors, corresponding to the zemindars 
of Bengal. From these and other causes united, there is a very marked difference indeed in the outward temporal circumstances of Hindoo society in Bombay and in Calcutta. Most of the arenues to worldly eminence being blocked up or preoccupied by enterprising strangers, and most of the impellant motives to great secular exertion being cut off, the Hindoo community of Bombay seems stricken with a languor and apathy, a poverty and mediocrity, a diminutive weight and influence, a want of general activity or zeal for improvement, which form a perfect contrast to the wealth, and power, and splendour, the liveliness, and energy, and restless spirit of temporal amelioration, which characterize the great Hindoo merchants, bankers, zemindars, and rajas of Calcutta." Since that was written, trade and cotton manufacture have attracted the acute intellect of the Maratha Brahmans and the keen capital-hunting scent of the Goojarat Jains. But this is still true, to some extent, of the effect produced on public instruction by such conditions. Dr. Duff is describing his visit to the Government Elphinstone College and schools :-

"In the schools there are at present about 500 pupils; in the college about a dozen. In passing through the different classes it was impossible not to be struck with the sparkling intelligence in the countenances of the youth. Yet none of the more advanced have begun to exhibit that freedom from prejudice, and that fearlessness of inquiry, which, ten years ago, youth of somewhat the same standing largely manifested in Calcutta. What are the canses of the difference? Some of these may be latent; others are obvions enough. First, the desire for a superior English education is of later growth at Bombay than at Calcutta; and even now it is not so ardent and widely diffused in the former as in the latter. The local government has not done nearly so much to create and encourage the desire as that of Bengal. Besides, one grand stimulus was wanting in the west, which operated with great potency in 
the east. In the west, Persian, the language of diplomacy, was not, as in the east, also the language of the civil and criminal courts-the vernacular tongue being from the first adopted. In the east it gradually became obvious to all thinking minds that an anomaly so preposterous as the administration of justice through a medium alike foreign to rulers and ruled could not, in the nature of things, be long perpetuated. It seemed the demand of reason that the language of one or other of the parties concerned should be substituted. In either case -Persian ceasing to be the language of polite literature and of converse in cultivated society-English must take its place. Hence it was that a strong sense of self-interest, operating on shrewd forecasting minds, gave an early impulse to the study of English in Calcutta, which, in like intensity, could not be experienced at Bombay. Accordingly, while in the latter place the aggregate number, in seminaries of every description, receiving anything really entitled to the name of a good English education, scarcely amounts to a thousand; in Calcutta it exceeds five or six times that sum, though the population at the ntmost is not more than double. But at Bombay, as elsewhere, the English tide has now fairly set in; and nought can arrest its progress till it overflow the land. Secondly, from the more recent and limited character of evangelistic, educational, and other operations at Bombay, it is at least ten years behind Calcutta as regards the general. relaxation of unthinking bigotry, the general tendency of indurated hereditary prejudices towards a state of fusion and incandescence, and the consequent general preparedness for change. Nursed and nurtured in a state of society so uncongenial to mental freedom of inquiry, the young men naturally present a more hostile front of resistance to the direct influences of the new truths offered for their acceptance. This, however, is a cause the force of which will be yearly diminishing. Thirdly, in the Bombay Government seminaries, a preponderant share of attention has hitherto been bestowed on the polite, the mathematical, and the physical sciences, to the comparative disparagement and neglect of the mental, moral, and economic. Now, the former, addressing, as they chiefly do, the imagination, the memory, the understanding or 'faculty judging by sense,' and the speculative reason, are not calculated to produce the same varied influeutial practical convic. 
tions, or to awaken the same bold and stirring activities of inquiry, as the latter; whose very objects are the powers and capacities of the immaterial soul, as well as the duties, rights, privileges and relationships of man, viewed as a member of human society and a denizen of the moral universe. A more vigorous graft, therefore, of the latter on the Bombay Government institutions, would be a decided improvement. Still, as it is in the hundred metropolitan institutions, the noblest, most fruitful, and most enduring of all sciences would be wantingand that is ' knowledge of Jesus Christ and Him crucified.' Until it be admitted, for the sanctifier and regulator of all other knowledge, man's life is, after all, treated practically as nothing better than a meaningless riddle; and bis destiny as nothing higher than that of the "brutes that perish."

The Church of Scotland's Mission, in both Bombay and Poona, was suffering under the combined triumph and alarm caused by the conversion of the first two Parsees who had accepted Christianity. "The Parsee convulsion, like the shock of a moral rolcano, has more or less affected every province of missionary labour. It has laid an arrest on the friendly intercourse which began to subsist between the members of the mission and many of the more influential of the native community. It drove into alienation and desertion the young men educated in Gorernment seminaries, who had been induced to attend Dr. Wilson's former weekly lecture, and Messrs. Nesbit and Mitchell's private erening classes. It greatly affected the attendance on the services in the vernacular languages. It broke up certain departments in connection with female educaticn. It almost anni-hilated, for a time, the English Institution-reducing at once the number of pupils from two hundred and sixty to fifty - and removing the whole of the Parsee youth, by far the most advanced and promising of the number. Yet, in the midst of all these depressing and disheartening calamities, did our brethren betray 
either faint-heartedness or despondency? No! 'Strong in the Lord, and in the power of His might,' they still prayed, and laboured, and persevered."

Very precious were the sympathy and the counsel of Dr. Duff at this time. Of Nesbit, his old St. Andrews companion, he wrote, "With commanding talents of an intensive rather than discursive character, there is no subject on which he is led to concentrate his powers. which he is not sure to master in a style of surpassing superiority. Hence, as a philosophical linguist and practical Marathee scholar, he is generally allowed to be unrivalled." After descriptions of Dr. Wilson's scholarship, the fruits of which he enjoyed in the study of the Cave Temples, and of his influence in society, native and European, Dr. Duff thus testified to his wisdom in the battle for toleration: "Dr. Wilson, who took the lead in the whole proceedings, conducted himself throughout with a manliness of Christian energy which must for ever endear him to all sincere friends of the missionary enterprise." How the great Bombay missionary valued this visit he has told in a remarkable letter of the 28th February, 1840.* Of Panwel, where they parted in apostolic fashion, after reading the 20th chapter of the Book of the Acts and prayer, he wrote: "My memory will often visit the hallowed spot whence we moved asunder." These were the closing words of Dr. Duff's report on Bombay and Poona:-

"Intensely occupied were the days which I spent at both-in visiting educational and other institutions; in witnessing miscellaneous missionary operations; in eliciting all manner of information which might present to my own mind something like a topographical chart of the existing state of things; in addressing, lectur-

- The Life of John Wilson, D.D., F.R.S. (1878), p. 283. 
ing, and preaching; in holding converse with my brethren, individually and collectively: in freely canvassing, reviewing, and comparing all past proceedings connected with the Mission, at home and abroad; in frankly soliciting and communicating suggestions as to the future. Sweet and pleasant was the personal intercourse with my respected brethren; very sweet and very pleasant is the remembrance of it now. Dearly beloved before for their works' sake, they are now dearer than ever, from the felt experience of their worth. We met and we parted of one spirit and of one mind; not merely as children of the same Father. redeemed through the same blood, and partakers of the same inheritance of grace; but of one spirit and of one mind as regards the essential principles, modes, and prospects of missionary operation in India."

The only communication between the western capital and the metropolis of India then was by teak-built sailing vessels round the peninsula. Dr. and Mrs. Duff were the only passengers. Now, Mr. W. Mackinnon has called into existence the second largest fleet of steamers, which carry the traveller rapidly and touch at every port on the wide-stretching coasts of Southern Asia and Eastern Africa, from Singapore and the Java islands reaching to Australasia, along the shores of India, Persia and Arabia to Zanzibar. Hugging the picturesque coast of Malabar, the ship passed native town and feudal castle, pirate stronghold and busy harbour, till, leaving Goa to the north, it dropped anchor for a day and night at Mangalore in the Canara county of Madras. This once dreaded roadstead of Hyder Ali, scene of alternate Portuguese intolerance and Mussulman ferocity, of General Matthews's victory and of the East India Company's treaty with Tippoo, had been occupied by the selfdenying Basel missionaries in 1834. It has been over 
since their greatest as it was their earliest Christian settlement, having now some 1,200 church members out of the more than 6,000 gathered in at other stations. In Hebich, the afterwards famous and somewhat eccentric German then stationed there, Dr. Duff found a friend of kindred spirituality and earnestness. With him and his colleagues the Scottish missionary spent the night in delightful converse * till within an hour of the dawn. Frequently afterwards did Samuel Hebich recall the talk of that night, $f$ especially to the many sepoy officers and civilians of the East India Company, whom his fearless appeals and holy self-denial led to Christ. Mr. Finlay Anderson, the assistant collector who received the Basel brethren in 1834, still survives to help in every good work for the people of India. This was Hebich's last year in Mangalore, where he had laid the spiritual foundation of the Tooloo church, and left among others Dr. Moegling, to civilize not only the Canarese but the recently annexed Coorgs from Mercara as a centre.

Cape Comorin-too low to be seen save where the Western Ghauts abruptly end some miles inland-and Ceylon were then successively rounded, when the ship came to anchor in the swell of the Madras Roads for five days. These days were busily spent in an inspection of the Mission, and in stirring addresses to both natives and Europeans. Mr. Anderson and Mr. Johnston, fruit of the General Assembly address of

- So, long after, Dr. Norman Macleod inspected the allied German Mission at Calicnt, and recorded the "vers encouraging results" of which he wrote: "These, being connected with education as well as preaching, are the more likely to be permanent!"

'The German Memoir of Hebich, of which an English transla. lation appeared in 1876 , contains no reference to this meeting with Dr. Duff. 
1835, had organized out of the St. Andrew's schoul, opened by the Scotch chaplains in Madras in that year, the nucleus of what has since become the great Christian College of South India, representing all the evangelical missions there. Just three years before, on the 3rd April, 1837, Mr. Anderson had begun the new Institution in a hired house in Armenian street, with fifty-nine Hindoo youths. His early success, in the baptism of highly educated Hindoos who became missionaries to their countrymen, had, as at Calcutta in 1830 , and Bombay in 1839, so alarmed the native community as to produce this remark, "Some of our best youths have been forcibly carried off or withdrawn against their will." Yet, when on Monday, the 20th April, Dr. Duff visited the infant college, this was his impression :- "It was wise on the part of Mr. Anderson and his coadjutor to make the Bible itself-as in Bombay and Calcutta - not only the principal book of the Institution, but to bestow upon the teaching of it the largest measure of their time and attention, so long as this could be done without occasioning that desertion of pupils which the more successful prosecution of general literature and science in other native seminaries must inevitably insure, if there be not a correspondent progress in such studies in the Mission seminaries. And certainly in the Bible department, which las been chiefly cultivated, there is much, very much, to excite admiration, delight and thanksgiving to God. Nowhere have I met with young men of the same age and standing who evinced a more intelligent grasp, a more feeling comprehension, of the divine truths which they had learned from God's holy oracles. In some cases, there is every reason to believe that vital and saving impressions bave begun to be made. And even should all be renounced in a day, what has been done will not, cannot be lost. Talk and dream 
who will of not being able, directly and formally, and in the home sense, to preach the gospel in our Indian mission seminaries, I do most solemnly aver for myself, that never, never, when addressing an audience of fellow-Christians in my native land, had I a more sensible consciousness of reaching the understanding and the heart than I experienced when pouring out my soul on the theme of man's lost and ruined state by sin, and of man's redemption through a crucified but Divine Redeemer, in presence of the assembled youth of the General Assembly's Institution, Madras." On the other side, we have this official record by Mr. Anderson of the visit of the founder of the Scottish missionary system in the East: "He left an impression behind him on the minds of our youths which nothing will ever efface. It was quite thrilling to see how he set them on fire by the truths which he exhibited to them in touching and graphic figures, with an energy of manner altogether his own. Their bright eyes seemed to say, as they sparkled with delight, "This man loves the natives, especially native boys." "

Dr. Duff had been delayed on his outward tour too long for himself, if not for the work he had to do. $\mathrm{He}$ reached the pilot ground at the mouth of the Hooghly at very nearly the same advanced season as on the occasion of his first arrival in Bengal. Again did the rotary storm seem to defy his advance. The suspicious calm of a hot May evening, following a lurid sunset, warned the captain to be ready. Before midnight the cyclone burst upon the ship with savage fury. Lashing themselves to the cuddy hatch, the captain and his officers sat ready to cut down the mast should the vessel drift to the shore. For twelve hours the whirlwind raged, with a violence which was set off by a hideous and sometimes ludicrous contrast. An officer who had joined the ship at Madras, whither he 
had returned from leave in the colonies, and who soon after fell one of the thirteen thousand butchered amid the snows of the Khoord Kabul pass, had an Australian parrot which he had diligently taught. Ever and anon in the pauses of the blast, and continuously as if contending with it, the bird was heard to shriek, now defiantly, now pathetically, "There's nae luck aboot the house whan our gudeman's awa'!" The Malabar teak of the Bombay-built vessel withstood the wind and the waves, and the course of the cyclone finally drove it out to comparative safety in the open sea. After a voyage from Bombay of nearly seven weeks, Dr. and Mrs. Duff were received under the hospitable roof of the nephew of Dr. Patrick Macfarlan, of Greenock, who was chief magistrate of Calcutta. 


\title{
CHAPTER XTV.
}

\author{
1841 . \\ FIGHTING THE GOVERNOR-GENERAL.
}

Indis Sacrificed to Party Politics.-Malcolm, M. Elphinstone and Lord Heytesbnry.-The First and the Second Lord Anckland.The Misses Fden.-Controversy between Orientalists and Anglicists Renewed.-Lord Anckland's Minute.-Mr. Marshnan's Comment.-Dr. Duff's three Letters to the Governor-General.-The Irony of Truth.-Lord W. Bentinck and Lord Auckland Compared.-The Missionary and the Governor-General ContrastedVernacular Education by a School Cess urged.-Lord Auckland Arraigned at the Bar of Universal Reason.-The Dangers of purely Secular Edncation denonnced by a Government Serretary. -The Educational Reaction temporarily forgotten in the Cabal Disasters.

LORD AdCKLAND had been Governor-General for four years when, for the second time, Dr. Duff landed at Calcutta. Apart from contemporary history, his appointment to the most responsible office under the British Crown forms the most scandalous instance of the sacrifice of the good of the people of India and of the peace of the Empire to the intrigues and the selfseeking of political parties. India is so far outside of, so high above, the level of purely party politics, that it used to be true that its governing and commercial classes left Whig and Tory prejudices behind them. Even the purely British officials who, as GovernorGeneral, governors, and law member of council, owed their appointments to partisan considerations among others, were generally raised by the very elevation of 
their duties to the disinterested and philosophic level which looked only at the good of India. From the high vautage ground of a Governor-General's seat, the purely domestic questions which cause the rise and fall of ministers in England often look petty indeed. It may be accepted as an absolute test which marks off the really able statesmen among the nineteen Governor-Generals from the few whom history despises, that the former in every case acknowledged first their duty to India; the latter, their selfish gratitude to the party which sent them out. Against rulers like Warren Hastings, Lords Wellesley and Hastings, W. Bentinck and Dalhousie, Canning and Mayo, we have to set Cornwallis (the second time), Amberst and Auckland, not to mention the living.

William Eden, a younger son of a Durham baronet, and a barrister who entered political life, was created Baron Auckland for negotiating a treaty of commerce with France. His successor rendered services to the Whig party of a less evident kind, and in 1830 Lord Grey gave him a seat in the Cabinet. When sickness sent Lord W. Bentinck home after an administration of nearly eight years, the Court of Directors would not allow the most brilliant servant they had had since Warren Hastings, to fill the seat which he occupied provisionally, because his honesty had been equal to his ability. They were willing to see the Honble. Mountstuart Elphinstone appointed, but he had had enough of office as Governor of Bombay and he declined the high honour. On this the Tory ministry selected Lord Heytesbury, who drew the usual allowance for outfit, made the indispensable speech about peace at the Albion, and had taken his passage to Calcutta. But just as, under somewhat similar circumstances, George Canning gave place to Lord Amherst, and died Premier of England, so Lord 
Auckland was sent out instead of Lord IIeytesbury. The Melbourne ministry took office in April, 1835, with Byron's friend, Sir John Cam Hoblıouse as President of the Board of Control. Refusing their confidence to the Tory Governor-General designate, the Whig ministry, which was to hold office for six year's and a half, sent out Lord Auckland to the scat which Bentinck had made more illustrious than ever, and for which Metcalfe and Elphinstone were better fitted than even he. In a word, the British Government had once again jobbed the appointment, and the whole empire was to suffer the consequence in the military disasters, the financial losses, and-greater than boththe political consequences in 1857 of the first Afghan war. Sir John Cam Hobhouse, made Lord Broughton for the iniquity, found in Lord Auckland the tool and in Lord Palmerston, then Foreign Secretary, the confederate who enabled that reckless, blinded official to boast of the deepest stain on the page of English history, "It was I that did it."

The best thing that George, the second Lord Auckland, did was to take to Calcutta and Simla with him his two clever sisters, one of whom, Emily, in her journals, not to mention her novels, has left us unconsciously the most vivid picture of the GovernorGeneral's weakness of character. If to her "Up The Country," and the book which more recently followed it, we add Sir John Kaye's picture of the unhappy fainéant pacing the verandas of Government House at night as he brooded over the horrors of the Ghilzai massacre which made him sleepless, we may form some idea of the man who, between Hobhouse at home and Macnaghten by his side, blindly let the empire drift down the dark current of a policy of which he never approved, but which party prevented him from fairly considering and resolutely refusing to carry out. Any- 
thing would have been better than this drifting, but on him was the curse against which the prophet cried in vain.

It was the Governor-General's vacillation-ending, as is generally the case, in weakly following the evilwhich brought Dr. Duff into conflict with Lord Auckland. The missionary had set out to return to Bengal, grateful to his Excellency for the interest which he and the Honble. Misses Eden had shown in the Institution during his absence, by frequent visits and occasional prizes. As a rule the English settlers, and above all the Christian ministers in India, are loyally on the side of the Government there. They are roused to demonstrations against it only by some such departure from principle as Lord Ellenborough's, or evidence of incapacity to understand the gravity of the crisis as Lord Canning's advisers showed in 1857. Up to the disasters of 1842 Lord Auckland-who had been made an earl in reply to the opposition of the Court of Directors and to the universal public opinion which, then as since, condemned his policy-was personally respected for his amiability. His advisers liked a Governor-General whom they could lead; the public appreciated the social attractions of his court. Those who estimated an administration by a higher standard even praised him for legally completing what his predecessor had begun in the Act of November, 1837, which abolished Persian as the language of the courts.

But another question of still greater importance to the people had come down to him. Lord W. Bentinck's Government had, in 1835, decreed that Euglish should be the language of the higher public instructionfinally, as it seemed. Still the formal approval of the Court of Directors had not been communicated. Not only was Lord W. Bentinck out of office, but Dr. Duff was far away, and of their coadjutors, Metcalfe was in 
Agra, while Macaulay and Trevelyan were soon to go. The defeated orientalists saw their opportunity with the new and weak Governor-General. They resolved to get rid of the reform of March, 1835, by a side-blow. Mr. Thoby Prinsep and the Bengal Asiatic Society led the assault. Mr. Colvin, the private secretary, was neutralised or so far talked over as to seem to consent to the undoing of that which he had formerly urged.

From 1836 to 1839 , the renewed controversy between the Orientalists and Anglicists went on in the form of a dispute as to the proportion of public funds to be assigned to each. On the 24th November, 1839, Lord Auckland signed, at Delhi, a minute which is remarkable among Indian state papers for its bad style and worse reasoning. The contrast to Macaulay's and Duff's was painful. The minute professed to be a compromise of a dispute in which there could be no concessions by what was true to what the Government had officially allowed to be false and therefore unworthy of being propagated by the public funds. But the defeated Anglicists were not to be found, save one. Mr. Marshman, though rather a vernacularist, raised his solitary voice against the reaction in the weekly press. The minute itself no sooner appeared in an official blue-book, fifteen months after it had been written, than Dr. Duff criticised it in a series of letters to Lord Auckland which appeared in the Christian Observer. Mr. Marshman, though grateful to the Governor-General for his personal support of vernacular schools; did not spare the weak amiability which had led his Excellency to apply " the spirit of compromise amongst varying opinions" to a controversy over vital principles. The orientalists he described, in 1841, as "a few elderly gentlemen of the ancient regime, who rather dislike the spread of 
knowledge as a dangerous innovation than hail it with generous confidence as the means of national regeneration; who, if compelled by the spirit of the age to sanction education at all, must use every endeavour to restrain it to the absurdities and logomachies of the dark ages. . . When a retrograde movement is made merely to quiet a few superannuated European gentlemen, and extinguish their already expiring murmurs, we confess it passes our comprehension.

What will be gained by their reconciliation, or to what will they be reconciled?"

The evil which the minute had secretly attempted to do was twofold. It reversed the decree of Lord W. Bentinck by restoring the stipends paid to natives to learn Sanscrit and Arabic books which their own learned men neglected where they did not teach them far more effectually in the indigenous 'Toles' or colleges. Thus error was again endowed, while true oriental research was hindered. And the minute finally shelved the plan for the improvement of vernacular schools and teachers which Lord W. Bentinck had appointed Adam to submit. Lord Auckland became the victim of what was afterwards scouted by his successors as the filtration theory-the belief that if only the higher classes are educated with the public money, the millions of the people who contribute that money may be left in their ignorance till the knowledge given to their oppressors filters down to them. Seriously that continued to be the fact, if not the theory of the Government in Bengal, at least, for the thirty years from Lord Auckland's minute to the time when Sir George Campbell was made LieutenantGovernor of the province.

Dr. Duff did well to be angry, for his experience and his foresight anticipated the mistake. Lord Auckland thus became, not only the foe of a righteous 
policy beyond the frontier but the reactionary enemy of the people of India. But for him the vernacular side of the reforms of Duff and Bentinck rould have become a reality long before the present Earl of Derby's despatch of 1859 on the subject issued in the Duke of Argyll's action, through Sir George Campbell in 1870. Happily Lord Auckland was too feeble even to stunt the already vigorous growth of the English side of these reforms. So, taking Wordsworth's lines as his introduction, Dr. Duff thus began the correspondence. The language now reads as fine irony, since a few brief months were to reveal the incapacity of Lord Auckland and his Government, at home and on the spot, with its miserable results. But, early in 1841, Dr. Duff used such language, as the whole press of the time did, in all good faith and loyalty. Had not Baron Auckland just been made an earl for his apparent success?

" Oh ! for the coming of that glorious time

When, prizing knowledge as her noblest wealth

And best protection, this imperial realm, While she exacts allegiance, shall admit An obligation on her part to teach Them who are born to serve ber and obey;

Binding berself by statute to secure For all the children whom her soil maintains, The rudiments of letters; and to inform The mind with morcl and religions truth."

"Mr LoRd,-When the Governor-General of India has recorded his sentiments on a great national question, and when these have been rapturously responded to by so many of the councillors, the judges, the secretaries, and the leaders of public opinion, it may be deemed presumptuous in a Christian missionary to lift up his voice at all; more especially shonld that voice, however feeble, seem to mingle as a note of discord amid the fresh full gale of popular applause. And so it would be, were the question exclusively one of mere worldly policy. But when it is found to be one which, in its essential bearings, concerns the souls fully as much as the bodies of men, affect- 
ing the interests of eternity not less than those of time, the Christian missionary must not, dares not be silent, even if his voice should be uplifted against kings and governors and all earthly potentates. When the honour and glory of his Divine Master and the imperishable destinies of man are involved, the ambassador of Jesus can brook no dalliance with mere human greatuess, or rank, or power. In the spirit of St. Basil, in the presence of the Roman prefect, be is ever ready to exclaim:- In all other things you will find us the most mild, the most accommodating among men; we carefully guard against the least appearance of haughtiness, even towards the obscurest citizen, still more so with respect to those who are invested with sovereign authority; but the moment that the cause of God is concerned we despise everything.'

"In the influence of policy and arms, you are, my lord, at this moment, the first man in Asia. Speak but the word for peace or for war, and that word will speedily cause itself to be felt from Ceylon to Bokhara, from the Euphrates to the Kianko. Thus planted on an eminence which would make most men giddy, it is no small achievement to have so maintained the equilibrium and balance of the mental powers, that, amid the blaze of conquest and the echoes of victory, you could have paused to indite a calm dispassionate dissertation on educational economics. But does it follow that the first man in Asia, in policy and arms, must also be the first in the department of intellectual and moral husbandry? This may be; but all the probabilities are against it.

"That the author of the immortal work on "The Conduct of the Human Understanding' should be the author of the equally immortal 'Thoughts on Education,' is nothing strange. The intellectual habit from which the former proceeded formed the best possible discipline and preparation for the production of the latter. But that the intellectual babit from which resulted the celebrated Simla ukase on British policy in Central Asia should prove the best discipline and preparation for inditing a Delhi minute on national edacation, would be passing strange. Who that has studied the human mind, or attended to the lessons of past experience, could reasonably expect Lord Auckland to be equally at homeequally great-in both? When the first statesman in Asia steps aside from his own towering eminence to grapple with a 
theme that is wholly foreign to, and incompatible with, his general habits, he must reckon it no disparagement if of him it be recorded, as of Newton and of Brown in similar circumstances, that he has gone out as another man! Still, as the Commentary on Daniel will be perused becauso it is the product of the author of the 'Priucipia,' and the poem of the 'Paradise of Coquettes' will be read because it clains the same paternity as the lectures on 'The Philosoplyy of the Hnman Mind,' so will the Delhi minute on native education obtain currency and favour becanse it is the offspring of a politician and statesman who is at the head of the most powerful empire in $\Lambda$ sia. And as, in the cases of Newton and of Brown, the splendour of their great, their immortal works, is apt, from the blending of association, to shed and diffuse a portion of their own lustre over the kindred but inferior progeny of the same minds; so will the dazzling renown of the present Governor-General of India, as a statesman, be sure illusively to communicate a share of its own brilliancy to a production which otherwise might soon have sunk into oblivion;-a production which is remarkable chiefly for itc omissions and commissions-remarkable for its concession. and its compromises-remarkable, above all, for its education without religion, its plans without a providence, its ethics without a God!"

Having reviewed the whole controversy in Lord W. Bentinck's time, very much in the tone of his "New Era of the English Language," Dr. Duff comes to this conclusion in his first letter :-

"Here are two systems of education, directly opposed to each other, and absolutely contradictory in their entire substance, scope and ends. Reviewing these two systems, Lord W. Bentinck, with the straightforward bearing of British manliness and British courage in the spirit which fired the old barons of Runnymede, and with the decisive energy of uncompromising principle, thus pronounced his decision: ' Regardless of the idle clamours of interested partisanship, and fearless of all consequences, let us resolve at once to repudiate altogether what is demonstrably injurious, because demonstrably false, and let us cleave to and exclusively promote that which in 
demonstrably beneficial, because demonstrably true.' Reviewing the very same system, my Lord Auckland, with what looks very like the tortuous bearing of Machiavellian policy, in the spirit of shrinking timidity which heretofore hath compromised the success of the best laid schemes, and with the Proteus-like facility of temporizing expediency, thus enunciates his contrary verdict: 'Fearful of offending any party, wishing to please all, and anxious to purchase peace at any price, let $\mathrm{ns}$,-dropping all minor distinctions between old and new, good and bad, right and wrong.- - let ns at once resolve to embrace and patronize both, and both alike:-

'Tros Tyriusve mihi nullo discrimine habetur.'

“In a word, 'Let us,' says Lord W. Bentinck, ' disendow error and endow only truth.' 'Let us,' replies Lord Auckland, ' re-endow error, and continue the endowment of truth too.' A decision so wholly at variance with every maxim of truth and righteousness, a decision so utterly repugnant to the progressive spirit of the age, what valid plea, what plausible grounds can be adduced to justify? Justify! It surely must scorn all justification as impossible, and any attempt at justification as the most ludicrous farce. But seeing that vindication is impracticable, does it not admit of some palliatives? If palliatives there be, they may be summed up in a single sentence; viz., that it was most kind and amiable to soothe the expiring sorrows of the superannuated remnant of the race of orientalists, who, like the owls and the bats, have such a special affection for the dingy and the dismal edifices of hoar antiquity, and who, like these lovers of darkness, are ever ready to break forth into strains as doleful as the notes of a funeral dirge, when the crazy crevices in which they have so long nestled are threatened with extermination! Most kind and amiable we admit all this to be! But, beyond this admission, where are we to look for grounds of palliation?

"These words are penned in the full assurance that with your lordship and councillors they will not have the weight of a feather. So let it be. Here, your lordship is everything. Here, politically and civilly speaking, your vorce is all but omnipotent. Speak but the word, and thousands are ready to shout, 'It is the voice of a god!' Speak but the word, and thousands more are ready to fall down and worship whatever 
idol or image you may be pleased to set op. Here, on the other hand, the humble missionary, in a worldly sense, neither is, nor desires to be, anything. Let him but speak the word, and lo, it is the voice of a fanatic! Let him but give forth his warnings, and lo, they are treated with supercilious scorn or branded as a grand impertinence. But, my lord, I must remind you that the greater the power, the more tremendous the responsibility! I must also remind you that-apart from the solemnities of the great assize to which the noble and the mighty will be summoned, without respect of persons, along with the poorest and the meanest of the land-there is, even here below, another tribunal, of a different frame and texture from that of an Asiatic time-serving, favour-seeking community, at whose bar the appeal of a gospel minister will be heard as promptly as that of the noblest lord. There is a British public, and above all, a religious public in Great Britain, which heretofore hath been moved, and may readily be moved again, by the addresses and expostulations of a Christian missionary. It was the righteous agitation of this public which wrenched asunder the bars of prohibition to the free ingress of Bibles and heralds of salvation into India. It was the righteous agitation of this public which accelerated and insured the abolition of the murderous rite of suttee. It was the righteous agitation of this public which foredoomed the nltimate severance of official British connection with the mosques and temples and idolatrous observances of this benighted people. And rest assured, my lord, that as certainly as the rising sun chases away the darkness of night, so certainly will the righteons agitation of this same British public eventually wipe away, as a blot and disgrace, from our national statute book, that fatal act, by which your lordship has restored the Government patronage and support to the shrines and sanctuaries of Hindoo and Muhammadan learning with all their idolatrons, pantheistic and antichristian errors! A surer prospect of earning the garland of victory no Christian missionary conld possibly desire, than the opportunity of boldly confronting, on a theme like this, the mightiest of our state functionaries, in the presence of a promiscuous audience of British-born free-men, in any city or district, from Cornwall to Shetland. His march would be that of one continued conquest. The might and the majesty of a great people, awakened 
to discern the truth and import of things as they are, would increasingly swell his train. And, from the triumph of indomitable principle in Britain would emanate, as in times past, an influence which would soon cause itself to be felt in the supreme councils of India, and thence extend, with renovating efficacy, through all its anti-religious schools and colleges."

In the second letter, with consummate art as well as fairness Dr. Duff takes out of the minute and holds up to eulogy all of it that he can justly praise. Especially does he thank the Governor-General for at last carrying out his own recommendation of 1834, to promote true oriental scholarship by "a separate grant for the publication of works of interest in the ancient literature of the country, to be disbursed through the appropriate channel of the Asiatic Society." He corrects the mistake which would build the pyramid of national education on its apex, beginning with the college, going on afterwards to the secondary school, and leaving the millions without primary schools. He tells what John Knox and his associates did for Scotland in 1560. He urges that the same means which the Scottish Parliament then decreed be adopted by the Indian Government, in levying a school cess on the land-tax, as a road cess had even then begun to be raised. "So might a permanent education fund be established, proportionate to the wealth and population of each province, by 'the surrender in return of one per cent. of the revenue on the part of the revenue receivers for educational purposes.' Well might such a sum, or one hundredth part of their immense revenue, be pronounced the very minimum amount that Indiasunk, depressed, benighted India-has a right to expect or demand from her rulers for securing one main ingredient of the panacea of her intellectual, moral and social maladies." Such a cess was raised first in Bombay, and then by the late Earl of Kellie in a district 
of Central India, till now it is exacted all over India. But it is not the revenue receivers who pay it. Rather have cesses of all kinds, of which that for schools is the least, been added to the periodically increased land-tax,* till the burden of the long-suffering culti- . vators is greater than they can bear.

The third letter arraigned Lord Auckland and his advisers at the bar of universal reason, as spiritually guilty in their education schemes "of what looks like treason against the majesty and sovereignty of the God of providence; of the cruelest wrong to the souls and immortal destinies of thousands" of their Indian fellow-subjects. After a very practical exposition of the fact, ever since pressed upon the Government of India in vain, that it stands alone of all the world in the suicidal attempt to support by public taxation an official system of education which jealously excludes religion of every kind and the sanctions of morality, Dr. Duff thus closed : "For the substantial justice of the charge I appeal-not to the religious public of Great Britain alone-but to the recorded verdicts of the Russells of England, the Cousins of France, the Falcks of Holland, the Altensteins of Germany and all the greatest and most celebrated statesmen of ancient and modern times!"

The appeal remained unheeded by the Government till 1854. The concession then solemnly made by the present Lord Halifax and by Lord Dalhousie, to the

* In theory, half the net produce of the land is left, on the system of thirty years leases, to the cultivators. Year by year cesses have been imposed, till the State takes sixty per cent. and the peasant receives only forty. The latest impost is that of a cess to bo "solemnly," "religiously," set apart as a reserve for the famines which the periodical increase of the land-tax provokes. This new hurden has no sooner been paid for the first time than it has been used to carry on the second Afghan wor. 
effect that the State would adopt the English position of giving grants for secular education and retiring from its functions as a direct schoolmaster whenever the public would take its place, has never been carried out. As a commentary on Dr. Duff's appeal in 1841, on the broken pledge which he secured in 1854 from Parliament, on the alarm of Lord Northbrook in 1875, on the censorship of the native press in 1877, and on the annually increasing political as well as moral and spiritual danger of the system, we may cite this extract, made confidentially to one of Lord Auckland's successors in 1872 by the Home Department which is charged with the imperial direction of public instruction in India :-

"That most remarkable feature in Indian education, the religious neutrality of the Government, is no doubt a relic of the extreme apprehension which prevailed in 1793, and whether its original declaration was a wise one or not is far too deep and many-sided a question to be discussed here. We must accept the fact as we find it. But it is, I believe, absolutely without precedent or parallel elsewhere, besides being entirely opposed to the traditional idea of education current in the East. In Europe, it is almost an axiom that the connection of any State system of education with religion is not the mere result of tradition;* ' it is an indissoluble union, the bonds of' which are principles inseparable from the nature of education.' This is admitted almost universally. Even the French system is religious, not in the sense in which all European systems profess to be more or less so, in inculcating the precepts of a certain universal and indisputable morality, but in inculcating morality in the only way in which the masses of mankind will ever admit it, in its connection with the doctrines of religion. In Holland, primary instruction was decided in a much debated law to be designed to train 'to the exercise of all Christian and social virtues,' while respecting the convictions of dissenters. In Switzerland, religion stands on the same footing

- Public Education, by Sir J. K. Shattleworth, p. 290. 
as reading, writing, grammar and arithmetic, as a fundamental part of the scheme. In Germany, generally, religion still forms, as it has always done, the first and staple subject of the elementary school, and the religion of the master must be in conformity with that of the majority of his pupils. The American system, while repudiating all doctrinal or dogmatio teaching, provides everywhere for the regular daily reading of the Bible and for prajer. And, lastly, the framers of the English Education Act, 1870, have been able to assume as a matter of course that every elementary school would be connected with a recognised religious denomination, and that Government aid might, therefore, be offered to all alike for secular education only. *

"In India, not only is there no religious teaching of any kind in Government schools, but even the aided schools under native managers are generally adopting the same principle. I believe this result was never anticipated, and I am sure it requires attention. Looking to the rapid growth of our educational system, and to the enormous influence for good or evil that a single able and well educated man may exercise in this country; and looking to the dense but inflammable ignorance of the millions around us, it seems a tremendous experiment for the State to undertake, and in some provinces almost monopolise, the direct training of whole generations above their own creed, and above that sense of relation to another world upon which they base all their moral obligations; and the possible evil is obviously growing with the system. It is true that things go smoothly and quietly, but this is attained by ignoring not only the inevitable results of early training on the character and the great needs of human nature, especially in the East, but by also ignoring the responsibility which devolves on the Government that assumes the entire control of direct education at all. If, therefore, while fanaticism is raging around, there is a calm in our schools and colleges, it is an ominous and unnatural calm, of impossible continuance, the calm of the centre of the cyclone.

"The subject is one of extreme difficulty, that grows with the consideration devoted to it. Of course it is out of the question to recede in any degree from the pledges of the past.

- Mr. Gladstone's speech, Hansard, vol. CCII., p. 267. 
And it is probablo that the evil is less serious in primary schools where the instruction given does not necessarily destroy religious belief, whereas our higher instruction does. Therefore, although the State may establish and maintain primary schools where no local effort is forthcoming, it would still seem very desirable that it should retire as rapidly and as completely as practicable from the entire control of all direct instruction, and especially higher instruction, and leavo it to local management to be encouraged by the State, and aided in conformity with the English principle which, without any interference in the religious instruction imparted, practically insures by the constitution of the local boards that some religious instruction is regularly given."

We shall see this vital question coming up again and again to the very close of Dr. Duff's life, when, as he lay a-dying, his memory went back to this conflict with Lord Auckland, and he longed that his life might be spared, if only to fight till he won the battle against a neutrality which is not neutral to but carefully fosters the worst error; against a secularism which is fast robbing the Hindoos even of the natural religion and traditional truth of their own system, till they themselves cry out. The Christian college stands alone in the breach which the rising flood-tide is threatening, while Church and State look on apathetically.

Even the daily newspapers of Calcutta republished Dr. Duff's letters, and.made them the subject of editorial comment. "As no press ever struggled more manfully for its own liberty," he wrote in a note to his reprint of the correspondence, "so none has on the whole ever less abused that liberty when conceded. In this respect the sentence of Sir J. C. Hobhouse must be regarded as downright, though perhaps, in his happy ignorance of Indian affairs, unintentional calumny." But the subject was, in a few months, swallowed up in the snows of Afghanistan, with our 
thirteen thousand troops and their officers. Lord Auckland began his evil policy in July, 1837, with Lord W. Bentinck's hard-earned surplus of a million and a half sterling. He was created an earl in 1840, for that march to Ghuznee which made Sir John Keane a baron though he forgot his battery-train. The more denounced an evil policy is the more fruitful of honours is it expedient for the responsible ministry of the day to make it. Sir J. C. Hobhouse himself became Lord Broughton! In January, 1842, when he had packed his baggage to return home triumphant, Lord Auckland received intelligence of the bloody collapse for which he had converted his great predecessor's surplus into a deficit of two millions, had added enormously to the debt of India, had shaken the English power in the East till it nearly fell in pieces in 1857, had allied his country with iniquity - and yet, had not succeeded in warning his successors forty years after against following in his blood-st.ined feeble footsteps. It fell to Henry Lawrence and George Clerk, to Colin Mackenzie and George Broadfoot, to save the residue of the troops and to rescue the captives alike from the imbecility of the Whig Governor-General and from the madness of his Tory supplanter. 


\section{OHAPTER XV.}

\section{1-1843. \\ THE COLLEGE AND ITS SPIRITUAL FRUIT.}

Outward Sigus of the Progress of a Decade.-The Second Convert a Christian Minister.-The College Bnildings.-The Staff of Five Missionaries.-Their Unity in Variety.-The College Reorganized.-A Normal Training Class.-Dr. Duff's Edacational System then contrasted with the State Colleges now.-The Spiritual Machinery.-The Female Orphanage.-Legal Disabilities and Social Oppression of Hindoo Widows.-The Native Christian Family.-'I'he Death of Dr. Duff's Child in Scotland.Dr. Inglis and his Son, the Lord President.-Sympathy with Mrs Briggs, of St. Andrews.-The Movement in Krishnaghur.A New Vaishnava Sect.-Dr. Duff visits the District twice.-Interview with the Gooroo of the Worshippers of the Creator.-New Stations at Calna and Ghospara.-The Eight New Converts from the College.-Mahendra's First Sermon.-Review of the Twelve.-Proclamation of Peace in Afghanistan and ChinanLord Ellenborough.-Dr. Duff's Anticipations.

When Dr. Duff landed at Calcutta to begin the second period of his work in India, even he was astonished at the outward signs of progress which ten years of English education under really enlightened British administration had brought about. No one could doubt that, in the great cities and intellectual centres at least, as in Italy of the first three centuries, and again of the fourteenth and fifteenth centuries, the Renaissance was a fact. Even on his way from the ship to his own college-building and principal's or senior missionary's residence, which he had yet to see, he passed through a succession of such outward evidences, which he reported in his own graphic style to Dr. Brunton. 
The first object that liad caught his eye on landing was a signboard on which were marked in large characters the words, "Ram Lochun Sen \& Co., Surgeons and Druggists." Not six years had passed since the pseudo-orientalists had declared that no Hindoo would be found to study even the rudiments of the healing art through anatomy. But here, scattered over the native town, were the shops of the earlier sets of duly educated practitioners and apothecaries who had begun to find in medicine a fortune long before the chicane of law attracted them to our courts.

"When I gazed at the humble, yet significant, type and visible symbol before me of so triumphant a conquest over one of the most inveterate of Hindoo prejudices-a conquest issuing in such beneficial practical results-how could I help rejoicing in spirit at the reflection that, under Divine providence, the singular success of your Institution was overruled as one of the main instruments in achieving it? Oh! that a like energy were put forth-an energy like to that which characterized the Divine Physician-for the healing of the spiritual maladies of the millions around us! Holy Spirit! do Thou descend with a Pentecostal effusion of Thy grace. Come from the four winds, $O$ breath, and breathe upon these slain, that they may live. Blessed be God that the better cause is neither wholly neglected, nor without promise.

"After passing the Medical College itself, the next novel object which in point of fact happened to attract my attention as I approached Cornwallis Square, was a handsome Christian church, with its gothic tower and buttresses, and contiguous manse or parsonage. And who was the first ordained pastor thereof? 'The Rev. Krishna Mohun Banerjea, once a Koolin Bralman of the highest caste; then, through the scheme of Government education, an educated atheist and 
editor of the Enquirer newspaper ; next brought to a saving knowledge of the truth as it is in Jesus, and admitted into the Christian Church by baptism, through the unworthy instrumentality of him who now addresses you; and, last of all, ordained as a minister of the everlasting gospel by the Bishop of Calcutta, and now appointed to discharge the evangelical and pastoral duties of the new Christian temple which was erected for himself! What a train of pleasing reflection was the first view of this edifice calculated to awaken! Men there are who, practically ignorant of the real nature of the gospel and of the power of God's grace themselves, still choose to deny the possibility of converting Hindoos of good caste. To repudiate with holy indignation the downright atheism of such denial, it is enough for the believer to know that with God all things are possible. But here was, in addition, a sensible refutation of the atheistic dogma. Here is not a low caste, but a high caste Hindoo, yea, one of the highest order of the Brahmanical caste in India; not an ignorant man, but one who, having gone through an ample course of European literature and science, explored the labyrinth of Hindooism with the torch of modern illumination, and deliberately rejected his ancestral faith as a tissue of absurdity, superstition and cruelty; not a rash enthusiast, but one who, in his ignorance of a better faith, having been led to deny the very being of a God, was persuaded, on the ground of reason and consistency, to examine the claims of natural and revealed religion; one who, having had his understanding opened to discern the resistless force of evidence, and his heart deeply affected by a sense of the suitableness and adaptation of the gospel remedy to his felt condition as a guilty and helpless sinner in the sight of God, publicly and solemnly embraced the 
Christian faith, through the sacred ordinance of baptism. Such has been the steadfastness of his Christian walk and conversation for the last eight years, that even the bitterest enemies among his own countrymen now, with one accord, acknowledge his sincerity. Nor has he been inactive in his Master's service. Naturally endowed with no ordinary degree of energy and force of character, he has laboured assiduously and successfully as a teacher, a catechist, and now an ordained minister of the gospel of salvation. $\mathrm{He}$ preaches regularly both on Sundays and week-days, in Bengalee and in English, to suit the wants of this country, to men who have, or have not, acquired a European education. Nor has he laboured in vain. Through his faithful ministrations not a few have been shaken out of their idolatries. Several educated natives of high promise have professed Christianity; and some already act as his fellow-helpers in advancing the cause of the Redeemer in this benighted land. Who can dare to gainsay facts so notorious and decisive? And do they not amount to a visible demonstration of the wretched fallacy of the atheistic dogma, of the alleged impossibility of converting high caste Hindoos? Shall we glory in being able to appeal to such emplatic demonstration? Never, never! so far as man's instrumentality is concerned. But we glory in the Lord. His is the kingdom, and His the power, and His too-and His alone-must be all the glory! 'It is the doing of the Lord, and marvellous in our eyes.'

"Of the Bengalee sermons preached in this new church the author has published a small volume. They are designed specially for Brahmans and other high caste Hindoos. Both from their style and substance they are admirably calculated for the object designed. Of this work, remarkable as being the first volume of regular sermons ever published in the 
Bengalee language by a Brahman convert and ordained preacher of the gospel, and peculiarly enhanced in our estimation from the circumstance of its author being one of the first-fruits of the Church of Scotland's Mission to India, I shall endeavour, by the first opportunity, to send you a copy. Nor is the illustration hereby afforded of another process of paramount importance to be overlooked. What is wanted to insure, under God, the rapid and extensive spiritual regeneration of India, is not an exotic artificially sustained life, but an indigenous, self-sustaining, selfpropagating life. Here, then, is the process commenced in this great heathen metropolis. One has been called of God, endowed with such gifts of nature and endowments of 'grace, as to have not only life in himself, and for himself, but life so abundantly as to be enabled, through the Divine blessing, to communicate a portion to others around him. These already, in the good providence of God, have been blessed in imparting a share of their own vitality to others; who must be destined to impart the same to others still, in an onward progression, through an ever widening circle. The rate of augmentation, at first gradual and almost imperceptible, may at length advance with a rapidity which might well make the present pioneering generation incredulous. Here there is one case where Christianity may be said to have fairly taken root in the Indian soil, where the process of indigenous selfpropagation may be said to have fairly begun. The poor earthen vessel which had originally been employed, under Providence, in conveying the seed of life to this portion of the Indian soil, after depositing the seed in the spot pre-ordained and chosen of God, became shattered and useless. To prove that it had nought to do with the giving of the increase, the human instrument was wholly withdrawn from the field. By 
his withdrawal was the process of independent selfdiffusion arrested? On the contrary, in the particular instance under review, it progressed more rapidly than ever. And though the original conveyer of the seed had died, or had never returned, the process would have still gone on, to the praise of God's glorious grace. Surely a statement of fact like this might well dart a ray of new light into the darkest caverns of prejudice and unthinking bigotry. Surely it might open up a glimpse of the holy and noble extent and purpose of the most frequently misunderstood part of our labours. For what is the main and leading design of all our Christian schools and missionary colleges? Is it not, in humble dependence on the blessing and fruitful increase of God's Holy Spirit, to raise, and rear up, and multiply a superior race of natives who, like the Rev. Krishna Mohun Banerjea, shall bo privileged to originate and perpetuate the mighty process of gospel propagation through all the cities and provinces of India?

"After passing the new church, which stands out to the eye so pleasing a monument of the incipient progress of Christian influence in this heathen metropolis, I came full in view of the Assembly's new Institution and Mission-house, on the opposite side of Cornwallis Square. Gratifying as some of the preceding spectacles were, this to me was the most gratifying of all. What a change since May, 1830, and how different the thoughts and feelings of the spectator! Then, almost the only thing determined on was, that Calcutta should not be my head-quarters and fixed abode;-now, I saw before me my head-quarters and permanent residence. Then, the precise line of operations to be adopted was not only unknown, but seemed for a while incapable of being discovered, as it stretched away amid the thickening conflict of contending dif- 
ficulties;-now, there stood before me a visible pledge and token that one grand line of operation had long been ascertained, and cleared of innumerable obstacles, and persevered in with a steadfastness of march which looked most promisingly towards the destined goal. Then, I had no commission, but either to hire a room for educational purposes at a low rent, or to erect a bungalow at a cost not exceeding $£ 30$ or $£ 40$; -now, there stood before me a plain and substantial, yet elegant structure, which cost $£ 5,000$ or $£ 6,000$. Then, it was matter of delicate and painful uncertainty whether any respectable natives would attend for the sake of being initiated into a compound course of literary, scientific and Christian instruction; -now, 600 or 700 , pursuing such a course, were ready to hail me with welcome gratulation. Then, the most adranced pupils could only manage to spell English words of two syllables, without comprehending their meaning;-now, the surviving remnant of that class were prepared to stand an examination in general English literature, science and Christian theology, which might reflect credit on many who have studied seven or eight years at one of our Scottish colleges. Then, the whole scheme was not merely ridiculed as chimerical by the worldly-minded; but as unmissionary if not unchristian, in its principles and tendencies, by the pious conductors of other evangelizing measures; -now, the missionaries of all denominations resident in Calcutta, not only approve of the scope, design and texture of the scheme, but have for many years been strenuously and not unsuccessfully attempting to imitate it to the utmost extent of the means at their disposal. Yea, so strong has the conviction of some of them become on the subject, that in some instances, they have laboured to promote the object not only without the sanction, but almost in spite of the declared 
sentiments of the home committees of the parent societies; and, as one of the number (who has devoted the last fifteen years exclusively to Bengalee preaching, but who has gradually become an enthusiastic admirer and advocate of our scheme, as one of the mightiest engines for the dissemination of the gospel in India) again and again declared to me, in the presence of other missionary brethren, the main argument employed by them in writing to, and expostulating with their home committees, has been an appeal to the model, example, and palpable success of our Institution. -Then-not to multiply more contrasting parallelisms, -it was my lot to stand alone, without any actual assistance or practical co-operation whaterer,-alone, yet not alone, for I was driven the more urgently to look to God as my helper and my counsellor, my fortress and my tower;-now, I was to join four beloved brethren, one in spirit, one in mind, one in purpose, one in resolution, able, willing, ready mutually to assist, mutually to co-operate in carrying out the great generic principles of the Mission into their full and legitimate development. In the midst of such a crowding profusion of past remembrances, and present realities, and future prospects, I trust that the presiding feeling after all was gratitude to the Father of mercies, and joy in the God of our salvation. Who am I-did the soul instinctively cry out-who am I, that the Lord should condescend so graciously to visit me? After being in deaths oft, after so many perils by land and water, after so much unprofitableness and unworthiness, who am $I$, that $I$ should have so much given me of my heart's desire? that I should be spared to witness so much of what, ten year's ago, had been pronounced to be the wild dreams of a visionary, actually realized? Almost instinctively was $I$ led to appropriate and apply, in a very humble and 
subordinate sense, the words of aged Simeon:- ' Lord, now lettest Thou Thy servant depart in peace; for mine eyes have seen Thy salvation, which was prepared before the face of all people,-a light to lighten the Gentiles, and the glory of Thy people Israel.'"

If the college building and the mission-house, with their spacious grounds, in a fine open square and yet close to the busiest part of the native city, formed the fruit of his home labours on which he could look with legitimate satisfaction, much more had he reason to rejoice in the colleagues who had followed him, and had so well carried out his plans during his absence. The whole staff, with Dr. Duff again at its head, formed a remarkable group of five pioneers, such as no other mission has probably ever enjoyed at one time. Dr. W. S. Mackay, whom we have previously described, had bravely brought a spirit of intense devotion and unusually high intellectual grace to bear up his frail body, until the arrival of Dr. Ewart soon after Dr. Duff's first departure set him free to obey the physician's order. He had restricted his energy, but in 1838 had been forced to visit Tasmania in search of health. In the Australian colonies he had pled for the Mission with a quiet power which led many of the churches to try to detain him. But declaring that even at the risk of chronic sickness there was no career like that of an Indian missionary, he had returned to his post, shipwrecked like Duff in the Bay of Bengal. Dr. Ewart seemed a man whose physique the tropics could not touch, even when he lectured and taught for six hours a day and rested only to give up his evenings to the increasing inquirers and converts. Mr. Macdonald had found a place peculiarly his own in the purely theological work of evangelizing all the classes, and specially of training the catechumens who sought to be first catechists 
and then ordained missionaries to their countrymen. Youngest of all, and now the only survivor, Dr. T. Smith after a visit to the Cape of Good Hope to throw off the then too fatal dysentery of Bengal, had amply redeemed the promise which Dr. Duff saw in him when presiding at his ordination in St. George's, as a spiritually aggressive missionary to the educated Hindoos and as the first mathematician then in the East. St. Andrew's kirk, too, was a help to the Mission rather than a drag on its energies, as in former days, under the two chaplains, Dr. Charles and Mr. Meiklejohn. Thus generously, but truthfully, did Dr. Duff write home of the colleagues who only needed him among them to consolidate and carry out to still wider results their varied labours.

"Our missionary brethren, Messrs. Mackay, Ewart, Macdonald and Smith, have, in different ways, been labouring up to the full measure of their strength, and some, it is to be feared, beyond their strength. Of the rich and varied endowments and graces which all of these have been privileged to bring to bear upon this great missionary field it is impossible to think, without admiration of the disinterested devotedness wherewith all have been consecrated to the advancement of God's glory ; or, rather, without adoring gratitude towards Him who bestowed the willing heart to regard such self-consecration as one of the chiefest of the privileges of the heirs of glory. How admirable the ordinance of Heaven! Diversities of gifts-yet one spirit! Here there are five of us, born, brought up, educated in different parts of our fatherland, in diverse circumstances and amid indefinitely varying associations. Still, when thrown together, in the inscrutable counsels of Divine providence, in a strange and foreign land, without losing any one of our peculiar idiosyncrasies, we find that we are one in spirit, 
one in the prime actuating motives, one in the grand design and end of our being! Blessed be God for the realization of such oneness and harmony, as the product of a genuine Christian love. With one accord, for reasons a hundred times reiterated, we regard our Mission Institution as the central point of our operations. In the present exigencies of India, it cannot be otherwise in the eye of any largely observant and contemplative mind. From an intelligent conviction of the peculiar character of the present wants of India, as well as from voluntary obligation, we all feel ourselves pledged, systematically, to devote a due proportion of our time to the advancement of the interests of an Institution which has already infused so much of the leaven of divine truth into the vast mass of native society; and which promises, with the Divine blessing, to infuse still more. The remainder of our time is daily devoted to prayer-meetings, conversations, discussions, preaching, translation, preparation of tracts, or any other miscellaneous objects of a missionary character which may present themselves in the course of providence, or which may best comport with the ability or predilection of the individual labourers."

By 1841, too, Dr. Duff's return enabled him to reorganize the Institution in all its departments, rudimentary school and college, English and Oriental. While the ecclesiastical doctrine and practice of Presbyterian parity, of the equality of ordained elders lay and clerical, governed the presbytery and the kirk in all purely spiritual things, organization required something more for the efficient working of a great college and a growing mission. All the gifts and varied energies of the five men must be utilized and directed to the one spiritual end of the immediate conversion of the students, as the test of a system which aimed at far more, even the ultimate subver- 
sion of the whole Brahmanical system and the substi. tution of an indigenous Christian Church. Dr. Duff's earliest act was to propose the formation of a inissionary council to meet regularly for consultation and prayer under the senior, or whomsoever the Church at home might recognise as the senior, on account of peculiar fitness for the presidency of a Christian college. The machinerv thus established within the Presbyterian ecclesiastical system, has ever since worked as well as in any divinity or university Senatus in Scotland. Men who are not only gentlemen, but gentlemen of the highest type-the Christian, will find no difficulty in such cases save when a mistake is made in adding to their number. The odium ecclesiasticum is a sure gauge of the diminution of the love of Christ, not a proof of intelligent earnestness for the truth. For one Athanasius there are a thousand like Paul of Samosata. Certainly, with the exception of the two sacerdotal parties of the Church of Rome and in the Church of England, foreign missions or missionaries have ever testified to the Churches which sent them forth, that in Jesus Christ there is neither party nor sect, that the devil is a common enemy strong enough to require all the unity of the evangelical forces. How Dr. Duff's reorganization of the Mission was received by his colleagues, Dr. Mackay thus officially reported to the committee: "Dr. Duff will tell you of our meeting togetber regularly for consultation, and of what we have agreed on; but I cannot refrain from saying, that in all our new and complicated arrangements, arising out of our increased number and efficiency, there has been no difference of opinion; and we are all agreed as one man. Each is satisfied with his own peculiar work, and all are satisfied that everything has been done for the best. In Christ we feel that we have one Head, one end, and sne mind; and 
believing, we pray that we may always labour together in peace, and unity, and love."

To no subject, when in Scotland, had Dr. Duff devoted more of his little leisure than to the careful inspection of all educational improvements in school and college made during his absence in India. These he now proceeded to adapt to his Bengalee circumstances. He had the buildings, the library, the philosophical apparatus for scientific and technical training-everything but the assistant native teachers. In all India there was not a normal school at that time. The Mission had raised its own subordinate masters, but on no regular system. He saw that his first duty was to devote part of the strength of his increased staff to the systematic training of native schoolmasters. He had introduced the gallery system, as it was called, into India for the first time. Every Saturday the Institution was crowded by visitors to see the novel sight of some three hundred boys from six to twelve exercised after the most approved fashion of David Stow, beginning with gymnastics and closing with an examination on the Bible. Here was his practising department. Daily, since he lived in the grounds, did Dr. Duff himself induce all the native teachers to remain for an hour, when he taught them "Paideutik," with results which soon showed themselves in the increased efficiency of the school. Not only so, but he was continually called on to surrender his best teachers to other Missions and to Government, while he was consoled by the consciousness that he was thus extending a Christian, as well as educational influence, far and wide. 'To utmost Sindh, as it then was, as well as far eastern Burma the college sent forth teachers of other schools, as well as officials for the many subordinate and sometimes higher appointments of the State, so that the little leaven was gradually leavening the whole lump. 
The General Assembly's Institution at that time was strongest in the two allied, though too often divorced subjects, of physical and mental science. The missionaries themselves were fresh from the highest honours in the classes of Chalmers and Jackson, Leslie and J. Forbes, Brown and Wilson. Of the five, four were masters in the field of mathematics, pure and applied. Dr. Duff himself lectured on chemistry, but his special delight lay in the exposition of psychology and ethics, leading up through natural religion to the queenly theology of revelation. A native student of that time,"* who has now been for years a professor in a Government college, bears this testimony to the intellectual and scientific training of a period when "cram" was unknown, when competition had not learned at once to stimulate and to poison the higher education, and when physical science was taught as the handmaid of faith. Dr. Duff lectured on the methods of teaching pursued in Scotland, in Switzerland, in Germany, in Prussia; and expounded the systems of Stow, of Fellenberg, and of Pestalozzi. Two things were greatly insisted on throughout the classes-a clear conception of an idea in the mind, and the expression of that conception in words. "Duff did not think that a boy had thoroughly caught hold of an idea unless he could express it in his own words, however

Rev. Lal Behari Day, professor of English Literature in the Government College, Hooghly. These were the studies of the highest college class, in 1843:-In Theology : the Bible, Scriptural doctrines with textual proofs, Greek Testament, Taylor's "Transmission of Ancient Books," Paley's “ Horæ Paulinæ." In English : Milton's "Paradise Lost," Young, Bacon's Essays and "Novum Organum," Foster's Essays. In Psychology: Brown's Lectures, Whately's Logic and Rhetoric. In Mathematics: analytical geometry, spherical trigonometry, conic sectious, the differential caiculas, optics. In Physics: geology, magnetism, steam navigation. In Sanscrit: the Mngdhaboda. In Persian : the Gulistan and Bostan. 
inelegantly. We therefore took no notes of explanations given by the professors; indeed, no notes were given in the class, under the apprehension that they might contribute to cramming. How just that fear was must appear evident to every one who observes the mischievous consequences arising from the practice of giving notes now adopted in all the Indian colleges. The students of the present day never open their mouths in the class-room-unless, indeed, it is to make a noise. They take down the professor's words, commit them to memory-often without understanding them-and reproduce them in the examination hall. A copying-machine would do the same. Another feature in the educational system pursued in the General Assembly's Institution was the judicious mixture of science with literature. At the present day the cry in India, as in Europe, is-physical science. And many people think it is a new cry. But thirtyfive years ago Duff took his pupils through a course of physical science, in addition to a high literary course. Mechanics, hydrostatics, pneumatics, optics, astronomy, the principles of the steam-engine-the text-books generally being of the science series of Lardner-were taught in the college classes. A course of lectures on chemistry was also delivered, accompanied with experiments; the youthful and fascinating science of geology was studied on account of its bearing on theology; while we were so familiar with the use of the sextant, with Norie's 'Navigation, and with the 'Nautical Almanac,' that some captains of ships, after examining us, declared that some of my class-fellows could guide a ship safely from the Sandheads to Portsmouth. The Bengal colleges of the present day have not yet advanced so far as the General Assembly's Institution did, under the guidance of Duff, thirty-five years ago." 
In all this, however, again as in the solitary time of his founding the Mission, the intellectual was directed above all things, and excluding all other inmediate ends, to the spiritual. A new creation in Christ Jesus was what the founder and the four colleagues of like spirit with himself sought to make every student, while they were sustained by the divinely given consciousness that they were working for ages yet to come, under the only Leader with Whom a thousand years are as one day, against a system which would not fall, as it had not risen, in a night.

So when the reorganization of the college was complete, several directly and exclusively spiritual agencies were called into play. First, the public offices being now shut on the Sabbath-day, Dr. Duff opened a class for the systematic study of the Bible by thoughtful and religiously disposed Bengalees, who had never studied in a Christian college, and were occupied as clerks all the week. Many of that large class were in the habit of visiting him and the other missionaries, as inquirers, in the evening. Every Sunday morning, at seven o'clock, saw a goodly number of young and middleaged Hindoos, of the higher class, gathered in the mission-house during the three years which ended with the disruption of the Kirk. Dr. Wilson was doing similar work in Western India. Never, probably, siuce Pantænus, the first Christian missionary to India, and his successors in the great School of the Catechumens, evangelized the lands of the Mediterranean and the Indian Ocean from Alexandria, had there been such searching of the Scriptures. The result of that three years' work was that the majority of the Hindoo inquirers expressed an intellectual conviction of the truth of Christianity. Only the Spirit of God, in direct, irresistible and expanding influence, was wanting so to touch their hearts as to make them dare the renun. 
ciation of father and mother, caste and kinship, for Christ. "God is a sovereign God," Dr. Duff once said of these busy years, " and at that time, so far as I could judge, the grace of God's Spirit operated effectually on only one soul, to whom it brought home with power the whole truth of gospel salvation through Jesus Christ." We shall come to him and to others, and we shall see in the coming years how the seed bore fruit of different kinds secretly and openly.

For another class, students who had left college for the world but still desired at once the elevating influence of companionship with the missionaries and the continnance of their studies, Dr. Duff opened a weekday evening lecture in his house. There they read, in a critical spirit, those master-pieces of literature in which were most apparent suggestions of good thoughts and spiritual ideas drawing the reader to the higher life. Such were Guizot's History of Civilization,* a history of the Renaissance and Reformation which had gained the prize offered by the French Academy, and John Foster's Essays. This, too, proved most popular. The older men had yet to be cared for, Hindoos who had left college just before or at Dr. Duff's arrival, who remembered the lectures of 1831-4, and desired to renew their investigations. For such he delivered a weekly lecture in a side-room of the Institution, on the leading points of a complete system of mental and moral philosophy, leading up to religion, natural and revealed. Here his remembrance of the famous series of Chalmers at St. Andrews, in which he had been the foremost man, stimulated the missionary.

* The Protestant missionaries in China have just issued the prospectus of fifty-one treatises to be written for the people of China and Japan, by the ablest Sinologues. Dr. Williamson is engaged on a History of Civilization for this Chinese encyclopædia of pure and Christian literature. 
He brought his large audience of thoughtful hearer's to the utmost confines of psychological observation and the ethical reason, and then pointed them to "the bigher calculus of revealed truth."

At this time, too, he saw the first streaks of the dawn of that day which he had anticipated ten years before, when the educated Bengalees would demand educated wives, and the increasing community of native Christians would seek the means of instruction for their children. The orphan refuge for girls, begun by Mrs. Charles, was developed into an efficient Bengalee school under the Ladies' Society, and from that in later days, in its two branches, many young women have gone forth to be zanana teachers, and the happy wives and mothers of a prosperous Christian community. The time for more public and direct aggression on the ignorance and social oppression of the women of Bengal, at least, was not yet. In a noble building planted just opposite.Dr. Duff's first college, and beside the church of his second convert, the Honble. Drinkwater Bethune, a member of the Government, founded a female school, which, though no longer premature, pure secularism has ever since blighted. Yet the two enlightened Brahman landholders of Ooterapara, near Calcutta, had in vain besought the State to join them in opening a school for Bengalee young ladies there.

But while Duff sought, in the new orphanage, to prepare Christian teachers, wives and mothers for the future, as it developed before his own eyes, he was no less active in procuring the removal of legislative obstructions to the freedom of women within legitimate limits. In an official letter of 16 th September, 1842, he expounded in detail the two evils of infunt betrothal and early marriage-before puberty, often-and of tho prohibition of widow marriage. The characteristic disbelief of Hindooism, in common with all systems except 
Christianity, in the continence of man and the purity of woman, makes widows for life of the infant girls whose betrothed have died. These, growing up despised, ill-treated and overworked, become the centre of the household and village intrigues which fill the records of the criminal courts of India, and the mainstay of the thousand great shrines to which pilgrimages are made from vast distances and amid incredible bardships all over the peninsula. Weary of life and dissatisfied with herself, allowed a freedom unknown to the wife and frequently never herself a wife, the Hindoo widow vainly seeks peace at the hands of the touting priest, who strips her of her all-even of what honour she may have left-in the name of the Vaishnava deity. Or she courts rest at the bottom of the village well. Add to this the state of wives who are no wives, of the Koolin Brahman's hundreds of wives, some of them whole families of mother and daughters, and we have an idea of the moral and spiritual problems which Christian education faced in even orthodox Hindoos. With satisfaction did Dr. Duff observe the discussion of these in the vernacular newspapers, and the formation, so early as 1842, of "a secret society among the educated Hindoos for privately instructing their young daughters and other female relatives."

On the other side he had, before this, described his administration of the ordinance of Christian baptism to the first boy of his third convert, Gopeenath Nundi: "The Christian Hindoo father stood forth, in the presence of his countrymen, some of whom had formerly been either his pupils or companions, holding in his arms the infant whom he desired solemnly to consecrate to his God and Saviour. Beside him stood the Christian Hindoo mother, holding by the right hand her firstborn, a little girl of three 
years. And there, in the presence of God and man, did both parents unite in taking upon themselves the most sacred vors and obligations to bring up their little one in the nurture and admonition of the Lord." Thus, in the heart of the Brahmanism of Bengal, there was growing up the sweet plant of the Christian family. And the agitation against the legal prohibition of widow marriage, begun in these years, bore its fruit in the Act of Lord Dalhousie and Sir Barnes Peacock, whicb, just before the Mutiny, removed all legal obstructions to the marriage of Hindoo widows.

While thus sowing joy for generations to come, Dr. and Mrs. Duff were called to bear the bitterness worse than death-the sudden blow of the removal of one of their own children far away from themselves. Long separation and frequent death form the oft-repeated tragedy of Anglo-Indian life. That is none the less bitter that it occurs so often, and seems all the more cruel that the dearest friends who have never left home can only balf sympathise with the sufferers. Duff's impulsive, continuously impetuous affection rushed forth to all his friends and converts, but it flowed in a rapid and deep stream towards his family. In Dr. Brunton he had made a friend to whom he poured forth all the fulness of his heart in private letters, often side by side with his official correspondence. Thus did they write each other, and thus did Dr. Duff, in his own sorrow, comfort the venerable and still surviving lady, Mrs. Briggs, of St. Andrews, whose gift he employed in the mission work :-

"Edinburgh College, 2nd June, 1841.

“Mr Dear Dr. Dofr, - I had counted upon commencing my letter by this mail with an appeal which would, I well know, be readily responded to, for your sympathy and condolence under our sore bereavement. But, in the unsearchable counsels of God, I am called, on the other hand, to offer ours to you. 
Our heavenly Father has called little Anne to Himself. I need not detail the circumstances. I know that more than one affectionate friend intends to transwit them to you. Nor do I need to remind you what are the duties to which, after the first sore burst of anguish, you will feel yourself called. I write merely to assure you that the little sufferer had every human resource which yon yourself could have desired. Mrs. Campbell watched her with maternal care. The best medical skill of Edinburgh was promptly and affectionately bestowed on her. We have laid her in Dr. Inglis's burial place, close to the spot of his own ballowed rest.

"I will mix up no other theme with this. The little which I had to say on business I address to Mr. Ewart. I am sure you will not misunderstand me, as if $I$ imagined that, even under this sore trial, you would cease for a day to labour in your Master's work. On the contrary, I know by experience that such labour is most wholesome medicine in human sorrow. But you are well entitled to judge for yourself at what precise time and in what proportion you are best able to bear the medicine. Mr. Webster happened to be here from Aberdeen on Assembly duty; and nothing could exceed his devotedness in doing all that was kind and useful. He has written to you, I believe; as has also Dr. Abercrombie. Miss Stevenson (the writer's niece) communicates with Mrs. Duff by this despatch. My dear friend, my prayers and my best wishes are with you. May God Himself sustain and cheer you! Yours affectionately, "Alexander Brunton."

"Calcutta, Cornwallis Square, 17th August, 1841.

"Mr Dear Dr. Bronton,-How strikingly did the mournful intelligence by the last overland make me realize the force of the humble but expressive adage, ' a friend in need is a friend indeed.' Often, often, have I in retrospect watched with wonder and delight the manifold acts of personal kindness shown to me by yourself and Miss Stevenson. And I assure you that, unable, in the deep sincerity of my heart, to find anything in myself worthy of such kindnesses, I have been ever led to ascribe it all to the special grace and favour of God my heavenly Father, who hath been pleased in His sovereign mercy to raise up unto me friends in so peculiar a sense. But oh, methinks your last attentions to our darling and beloved child 
were, if possible, the kindest acts of all, attentions paid too amid your own sore, sore domestic bereavements. It were to affect a stoicism alien to my nature were $I$ to pretend that the affliction has been to us a light one. Oh no, it was one of the heaviest that could possibly have befallen. Even now, after the interval of nearly a month, the vivid realization of it brought about by my writing this note scarcely allows me to proceed. The tears flow now as copiously as on the day of the unexpected intelligence. But do not, my dear father and friend in the Lord, do not conclude that these are tears of murmuring or complaint against the will and act of my heavenly Father. Oh no, they are the meltings of the poor weak human heart of a fond parent, still smarting under the rod of my heavenly Father's chastisement. I can truly say that if these past weeks have been fertile in natural sorrow, they have also been still more fertile in spiritual joy. Every thought of my departed darling child is associated with the thought of heaven-the home of the weary pilgrim of Zion, and the remembrance of Him who hath gone before to prepare mansions of glory for all His faithful followers. I have felt more in the communion of the Divine Redeemer and its fellowship with the redeemed in glory, than I have experienced for some time past. Still may I say, it was good for me to have been thus afticted.

"It was a kind thought of yours, and in beautiful harmony with all your other refined and delicate consideration for human feelings, to have our little one laid beside the man for whose memory beyond all others I cherish the deepest veneration. Kindest and best thanks to dear Mrs. Inglis and family for their ready consent. Also my warmest thanks to the committee for their tribute of respect. I think far more of their act of favour in behalf of the departed than if they had bestowed thousands on the living. May the Lord reward you all.

"The enclosed business note for Dr. Gordon I leave open, that you may peruse its contents, and lend your aid in accelerating the object solicited. Before this reach you, the Madras events will have cheered you. $W e$ have reason to bless God and take courage. It is not to be expected that Satan will surrender this long-possessed realm withont a deadly struggle. Your report to the Assembly has been very soothing and cheering : may the Lord bless its diffusion. The enclused you will kindly hand over to Mr. Inglis; it also contains ons 
for his mother, Mrs. Dr. Inglis. This reminds me of what I often intended to ask; could you not manage to procnre for us a bust (or even a print, if that cannot be had) of Dr. Inglis, to be set up in the library of our Institution? Surely nothing could be more appropriate. With heartfelt thanks and remembrances to Miss Stevenson, Mrs. Stevenson, and love to my dear young friends the Borrowmans, I an ever gratefully and affectionately,

"Alexander Dufr."

\section{"16th November, 1841 .}

"My Dear Mrs. Briggs,-It was indeed kind of you-more than kind-amid your own affliction and sore bereavement, to remember one so distant and so unworthy. The announcement of the death of your dear husband I had noticed, and louged to learn some particulars relative to his latter end. This I was disposed to ask for as a favour at your own hands. But you more than anticipated me. And your doing so, unsolicited and unprompted, enhances the favour a hundred-fold. That you had 'much comfort in his death, which was that of the Christian enjoying peace in believing ;'-ah, my friend, these simple bnt touching and thrilling words in your letter did cause tears of joy to flow from eyes which, in these heathen climes, seldom find matter but for tears of sorrow, and a song of grateful thanks to ascend to the Father of spirits from a heart which, though vexed daily and almost hardened by the freezing obduracy of the votaries of idolatry, has not yet (blessed be God) wholly lost its sensibilities or its sympathies with the great Christian brotherhood. To sleep in Jesus, to die in the Lord, oh, is not this the top and flower of all other blessings here below? What more could the expanded souls of the ransomed in glory, what more could the burning desires of a seraph long for on behalf of sinful mortal man, than that he should fall asleep in Jesus? This being the case with your departed husband, while, if I met you, I could not help weeping along with you, could not help the outgush of nature's tenderness and nature's regrets, I should also soon be constrained to mingle joy with my weeping on account of the ascended and ransomed spirit. And in order to die the death of the righteous, oh, may it be ours to live the life of the righteous, to be united to Christ by a living faith, to be grafted on Him as a living branch, to be built up in Him as a 
living stone, to be replenished, through the energy and inworking of His Almighty Spirit, with that grace now which shall ripen into glory hereafter. These, my dearly beloved friend, these are amongst the blessings which constitute the heritage and possession of God's own children.

"As to your remembering me by the large munificence of a Christian heart, as well as the kinduess of a Christian's holiest wishes, I know not what to say. Coming from one whose noble and (considering the arduous circumstances of the case), I will add, heroic example of piety I was wont to admire and gather strength from when yet a feeble neophyte myself, I cannot doubt the heartfelt kindliness of the motive, and dare not therefore refuse. In the spirit of Christian love that prompted the token of remembrance, I cannot but accept it as sent to me by the Lord, through the instrumentality of one of His own chosen ones. And I pray God that I may be privileged to employ it in such way as may best promote His own glory and honour. Recompense you on earth I cannot; I can only pray that the God of all grace may continue to shower upon you still richer effusions of His fatherly loving-kindness, and in the world to come reward you a hundred-fold. And to all your other kindnesses, oh, deny me not the crowning one, to remember me in your daily petitions at a throne of grace, that the Lord may uphold $m e$ in His strength, and cause His pleasure more abundantly to prosper in my unworthy hands.

"Amid much to humble we have much to cheer us here. The other day we joyously admitted a young Brahman, of whose faith in the atoning sacrifice of the Divine Redeemer we had ample evidence, into the communion of Christ's visible Church. But as Dr. Brunton will probably publish some portion of the account I sent him, I need say no more here. Is Miss Grace still with you? Often, often, do I blend my being with ten thousand recollections of St. Andrews. There I passed some of my earlier days of sin and folly, and shameful neglect of God and salvation. There, too, the Lord was pleased to rescue me as a brand from the burning. Oh, praised be His Holy Name. Were I to name the many men in whom I feel the deepest interest, and to whom I would beg to be remembered, my whole paper would be filled. The Lord bless you, and enrich you, and ennoble you more and more by the shining of His grace. Yours gratefully and affectionately,

"Alexander Dufr." 
In the year 1838, when Dr. Duff was in the press of his home operations, the news came from Nuddea, a county fifty miles to the north of Calcutta, of large additions of Hindoo and Muhammadan peasants to the Church. In 1830 he had visited the spot, among other parts of rural Bengal, only to decide that he must begin the Scottish Mission in Calcutta, and from that as a base extend his influence. In 1832 the Church Missionary Society opened a school in Krishnaghur, the county town, and baptized five students in the first twelve months. By 1838, whole villages with their head men had sought instruction, and hundreds of earnest men and women, under purely spiritual influences, were baptized, and proved their sincerity by suffering persecution unmoved. Then there came into operation motives of a more mixed character. The river Jellinghi, one of three streams into which the mighty Ganges spills over so as to form the united Hooghly on which Calcutta stands, inundated the district and swept off the rice harvest. The result was a local famine, from too much water, such as we have twice witnessed since that year. There was no railway to pour in food as now, no machinery to link the million of sufferers with the charity of Great Britain, no prudent anticipation on the part of the authorities. The work of relief fell, as usual, on the few missionaries, English and German, who sailed over the inundated plains of an area as large as Lincolnshire, distributing rice to the dying and lending small sums to those who could thus struggle through the crisis. The result was precisely what Madras and Mysore have recently displayed on a greater scale. The evangelization of the previous six years, ${ }^{*}$ acted on by gratitude

- The Trident, the Crescent, and the Cross (1876), by the Rev. James Vaughan, who is now again building up the Church at Krishnaghor amid many difficulties. 
for the humanity and sympathy shown, bore both natural and spiritual fruit in the profession of Christianity by thousands. On one occasion Bishop Wilson presided at the baptism of nine hundred Hindoos and Muhammadans. Dr. Duff drew up a document explaining the movement to the churches at home. Judging from analogy there can be little doubt that Krishnaghur and the rich sugar, indigo, oilseed and jute districts of the Hooghly Delta would by this time have been what the Tinnevelly Church has become, in similar circumstances, had the missionaries not com. paratively deserted it before the infant church had been consolidated and had produced its own tried and trained pastors. As it is, the large nominal Christian descendants of the first converts, among whom caste has crept and the sacerdotalism of Jesuit priests recognising caste, is being again evangelized, like the lapsed sections of our own cities and mining and manufacturing districts.

But there was another providential preparation for the rapid creation of the Krishnaghur Church. When Rammohun Roy was feeling after God, as we have already told, among the learned of Burdwan and Calcutta who knew Sanscrit and English, there was a villager of the cowherd caste in Ghospara, near Krishnaghur, who in the Bengalee vernacular admitted neophytes to a new sect on the payment of a rupee and the recitation of this Muntra, or combined creed and charm-" $O$ sinless Lord. $O$ great Lord, at thy pleasure I go and return; not a moment am I without thee; I am ever with thee. Save, O great Lord." Ramchurn Pal was really a follower of the great reformer Chaitunya, but he set up a new sect which recognised him as the incarnation of Krishna rather than the character which he professed. The Gooroo, or teacher, was the sinless lord, entitled to all the 
spiritual power and offerings. This new sect of Vaishnavas called themselves Kharta-bhajas, or worshippers of the Creator. They ate together twice a year ignoring caste, and gained over many women and infirm persons by the belief that the Muntra removed barrenness and disease. Such is the account of the Gooroo's contemporary, Mr. Ward, of Serampore.* In this its first stage, before the denunciation of caste had given place to free love, as in many such sects, and the cessation of idol-worship had been followed by the substitution of one god for another, the new teaching sent many to swell the ranks of true but uninstructed Christians.

To a careful study of the Kharta-bhajas, with the view of founding a mission among them, Dr. Duff deroted the college vacation of 1840-41, and again of 1841-42. As the guest of the Church missionary, Mr. Alexander, he was at the head-quarters both of the sect and of Christian operations. In discussing vernacular education, helping to spread village schools and frequent meetings with both the Christians and the Kharta-bhajas, two months passed away. He signalized his farewell by a simple feast to the Christians of one station, at which five hundred squatted, oriental fashion, before piles of curry and rice and the fruits of the cold season, spread out on the soft green leaves of the plantain-tree, and deftly conveyed to the mouth with two forefingers and thumb. So the Rishis ate on the ancestral Aryan tableland. But here were also women and children, and glad sounds of praise arose to the God and Father of our Lord and Saviour,

* Vol. ii., page 175, of $A$ View of the History, Literature, and Mythology of the Hindoos (1818, second edition), by W. Ward. A work now of some rarity, and drawn npon by not a few writers without due acknowledgment. 
Jesus Christ. Dr. Duff was intensely human, rejoicing as much in the social feast of the lately christianized families, in its way, as in their solemn acts of puro worship. Desirous to concentrate his mission on the left bank of the river, Mr. Alexander urged his Presbyterian guest to take possession of Culna, opposite, once the great port of fertile Burdwan, and still a pilgrim town of 50,000 inhabitants, where the perpetual lease of a piece of ground had been secured. After inspecting the place, Dr. Duff dropped down the Hooghly to Ghospara, now three miles from the railway station of Kanchrapara. There, in a mango tope or grove, he visited the Gooroo of the Khartabhajas. Surrounded by his disciples, the son of Ramchurn made a statement of his faith to the missionary sitting upon the simple "charpoy" or low couch-bed of the East, and willingly granted him, in perpetuity, a lease of land for a Christian school and church. From the fifty thousand pilgrims who twice a year crowd to the "cold sea" or pool whose waters had healed the wife of their Gooroo, and to the sacred pomegranate-tree under which she was buried,* he thought to gather many to Christ.

But where were the missionaries for the rural stations, thus increased to three-Takee, Culna and Ghospara? In the first, Mr. Clift had been succeeded by Mr. W. C. Fyfe, sent out from Scotland as an educationist and subsequently ordained, so that he is now the senior missionary in Bengal. Happily the college in Calcutta, which, in 1830, had begun with the Lord's Prayer in Bengalee, the English alphabet, and the slow spelling out of the Sermon on the Mount, and had given its first four converts to the Anglican, American Presbyterian and Congregationalist

- A Statistical Account of Bengal (1875), vol. ii., p. 53. 
Churches, because the Kirk was not prepared to utilize them, was producing the ripest spiritual fruit. Established to sway towards Christ, and by Christ, the whole revolution of thought and feeling which the English language and the British administration had set in motion and were hurrying away from all faith and morals, Dr. Duff felt that his college would be an immediate failure if it did not bring in individual souls and raise an indigenous missionary ministry. Before all other agencies for educated Hindoos, his system had, in 1830-1834, accomplished both results. Nor had it ceased to do so in his absence, while his return gave it a new impetus. Whether we look at the spiritual or the intellectual character of the young men; whether we consider what they sacrificed for Christ, or what $\mathrm{He}$ enabled them to become in His work, we may assert that no Christian mission can show such a roll of converts from the subtlest system of a mighty faith and an ancient civilization as $\mathrm{Dr}$. Duff's college in the first thirteen years of its history.

We begin with the one failure-let the truth be told, but tenderly. In 1837, Dwarkanath Bhose, at the age of seventeen, was baptized. No convert witnessed so good a confession as he, if persecution be the test. He was the Peter of the band. Thrice carried off by his bigoted family, chained and imprisoned till Mr. Leith's services in the Supreme Court were necessary to enforce toleration, he clung to his convictions. So bright a student did he become that he was one of the four Bengalees selected by Government to complete their medical studies in London. Was it there that, like not a few of his countrymen since, he found the temptations of a great city, in which he was alone, overpowering ? With the highest professional bonours he returned to practice in Calcutta, where he fell a victim to the vice which our excise system has taught the educated 
natives of India, when it plants the licensed wine-slinp beside the Christian school. We visited him in his fatal sickness. Who shall say that, like Peter also, he did not rise, ever so little, from his fall? It is not English Christians, at least, who can judge him. Rather let us judge our own want of faith and cliarity towalds India; our own administration which, now purged of most other debasing tendencies and immoral monopolies, still uses the whole power of the State to secularise public instruction, and to raise an annually increasing revenue by spreading drink and drug licences far and wide over India and even China. The missionaries were used to make Dwarkanath Bhose the noble convert and accomplished student he was when he landed on our shores-who is responsible for the rest?

A fellow-student of Dwarkanath's would have stood by his side in baptism. Laid low by fever he sent for his companions, declared to them that he believed in Christ, and died before he could be baptized. He was one of a large class of secret Christians, who have been known to baptize each other in the last hour. The bloom of the Mission, intellectually and spiritually, was also cut off by an early death-two converts who lived and worked long enough to become the David and the Jonathan of the Church of India, Mahendra Lal Basak and Kailas Chunder Mookerjea. Mahendra had entered Dr. Duff's school in 1831, at the age of nine, but was removed to the Hindoo College because of the direct Christian teaching of the former. Returning he became so thoughtful as to alarm his Hindoo friends, who tried to seduce him to sins which, they thought, would make even the missionaries shun him. It was in vain. He rose to be the gold medalist of the college, and his demonstrations of some of Euclid's problems were so ingenious as to call forth the eulogy of Professor Wallace, of the University of 
Edinburgh. But his intellectual power was dedicated to the office of the Christian ministry. Baptized in 1839, after renewed opposition from his father, he became the first divinity student of the college. The same year saw him joined by a Koolin Brahman, Kailas, who had gone through the six years' course of the college. When on the way with his family to an idolatrous service, his conscience so pricked him that he fled to the mission-house. Gentle and confiding, he was deluded by solemn pledges into leaving its protection, when he was kept in durance for three months. On escaping he was publicly baptized in the college hall. After systematic theological training, the two friends were appointed catechists. Part of their practical training had been to accompany the missionaries on itineracies through the rural districts in the cold season. Dr. Duff thus described his experience of Mahendra, as a preacher, at the beginning of 1841 :-

"In these rural itineracies I had much reason to be satisfied with the docility, humble demeanour, and moral earnestness of my young friend, Mahendra. His tact, too, and management in meeting the objections, and in presenting divine truth in an intelligible form to the minds of his countrymen, were such as to encourage no ordinary expectations as to the future. On one occasion he displayed much eloquence and power. Standing on the steps in front of a temple of Shiva, in the large town of Culna, we got into a long and varied discussion with the Brahmans. Soon an immense crowd was assembled. They professed their readiness to listen to what the $S a h e b$ had to say; but when, at my suggestion, Mahendra began to ask certain questions, he was at first received with a shout of derisive scorn. 'What!' exclaimed they, 'shall we give ear to the words of a poor ignorant boy?' With the greatest calmness and self-posses- 
sion Mahendra replied, 'Well, friends, if I am a poor" ignorant boy, is that not a stronger reason why you, who aro so learned, should take pity upon me, and give me the knowledge which you believe would remeve my ignorance. I began to ask the questions, not with a view to abuse you, or your faitb, or to display my own learning, which is very little; but simply to know what your creed really is, and thus enable mo to compare it with my own.' 'This 'soft answer' had the desired effect. After answering some questions, they began to interrogate in return. In reply to tho query respecting his faith, Mahendra began by giving a brief sketch of what he was by birth and education, and how he came to renounce Hindooism and embrace Christianity. His exordium at once caught the ear and riveted the attention of every one; and not a whisper was heard from the previously unruly and uproarious audience, when he commenced his narrative by saying, 'Countrymen and friends, I am a Hindoo; I was born and brought up a Hindoo; yea, I belonged to the Boistobs, one of the strictest sects, as you know, among the Hindoos. My father was aud is a Boistob; my mother was and is a Boistob; they were both very careful in training $m e$ up in the knowledge of their peculiar creed; they made me attend upon Radhanath, one of the great pundits of the Boistob sect; at his feet I was brought up; he laboured to imprint upon my mind the doctrines of Atma, Onama, and other Shasters.' How forcibly the preliminary part of this address made me realize the exceeding naturalness and adaptation of the Apostle's appeal, in somewhat similar circurnstances, and with a view to somerhat similar ends! 'Circumcised the eighth day, of the stock of Israel, of the tribe of Benjamin, an Hebrew of the Hebrews; as touching the law, a Pharisee!' How forcibly, too, did it make me feel the superiority of the 
vantage-ground on which a qualified native must ever stand, when addressing his own countrymen-his own kinsmen according to the flesh! Oh that we had hundreds of Mahendras!-hundreds exhibiting similar qualifications of head and heart; then might we begin to lift up our drooping heads, in the full assurance that the day of India's salvation was nigh at hand. At the conclusion of Mahendra's long address we distributed all the tracts in our possession. We had reached the temple about five p.m.; it was now eight o'clock; and the full moon, shining from the deep blue vault of an almost starless though cloudless sky, lighted us back to our small boat on the river. On our way, we overheard many remarks respecting what had been said; amongst others, the following: "Truly, he looked a poor, ignorant boy; but his words showed him to be a great pundit." "

These were the men, Mahendra and Kailas, who were placed in Ghospara as missionaries to their countrymen. Within a few weeks of each other, in the year 1845 they passed away, after services which Dr. Ewart and Mr. Macdonald recorded in Memoirs of them. So, also, the amiable Madub Chunder Basak died ripe for heaven. Dr. Duff longed for hundreds like them, and he did not pray in vain. Passing over the baptism of another Brahman, of Kalichurn Dutt, and of Dr. Duff's converts baptized by other Churches, we come in 1841-3 to the conversion of the four remarkable Hindoos who lived to be ordained ministers of the Free Church of Scotland, and at Culna and other rural stations, as well as Calcutta itself, proved successful missionaries. The Rev. Jugadishwar Bhattacharjya, a Brahman of the Brahmans, above eighteen, whom a mob attempted to tear from the mission-house, has since won the gratitude of his peasant countrymen, alike by his spiritual and his temporal services to 
them, having saved many in the time of famine. Such are his knowledge and influence, that he was selected by Lord Northbrook to give evidence before a Commons committee. The Rev. Prosuuno Koomar Chatterjea, once of the same highest caste, has long presided over another of the rural missions in Bengal. The Rev. Lal Behari Day, a successful English author and Government professor, who preaches regularly to the Scotsmen sent out to superintend the jute mills on the Hooghly, has lately told the world his "Recollections" of the missionary who was one of his spiritual fathers. Last of all, but now no more, do we linger over the name of the Rev. Behari Lal Singh, the Rajpoot who died the only missionary in India of the Presbyterian Church of England. The teaching which led him to sacrifice all for Christ he and his brother received in the college; the example which afterwards proved to him that Christianity was a living power was that of his official superior, Sir Donald M'Leod.

From the converts made up to 1843 we have named these twelve-four in the first period, eight in the second-as the typical fruit of the system directed by the first missionary of the Church of Scotland to the destruction of Brahmanism and the building up of the Church of India by educated Hindoos. The first, Brijonath; the sixth, seventh, and tenth, Mahendra, Kailas, and Madhub, became early fruit of the native Church in heaven, but not before Mahendra and Kailas had done true service for their Master. With a joyful catholicity Dr. Duff had given Krishna Mohun to the Church of England, Gopeenath to the American Presbyterian Church, Anundo to the London Mission, and Behari Lal to the English Presbyterians. Of the twelve not the least brilliant fell; while we shall see Gopeenath witnessing a good confession in his hour of trial in the Mutiny. 
While the college, in spiritual influence and intellectual force, with its 900 students and three branch stations, was thus advancing to the state of efficiency in which it closed for the last time in 1843, all around there were then, as now, disaster and confusion in public affairs. Thus longingly did Dr. Duff dwell on the triumphs of peace, and on the way which it opened for the Prince of peace, into the lands beyond our frontiers, then on the Sutlej and the Yoma mountains of Arakan. How hopefully, in the Punjâb, the Karen country and China, have his anticipations been realized. What he wrote of Lord Ellenborough even may stand, for he wrote it on the 17th October, 1842, before the Somnath Gates proclamation and the Sindh war, Captain Durand being that Governor-General's private secretary :-

"For the last three years all India has been in a state of suppressed ferment and smothered excitement, by the desolating warfare in Afghanistan and China. A permanent peace with Afghanistan may prepare a way of access to the vast nomadic hordes of Central Asia, who, from time immemorial, have been the conquerors and desolators of its fairest and richest provinces. The last few years have served to prove that, though the sword of war may destroy, it cannot tame or subdue any portion of these wild and lawless races. What fresh glory will this shed on the triumphs of the gospel, when, by the peaceful 'sword of the Spirit,' these very tribes are brought into willing subjection, and endowed with meek and lamblike dispositions! A permanent peace with China may open up an effectual door of ingress to more than $300,000,000$ of human beings-one-third of the entire race of mankind !-hitherto shut up, and, as it were, hermetically sealed against the invasion of gospel truth. How mysterious, and yet how wisely beneficent the ways of 
Divine Providence! China being sealed against the direct intrusion of Bible heralds, the last thirty years have been chiefly devoted by the lamented Morrison and others to the study of that unique and solitary lingual genus, the Chinese tongue-to the investigation of Chinese antiquities, literature, mythology, and otber such like subjects as tend to throw light on the genius, the character, the mental and religious habitudes of so singular and multitudinous a people-to the preparation of grammars, and dictionaries, and tracts, and, above all, to the translation of the Word of life, that Book of books, the Bible. And when the requisite apparatus for an effectual spiritual warfare has been fully prepared, suddenly and unexpectedly the immense field for their practical application has been thrown open, by the instrumentality of one who 'meant not so, neither did his heart think so.' (Isa. x. 7.) What a striking coincidence! Who dare say that it is fortuitous? Oh no! It is altogether the ordination of Him who ' knoweth the end from the beginning.' It is one of those marvellous points of confluence among the manifold streams and currents of Providence, which may flow, for years or even ages, unseen beneath the surface, till the 'set time' hath come for their springing forth visibly, to bespeak the presiding presence of Him, who 'doeth according to His will among the armies of heaven and the inhabitants of the earth.'

"If anything could enhance the joy which we have all experienced from the simple announcement ' Peace,' it is the language in which the present GovernorGeneral has couched his solicitation for the offering of public prayers and thanksgivings to Almighty God throughout all the Indian Churches. From the State circular, penned by Lord Ellenborough himself, I extract the following passage:- ' The seasonable supply 
of rain, following our prayers recently offered to God for that blessing, whereby the people of the NorthWestern Provinces have been relieved from the fear of impending famine; and the great successes recently obtained by the British arms in Afghanistan, whereby the hope of honourable and secure peace is held out to India, impose upon us all the duty of humble thanksgiving to Almighty God, through whose paternal gooduess alone these events have been brought to pass. Nor have we less incurred the duty of earnest supplication, that we may not be led to abuse these last gifts of God's bounty, or to attribute to ourselves that which is due to Him alone; but that He may have granted to us grace so to improve these gifts to us, to show ourselves worthy of His love, and fit instruments, in His hand, for the government of the great nation which His wisdom has placed under British rule.' These, surely, are sentiments worthy of a British statesman, and honourable to the Christian head of the most powerful empire in Asia ! - sentiments, embodying so solemn a recognition of Jehovah's supremacy and man's responsibility; - sentiments which are sure to be translated into all the languages, and circulated among all the nations of the Eastern world! $\mathrm{Oh}$, let all the British Churches respond, with heart and soul, to the voice of thanksgiving and supplication which is about to be lifted up by all the Churches in India! and pray that the time may come, and that right speedily, when the outpourings of God's Spirit shall descend on this dry and parched land." 


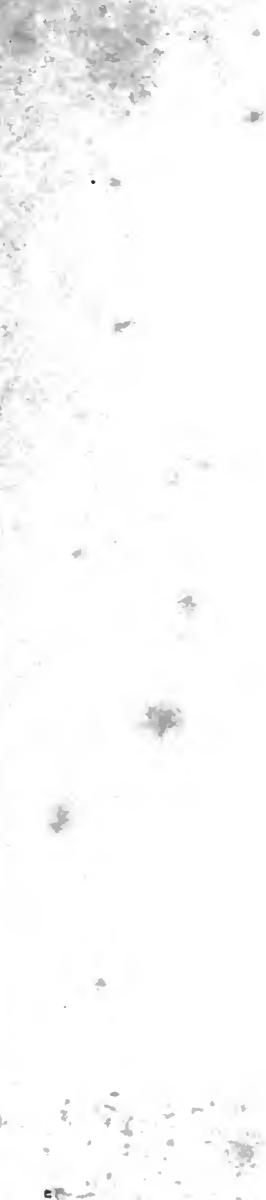

$$
\begin{aligned}
& 2, \ldots+\frac{2}{4}+4
\end{aligned}
$$

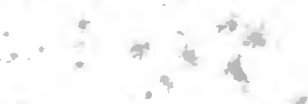

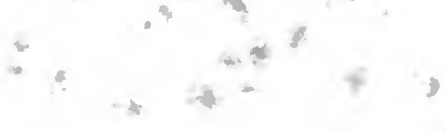

8

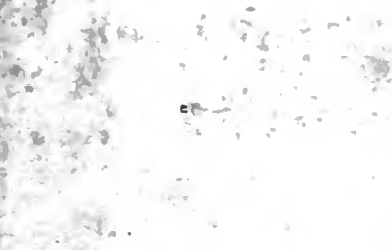

$2 \times 13$

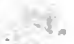

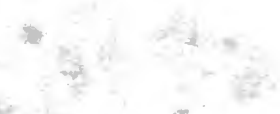





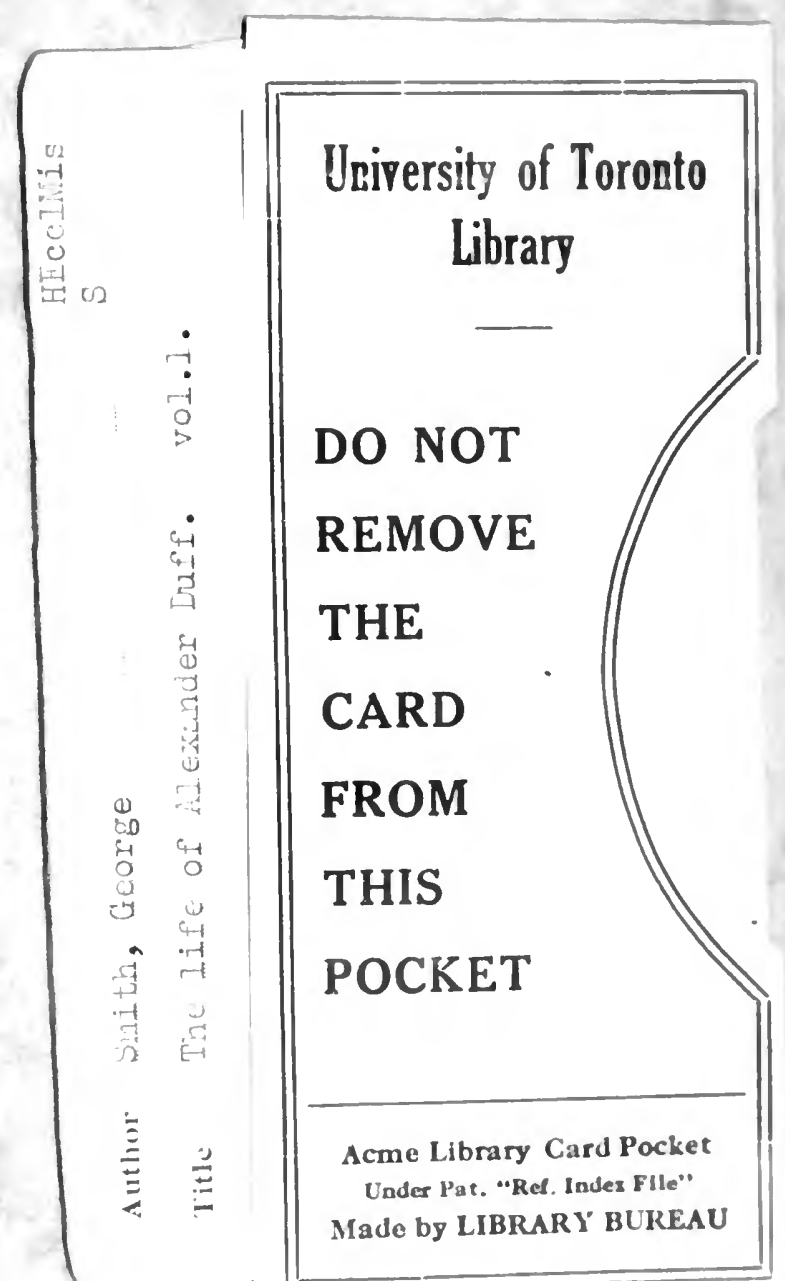


(2)

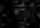

